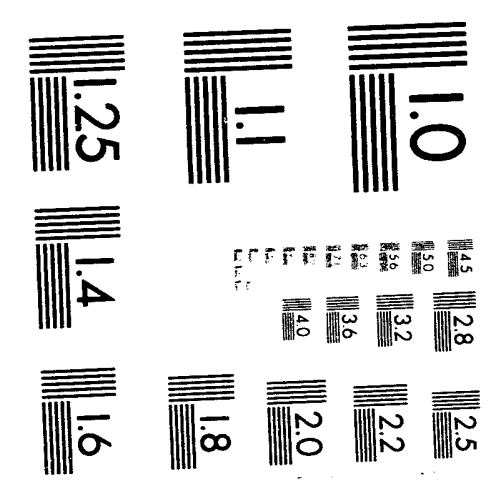



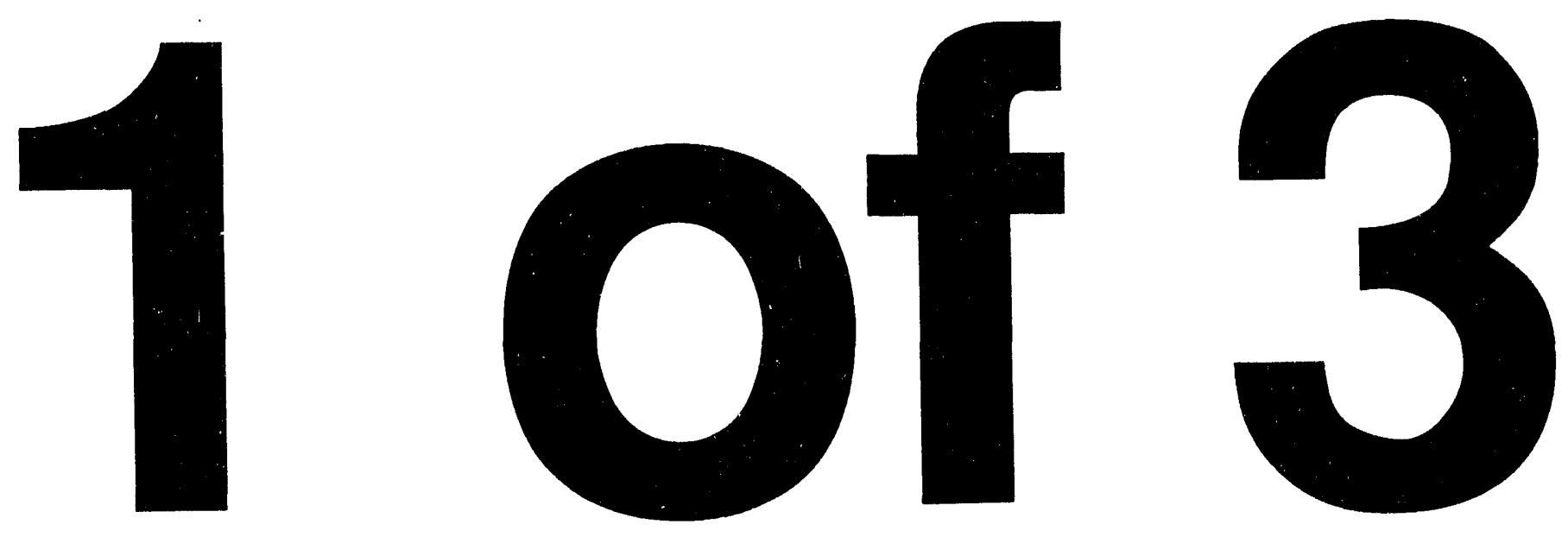


\title{
Groundwater Impact Assessment Report for the 216-S-26 Crib, 200 West Area
}

\author{
J. W. Lindberg \\ S. D. Evelo \\ D. J. Alexander \\ Date Published \\ November 1993
}

Prepared for the U.S. Department of Energy Office of Environmental Restoration and Waste Management

\section{(29) Westinghouse







Document Title: Groundwater Impact Assessment Report for the 216-S-26 Crib

Prepared by:
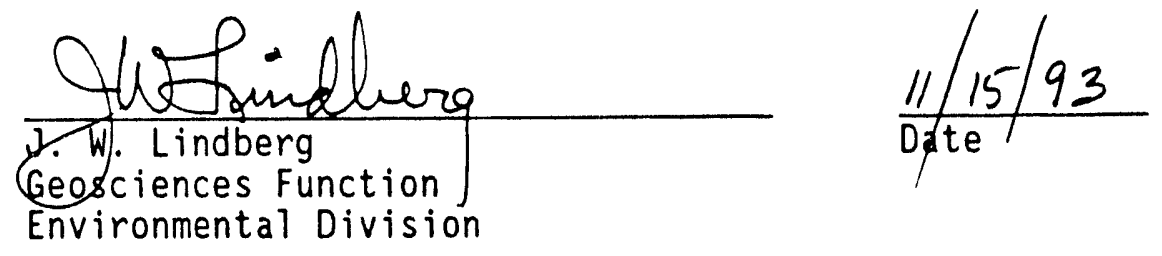

Reviewed by:

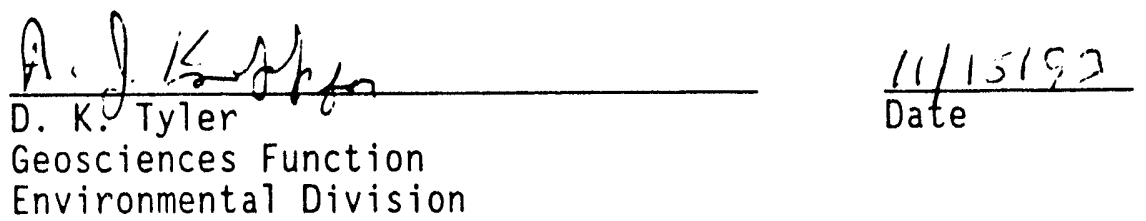

Approved by:



$$
\frac{11115 / 53}{\text { Date }}
$$

Approved by: 


\section{WHC-EP-0690}

This page intentionally left blank. 


\section{EXECUTIVE SUMMARY}

As required by the Hanford Federal Facility Agreement and Consent Order (Tri-Party Agreement Milestone M-17-00A), this report assesses the impact of wastewater discharged to the 216-S-26 Crib on groundwater quality. The assessment reported herein expands upon the initial analysis conducted between 1989 and 1990 for the Liquid Effluent Study Final Project Plan. ${ }^{2}$

\section{Facility Description}

The 216-S-26 Crib, located in the southern 200 West Area, has been in use since 1984 to dispose of liquid effluents from the 222-S Laboratory Complex. The 222-S Laboratory Complex effluent stream includes wastewater from four sources: the 222-S Laboratory, the 219-S Waste Storage Facility, the 222-SA Chemical Standards Laboratory, and the 291-S Exhaust Fan Control House and Stack. The average flow rate, as of January 1993 was $4.1 \times 10^{4} \mathrm{~L}$ /month $\left(1.1 \times 10^{4} \mathrm{gal} /\right.$ month) or $0.95 \mathrm{~L} /$ minute $(0.26 \mathrm{gal} /$ minute). Discharges to the crib are scheduled to cease by June 1995 .

\section{Impact Assessment}

Based on assessment of groundwater chemistry and flow data, contaminant transport predictions, and groundwater chemistry data, the 216-S-26 Crib has minimal influence on groundwater contamination in the southern 200 West Area. Locally, groundwater is contaminated primarily with uranium, nitrate, tritium, and chloroform, which are attributed to upgradient past-practice sources other

\footnotetext{
'Ecology, EPA, and DOE, 1990, Hanford Federal Facility Agreement and Consent Order, Washington State Department of Ecology, U.S. Environmental Protection Agency, and U.S. Department of Energy, Oiympia, Washington.

${ }^{2} W H C, 1990$, Liquid Effluent Study Final Project P7an, WHC-EP-0367, Westinghouse Hanford Company, Richland, Washington.
} 
than the 216-S-26 Crib. The most likely sources are the 216-S-1, 216-S-2, 216-S-7, 216-S-13, and 216-S-25 Cribs, which are located to the northwest of the S-26 Crib. Other potential sources are the 216-S-22 Crib and 216-S-12 Trench, 1ocated to the north of the S-26 Crib.

Constituents of interest for the 216-5-26 Crib are manganese-54, cobalt-60, cesium-137, americium-241, strontium-90, aluminum, and uranium. Calculated travel times to the water table for all constituents except uranium, were more than 40 years. Therefore, any of these constituents present in the crib would be retained in the soil column. The calculated travel time for uranium was less than five years. Selenium was identified in this report as an additional constituent of interest, because it was detected in the groundwater in elevated concentrations. Travel time to groundwater for selenium was calculated at less than a year. Selenium has not been detected in the 216-S-26 Crib effluent; however, the analytical limit of detection is currently too high to rule out the presence of selenium in the effluent. There is no conclusive evidence that the uranium and selenium present in the groundwater at the 216-S-26 Crib came from discharges to the crib. It appears more likely that the source of these constituents is upgradient of the 216-S-26 Crib.

\section{Conclusions}

Continued short-term operation of the 216-S-26 Crib will have little effect on groundwater contamination in the southern 200 West Area. The groundwater monitoring well currently installed at the 216-S-26 Crib is adequate for use of the crib, under current operating conditions (September 1993), until the June 1995 cessation date. If discharges to the 
WHC-EP-0690

216-S-26 Crib continue beyond June 1995, installation of additional groundwater monitoring wells for this site should be considered to better distinguish upgradient contaminant sources from the effects of discharge to the 216-S-26 Crib. 
WHC-EP-0690

This page intentionally left blank. 


\section{CONTENTS}

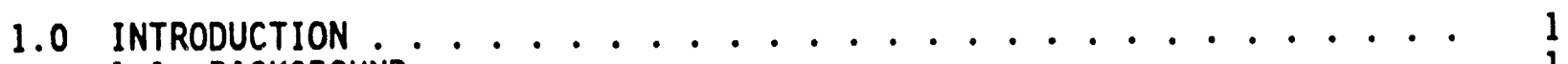

1.1 BACKGROUND $\ldots \ldots$

2.0 FACILITIES DESCRIPTION ................ 3

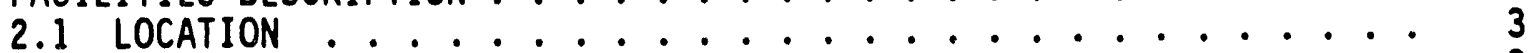

2.2 HISTORY ............................ 3

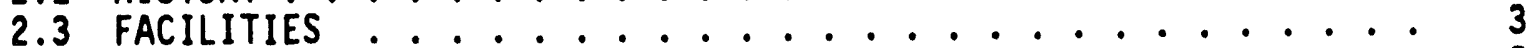

2.4 ADJACENT FACILITIES . . . . . . . . . . . . . 8

3.0 EFFLUENT CHARACTERISTICS . . . . . . . . . . . . 23

$3.1222-5$ LABORATORY ..................... 23

3.1.1 Layout and System Operation ........... 23

3.1 .2 Discharge Volume and Flow Regime .......... 24

3.1.3 Effluent Constituents ........... 24

3.1.4 Constituents of Interest and Key Indicators . . . . 37

3.2 219-S WASTE STORAGE FACILITY, 222-SA ANALYTICAL CHEMICAL

STANDARDS LABORATORY, AND 291-S EXHAUST FAN CONTROL

HOUSE AND STACK ...................... 39

3.2.1 Layout and System Operation ............ 39

3.2 .2 Discharge Volume and Flow Regime .......... 39

3.2.3 Effluent Constituents ........... 40

3.2.4 Constituents of Interest and Key Indicators . . . . 4 40

4.0 CONCEPTUAL MODEL OF HYDROLOGIC RESPONSE AND CONTAMINANT

MIGRATION . . . . . . . . . . . . . . . . 47

4.1 HYDROGEOLOGIC FRAMEWORK ............. 47

4.1.1 Regional and Hanford Site Geology . . . . . . . 47

4.1 .2 Local Geology ... . . . . . . . . . . . . 53

4.1.3 Regional and Hanford Site Hydrology ......... 55

4.1 .4 216-S-26 Crib Area Hydrology .......... 58

4.2 HYDRרLOGIC RESPONSES TO EFFLUENT DISPOSAL . . . . . . . . 59

4.3 GROUNDWATER QUALITY . . . . . . . . . . . 63

4.3.1 216-S-26 Crib Groundwater Quality ........ 63

4.3.2 Upgradient Groundwater Quality .......... 69

4.4 SOIL COLUMN CHEMISTRY FACTORS ............. 79

4.5 SUMMARY OF CONCEPTUAL MODEL ............... 84

5.0 IMPACT ASSESSMENT . . . . . . . . . . . . 87

5.1 HYDROLOGIC IMPACTS ................ 87

5.2 CONTAMINANT IMPACTS . . . . . . . . . . . . . . 87

5.2.1 Analytical Technique .......... 87

5.2.2 Results of Initial Analytical Solution ........ 91

5.2.3 Actual Field Conditions and Indications ...... 91

5.3 EVALUATION OF MONITORING NETWORK ADEQUACY ......... 99

5.3.1 Groundwater Monitoring Well Placement ........ 94

5.3.2 Reporting of Monitoring Data ........... 94 


\section{CONTENTS (cont)}

6.0 SUMMARY AND CONCLUSIONS ............................... 95

6.1 GROUNDWATER QUALITY IMPACTS .................. . . 95

6.2 HYDROLOGIC IMPACTS .................... 95

6.3 CONCLUSIONS ....................... 95

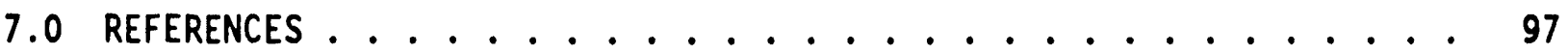

APPENDIXES:

A-1. GROUNDWATER DATA FOR WELL 299-W27-1 . ......... A1-i

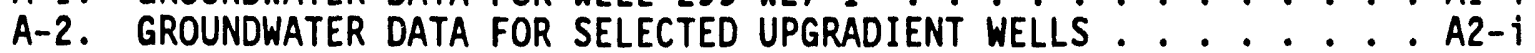

B. CHEMISTRY PLOTS ................... B-i 
WHC-EP-0690

\section{LIST OF FIGURES}

1 Location of the 222-S Laboratory and 216-S-26 Crib . . . . . . . 4

2 Site Map of the 216-S-26 Crib Showing Well Locations . . . . . . . 5

3 Location of Geologic Cross Section and Nearby Facilities . . . . . 6

4 As-Built for Well 299-W27-1, Monitoring Well for the 216-S-26 Crib...................... . . 7

5 The 222-S Laboratory and Associated Facilities . . . . . . . . . 9

6 The 222-S Laboratory Wastewater System . . . . . . . . . . . . 10

7 Location of Unplanned Releases in the Vicinity of the 216-S-26 Crib....................... 16

8 Total Volume of Effluent Discharged to the 216-S-26 Crib Through July 1993 ... . . . . . . . . . . . . . . . 27

9 Summary of the Yearly Results for (a) Gross Alpha and Gross Beta and (b) Radionuclides Released to the 216-S-26 Crib......... 38

10 Generalized Stratigraphy of the Pasco Basin and Surrounding Area ...................... 48

11 Generalized Stratigraphy of the Suprabasalt Sediments in the Pasco Basin........................ 49

12 Generalized Stratigraphic Column for the Southern 200 West Area . . . 51

13 North-Northwest to South-Southeast Geologic Cross Section Through the Southern Portion of the 200 West Area . . . . . . . . . . 54

14 Location of Water Disposal Sites on the Hanford Site . . . . . . 56

15200 Areas Water Table Elevation, June 1992 . . . . . . . . . . . 61

16 Concentration Plots of 216-S-26 Crib Effluent, Well 299-W27-1 Groundwater, and Hanford Site Background Average for the Unconfined Aquifer (Johnson 1993b) for (a) $\mathrm{pH}$ and

(b) Specific Conductance ................... 66

17 Concentration Plots of 216-S-26 Crib Effluent, Wel1 299-W27-1 Groundwater, and Hanford Site Background Average for the Unconfined Aquifer (Johnson 1993b) for (a) Nitrate and

(b) Sulfate...........................

18 Concentration Plots of 216-S-26 Crib Effluent, We11 299-W27-1 Groundwater, and Hanford Site Background Average for the Unconfined Aquifer (Johnson 1993b) for (a) Selenium and

(b) Total Uranium 


\section{LIST OF FIGURES (cont)}

19 Nitrate Plume Map for the 200 West Area . . . . . . . . . . . . 70

20 Chloroform Plume Map for the 200 West Area . . . . . . . . . . 71

21 Tritium Plume Map for the 200 West Area . . . . . . . . . . . 72

22 Griss Alpha Plume Map for the 200 West Area . . . . . . . . . . 73

23 Location of Nearby Facilities, Past-Practice Disposal Sites, and Selected Monitoring Wells in the Vicinity of the 216-S-26 Crib.................... 76

24 Concentration Plots of Nitrate in (a) 216-S-26 Crib Effluent, Well 299-W27-1 Groundwater, and Hanford Site Background Average for the Unconfined Aquifer (Johnson 1993b) and (b) Upgradient Monitoring Wells Near Disposal Sites in the Vicinity of the 216-S-26 Crib...............

25 Concentration Plots of Total Uranium in (a) 216-S-26 Crib Effluent, Well 299-W27-1 Groundwater, and Hanford Site Background Average for the Unconfined Aquifer (Johnson 1993b) and (b) Upgradient Monitoring Wells Near Disposal Sites in the Vicinity of the 215-S-26 crib.....................

26 Concentration Plots of Sulfate in (a) 216-S-26 Crib Effluent, Well 299-W27-1 Groundwater, and Hanford Site Background Average for the Unconfined Aquifer (Johnson 1993b) and (b) Upgradient Monitoring Wells Near Disposal Sites in the Vicinity of the 216-S-26 Crib................

27 Concentration Plots of Selenium in (a) 216-S-26 Crib Effluent, Well 299-W27-1 Groundwater, and Hanford Site Background Average for the Unconfined Aquifer (Johnson 1993b) and (b) Upgradient Monitoring Wells Near Disposal Sites in

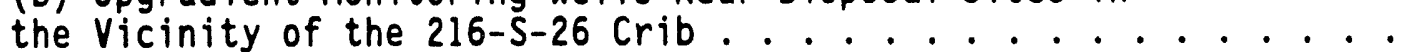

28 Concentration Plots of Vanadium in (a) 216-S-26 Crib Effluent, Well 299-W27-1 Groundwater, and Hanford Site Background Average for the Unconfined Aquifer (Johnson 1993b) and (b) Upgradient Monitoring Wells Near Disposal Sites in the Vicinity of the 216-S-26 Crib............... 82

29 Illustrated Conceptual Model for the 216-S-26 Crib . . . . . . . 85

30 Lithology of Well 299-W27-1 at 216-S-26 Crib . . . . . . . . . 89

31 Hydraulic Conductivity Versus Moisture Content . . . . . . . . . . . 90 
WHC-EP-0690

\section{LIST OF TABLES}

1 Description of Effluents Disposed of to Nearby Facilities and Past-Practice Operations . . . . . . . . . . . . . . 11

2 Summary of Unplanned Releases . . . . . . . . . . . . . . 17

3 Historical Effluent Stream Description . . . . . . . . . . . 24

4 Partial Effluent Stream Volume Description . . . . . . . . . 25

5 List of Chemicals Used in the 222-S Laboratory . . . . . . . . . 28

6 Summary of Inorganic Chemical Constituent Concentrations $(\mathrm{ppb})$ in Effluent Discharged to the 216-S-26 Crib . . . . . . . 30

7 Summary of Organic Constituent Concentrations (ppb) in Effluent Discharged to the $216-5-26 \mathrm{Crib}$............ 32

8 Summary of Physical and Radiological Constituent Concentrations ( $p p b$, except where otherwise indicated) in Effluent Discharged to the 216-S-26 Crib ..................

9 Radiological and Chemical Loading Rates for Historical Discharges to the 216-S-26 Crib ................. 35

10 222-SA Laboratory Chemical Stock . . . . . . . . . . . . . . . 41

11 Commercial Cleaners Used in the 222-SA Analytical Chemical Standards Laboratory . . . . . . . . . . . . . . . . . 46

12 Constituents Detected - Groundwater Monitoring Data for Well 299-W27-1 .................. 64

13 Potential Contamination Sources and Nearby Groundwater Monitoring Wells . . . . . . . . . . . . . . . . . 75

$14 K_{d}$ Values for Strontium-90, Cesium-137, and Plutonium-239 in Soils Treated with Various Detergents ............... 83

15 Effluent Stream Sampling Data for the 216-S-26 Crib - Key Constituents .................... . 92

16 Analytical Solution Results for the 216-S-26 Crib from the Liquid Effluent Study Final Project Report 


\section{WHC-EP-0690}

This page intentionally left blank. 


\subsection{INTRODUCTION}

Groundwater impact assessments (GIA) are required for a number of liquid effluent receiving sites according to the Hanford Federal Facility Agreement and Consent Order (Tri-Party Agreement) Milestones M-17-00A and M-17-00B, as agreed upon by the U.S. Department of Energy (DOE), Washington State Department of Ecology (Ecology), and the U.S. Environmental Protection Agency (EPA) (Ecology et a1. 1991). This report assesses the impacts to groundwater from the disposal of effluent to the $216-\mathrm{S}-26 \mathrm{Crib}$ (S-26 Crib) in the 200 West Area.

\subsection{BACKGROUND}

In response to public comments on the original Tri-Party Agreement and at the request of the signatories on the Tri-Party Agreement, the DOE, Richland Operations office (RL) assessed the impact of liquid effluents discharged to the ground at the Hanford Site (WHC 1990b, 1990C). The EPA and Ecology expressed concerns regarding uncertainties in the evaluations made by $\mathrm{RL}$. Foremost among these concerns were the lack of site-specific data, the need to consider interactions with adjacent liquid discharge facilities, and the need for more rigorous models of contaminant transport. Therefore, RL, Ecology, and EPA (the three parties) created a series of Tri-Party Agreement Milestones, including $M-17-00 A, M-17-00 B, M-17-13$, and $M-17-13 A$, which pertain to GIAs.

Tri-Party Agreement Milestones M-17-00A and M-17-00B require impact assessments for Phase I and II waste streams (Stordeur and Flyckt 1988). Effluents discharged to the S-26 Crib were defined as a Phase I waste stream. Tri-Party Agreement Milestone M-17-13 required a methodology for assessing the impact of liquid effluent discharge on groundwater, which resulted in the document, A Methodology for .1ssessing Impacts to Groundwater from Disposal of Liquid Effluent to the Soil at the Hanford Site (Tyler 1991). Thirty days after regulatory approvdl of the methodology document, as required by Tri-Party Agreement Milestone M-17-13A, a schedule for performing assessments at thirteen receiving sites was completed. The $S-26$ Crib is identified as one of the receiving sites to undergo a GIA.

\subsection{METHODOLOGY}

The methodology presented in Tyler (1991) was followed in preparing the GIA for the S-26 Crib. Tyler (1991) included the categorization of each of the 13 receiving sites into 1 of 3 levels based on the effort needed to perform the assessment. A level 1 receiving site GIA relies on available information. A level 2 receiving site GIA may rccuire nonintrusive field work to verify existing contamination. A level 3 site may require intrusive field work. If existing information is inadequate while performing a level I GIA, it may be raised to a level 2 or 3 . 
The methodology document (Tyler 1991) outlines several tasks to be conducted as part of the GIA for level l receiving sites:

- Prepare and present a plan describing how the GIA will be conducted

- Characterize the liquid effluent stream

- Evaluate the site-specific hydrogeology

- Develop a site conceptual model

- Assess the hydrologic impact of the liquid effluent stream

- Assess the contaminant impact of the liquid effluent stream

- Evaluate the adequacy of the existing monitoring well network

- Prepare a written report of the resuits.

The tasks required for level 2 and 3 receiving sites are similar to those outlined above, but also include field work-related activities. The S-26 Crib is categorized as a level 1 receiving site based on the moderate volume of liquids discharged at the site and the low loading rate of potential contaminants on the soil column (Tyler 1991).

Several key assumptions inherent to all GIAs are explained in the methodology document (Tyler 1991). For this GIA, the following assumptions are relevant.

- The expected level of impact from the receiving site determines how well the chemistry, geology, and hydrology need to be understood.

- Modeling sophistication is tailored to available information and the expected level of impact to the receiving site.

- Historical data are useable. 


\subsection{FACILITIES DESCRIPTION}

\subsection{LOCATION}

The Hanford Site is a $1,450-\mathrm{km}^{2}\left(560-\mathrm{mi}^{2}\right)$ tract of 1 and located in Benton, Franklin, and Grant Counties in the south-central portion of Washington State. The 200 West Area is located in the west-central part of the Hanford Site, approximately $37 \mathrm{~km}(23 \mathrm{mi})$ northwest of the city of Richlano (Figure 1). The S-26 Crib and the 222-S Laboratory Complex (source of the wastewater to the crib) are located in the southeast corner of the 200 West Area. The 222-S Laboratory Complex is located within the 200 West Area perimeter fence and the $S-26$ Crib is located immediately outside the fence (Figure 2). The one groundwater monitoring well (299-W27-1) associated with the S-26 Crib, is located adjacent to and on the south side of the crib (see Figure 2).

\subsection{HISTORY}

The S-26 Crib was constructed in 1984 and has been in use since then. Before 1984, wastewater from the 222-S Laboratory Complex was discharged to the 216-S-19 Pond (S-19 Pond) (Figure 3) or the 216-S-20 Crib (S-20 Crib) (see Figures 2 and 3 ). From 1952 to 1973, discharges were to both $S-19$ Pond and S-20 Crib. From 1973 to 1984 , only the S-19 Pond was used. Well 299-W27-1 was drilled and completed in 1984 (DOE-RL 1992). Figure 4 shows the well construction and completion summary.

\subsection{FACILITIES}

The S-26 Crib receives wastewater from the 222-S Laboratory Complex. The 222-S Laboratory provides analytical services to the 200 Areas operations analyzing nonradioactive and radioactive samples. The $222-5$ Laboratory supports efforts to characterize the waste stored in the 200 Areas singleshell tanks. In addition, analytical services are provided for the following waste management processing facilities:

- Tank Farms

- B Plant

- 242-A Evaporator Facility

- Plutonium-Uranium Extraction Plant

- Plutonium Finishing Plant (PFP)

- Uranium-0xide Plant

- Waste Encapsulation Storage Facility

- Environmental monitoring and surveillance programs

- Activities involving essential materials, research, and development.

Information about the S-26 Crib and the sources of wastewater to the crib is taken from the 222-S Laboratory Sampling and Analysis Plan (Warwick 1992) for wastewater that comes from the 222-S Laboratory Complex and discharges to 
Figure 1. Location of the 222-S Laboratory and 216-S-26 Crib.



H9306010.23 
WHC-EP-0690

Figure 2. Site Map of the 216-S-26 Crib Showing Well Locations.
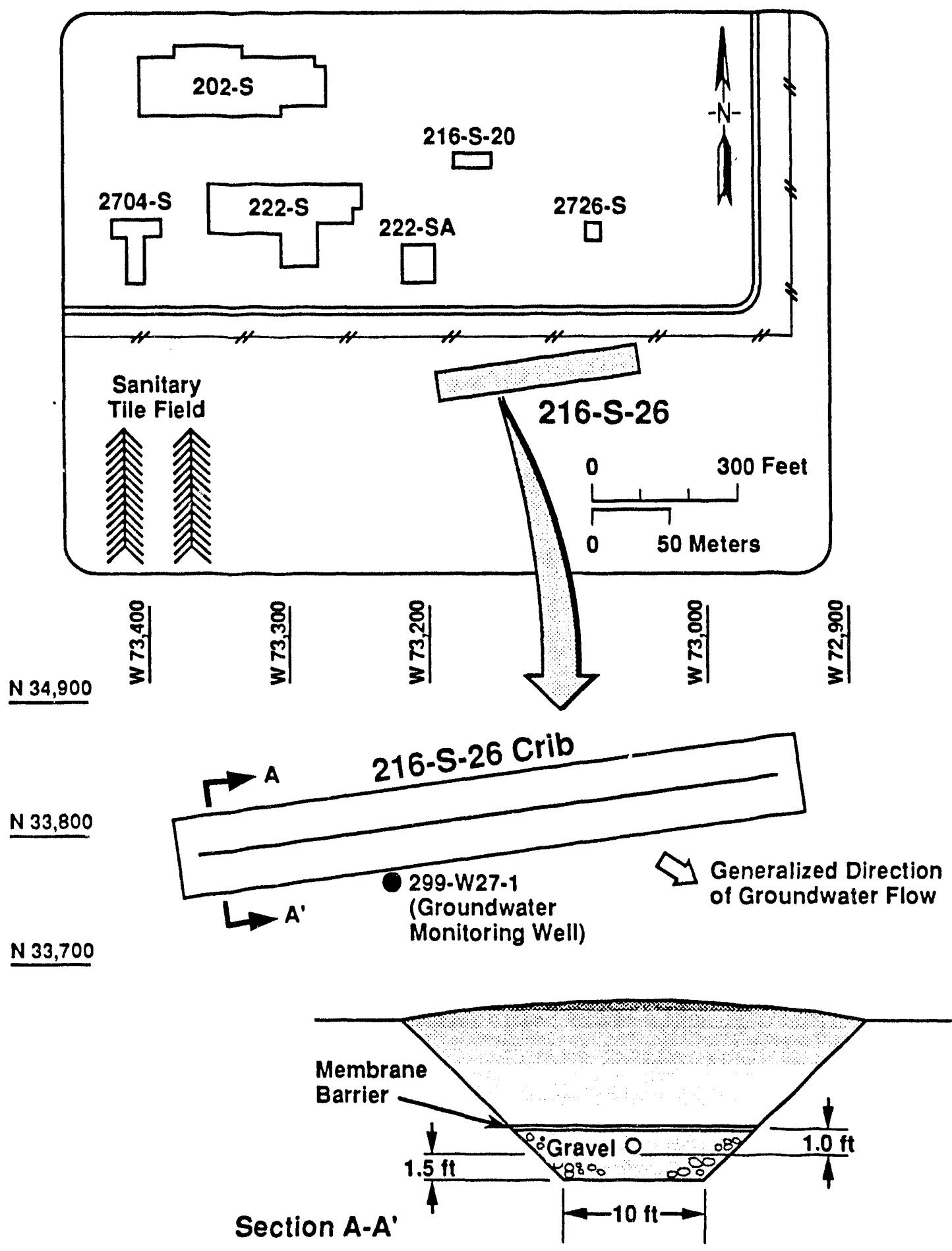

H9305023.1 
Figure 3. Location of Geologic Cross Section and Nearby Facilities.



JWLIM060893-C 
Figure 4. As-Built for Well 299-W27-1, Monitoring Well for the 216-S-26 Crib.

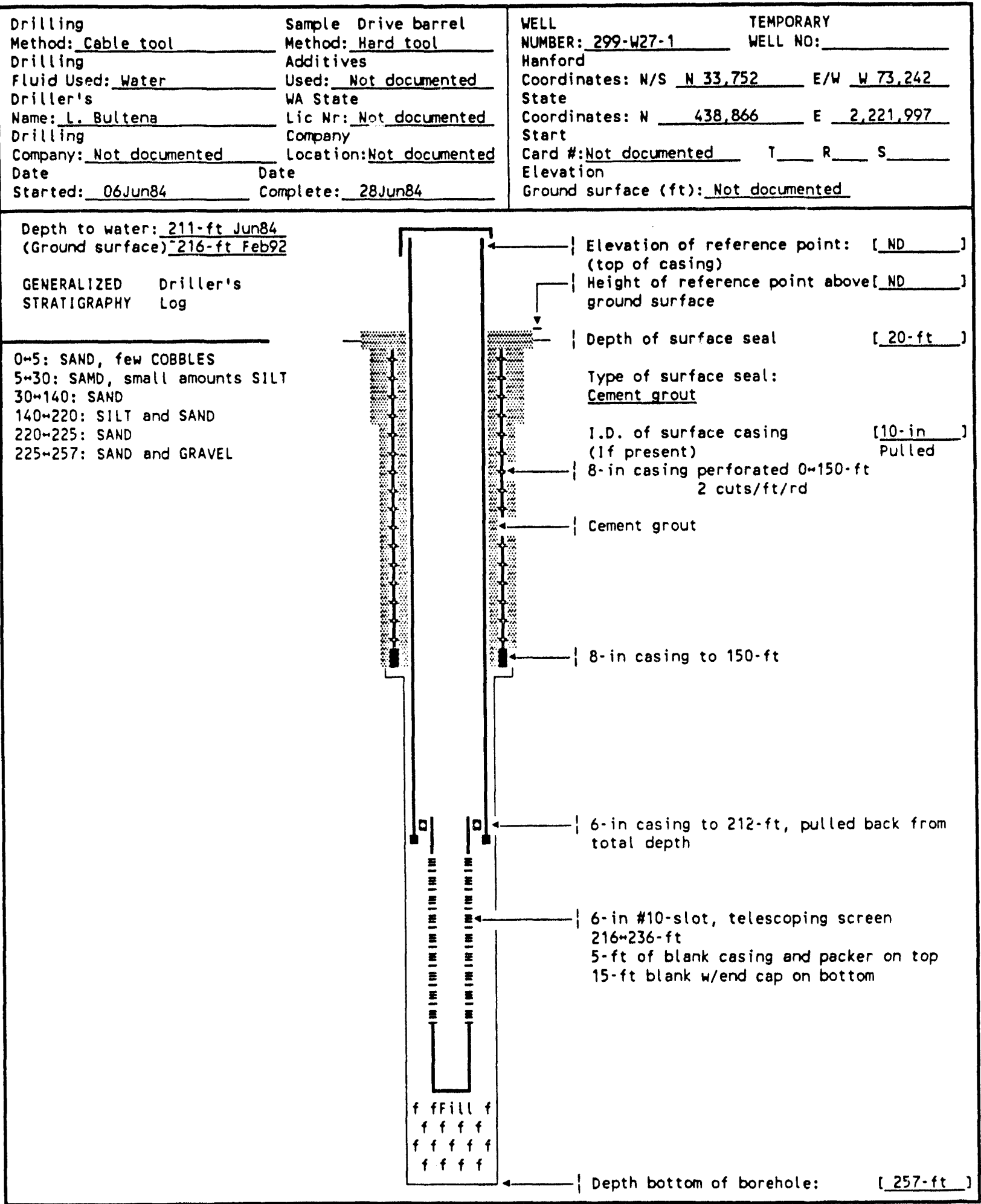


the S-26 Crib. Information about the waste stream, such as flow rates and effluent constituents, is from the waste stream-specific report (Hall 1990).

The S-26 Crib is 128 by $3 \mathrm{~m}$ ( 420 by $10 \mathrm{ft}$ ). A 15-cm $(0.5-\mathrm{ft}$ ) vitrified clay, perforated distribution pipe runs the length of the crib, $0.5 \mathrm{~m}(1.5 \mathrm{ft})$ above the bottom (see Figure 2). Lining the bottom of the $\mathrm{S}-26 \mathrm{Crib}$ is $0.75 \mathrm{~m}$ $(2.5 \mathrm{ft})$ of gravel covered with a membrane barrier and $2.9 \mathrm{~m}(9.5 \mathrm{ft})$ of earth. One gage well with a liquid-level indicator is located $30.5 \mathrm{~m}$ (100 ft) from the west end of the crib, and a vent riser is located at the east end. The S-26 Crib accommodates up to $283,905 \mathrm{~L} /$ day $(75,000 \mathrm{gal} /$ day $)$, or $94,635 \mathrm{~L} / 8$ hours $(25,000$ gal/8 hours) per shift.

Wastewater that is discharged to the S-26 Crib comes from one or more of four sources (Figure 5):

- 222-S Laboratory

- 219-S Waste Storage Facility

- 222-SA Analytical Chemical Standards Laboratory

- 291-S Exhaust Fan Control House and Stack.

Wastewater from the 222-S Laboratory Complex and the 219-S Waste Storage Facility first goes to the 207-SL Retention Basin (Figure 6). The wastewater is held until it is sampled and analyzed and determined to comply with WHC-CM-7-5, Environmental Compliance (WHC 1988). If the wastewater meets compliance requirements (WHC 1988), it is sent to the $S-26 \mathrm{Crib}$. Batches of effluent held that are not in compliance with radioactive and mixed-waste release criteria are pumped to the 219-S Waste Handling Facility for transfer to underground storage tanks. Batches of effluent held that are not in compliance with pH or total organic carbon (TOC) requirements are handled on a case-by-case basis; batches with too high or low of a pH value are neutralized before being sent to the S-26 Crib and batches that exceed the TOC requirements are sent to the underground storage tanks as described above.

The 207-SL Retention Basin consists of two 94,635-L (25,000-gal) belowgrade compartments. Samples of the retention basin wastewater used to determine disposal requirements are collected automatically as the effluent enters the basin (see Figure 6 ). If the samples meet release criteria, the effluent can be discharged to the S-26 Crib.

Wastewater from the 222-SA Standards Laboratory and 291-S Stack Fan House is not sent to the 207-SL Retention Basin, but goes straight to the S-26 Crib (see Figure 6 ). Wastewater from these two sources is nonradioactive and nonhazardous because the facilities have never contained radioactive materials and hazardous materials are administratively controlled.

\subsection{ADJACENT FACILITIES}

Several other facilities are located nearby (see Figure 3 ) that have discharged wastewater to the ground in the past. Descriptions of liquid effluents associated with nearby facilities and past-practice operations are summarized in Table 1. Discharges contained radioactive as well as hazardous contaminants. Although some of these discharges contained contamination, most 
WHC-EP-0690

Figure 5. The 222-S Laboratory and Associated Facilities.

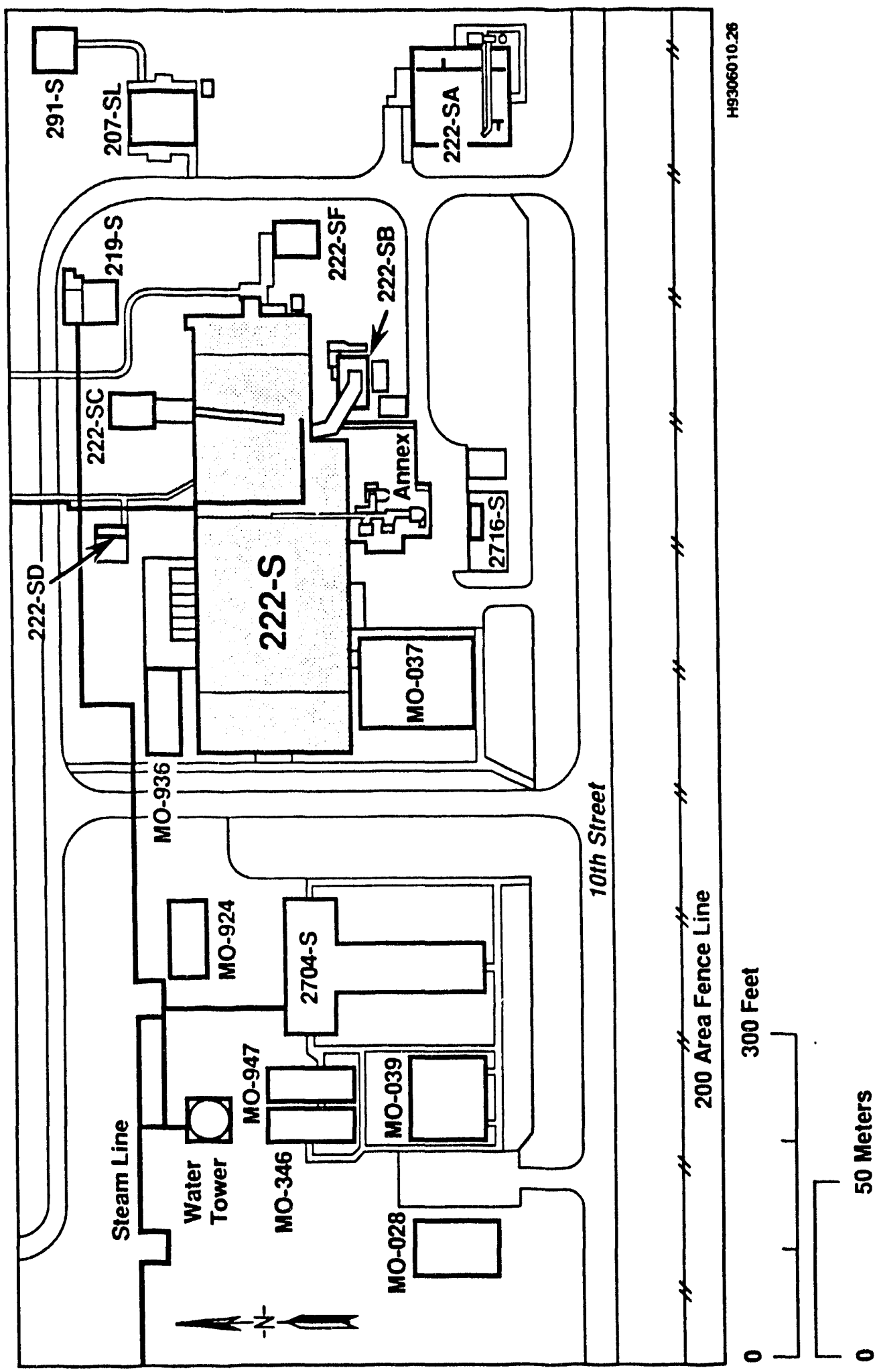


Figure 6. The 222-S Laboratory Wastewater System.

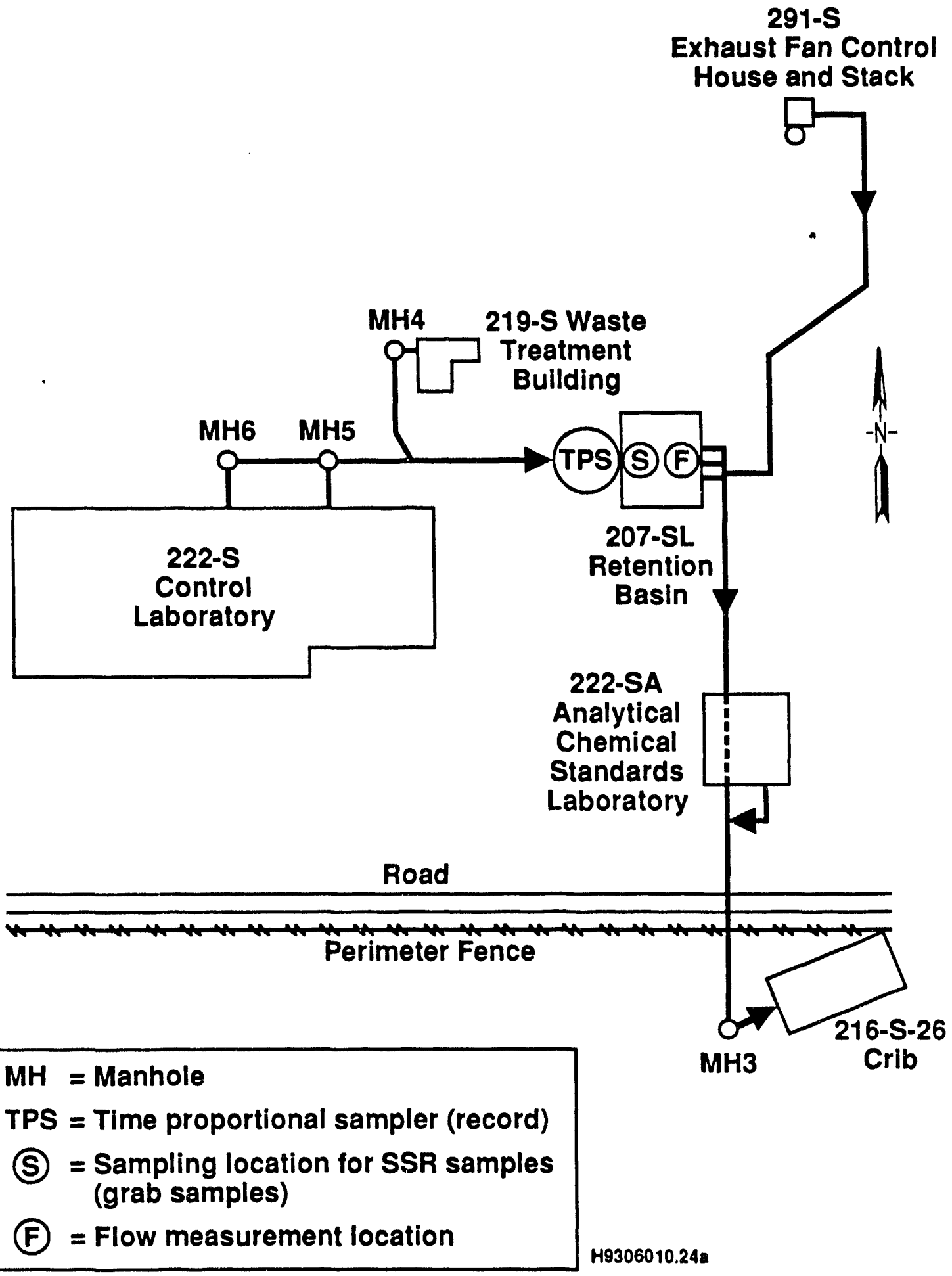


Table 1. Description of Effluents Disposed of to Nearby Facilities and Past-Practice Operations.

(4 sheets)

\begin{tabular}{|c|c|c|c|}
\hline $\begin{array}{c}\text { Facility } \\
\text { (current status) }\end{array}$ & Years of service & $\begin{array}{c}\text { Description of facility } \\
\text { (waste description, if available) }\end{array}$ & Volume received \\
\hline $\begin{array}{l}216-S-1 \text { and } \\
216-S-2 \text { Cribs } \\
\text { (inactive and } \\
\text { stabilized) }\end{array}$ & 1952 to 1956 & $\begin{array}{l}\text { Received cell drainage waste from the } \\
D-1 \text { Receiver Tank and redistilled } \\
\text { condensate from the D-2 Receiver Tank in } \\
\text { the } 202-5 \text { Building (wastes were } \\
\text { radioactive and slight acidic) }\end{array}$ & $\begin{array}{c}1.6 \mathrm{E}+08 \mathrm{~L} \\
(4.2 \mathrm{E}+08 \mathrm{gal})\end{array}$ \\
\hline $\begin{array}{l}216-\mathrm{S}-7 \text { Crib } \\
\text { (inactive and } \\
\text { stabilized) }\end{array}$ & 1956 to 1965 & $\begin{array}{l}\text { Received cell drainage from the } \\
D-1 \text { Receiver Tank, process condensate } \\
\text { from the D-2 Receiver Tank, and } \\
\text { condensate from the } H-6 \text { Condenser in the } \\
202-S \text { Building }\end{array}$ & $\begin{array}{c}3.9 \mathrm{E}+08 \mathrm{~L} \\
(1.0 \mathrm{E}+08 \mathrm{gal})\end{array}$ \\
\hline $\begin{array}{l}216-S-9 \text { Crib } \\
\text { (inactive and } \\
\text { stabilized) }\end{array}$ & 1965 to 1969 & $\begin{array}{l}\text { Received process condensate from the } \\
\text { D-2 Receiver Tank in the 202-S Building } \\
\text { (primarily nitric acid/radioactive waste) }\end{array}$ & $\begin{array}{c}5.03 \mathrm{E}+07 \mathrm{~L} \\
(1.33 \mathrm{E}+07 \mathrm{gal})\end{array}$ \\
\hline \multirow[t]{2}{*}{$\begin{array}{l}216-S-13 \text { Crib } \\
\text { (inactive and } \\
\text { stabilized) }\end{array}$} & 1952 to 1967 & $\begin{array}{l}\text { Received liquid waste from the } \\
203-S \text { Decontaminated Metal Storage } \\
\text { Facility, the 204-S Uranyl Nitrate } \\
\text { Hexahydrate Facility, and the } \\
\text { 276-S Organic Solvent Make-Up Facility }\end{array}$ & \multirow[t]{2}{*}{$\begin{array}{c}5.0 \mathrm{E}+06 \mathrm{~L} \\
(1.3 \mathrm{E}+06 \mathrm{gal})\end{array}$} \\
\hline & 1967 to 1972 & $\begin{array}{l}\text { Received occasional sump waste from the } \\
204-S \text { Uranyl Nitrate Hexahydrate Facility } \\
\text { (waste was low salt; neutral/basic; and } \\
\text { mainly composed of nitrate, sodium, and } \\
\text { sodium dichromate) }\end{array}$ & \\
\hline
\end{tabular}


Table 1. Description of Effluents Disposed of to Nearby Facilities and Past-Practice Operations.

(4 sheets)

\begin{tabular}{|c|c|c|c|}
\hline Facility & Years of service & $\begin{array}{c}\text { Description of facility } \\
\text { (waste description, if available) }\end{array}$ & Volume received \\
\hline \multirow[t]{6}{*}{$\begin{array}{l}216-S-20 \text { Crib } \\
\text { (inactive and } \\
\text { stabilized) }\end{array}$} & 1952 to 1953 & $\begin{array}{l}\text { Received miscellaneous waste from } \\
\text { laboratory hoods and decontamination } \\
\text { sinks in the S Plant via the } \\
219-S \text { Retention Basin }\end{array}$ & \multirow[t]{3}{*}{$\begin{array}{c}1.35 \mathrm{E}+08 \mathrm{~L} \\
(3.57 \mathrm{E}+07 \mathrm{gal})\end{array}$} \\
\hline & \multirow[t]{2}{*}{1953 to 1963} & $\begin{array}{l}\text { Received same effluent as above except } \\
\text { via pipelines from the 207-SL Retention } \\
\text { Basin and 219-S Retention Basin }\end{array}$ & \\
\hline & & 300 Area lab waste via tanker truck & \\
\hline & 1963 to 1969 & $\begin{array}{l}\text { Received miscellaneous waste from } \\
\text { laboratory hoods and decontamination } \\
\text { sinks in the } 222-S \text { Laboratory via the } \\
219-5 \text { Retention Basin; } 300 \text { Area lab } \\
\text { wastes were rerouted to } 216-T-28 \text { Crib }\end{array}$ & \multirow[t]{3}{*}{$\begin{array}{c}1.35 \mathrm{E}+08 \mathrm{~L} \\
(3.57 \mathrm{E}+07 \mathrm{gal})\end{array}$} \\
\hline & 1969 to 1972 & $\begin{array}{l}\text { Crib was inactive because the ground } \\
\text { caved in above the crib }\end{array}$ & \\
\hline & 1972 to 1973 & Crib stabilized and sinkholes filled in & \\
\hline $\begin{array}{l}216-S-22 \text { Crib } \\
\text { (inactive and } \\
\text { stabilized) }\end{array}$ & 1957 to 1967 & $\begin{array}{l}\text { Received liquid waste from the acid } \\
\text { recovery facility in the } 293-5 \text { Building } \\
\text { (contained nitrate and sodium) }\end{array}$ & $\begin{array}{c}9.84 \mathrm{E}+04 \mathrm{~L} \\
(2.6 \mathrm{E}+04 \mathrm{gal})\end{array}$ \\
\hline \multirow[t]{2}{*}{$\begin{array}{l}\text { 216-S-25 Crib } \\
\text { (active) }\end{array}$} & 1973 to 1980 & $\begin{array}{l}\text { Received 242-S Evaporator process steam } \\
\text { cundensate through November } 1980\end{array}$ & \multirow[t]{2}{*}{$\begin{array}{c}3.0 \mathrm{E}+08 \mathrm{~L} \\
(8.0 \mathrm{E}+07 \mathrm{gal})\end{array}$} \\
\hline & 1980 to present & $\begin{array}{l}\text { Received 241-SX Tank Farm cooling water; } \\
242-S \text { Evaporator in standby mode }\end{array}$ & \\
\hline
\end{tabular}


Table 1. Description of Effluents Disposed of to Nearby Facilities and Past-Practice Operations.

(4 sheets)

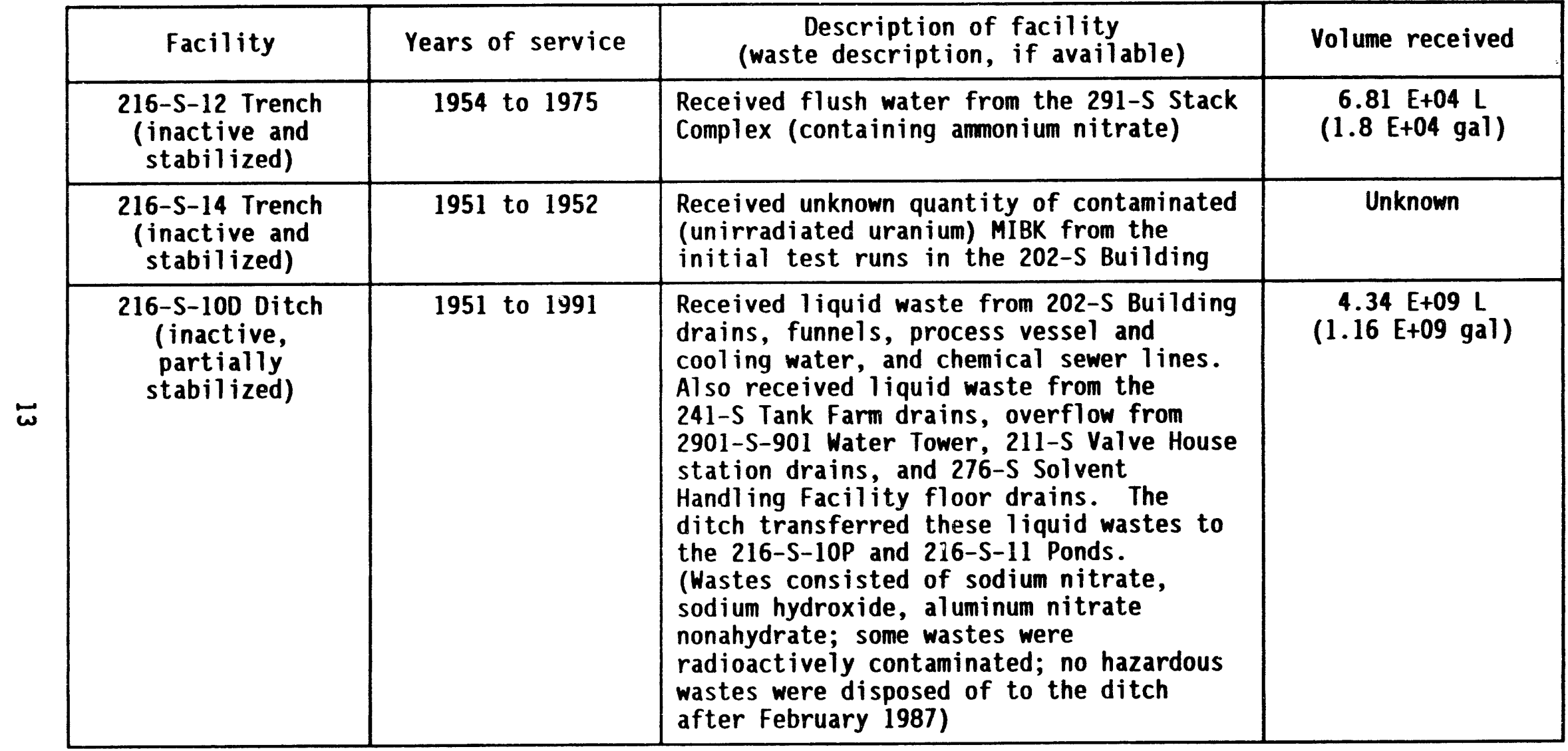


Table 1. Description of Effluents Disposed of to Nearby Facilities and Past-Practice Operations.

(4 sheets)

\begin{tabular}{|c|c|c|c|}
\hline Facility & Years of service & $\begin{array}{l}\text { Description of facility } \\
\text { (waste description, if available) }\end{array}$ & Volume received \\
\hline \multirow[t]{3}{*}{$\begin{array}{l}216-S-19 \text { Pond } \\
\text { (inactive and } \\
\text { stabilized) }\end{array}$} & 1952 to 1954 & $\begin{array}{l}\text { Received effluent from the } \\
222-S \text { Laboratory ventilation cooling } \\
\text { water and miscellaneous wastes from } \\
\text { laboratory hoods and decontamination pond } \\
\text { via the 207-SL Retention Basin }\end{array}$ & \multirow[t]{3}{*}{$\begin{array}{c}1.33 \mathrm{E}+09 \mathrm{~L} \\
(3.51 \mathrm{E}+08 \mathrm{gal})\end{array}$} \\
\hline & 1954 to 1955 & $\begin{array}{l}\text { Pond inactive because radionuclide } \\
\text { concentration in the } 207-S L \text { Retention } \\
\text { Basin liquid wastes was above the } \\
\text { prescribed disposal guidelines; wastes } \\
\text { rerouted to the } 216-5-20 \text { Crib }\end{array}$ & \\
\hline & 1955 to 1984 & $\begin{array}{l}\text { Received cooling water and miscellaneous } \\
\text { wastes from laboratory hoods and } \\
\text { decontamination sinks in the } \\
222-5 \text { Laboratory }\end{array}$ & \\
\hline $\begin{array}{l}\text { 2607-W6 Septic Tank } \\
\text { and Drain Field }\end{array}$ & 1951 to present & Receives sanitary wastewater and sewage & $\begin{array}{c}3.48 E+04 \mathrm{~L} / \text { day } \\
(9.2 \mathrm{E}+03 \mathrm{gal} / \mathrm{day})\end{array}$ \\
\hline $\begin{array}{l}\text { 2607-WZ Septic Tank } \\
\text { and Drain Field }\end{array}$ & 1944 to present & Receives sanitary wastewater and sewage & $\begin{array}{c}2.26 \mathrm{E}+04 \mathrm{~L} / \text { day } \\
(5.97 \mathrm{E}+03 \mathrm{gal} / \mathrm{day})\end{array}$ \\
\hline
\end{tabular}

NOTE: Stabilized $=$ Clean fill and/or cover added to surface of facility.

MIBK = Methyl isobutyl ketone. 
of the wastewater was uncontaminated process condensate. All other discharge sources were terminated by the time the S-26 Crib was put into service in 1984, except for the septic tanks and associated drain fields.

Unplanned releases that contained varying amounts of radioactive contamination, as well as intentional discharges, have al so occurred near the $\mathrm{S}-26 \mathrm{Crib}$ and the 222-S Laboratory Complex. Figure 7 shows the locations of these unplanned releases (DOE-RL 1992). Only the releases that occurred in the vicinity of the S-26 Crib are discussed in this document (Table 2). 


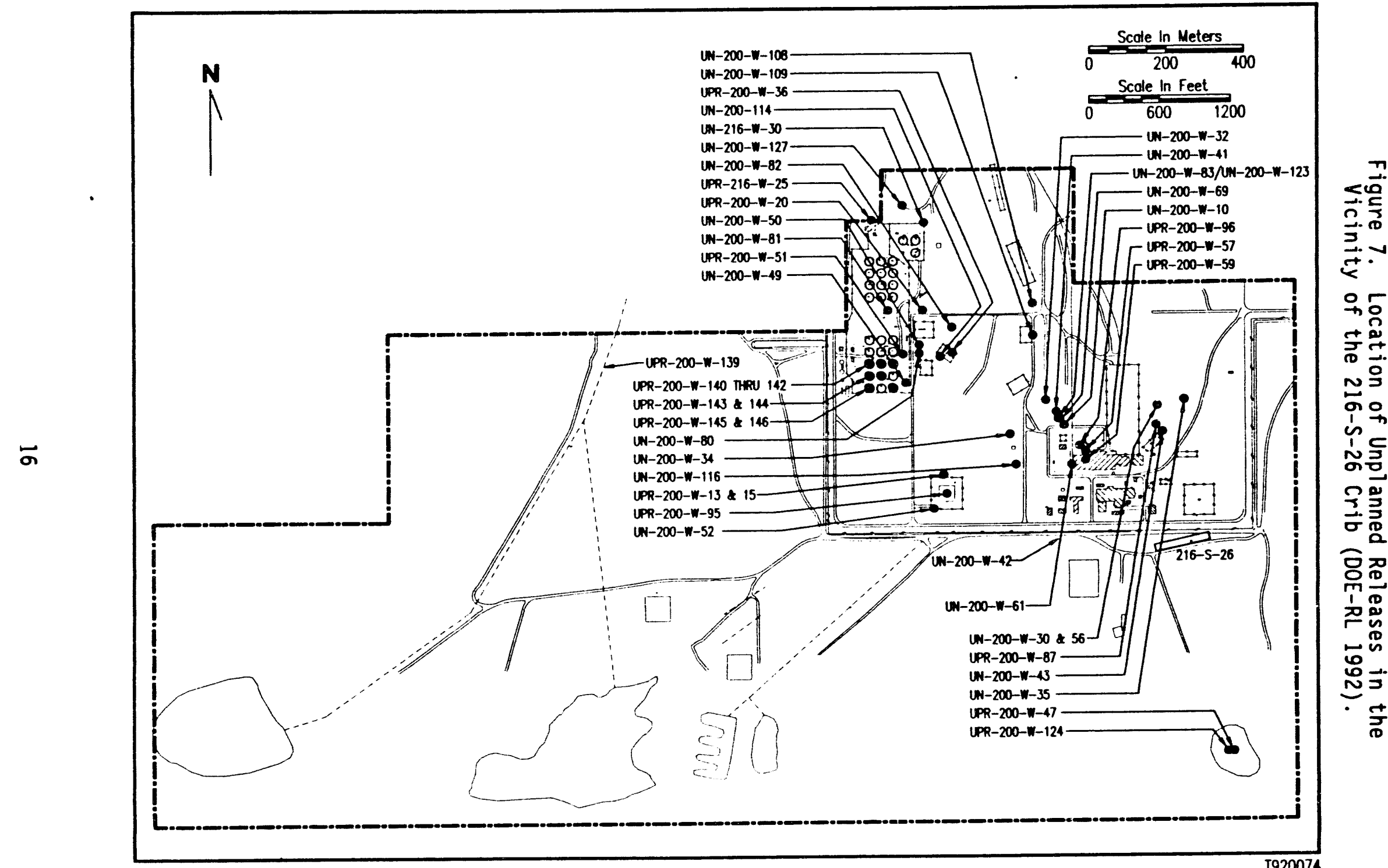

종
1
1
0
0
0
0
0 
Table 2. Summary of Unplanned Releases (DOE-RL 1992). (5 sheets)

\begin{tabular}{|c|c|c|c|c|}
\hline $\begin{array}{l}\text { Unpl amned } \\
\text { release no. }\end{array}$ & Location & Date & $\begin{array}{l}\text { Associated waste } \\
\text { management unit }\end{array}$ & Reported waste - reloted history \\
\hline \multirow[t]{3}{*}{ UN-200-W-10 } & \multirow{3}{*}{$\begin{array}{l}\text { Near the } \\
203-s \text { Uranium } \\
\text { Storage Tanks }\end{array}$} & \multirow[t]{3}{*}{1952} & \multirow[t]{3}{*}{ MA } & An unknown source caused spotty uranium contaminotion. \\
\hline & & & & Maximum readings of $10,000 \mathrm{ct} / \mathrm{min}$ at $2 \mathrm{~cm}(1 \mathrm{in}$.) were noted. \\
\hline & & & & $\begin{array}{l}\text { The contaminated area was covered with asphalt and posted with } \\
\text { raciation zone signs. }\end{array}$ \\
\hline \multirow[t]{3}{*}{ UW-200-W-30 } & \multirow[t]{3}{*}{ 216-s-12 Trench } & \multirow[t]{3}{*}{$7 / 54$} & \multirow[t]{3}{*}{$216-5-12$ Trench } & $\begin{array}{l}\text { The contaminated area was limited to a pit near the northeast } \\
\text { corner of the S Plant stack. The pit was covered with several } \\
\text { feet of clean soil. }\end{array}$ \\
\hline & & & & $\begin{array}{l}\text { Contamination consisted predominantly of ruthenium and zircon/ } \\
\text { niobium with approximately } 5 \mathrm{Ci} \text { of beta activity and } 2 \text { to } 3 \mathrm{Ci} \text { of } \\
\text { gamma activity. }\end{array}$ \\
\hline & & & & $\begin{array}{l}\text { This site is scheduled for deletion; it is a duplicate of the } \\
216-5-12 \text { Trench. }\end{array}$ \\
\hline \multirow[t]{3}{*}{$u w-200-w-32$} & \multirow{3}{*}{$\begin{array}{l}\text { Near the northwest } \\
\text { corner of S Plant } \\
\text { exclusion area }\end{array}$} & \multirow[t]{3}{*}{1954} & \multirow[t]{3}{*}{ MA } & $\begin{array}{l}\text { A ruptured transfer line from } 224-U \text { to } S \text { plant spilled uranyl } \\
\text { nitrate hexahydrate solution to the ground. }\end{array}$ \\
\hline & & & & $\begin{array}{l}\text { No analytical data were provided on the level of contemination } \\
\text { associated with this release. }\end{array}$ \\
\hline & & & & $\begin{array}{l}\text { The conteminated area was covered with clean soil and the site } \\
\text { removed from radiation zone status in February } 1971 \text {. }\end{array}$ \\
\hline \multirow[t]{3}{*}{$U N-200-4-34$} & \multirow[t]{3}{*}{$\begin{array}{l}\text { An area between the } \\
\text { open ditch and the } \\
\text { 202-s Chemical Sewer } \\
\text { Trenches }\end{array}$} & \multirow[t]{3}{*}{$5 / 55$} & \multirow[t]{3}{*}{ MA } & $\begin{array}{l}\text { Release involved overflow from an open ditch and the } \\
\text { 202-s chemical Sewer Irenches, resulting in contamination of } \\
\text { opproximately. } 5,000 \mathrm{~m}^{2}\left(53,821 \mathrm{ft}^{2}\right) \text { between the open ditith and } \\
\text { the trenches. }\end{array}$ \\
\hline & & & & Maximum exposure rate of $1 \mathrm{R} / \mathrm{hour}$ was recorded. \\
\hline & & & & $\begin{array}{l}\text { The ditch was dredged and the sludge removed, placed in low spots } \\
\text { on both sides of the ditch, and covered with } 0.6 \mathrm{~m}(2 \mathrm{ft}) \text { of } \\
\text { soil. The area was removed from rodiation zone status in March } \\
1971 \text {. }\end{array}$ \\
\hline \multirow[t]{2}{*}{$U N-200-W-35$} & \multirow{2}{*}{$\begin{array}{l}\text { Outside and north of } \\
\text { S Plant exclusion } \\
\text { ores }\end{array}$} & \multirow[t]{2}{*}{$9 / 55$} & \multirow[t]{2}{*}{ ma } & $\begin{array}{l}\text { Release from a leak in the uramyl nitrate hexahydrate process } \\
\text { line from S Plant to U Plont. }\end{array}$ \\
\hline & & & & $\begin{array}{l}\text { Contamination was removed to the } 200 \text { Hest Area Bur ial Ground. } \\
\text { The area was removed from rediation zone status in Jamuary } 1972 \text {. }\end{array}$ \\
\hline
\end{tabular}


Tabie 2. Summary of Unplanned Releases (DOE-RL 1992). (5 sheets)

\begin{tabular}{|c|c|c|c|c|}
\hline $\begin{array}{l}\text { Unplanned } \\
\text { release no. }\end{array}$ & Locition & Date & $\begin{array}{l}\text { Associated waste } \\
\text { management unit }\end{array}$ & Reported waste - reloted history \\
\hline \multirow[t]{3}{*}{ UN-200-N-41 } & \multirow{3}{*}{$\begin{array}{l}\text { Right-of-way from } \\
\text { the 202-s Building } \\
\text { reil rod cut to the } \\
\text { buriol ground }\end{array}$} & \multirow[t]{3}{*}{$7 / 7 / 56$} & \multirow[t]{3}{*}{ NA } & $\begin{array}{l}\text { Transport of a burial box caused ground contenination at the } \\
\text { right-of-way from the 202-s Building railroed cut to the burial } \\
\text { ground. }\end{array}$ \\
\hline & & & & $\begin{array}{l}\text { Unknown beta/gamma emitter with readings to } 1,000 \mathrm{mrad} / \text { hour } \\
\text { recorded. }\end{array}$ \\
\hline & & & & Remedial actions not identified. \\
\hline \multirow[t]{3}{*}{$U N-200-4-42$} & \multirow{3}{*}{$\begin{array}{l}\text { Ground around a } \\
\text { raitroad shack near } \\
202-5 \text { Building }\end{array}$} & \multirow[t]{3}{*}{$2 / 3 / 57$} & \multirow[t]{3}{*}{ MA } & $\begin{array}{l}\text { Contaminated spots from on unknown source were found in the } \\
\text { S Plant Aggregate Area near a rail rood shack. }\end{array}$ \\
\hline & & & & $\begin{array}{l}\text { Contamination consisted of unknown beta/gamme readings to } \\
500 \mathrm{mrad} / \mathrm{hour} \text {. }\end{array}$ \\
\hline & & & & $\begin{array}{l}\text { The site was cleaned and readings were reduced from } 2,000 \text { to } \\
5,000 \mathrm{ct} / \mathrm{min} \text {. }\end{array}$ \\
\hline \multirow[t]{3}{*}{$U N-200-W-43$} & \multirow[t]{3}{*}{$\begin{array}{l}\text { Blacktop area near } \\
\text { radiation zone east } \\
\text { of } 223-5 \text { Building }\end{array}$} & \multirow[t]{3}{*}{$2 / 12 / 57$} & \multirow[t]{3}{*}{ MA } & $\begin{array}{l}\text { Site originated from windolown contanination from a neasby } \\
\text { radiation zone. Site is opproximotely } 110 \mathrm{~m}^{2}\left(1,200 \mathrm{ft}^{2}\right) \text { with } \\
4,500 \mathrm{~kg}(5 \text { tons) of contaminated soit. }\end{array}$ \\
\hline & & & & Unknown alpha emitter with readings to $2,000 \mathrm{dis} / \mathrm{min}$. \\
\hline & & & & Remedial octions not identified. \\
\hline UN-200-U-52 & $\begin{array}{l}\text { South of the } \\
241-5-151 \text { Diversion } \\
\text { Box toward } \\
\text { 10th Street }\end{array}$ & $9 / 15 / 58$ & $\begin{array}{l}\text { 207-s Retention Basin } \\
\text { and } 241-5-151 \\
\text { Diversion Box }\end{array}$ & $\begin{array}{l}\text { Leakage from the } 241-5-151 \text { Diversion Box caused ground } \\
\text { contamination in an oval-shaped area approximately } 91 \mathrm{~m}(300 \mathrm{ft}) \\
\text { wide, Iying immediutely south of the diversion box toward } \\
10 t h \text { street, including the } 207-\mathrm{s} \text { Retention Basin. }\end{array}$ \\
\hline \multirow[t]{3}{*}{ UN-200-W-56 } & \multirow[t]{3}{*}{$\begin{array}{l}\text { Wear the } \\
202-s \text { Colum Carrier } \\
\text { Trench }\end{array}$} & \multirow[t]{3}{*}{$2 / 6 / 61$} & \multirow[t]{3}{*}{ MA } & $\begin{array}{l}\text { Heavy rainfall washed contamination from }{ }^{2} \text { radiation zone } \\
(216-\mathrm{s}-12) \text { and } \mathrm{j}^{2} \text { ontaminated } 19 \mathrm{~m}^{2}\left(200 \mathrm{ft}^{2}\right) \text { of graveled surface } \\
\text { and } 5 \mathrm{~m}^{2}\left(50 \mathrm{ft}^{2}\right) \text { of blacktop. }\end{array}$ \\
\hline & & & & $\begin{array}{l}\text { Unknown beta/gamme emitter readings of } 30,000 \mathrm{ct} / \mathrm{min} \text { on graveled } \\
\text { surface and } 80,000 \mathrm{ct} / \mathrm{min} \text { on the blacktop were recorded. }\end{array}$ \\
\hline & & & & The contaminated area was roped off (at that time). \\
\hline
\end{tabular}


Table 2. Summary of Unplanned Releases (DOE-RL 1992). (5 sheets)

\begin{tabular}{|c|c|c|c|c|}
\hline $\begin{array}{l}\text { Unplanned } \\
\text { release no. }\end{array}$ & Location & Date & $\begin{array}{l}\text { Associated waste } \\
\text { management unit }\end{array}$ & Reported waste - related history \\
\hline \multirow[t]{3}{*}{$U N-200-4-61$} & \multirow[t]{3}{*}{$\begin{array}{l}\text { Wear the southwest } \\
\text { corner of the } \\
202-\mathrm{s} \text { Building }\end{array}$} & \multirow[t]{3}{*}{$4 / 24 / 66$} & \multirow[t]{3}{*}{ MA } & $\begin{array}{l}\text { A firehose ruptured while flushing the } H-10 \text { Receiver Tonk to the } \\
241 \text {-Sx transfer lige, resulting in contaninat ion of on area } \\
\text { approximately } 19 \mathrm{~m}^{2}\left(200 \mathrm{ft}^{2}\right) \text { and containing } 9.000 \mathrm{~kg}(10 \text { tons }) \\
\text { of soil. }\end{array}$ \\
\hline & & & & $\begin{array}{l}\text { Unknown beta/game emitter resdings from } 4.000 \text { to } 100,000 \mathrm{ct} / \mathrm{min} \\
\text { were recorded. }\end{array}$ \\
\hline & & & & $\begin{array}{l}\text { Contaminated walkways were washed doun and released from } \\
\text { radiation zone status. The top } 15 \mathrm{~cm}(6 \text { in.) of conteminated } \\
\text { soil were removed. }\end{array}$ \\
\hline \multirow[t]{4}{*}{ UN-200-W-69 } & \multirow[t]{4}{*}{$\begin{array}{l}\text { Between the } \\
204-s \text { Building } \\
\text { rail rood spur and } \\
\text { the S Plant railroad } \\
\text { cut }\end{array}$} & \multirow[t]{4}{*}{$3 / 2 / 73$} & \multirow[t]{4}{*}{ MA } & 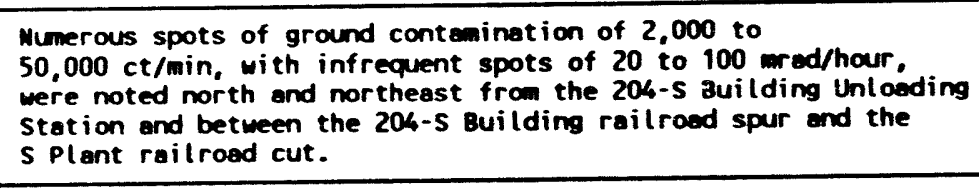 \\
\hline & & & & $\begin{array}{l}\text { Inside established radiation zone, the sump pit was found to be } \\
\text { contaminated, with readings from } 1,000 \text { to } 5,000 \text { mrad/hour and } \\
\text { the grat ing from the sump (stacked nearby) had readings of } \\
800 \text { mrad/hour. }\end{array}$ \\
\hline & & & & $\begin{array}{l}\text { Extension of survey outside } \mathrm{S} \text { Plent exclusion fence produced } \\
\text { readings of } 5,000 \text { to } 100,000 \mathrm{ct} / \mathrm{min} \text { between the } 204-\mathrm{s} \text { Building } \\
\text { rail rood spur and the } \mathrm{S} \text { plant rail roed cut enbenkment. }\end{array}$ \\
\hline & & & & Remedial actions not identified. \\
\hline$U N-200-W-83$ & $\begin{array}{l}\text { Vicinity of } \\
204-5 \text { Building } \\
\text { radiation zone }\end{array}$ & $11 / 23 / 81$ & MA & $\begin{array}{l}\text { An unknown amount of radioactive contanination was spilled on } \\
\text { the ground in the vicinity of the } 204-5 \text { suilding radiation zone. }\end{array}$ \\
\hline
\end{tabular}


Table 2. Summary of Unplanned Releases (DOE-RL 1992). (5 sheets)

\begin{tabular}{|c|c|c|c|c|}
\hline $\begin{array}{l}\text { Unpl amned } \\
\text { release no. }\end{array}$ & Locetion & Date & $\begin{array}{l}\text { Associated waste } \\
\text { management unit }\end{array}$ & Reported waste - related history \\
\hline \multirow[t]{4}{*}{$U W-200-W-108$} & \multirow{4}{*}{$\begin{array}{l}\text { Underground crib } \\
\text { waste line between } \\
216-5-9 \text { Crib and } \\
216-\mathrm{s}-23 \mathrm{Crib}\end{array}$} & \multirow[t]{4}{*}{ 1/8/69 } & \multirow[t]{4}{*}{ MA } & $\begin{array}{l}\text { Ruptures in underground crib waste lines produced unknown beta/ } \\
\text { garma emitters with exposure rates of } 40 \text { R/hour detected at the } \\
\text { bot tom of the waste line. }\end{array}$ \\
\hline & & & & $\begin{array}{l}\text { Leakage occurred over an unknown time period releasing on } \\
\text { unknown quentity of waste. }\end{array}$ \\
\hline & & & & $\begin{array}{l}\text { Release was cleaned up by redirecting approximately } 110 \mathrm{~L} \\
\text { (30 gal) of waste solution into a hole in the ground belou the } \\
\text { opening of the line and approximately } 6 \text { (20 ft) Selow ground } \\
\text { surface. }\end{array}$ \\
\hline & & & & $\begin{array}{l}\text { Amual surface radiological monitoring is performed at this } \\
\text { site; during the October } 1990 \text { survey, no contamination was } \\
\text { detected. This was a decrease from the previous survey. }\end{array}$ \\
\hline \multirow[t]{3}{*}{$U M-200-H-109$} & \multirow[t]{3}{*}{$\begin{array}{l}\text { Underground crib } \\
\text { maste line between } \\
216-5-9 \mathrm{Crib} \text { and } \\
216-5-23 \mathrm{Crib}\end{array}$} & \multirow[t]{3}{*}{$1 / 24 / 69$} & \multirow[t]{3}{*}{ MA } & 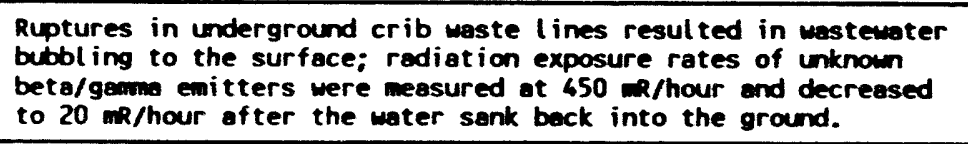 \\
\hline & & & & $\begin{array}{l}\text { Annual surface radiological monitoring is performed at the site; } \\
\text { during the october } 1990 \text { survey, general contemination wos } \\
\text { detected from } 200 \text { to } 6,000 \mathrm{ct} / \mathrm{min} \text {, indicating no change from the } \\
\text { previous survey. }\end{array}$ \\
\hline & & & & Remedial action not identified. \\
\hline \multirow[t]{2}{*}{ Uw-200-v-116 } & \multirow[t]{2}{*}{$\begin{array}{l}91 \mathrm{~m}(300 \mathrm{ft}) \text { north } \\
\text { of the } \\
202-\mathrm{s} \text { Building }\end{array}$} & \multirow[t]{2}{*}{1968} & \multirow[t]{2}{*}{ ma } & $\begin{array}{l}\text { Site was conteminated with particulate matter spread by wind } \\
\text { from the } 204-5 \text { Maste Storage Tank exhoust and the related } \\
\text { railroad tonker waste unloading station. }\end{array}$ \\
\hline & & & & $\begin{array}{l}\text { General contamination was measured at } 200 \mathrm{ct} / \mathrm{min} \text { with isolated } \\
\text { specks up to } 2 \text { mrem/hour, during surface radiation monitoring in } \\
\text { october } 1990 \text {. }\end{array}$ \\
\hline \multirow[t]{2}{*}{$U w-200-w-123$} & \multirow[t]{2}{*}{$\begin{array}{l}204-5 \text { Unloeding } \\
\text { Fecility area }\end{array}$} & \multirow[t]{2}{*}{$1 / 18 / 79$} & \multirow[t]{2}{*}{ MA } & $\begin{array}{l}\text { Release of } 73,000 \mathrm{~L}(19,300 \mathrm{gal}) \text { of radioactive liquid waste } \\
\text { occurred at the } 204-\mathrm{s} \text { Unlooding facility area, coused by a } \\
\text { frozen discharge line. }\end{array}$ \\
\hline & & & & Contaminated ground beneath the tank car was cleaned up. \\
\hline
\end{tabular}


Table 2. Summary of Unplanned Releases (DOE-RL 1992). (5 sheets)

\begin{tabular}{|c|c|c|c|c|}
\hline $\begin{array}{l}\text { Unpl anned } \\
\text { release no. }\end{array}$ & Location & Date & $\begin{array}{l}\text { Associated waste } \\
\text { management unit }\end{array}$ & Reported waste - related history \\
\hline \multirow[t]{2}{*}{ UPR-200-W-57 } & \multirow[t]{2}{*}{ 233-s Building } & \multirow[t]{2}{*}{$1 / 6 / 63$} & \multirow[t]{2}{*}{ 233-S Building } & $\begin{array}{l}\text { A fire in the plutonium colum at } 233-5 \text { Building spread } \\
\text { plutonium contamination throughout and in the immediate } \\
\text { vicinity of the building. }\end{array}$ \\
\hline & & & & $\begin{array}{l}\text { Parts of the building were cleaned of gross contemination and } \\
\text { alpha contamination was remediated. }\end{array}$ \\
\hline \multirow[t]{3}{*}{ UPR-200-W-59 } & \multirow[t]{3}{*}{$\begin{array}{l}\text { Mo. } 1 \text { Pond at } \\
202-5 \text { Building }\end{array}$} & \multirow[t]{3}{*}{$1 / 26 / 65$} & \multirow[t]{3}{*}{ 202-5 Building } & $\begin{array}{l}\text { Failure of an } F-1 \text { process vessel coil in the } 202-5 \text { Building } \\
\text { allowed effluent to mix with cool ing water. }\end{array}$ \\
\hline & & & & $\begin{array}{l}\text { Unknown bete/gama emitter readings with a maximm dose rate of } \\
190 \mathrm{mrad} / \mathrm{hour} \text { at the Mo. } 1 \text { Pond inlet. }\end{array}$ \\
\hline & & & & Remedial actions not identified. \\
\hline \multirow[t]{3}{*}{ UPR-200-W-87 } & \multirow[t]{3}{*}{$\begin{array}{l}\text { 291-S HEPA filter } \\
\text { hous ing }\end{array}$} & \multirow[t]{3}{*}{$1 / 28 / 92$} & \multirow[t]{3}{*}{ 291-s Stack Complex } & $\begin{array}{l}\text { Water leak from the } 291-5 \text { HEPA filter hous ing contaninated the } \\
\text { ground at its bese. }\end{array}$ \\
\hline & & & & Readings to $2,000 \mathrm{ct} / \mathrm{min}$ were recorded. \\
\hline & & & & Remedial actions not identified. \\
\hline \multirow[t]{3}{*}{ UPR-200-W-96 } & \multirow[t]{3}{*}{$\begin{array}{l}\text { Adjecent to and } \\
\text { north of the } \\
233-5 \text { Filter House }\end{array}$} & \multirow[t]{3}{*}{$? / 9 / 69$} & \multirow[t]{3}{*}{ MA } & $\begin{array}{l}\text { Release consisted of } 0.01 \mathrm{~g} \text { of plutonium-239-contaminated } \\
\text { water. Smear samples taken of the water and surfaces involved } \\
\text { were os follows: } \\
\text { - Water on the floor of the } 233-5 \text { filter House was greater } \\
\text { than } 40,000 \text { dis/min } \\
\text { - The concrete ped outside the filter house was } \\
10,000 \text { dis/min } \\
\text { - The electric motor ped was } 10,000 \text { dis/min } \\
\text { - The water in the overflow pool was } 600 \text { dis/min. }\end{array}$ \\
\hline & & & & The site was covered with $71 \mathrm{~m}(234 \mathrm{ft})$ of clean gravel. \\
\hline & & & & $\begin{array}{l}\text { The October } 1991 \text { radiological survey detected contamination of } \\
200 \text { to } 3,000 \mathrm{ct} / \mathrm{min} \text { at the northwest corner of the site. }\end{array}$ \\
\hline
\end{tabular}

Ci = Curie (unit of rediation).

$\mathrm{ct} / \mathrm{min}=$ Counts per minute.

dis/min $=$ Disintegrations per minute.

MEPA = Migh-efficiency particulate air.

m/hour = Milliroentgen per hour.

mrad/hour = Millirad per hour.

MA = Mot eppl icable.

R/hour $=$ Roentgen per hour .

UW = Unplanned release considered a distinct waste management unit for remediation purposes.

UPR = Unplanned releases from or within the operations of a specific waste management unit. 


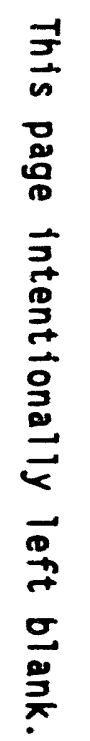

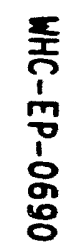




\subsection{EFFLUENT CHARACTERISTICS}

\subsection{2-S LABORATORY}

\subsubsection{Layout and System Operation}

The 222-S Laboratory is a two-story structure with a basement $98 \mathrm{~m}$ long by $33 \mathrm{~m}$ wide ( $322 \mathrm{ft}$ long by $107 \mathrm{ft}$ wide). It was built in 1950 and 1951 to provide analytical services to the Reduction Oxidation Plant. The 222-S Laboratory now supports analytical characterization of waste stored in Hanford Site single-shell tanks. It also provides services to other miscellaneous waste management processing facilities.

The first level is divided into three separate sections: the west, central, and east. The lunchroom, offices, and locker rooms are located in the west area. The west side is free of radioactive and hazardous chemicals. The central section houses chemical laboratories and service areas. Work in this section involves low- to intermediate-level radioactive wastes and hazardous chemicals. Occasionally a high-level radioactive waste sample is located within the central portion. The east side (multicurie) section contains hot cells, chemical laboratories, and service areas for work with intermediate- to high-level radioactive wastes. The central and eastern sections have laboratory benches and hood drains supplied with electricity, water, compressed air, and process vacuums. Mixed-waste (radioactive and hazardous) effluents are separated from the nonradioactive and nonhazardous effluents. All sinks, drains, distilled water supplies, equipment cooling water, and steam condensate empty into the 207-SL Retention Basin.

The second level houses the glassblowing shop, ventilation fans, ductwork, and storage areas. The ventilation fans and ductwork area are posted as radioactive surface contamination zones. The sinks and drains from the glass shop, distilled water overflow, the Millipore deionized water unit, flash tank overflow/drain lines, and the floordrain empty into the 207-SL Retention Basin. Overflow and drain lines from the nitric acid storage tank empty into a storage tank outside the 222-S Laboratory.

The basement houses the counting room, vacuum pumps, instrument maintenance shop, and the scanning electron microscope laboratory. The area is posted as a radioactive surface contamination zone. All effluent generated is analyzed for radioactivity and released to the 207-SL Retention Basin if results are below release criteria (WHC 1988).

The 222-S Laboratory has three main sources of supply water: raw, steam, and potable. The potable water is the primary source comprising $85 \%$ of the waste stream. The steam condensate supplies 15\% of the waste stream flow; raw water (used in the fire protection sprinkler system) supplies less than $1 \%$.

'Millipore is.a trademark of the Millipore Corporation. 


\subsubsection{Discharge Volume and Flow Regime}

The 222-S Laboratory began discharging wastewater effluent to the S-26 Crib in October 1984. At that time, laboratory operations discharged on the average of $25,738 \mathrm{~L}(6,800 \mathrm{gal})$ of effluent per 8 -hour shift. Table 3 describes historical effluent characteristics. The current discharge flow rate calculated from the available data (Table 4) as of the end of July 1993, is on the average of $4.1 \times 10^{4} \mathrm{~L}$ /month $\left(1.1 \times 10^{4} \mathrm{gal} /\right.$ month $)$, which works out to be $0.95 \mathrm{~L} /$ minute $(0.26 \mathrm{gal} /$ minute $)$.

Table 3. Historical Effluent Stream Description (WHC 1990C).

\begin{tabular}{|l|c|}
\hline $\begin{array}{l}\text { Total volume of effluent discharged } \\
\text { to subject receiving site (Coony and } \\
\text { Thomas 1989) }\end{array}$ & $1.51 \mathrm{E}+08 \mathrm{~L}$ from $10 / 84$ to $12 / 88$ \\
\hline $\begin{array}{l}\text { Average effluent discharge rate, by } \\
\text { operation mode (WHC 1990a) }\end{array}$ & $2.34 \mathrm{E}+06 \mathrm{~L} /$ month \\
\hline Effluent designation (WHC 1990a) & Nondangerous, radioactive \\
\hline Effluent status & Active discharge to 216-S-26 Crib \\
\hline
\end{tabular}

${ }^{\circ}$ Coony, F. M., and S. P. Thomas, 1989, Westinghouse Hanford Company Effluent Discharges and Solid Waste Management Report for Calendar Year 1988: 200/600 Areas, WHC-EP-0141-1, Westinghouse Hanford Company, Richland, Washington.

WHC, 1990a, 222-S Laboratory Wastewater Stream-Specific Report, WHC-EP-0342, Addendum 13, Westinghouse Hanford Company, Richland, Washington.

Figure 8 demonstrates that the volume of effluent discharged to the crib has decreased over the years. The volume continues to decrease as modifications are made to the 222-S Laboratory. The recent installation of a recirculating vacuum pump resulted in a $50 \%$ reduction in flow rate to the S-26 crib.

\subsubsection{Effluent Constituents}

The 222-S Laboratory generates waste that is both radiological and hazardous. Table 5 (Klem 1990) is a list of chemicals that are or were used in the laboratory. The waste includes a variety of chemicals: acetone, nitrate, nitric acid, and lesser amounts of sulfuric and hydrofluoric acids. During the week of October 20, 1984, an unnamed spill event occurred at the 222-S Laboratory, which released wastewater contaminated with strontium-90 to the 207-SL Retention Basin. The concentration of strontium-90 did not exceed the DOE Administrative Control Limit $(40 \mathrm{pCi} / \mathrm{L})$, therefore, the wastewater was released to the S-26 Crib (DOE-RL 1992). Tables 6 through 8 summarize the effluent data available from 1985 to 1990 (WHC 1990a, Addendum 13). The tables provide an average value for each constituent per year. They also indicate that only aluminum and iron have exceeded the Washington Water Quality Standard (WWQS), WAC 173-200. Table 9 provides radiological and 
Table 4. Partial Effluent Stream Volume Description (1993). (2 sheets)

\begin{tabular}{|c|c|c|c|}
\hline Date & Volume (gal) & Volume (L) & $\begin{array}{c}\text { Average volume } \\
(L)\end{array}$ \\
\hline $1 / 1 / 93$ & 12,300 & $4.7 E+04$ & \multirow[t]{24}{*}{$4.7 E+04$} \\
\hline $1 / 2 / 93$ & 11,400 & $4.3 E+04$ & \\
\hline $1 / 3 / 93$ & 15,600 & $5.9 E+04$ & \\
\hline $1 / 4 / 93$ & 16,200 & $6.1 E+04$ & \\
\hline $1 / 5 / 93$ & 12,300 & $4.7 E+04$ & \\
\hline $1 / 6 / 93$ & 12,300 & $4.7 E+04$ & \\
\hline $1 / 7 / 93$ & 15,600 & $5.9 E+04$ & \\
\hline $1 / 8 / 93$ & 12,800 & $4.8 E+04$ & \\
\hline $1 / 10 / 93$ & 9,800 & $3.7 E+04$ & \\
\hline $1 / 10 / 93$ & 11,700 & $4.4 E+04$ & \\
\hline $1 / 11 / 93$ & 15,600 & $5.9 E+04$ & \\
\hline $1 / 12 / 93$ & 16,200 & $6.1 E+04$ & \\
\hline $1 / 13 / 93$ & 12,300 & $4.7 E+04$ & \\
\hline $1 / 14 / 93$ & 12,000 & $4.5 E+04$ & \\
\hline $1 / 15 / 93$ & 11,700 & $4.4 E+04$ & \\
\hline $1 / 16 / 93$ & 11,700 & $4.4 E+04$ & \\
\hline $1 / 18 / 93$ & 11,700 & $4.4 E+04$ & \\
\hline $1 / 19 / 93$ & 10,600 & $4.0 E+04$ & \\
\hline $1 / 20 / 93$ & 8,900 & $3.4 E+04$ & \\
\hline $1 / 22 / 93$ & 10,000 & $3.8 E+04$ & \\
\hline $1 / 23 / 93$ & 12,300 & $4.7 E+04$ & \\
\hline $1 / 26 / 93$ & 10,600 & $4.0 E+04$ & \\
\hline $1 / 29 / 93$ & 11,700 & $4.4 E+04$ & \\
\hline $1 / 31 / 93$ & 10,000 & $3.8 E+04$ & \\
\hline $5 / 3 / 93$ & 10,600 & $4.0 E+04$ & \multirow[t]{3}{*}{$3.9 E+04$} \\
\hline $5 / 7 / 93$ & 10,600 & $4.0 E+04$ & \\
\hline $5 / 29 / 93$ & 10,000 & $3.8 E+04$ & \\
\hline
\end{tabular}


Table 4. Partial Effluent Stream Volume Description (1993). (2 sheets)

\begin{tabular}{|c|c|c|c|}
\hline Date & Volume (gal) & Volume (L) & $\begin{array}{c}\text { Average volume } \\
\text { (L) }\end{array}$ \\
\hline $6 / 3 / 93$ & 10,600 & $4.0 E+04$ & \multirow[t]{10}{*}{$4.0 E+04$} \\
\hline $6 / 7 / 93$ & 11,200 & $4.2 E+04$ & \\
\hline $6 / 10 / 93$ & 11,200 & $4.2 E+04$ & \\
\hline $6 / 13 / 93$ & 10,900 & $4.1 E+04$ & \\
\hline $6 / 17 / 93$ & 9,500 & $3.6 E+04$ & \\
\hline $6 / 19 / 93$ & 11,700 & $4.4 E+04$ & \\
\hline $6 / 21 / 93$ & 10,300 & $3.9 E+04$ & \\
\hline $6 / 22 / 93$ & 10,600 & $4.0 E+04$ & \\
\hline $6 / 24 / 93$ & 10,600 & $4.0 E+04$ & \\
\hline $6 / 30 / 93$ & 10,000 & $3.8 E+04$ & \\
\hline $7 / 8 / 93$ & 11,200 & $4.2 E+04$ & \multirow[t]{5}{*}{$3.7 E+D 4$} \\
\hline $7 / 12 / 93$ & 10,000 & $3.8 E+04$ & \\
\hline $7 / 16 / 93$ & 8,900 & $3.3 E+04$ & \\
\hline $7 / 22 / 93$ & 9,500 & $3.6 E+04$ & \\
\hline $7 / 28 / 93$ & 9,500 & $3.6 E+04$ & \\
\hline Total & 480,000 & $1.8 E+06$ & -- \\
\hline
\end{tabular}

Note: Information obtained from 222-S Laboratory datasheets. 


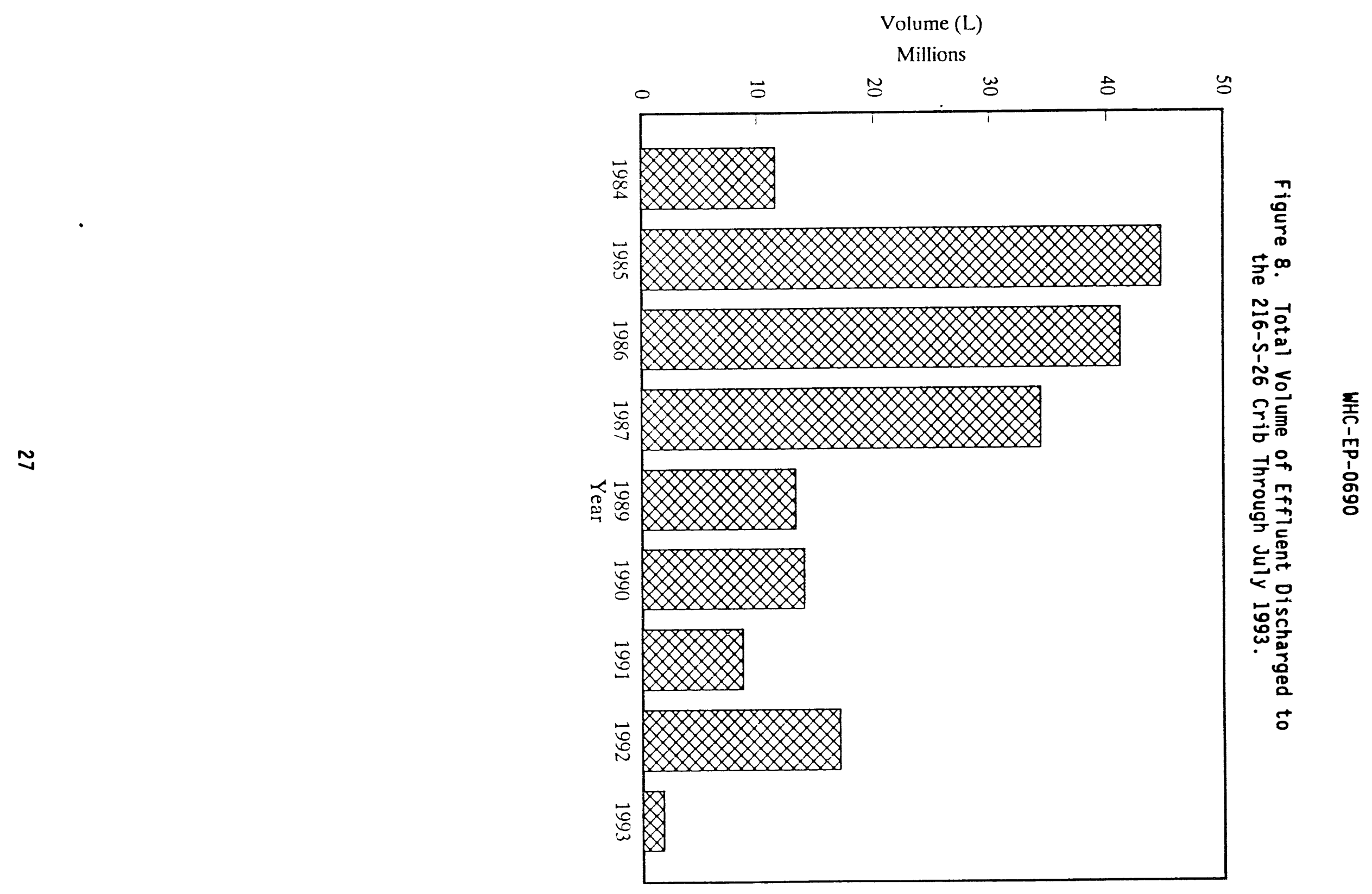


Table 5. List of Chemicals Used in the 222-S Laboratory (adapted from DOE-RL 1992). (2 sheets)

\begin{tabular}{|c|c|}
\hline Compound name & Chemical formula \\
\hline Acetone & $\mathrm{CH}_{3} \mathrm{C}_{2} \mathrm{OH}_{3}$ \\
\hline Aluminum nitrate nonahydrate & $\mathrm{Al}\left(\mathrm{NO}_{3}\right) \cdot 9 \mathrm{H}_{2} \mathrm{O}$ \\
\hline Ammonium hydroxide & $\mathrm{NH}_{4} \mathrm{OH}$ \\
\hline Ammonium oxalate & $\left(\mathrm{NH}_{4}\right)_{2} \mathrm{C}_{2} \mathrm{O}_{4} \mathrm{H}_{2} \mathrm{O}$ \\
\hline Bromonaphthalene & $\mathrm{C}_{10} \mathrm{H}_{7} \mathrm{Br}$ \\
\hline Butylated hydroxytoluene & 2,6-di-tert-buty1-4-methylphenol \\
\hline Ceric sulfate & $\mathrm{Ce}(\mathrm{SO})_{2}$ \\
\hline Di-2-ethyl hexyl phosphoric acid & $\mathrm{C}_{16} \mathrm{H}_{34} \mathrm{POOH}$ \\
\hline Ferrous sulfamate & $\mathrm{Fe}\left(\mathrm{SO}_{3} \mathrm{NH}_{2}\right)_{2}$ \\
\hline Ferrous sulfate & $\mathrm{FeSO}_{4}$ \\
\hline Hydrazine & $\mathrm{H}_{2} \mathrm{NNH}_{2} \cdot \mathrm{H}_{2} \mathrm{O}$ \\
\hline Hydrochloric acid & $\mathrm{HCl}$ \\
\hline Hydroxylamine hydrochloride & $\mathrm{NH}_{2} \mathrm{OH} \cdot \mathrm{HCl}$ \\
\hline Hydroxyquinoline & $\mathrm{C}_{9} \mathrm{H}_{6} \mathrm{NOH}$ \\
\hline Lead nitrate & $\mathrm{Pb}\left(\mathrm{NO}_{3}\right)_{2}$ \\
\hline Mercuric thiocyanate & $\mathrm{Hg}(\mathrm{SCN})_{2}$ \\
\hline Methyl ethyl ketone & $\mathrm{CH}_{3} \mathrm{COC}_{2} \mathrm{H}_{5}$ \\
\hline Methyl isobutyl ketone & $\mathrm{CH}_{3} \mathrm{COC}_{4} \mathrm{H}_{9}$ \\
\hline Mineral oil & Light hydrocarbons \\
\hline Nitrate & $\mathrm{NO}_{3}$ \\
\hline Nitric acid & $\mathrm{HNO}_{3}$ \\
\hline $\begin{array}{l}\text { Normal paraffin hydrocarbon } \\
\text { (kerosene) }\end{array}$ & $\mathrm{C}_{10} \mathrm{H}_{22}$ to $\mathrm{C}_{14} \mathrm{H}_{30}$ \\
\hline 0-phenanthroline & $\mathrm{C}_{12} \mathrm{H}_{8} \mathrm{~N}_{2}$ \\
\hline Potassium fluoride & KF \\
\hline Potassium oxalate & $\mathrm{K}_{2} \mathrm{C}_{2} \mathrm{O}_{4}$ \\
\hline Potassium permanganate & $\mathrm{KMnO}_{4}$ \\
\hline S-diphenyl carbazide & $\mathrm{C}_{13} \mathrm{H}_{14} \mathrm{~N}_{4} \mathrm{O}$ \\
\hline Sodium dichromate & $\mathrm{Na}_{2} \mathrm{Cr}_{2} \mathrm{O}_{7} \cdot 2 \mathrm{H}_{2} \mathrm{O}$ \\
\hline
\end{tabular}


Table 5. List of Chemicals Used in the 222-S Laboratory (adapted from DOE-RL 1992). (2 sheets)

\begin{tabular}{|l|l|}
\hline \multicolumn{1}{|c|}{ Compound name } & \multicolumn{1}{c|}{ Chemical formula } \\
\hline Sodium fluoride & $\mathrm{NaF}$ \\
\hline Sodium hydroxide & $\mathrm{NaOH}$ \\
\hline Sodium nitrite & $\mathrm{NaNO}_{2}$ \\
\hline Sulfate & $\mathrm{SO}_{3}$ \\
\hline Sulfuric acid & $\mathrm{H}_{2} \mathrm{SO}_{4}$ \\
\hline Tetrabromomethane & $\left(\mathrm{CHBr}_{2}\right)_{2}$ \\
\hline Tetraphenyl boron & $\left(\mathrm{C}_{6} \mathrm{H}_{5}\right) \mathrm{B}$ \\
\hline Thenoyltrifluoroacetone & $\mathrm{C}_{7} \mathrm{H}_{5} \mathrm{SO}_{2} \mathrm{~F}_{3}$ \\
\hline Tributyl phosphate & $\left(\mathrm{C}_{4} \mathrm{H}_{9}\right)_{3} \mathrm{PO}_{4}$ \\
\hline Trichloromethane (chloroform) & $\mathrm{CHCl}_{3}$ \\
\hline Titanium chloride & $\mathrm{TiCl}_{4}$ \\
\hline Tri-iso-octylamine & $\mathrm{C}_{24} \mathrm{H}_{5} \mathrm{~N}$ \\
\hline Vanadium & $\mathrm{V}$ \\
\hline Xylene & $\mathrm{C}_{6} \mathrm{H}_{4}\left(\mathrm{CH}_{3}\right)_{2}$ \\
\hline Zinc amalgam & $\mathrm{ZnHg}$ \\
\hline
\end{tabular}

Note: Source of original table (Klem 1990). 
Table 6. Summary of Inorganic Chemical Constituent Concentrations (ppb) in Effluent Discharged to the 216-S-26 Crib

(WHC 1990a, Addendum 13). (2 sheets)

\begin{tabular}{|c|c|c|c|c|c|c|}
\hline Constituent & 1985 & 1986 & 1987 & 1988 & 1989 & 1990 \\
\hline Aluminum & 300 & $1,300^{\circ}$ & $<150$ & $<150$ & $<150$ & $<150$ \\
\hline $\begin{array}{l}\text { Arsenic } \\
\text { (EP toxic) }\end{array}$ & - & -- & -- & -- & $<150$ & $<500$ \\
\hline Barium & 32 & 30 & 24 & 23 & 24 & 25 \\
\hline $\begin{array}{l}\text { Barium } \\
\text { (EP toxic) }\end{array}$ & - & - & - & - & $470^{\circ}$ & $<1,000$ \\
\hline Beryllium & $<5$ & $<5$ & $<5$ & $5^{8}$ & $<5$ & $<5$ \\
\hline Boron & - & -- & -- & -- & $12^{\circ}$ & 23 \\
\hline Cadmium & $<2$ & $<2$ & $<2$ & $2^{8}$ & $<2$ & $<2$ \\
\hline $\begin{array}{l}\text { Cadmium } \\
\text { (EP toxic) }\end{array}$ & - & -- & -- & -- & $41^{8}$ & $<100$ \\
\hline Calcium & 18,000 & 18,000 & 17,000 & 17,000 & 17,000 & 16,000 \\
\hline Chloride & 2,200 & 13,000 & 2,000 & 2,000 & 2,300 & 2,200 \\
\hline Chromium & 11 & $16^{8}$ & $<10$ & $<10$ & $<10$ & $<10$ \\
\hline $\begin{array}{l}\text { Chromium } \\
\text { (EP toxic) }\end{array}$ & -- & -- & -- & -- & $<200$ & $<500$ \\
\hline Copper & 120 & 62 & 200 & 130 & 160 & 170 \\
\hline $\begin{array}{l}\text { Fluoride } \\
\text { (IC) }\end{array}$ & $<500$ & $<500$ & $<500$ & $<500$ & $<500$ & $<500$ \\
\hline $\begin{array}{l}\text { Fluoride } \\
\text { (ISE) }\end{array}$ & - & -- & -- & 220 & 130 & 100 \\
\hline Iron & 630 & 180 & 56 & 70 & 100 & 130 \\
\hline $\begin{array}{l}\text { Lead } \\
\text { (EP toxic) }\end{array}$ & -- & -- & -- & -- & $<200^{\circ}$ & $<500$ \\
\hline Magnesium & 3,800 & 4,100 & 3,900 & 3,600 & 4,000 & 3,800 \\
\hline Manganese & 20 & 12 & 5 & $6^{\circ}$ & $6^{\circ}$ & $<5$ \\
\hline Mercury & 0.1 & $1.3^{\mathrm{a}}$ & 0.1 & $0.1^{\circ}$ & $<0.1$ & $<0.1$ \\
\hline Nickel & $<10$ & $<11$ & $<10$ & $<10$ & $<10$ & $<10$ \\
\hline Nitrate & 630 & $1,100^{\circ}$ & 1,600 & $970^{\circ}$ & $680^{\circ}$ & 800 \\
\hline Potassium & 960 & 990 & 1,100 & 680 & 720 & 660 \\
\hline
\end{tabular}




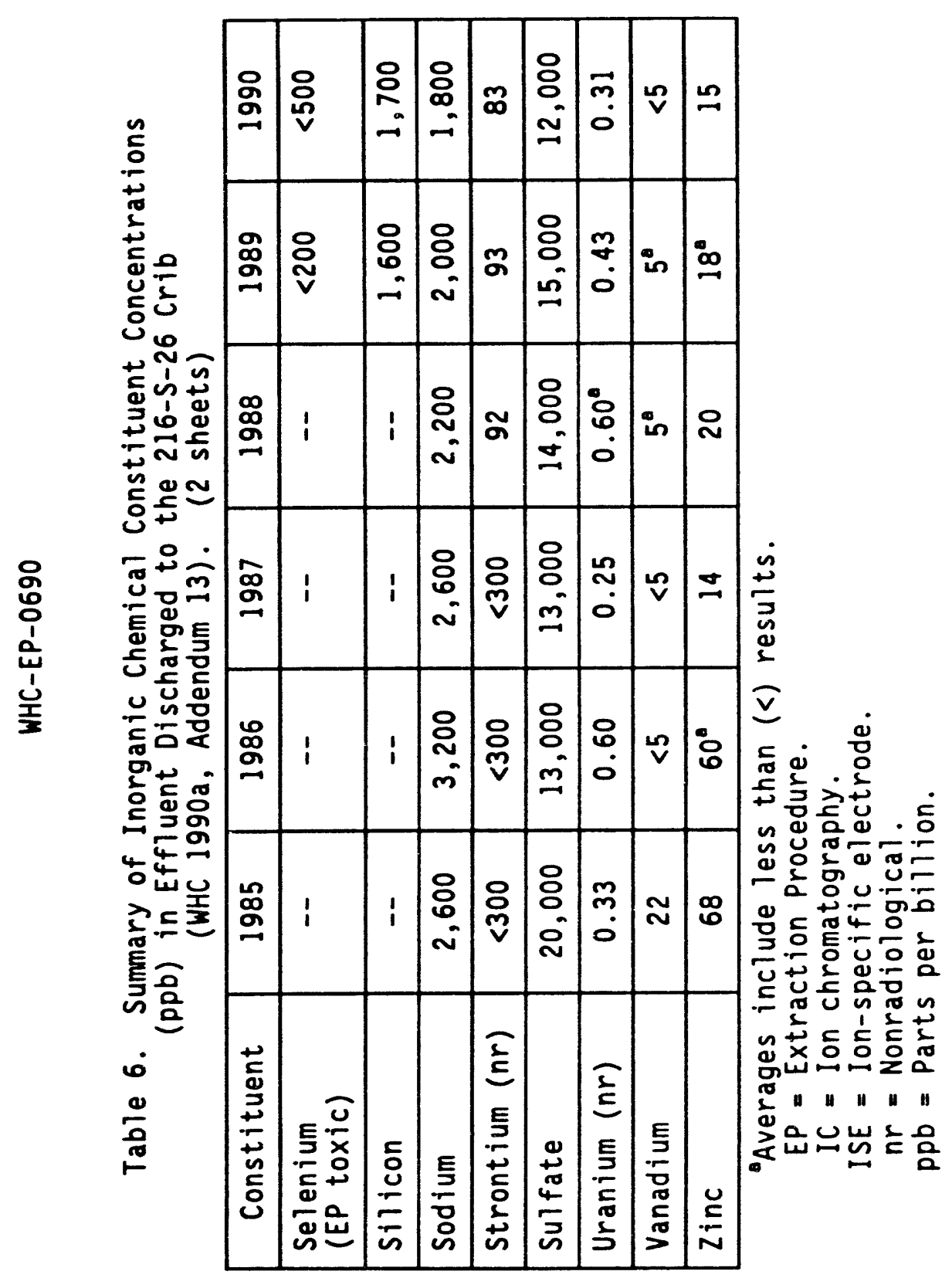




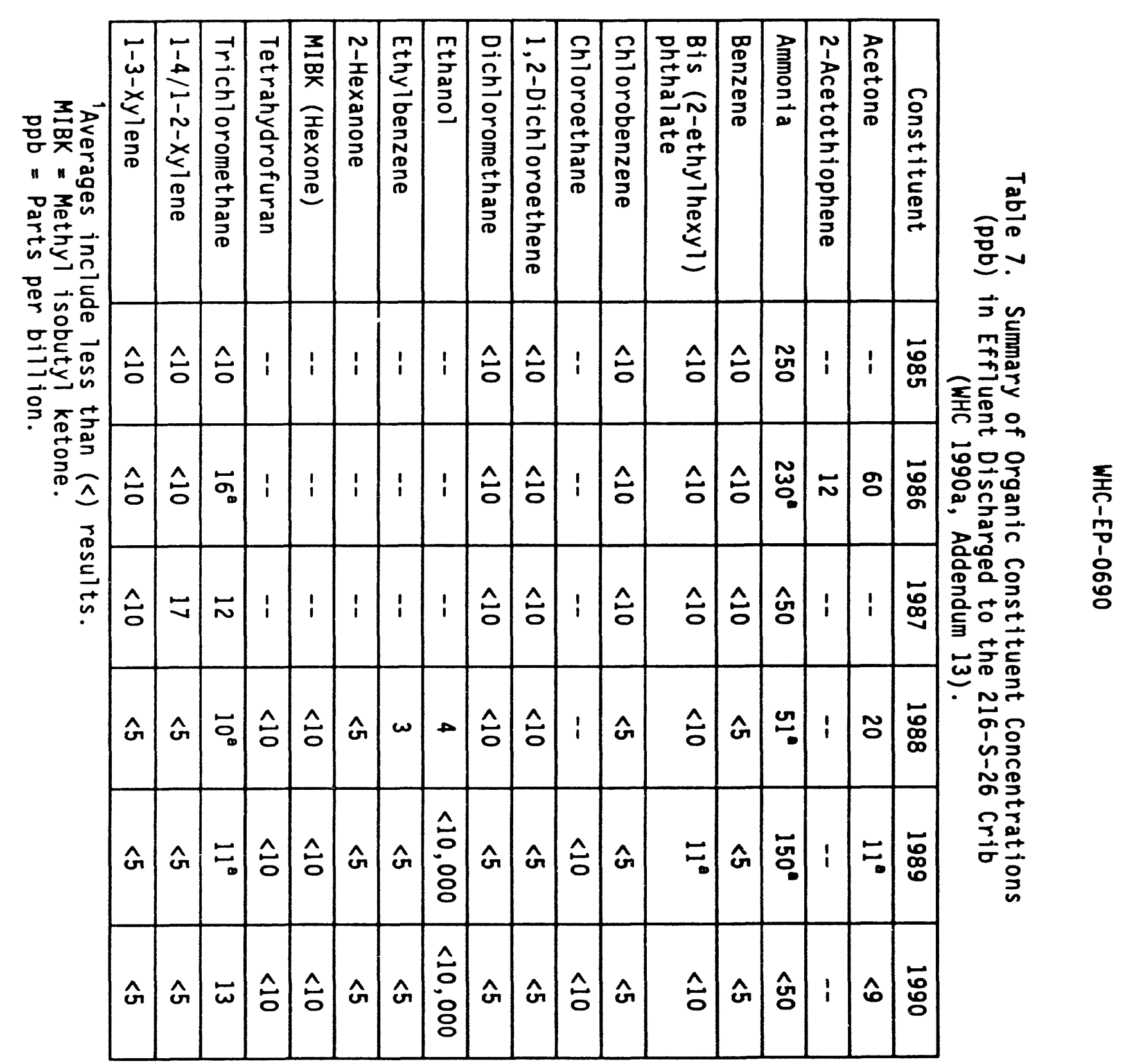


Table 8. Summary of Physical and Radiological Constituent Concentrations (ppb, except where otherwise indicated) in Effluent Discharged to the 216-S-26 Crib (WHC 1990a, Addendum 13). (2 sheets)

\begin{tabular}{|c|c|c|c|c|c|c|}
\hline Constituent & 1985 & 1986 & 1987 & 1988 & 1989 & 1990 \\
\hline $\begin{array}{l}\text { Alkal inity } \\
\text { (Method B) }\end{array}$ & -- & - & -- & -- & 48,000 & 46,000 \\
\hline $\begin{array}{l}\text { Gross alpha } \\
(\mathrm{pC} i / L)\end{array}$ & 10.0 & 3.8 & 0.79 & $1.0^{\circ}$ & $1.1^{\circ}$ & $<0.29$ \\
\hline $\begin{array}{l}\text { Gross beta } \\
(\mathrm{pCi} / \mathrm{L})\end{array}$ & 29 & 4.7 & 5.6 & $3.6^{\circ}$ & $1.7^{\circ}$ & 3.9 \\
\hline $\begin{array}{l}\text { Conductivity } \\
(\mu S)\end{array}$ & 140 & 100 & 140 & 130 & 150 & 140 \\
\hline $\begin{array}{l}\operatorname{Ignitability} \\
\left({ }^{\circ} \mathrm{F}\right)\end{array}$ & -- & -- & -- & -- & 21 & 21 \\
\hline $\mathrm{pH}$ & 7.6 & 6.3 & 6.4 & 6.3 & 6.4 & 7.3 \\
\hline $\begin{array}{l}\text { Reactivity } \\
\text { cyanide } \\
\text { (mg/kg) }\end{array}$ & -- & -- & -- & -- & $<100$ & $<100$ \\
\hline $\begin{array}{l}\text { Reactivity } \\
\text { sulfide } \\
\text { (mg/kg) }\end{array}$ & -- & -- & -- & -- & $<100$ & $<100$ \\
\hline $\begin{array}{l}\text { Suspended } \\
\text { solids }\end{array}$ & -- & -- & -- & -- & $7,000^{\circ}$ & $<5,000$ \\
\hline $\begin{array}{l}\text { Total } \\
\text { dissolved } \\
\text { solids }\end{array}$ & -- & -- & -- & -- & 72,000 & 34,000 \\
\hline $\begin{array}{l}\text { Temperature } \\
\left({ }^{\circ} \mathrm{C}\right)\end{array}$ & 21 & 28 & 17 & 20 & 23 & 17 \\
\hline $\begin{array}{l}\text { Total organic } \\
\text { carbon }\end{array}$ & $<980$ & 2,800 & $<880$ & 1,200 & 1,200 & 1,100 \\
\hline Total carbon & -- & -- & -- & -- & 12,000 & 13,000 \\
\hline $\begin{array}{l}\text { Total organic } \\
\text { halides } \\
\text { (as chloride) }\end{array}$ & $<28$ & $94^{\circ}$ & 83 & 73 & 75 & 84 \\
\hline $\begin{array}{l}\text { Americium-241 } \\
(\mathrm{DC} i / L)\end{array}$ & -- & -- & -- & -- & 1.0 & 0.074 \\
\hline
\end{tabular}


Table 8. Summary of Physical and Radiological Constituent Concentrations (ppb, except where otherwise indicated) in Effluent Discharged to the 216-S-26 Crib (WHC 1990a, Addendum 13). (2 sheets)

\begin{tabular}{|l|c|c|c|c|c|c|}
\hline \multicolumn{1}{|c|}{ Constituent } & 1985 & 1986 & 1987 & 1988 & 1989 & 1990 \\
\hline Carbon-14 (pCi/L) & -- & -- & -- & -- & $3.0^{\circ}$ & $<1.55$ \\
\hline Tritium (pCi/L) & -- & -- & -- & -- & $190^{\circ}$ & $>137$ \\
\hline $\begin{array}{l}\text { Plutonium-238 } \\
\text { ( } p C i / L)\end{array}$ & -- & -- & -- & -- & 0.021 & $<0.0018$ \\
\hline $\begin{array}{l}\text { Plutonium-239/240 } \\
\text { (pCi } / L)\end{array}$ & -- & -- & -- & -- & 0.28 & 0.038 \\
\hline $\begin{array}{l}\text { Radium-Tota1 } \\
\text { (pCi/L) }\end{array}$ & -- & -- & -- & -- & $0.14^{\circ}$ & $<0.0045$ \\
\hline $\begin{array}{l}\text { Strontium-90 } \\
\text { (pCi/L) }\end{array}$ & -- & -- & -- & -- & $0.13^{\circ}$ & $<0.099$ \\
\hline $\begin{array}{l}\text { Uranium-234 } \\
\text { (pCi/L) }\end{array}$ & -- & -- & -- & -- & 0.089 & 0.16 \\
\hline $\begin{array}{l}\text { Uranium-238 } \\
\text { (pCi/L) }\end{array}$ & -- & -- & -- & -- & 0.092 & 0.13 \\
\hline
\end{tabular}

"Averages include less than $(<)$ results. $\mathrm{pCi} / \mathrm{L}=$ Picocuries per liter. $\mathrm{ppb}=$ Parts per billion. 
Table 9. Radiological and Chemical Loading Rates for Historical Discharges to the 216-S-26 Crib (adapted from WHC 1990C).

( 2 sheets)

Flow Rate: 2.34 E+06 L/month

\begin{tabular}{|c|c|c|}
\hline Constituent & $\mathrm{kg} / \mathrm{L}^{\circ}$ & $\mathrm{kg} /$ month $^{\circ}$ \\
\hline Barium & $2.82 E-08$ & $6.60 \mathrm{E}-02$ \\
\hline Boron & $1.65 E-08$ & 3.86 E-02 \\
\hline Calcium & $1.69 \mathrm{E}-05$ & $3.95 E+01$ \\
\hline Chloride & $3.70 \mathrm{E}-06$ & $8.66 E+00$ \\
\hline Copper & $1.52 \mathrm{E}-07$ & $3.56 \mathrm{E}-01$ \\
\hline Fluoride & $1.25 \mathrm{E}-07$ & $2.92 \mathrm{E}-01$ \\
\hline Iron & 1.26 E-07 & $2.95 \mathrm{E}-01$ \\
\hline Magnesium & $3.94 E-06$ & $9.22 E+00$ \\
\hline Manganese & $7.25 E-09$ & $1.70 \mathrm{E}-02$ \\
\hline Nitrate & $5.75 \quad E-07$ & $1.35 E+00$ \\
\hline Potassium & $7.64 E-07$ & $1.79 E+00$ \\
\hline Silicon & $1.95 \mathrm{E}-06$ & $4.56 E+00$ \\
\hline Sodium & $2.13 \mathrm{E}-06$ & $4.98 E+00$ \\
\hline Strontium (nr) & $9.15 \mathrm{E}-08$ & $2.14 E-01$ \\
\hline Sulfate & $1.31 E-05$ & $3.07 E+01$ \\
\hline Uranium (nr) & $5.24 E-10$ & $1.23 \mathrm{E}-03$ \\
\hline Vanadium & $5.50 \mathrm{E}-09$ & $1.29 E-02$ \\
\hline Zinc & $1.52 \mathrm{E}-08$ & $3.56 \mathrm{E}-02$ \\
\hline Acetone & $1.02 \mathrm{E}-08$ & $2.39 \mathrm{E}-02$ \\
\hline Ammonia & $6.72 \mathrm{E}-08$ & $1.57 \mathrm{E}-01$ \\
\hline Trichloromethane (chloroform) & $1.97 \mathrm{E}-08$ & $4.61 E-02$ \\
\hline Unknown amide & $2.60 \mathrm{E}-08$ & $6.08 E-02$ \\
\hline Alpha activity" & $2.00 \mathrm{E}-12$ & $4.68 E-06$ \\
\hline Beta activity" & $2.60 E-12$ & $6.08 \mathrm{E}-06$ \\
\hline Suspended solids & $9.25 \mathrm{E}-06$ & $2.16 E+01$ \\
\hline Total dissolved solids & 5.82 E-05 & $1.36 E+02$ \\
\hline Total organic carbon & $1.05 E-06$ & $2.46 E+00$ \\
\hline
\end{tabular}







chemical loading rates for historical discharges. At the time of this report, there are no new chemical or radiological data available other than routine analytical data used to determine if wastewater is below release criteria (WAC 173-303, WHC 1988).

Environmental Assurance publishes a yearly report (Environmental Releases for Calendar Year 1984 through 1992) with total volumes and radiological loading for specific release sites. Figure 9 summarizes the yearly results for the radionuclides released to the $S-26 \mathrm{Crib}$.

\subsubsection{Constituents of Interest and Key Indicators}

The 207-SL Retention Basin effluent is routinely analyzed for constituents of interest that are the most probable contaminants generated by the 222-S Laboratory process. The 222-S Laboratory Sampling and Analysis Plan (Warwick 1992) designated the following list of key indicators for detection of the constituents of interest. The key indicators are as follows:

- Gross alpha

- Gross beta

- TOC

- Nitrate

- $\mathrm{pH}$. basis:

The following radionuclides are analyzed for and reported on a monthly

- Strontium-90

- Cesium-137

- Total uranium

- Plutonium-239/240

- Americium-241.

The 222-S Laboratory Sampling and Analysis Plan (Warwick 1992) will periodically analyze a more extensive list of constituents. Currently no new data were available for use from the extended analyte list. The revised list includes the following analytes:

- Inductively coupled plasma metals

- Organochlorine and polychlorinated bihphenyls

- Organophosphorus herbicides

- Chlorinated herbicides

- Volatile organic analysis

- Semivolatile organics

- Sulfides

- TOC

- Total oil and grease

- Chemicar oxygen demand

- Anions and cations

- Alkalinity

- Total dissolved solids

- $\mathrm{pH}$

- Specific conductance. 
Figure 9. Summary of the Yearly Results for (a) Gross Alpha and Gross Beta and (b) Radionuclides Released to the 216-S-26 Crib.
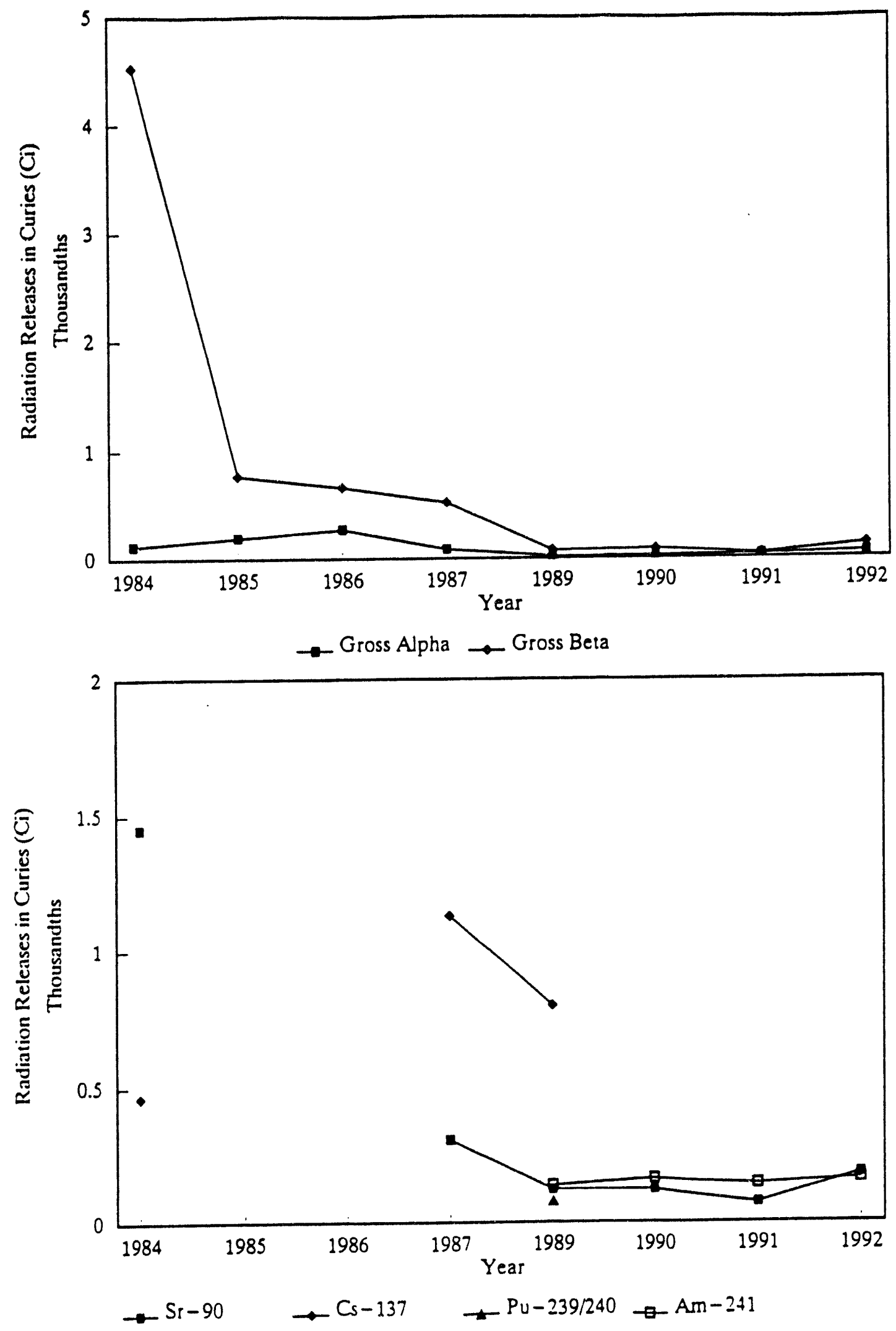


\subsection{9-S MASTE STORAGE FACILITY, 222-SA ANALYTICAL CHEMICAL STANDARDS LABORATORY, AND 291-S EXHAUST FAN CONTROL HOUSE AND STACK}

The 219-S Waste Storage Facility, 222-SA Analytical Chemical Standards Laboratory, and the 291-S Exhaust Fan Control House and Stack are discussed together in this section because the amount of wastewater and potential wastewater contamination is very low compared to the 222-S Laboratory discussed in Section 3.1.

\subsubsection{Layout and System Operation}

Originally the 219-S Waste Storage Facility discharged cooling water from Tanks 101, 102, and 103 cooling water jackets, operating gallery sump number 8 , and steam condensate from the operation gallery to the 207-SL Retention Basin. Cooling water outlets from Tanks 101, 102, and 103 cooling water jackets has been disconnected and no longer discharge to the 207-SL Retention Basin. The effluent was nonradioactive and nonhazardous when it was being discharged (Warwick 1992).

The 222-SA Analytical Chemical Standards Laboratory (222-SA) is a fiveunit wide trailer. The laboratory contains two sections: preparation of nonradioactive standards and nonradioactive process development. The wastewater stream is considered nonradioactive and nonhazardous and comes from laboratory sinks, fume hoods, safety eyewash, and glass washers. The wastewater is discharged into the S-26 Crib system downstream from the 207-SL Retention Basin. Therefore, the wastewater stream is not routinely sampled and analyzed (WHC 1990a, Addendum 13). Administrative controls are in place to help prevent discharges of hazardous waste to the stream. Operating procedures for disposal of liquid waste to laboratory sinks and drains specifically state that hazardous chemicals may not be disposed of to the effluent stream. It was demonstrated that the potential exists for a Comprehensive Environmental Response, Compensation, and Liability Act of 1980 (CERCLA) reportable spill to occur to the 222-SA wastewater stream; therefore, the stream will be redirected to the 207-SL Retention Basin (Warwick 1992).

The 291-S Waste Storage Facility discharges cooling water and steam condensate from the emergency exhaust fan to the 207-SL Retention Basin after bypassing the sampling unit. This wastewater has no credible potential for containing radioactive or hazardous wastes. During warmer periods of the year, the valve is kept closed except when the fan is running. The emergency fan only operates about 30 hours/yr. When cooler weather arrives, the valve is left partially open to allow a small continuous flow to prevent the line from freezing. There is little potential for contamination by radioactive or hazardous wastes, so the waste stream is not sampled.

\subsubsection{Discharge Volume and Flow Regime}

Discharges from the 219-S Waste Storage Facility that are routed to the 207-SL Retention Basin are small in volume compared to the volume of wastewater from the 222-S Laboratory. The volume is estimated at $3,785 \mathrm{~L} / \mathrm{yr}$ (1,000 gal/yr) (Warwick 1992). 
Discharges routed directly to the crib from the 222-SA Analytical Chemical Standards Laboratory and 291-S Exhaust Control House and Stack are $1,381,525$ and $52,990 \mathrm{~L} / \mathrm{yr}(365,000$ and $14,000 \mathrm{gal} / \mathrm{yr})$, respectively.

\subsubsection{Effluent Constituents}

Wastewater from the 219-5 Waste Storage Facility is combined with wastewater for the 222-S Laboratory in the 207-SL Retention Bas in before sampling and routing to the S-26 Crib. Effluent data that apply to the 222-S Laboratory also apply to the 219-S Waste Storage Facility (see Section 3.1.3).

Wastewater from the 222-SA Analytical Chemical Standards Laboratory and the 291-S Exhaust Fan Control House and Stack are not sampled. These facilities discharge to the system downstream of the 207-SL Retention Basin; therefore, data about effluent constituents from these sources are unavailabie. Table 10 is a list of 222-SA Laboratory chemical stock. The only chemicals routinely discharged from the 222-SA Laboratory are soaps used in cleaning used glassware. Used glassware is triple rinsed into accumulation containers that are managed and disposed of in labpacks according to WAC 173-303 requirements. The glassware is then washed in ultrasonic cleaners. This ultrasonic cleaning soiution is discharged to the S-26 Crib. Table 11 lists the commercial cleaners used (WHC 1990a, Addendum 13).

\subsubsection{Constituents of Interest and Key Indicators}

Because the wastewater for the 219-S Waste Storage Facility is combined with the wastewater from 222-S Laboratory, the constituents of interest and key indicators will be the same ones as discussed in Section 3.1.4.

In the spring of 1994 all effluents from the 222-SA Analytical Chemical Standards Laboratory and the 291-S Exhaust Fan Control House and Stack will be rerouted to the 207-SL Retention Basin. At this time, the effluents will be sampled and analyzed for the following constituents:

- Gross alpha

- Gross beta

- TOC

- Nitrate

- pH.

The samples will also be analyzed for specific radionuclides on a monthly basis. Currently the effluent (wastewater streams) from these two facilities is nonradioactive and nonhazardous. 
Table 10. 222-SA Laboratory Chemical Stock

(WHC 1990a, Addendum 13). (5 sheets)

\begin{tabular}{|l|c|c|}
\hline \multicolumn{1}{|c|}{ Chemical name } & $\begin{array}{c}\text { Number of } \\
\text { containers }\end{array}$ & Total amount \\
\hline Acetic acid, glacial & 1 & $500 \mathrm{~mL}$ \\
\hline Agar & 1 & $5,000 \mathrm{~g}$ \\
\hline Ethyl alcohol & 1 & $250 \mathrm{~mL}$ \\
\hline Methyl alcohol (anhydrous) & 1 & $300 \mathrm{~mL}$ \\
\hline Aluminum (granular) & 1 & $450 \mathrm{~g}$ \\
\hline Aluminum (shot) & 2 & $4,000 \mathrm{~g}$ \\
\hline Aluminum nitrate (nonahydrate) & 8 & $4,000 \mathrm{~g}$ \\
\hline Aluminum sulfate & 1 & $500 \mathrm{~g}$ \\
\hline Ammonium bicarbonate & 1 & $453 \mathrm{~g}$ \\
\hline Ammonium carbonate & 1 & $300 \mathrm{~g}$ \\
\hline Ammonium citrate (dibasic) & 1 & $5,000 \mathrm{~g}$ \\
\hline Ammonium fluoride & 1 & $250 \mathrm{~g}$ \\
\hline Ammonium nitrate & 3 & $1,500 \mathrm{~g}$ \\
\hline Ammonium oxalate & 1 & $300 \mathrm{~g}$ \\
\hline Ascarite II (SiO coated with $\mathrm{NaOH})$ & 1 & $500 \mathrm{~g}$ \\
\hline Ascorbic acid & 2 & $400 \mathrm{~g}$ \\
\hline Barium chloride & 1 & $300 \mathrm{~g}$ \\
\hline Barium nitrate & 2 & $1,000 \mathrm{~g}$ \\
\hline Bismuth phosphate & 3 & $1,500 \mathrm{~g}$ \\
\hline Bcric acid & 1 & $200 \mathrm{~g}$ \\
\hline Calcium carbonate & 1 & $300 \mathrm{~g}$ \\
\hline Calcium chloride & 1 & $400 \mathrm{~g}$ \\
\hline Calcium fluoride & $250 \mathrm{~g}$ \\
\hline Calcium hydroxide & $600 \mathrm{~g}$ \\
\hline Calcium nitrate & $600 \mathrm{~g}$ \\
\hline Carbon tetrachloride & $30 \mathrm{~mL}$ \\
\hline Cesium nitrate & $400 \mathrm{~g}$ \\
\hline
\end{tabular}


Table 10. 222-SA Laboratory Chemical Stock

(WHC 1990a, Addendum 13). (5 sheets)

\begin{tabular}{|l|c|c|}
\hline \multicolumn{1}{|c|}{ Chemical name } & $\begin{array}{c}\text { Number of } \\
\text { containers }\end{array}$ & Total amount \\
\hline Chromic acid & 1 & $\mathrm{NA}$ \\
\hline Chromium nitrate & 1 & $300 \mathrm{~g}$ \\
\hline Citric acid & 2 & $500 \mathrm{~g}$ \\
\hline Cobalt chloride & 1 & $200 \mathrm{~g}$ \\
\hline Cupric nitrate & 1 & $100 \mathrm{~g}$ \\
\hline Diatomaceous earth & 1 & $100 \mathrm{~g}$ \\
\hline 5-(4-Dimethylaminobenzilidene)-rhodamine & 1 & $10 \mathrm{~g}$ \\
\hline Dowex 1-X8, Dowex-1-chloride & 1 & $450 \mathrm{~g}$ \\
\hline EDTA (acid form) & 6 & $2,400 \mathrm{~g}$ \\
\hline EDTA disodium & 3 & $150 \mathrm{~g}$ \\
\hline EDTA tetrasodium & 2 & $1,500 \mathrm{~g}$ \\
\hline Ferric nitrate (iron III) & 1 & $500 \mathrm{~g}$ \\
\hline Ferric oxide (iron III) & 2 & $800 \mathrm{~g}$ \\
\hline Ferric sulfate & 1 & $100 \mathrm{~g}$ \\
\hline Ferrous sulfate (iron II) & 1 & $100 \mathrm{~g}$ \\
\hline Fluorescein & 1 & $500 \mathrm{~g}$ \\
\hline Fluorescein disodium salt, 2-hydrate & 2 & $1,000 \mathrm{~g}$ \\
\hline Glycolic acid & 2 & $350 \mathrm{~g}$ \\
\hline Hexane (HPLC grade) & 1 & $100 \mathrm{~mL}$ \\
\hline Hydrofluoric acid 48\% & 2 & $\mathrm{NA}$ \\
\hline Hydroxylamine hydrochloride & 1 & $1,700 \mathrm{~g}$ \\
\hline HEDTA trisodium salt & 1 & $1,500 \mathrm{~g}$ \\
\hline Iminodiacetic acid & $400 \mathrm{~g}$ \\
\hline Iodine & 1 & $500 \mathrm{~g}$ \\
\hline Iron (metal) & $500 \mathrm{~g}$ \\
\hline Lanthanum nitrate (hexahydrate) & $1,200 \mathrm{~g}$ \\
\hline Lead nitrate & $4,000 \mathrm{~g}$ \\
\hline Lithium metaborate & $500 \mathrm{~g}$ \\
\hline
\end{tabular}


Table 10. 222-SA Laboratory Chemical Stock

(WHC 1990a, Addendum 13). (5 sheets)

\begin{tabular}{|c|c|c|}
\hline Chemical name & $\begin{array}{l}\text { Number of } \\
\text { containers }\end{array}$ & Total amount \\
\hline Magnesium hydroxide & 3 & $700 \mathrm{~g}$ \\
\hline Magnesium nitrate (hexahydrate) & 1 & $300 \mathrm{~g}$ \\
\hline Magnesium sulfate (anhydrous) & 1 & $500 \mathrm{~g}$ \\
\hline Manganese II nitrate $50 \%$ & 1 & $300 \mathrm{~g}$ \\
\hline Marble $\left(\mathrm{CaCO}_{3}\right.$ chips $)$ & 1 & $500 \mathrm{~g}$ \\
\hline Mercury & 2 & $235 \mathrm{~mL}$ \\
\hline Mercury indicator & 1 & $100 \mathrm{~g}$ \\
\hline Mercurous nitrate & 1 & $200 \mathrm{~g}$ \\
\hline Methyl isobutyl ketone (hexone) & 1 & $250 \mathrm{~mL}$ \\
\hline Methyl red & 1 & $25 \mathrm{~g}$ \\
\hline Molybdenum trioxide (VI oxide) & 1 & $170 \mathrm{~g}$ \\
\hline Nickel nitrate & 1 & $100 \mathrm{~g}$ \\
\hline Nitrilotriacetic acid (trisodium) & 1 & $500 \mathrm{~g}$ \\
\hline Nitroethane & 2 & $6,000 \mathrm{~g}$ \\
\hline Normal paraffin hydrocarbon & 1 & $500 \mathrm{~mL}$ \\
\hline Oxalic acid & 1 & $10 \mathrm{~g}$ \\
\hline Potassium chromate & 1 & $12 \mathrm{~g}$ \\
\hline Potassium fluoride & 4 & $1,600 \mathrm{~g}$ \\
\hline Potassium hydroxide & 2 & $600 \mathrm{~g}$ \\
\hline Potassium iodide & 1 & $100 \mathrm{~g}$ \\
\hline Potassium nitrate & 3 & $1,200 \mathrm{~g}$ \\
\hline Potassium nitrite & 1 & $300 \mathrm{~g}$ \\
\hline Potassium permanganate & 2 & $700 \mathrm{~g}$ \\
\hline Potassium acid phthalate & 1 & $100 \mathrm{~g}$ \\
\hline Rare earth nitrate $(\mathrm{La}, \mathrm{Nd})\left(\mathrm{NO}_{3}\right)_{3}$ & 1 & $250 \mathrm{~g}$ \\
\hline Silica gel & 1 & $500 \mathrm{~g}$ \\
\hline Silicic acid, N-hydrate & 1 & $400 \mathrm{~g}$ \\
\hline Soda and lime $\left(\mathrm{Na}_{2} \mathrm{CO}_{3}\right.$ and $\left.\mathrm{CaO}\right)$ & 1 & $2,500 \mathrm{~g}$ \\
\hline
\end{tabular}


Table 10. 222-SA Laboratory Chemical Stock (WHC 1990a, Addendum 13). (5 sheets)

\begin{tabular}{|l|c|c|}
\hline \multicolumn{1}{|c|}{ Chemical name } & $\begin{array}{c}\text { Number of } \\
\text { containers }\end{array}$ & Total amount \\
\hline Sodium acetate (trihydrate) & 3 & $5,500 \mathrm{~g}$ \\
\hline Sodium aluminate & 1 & $1,500 \mathrm{~g}$ \\
\hline Sodium borate (tetraborate, decahydrate) & 1 & $500 \mathrm{~g}$ \\
\hline Sodium carbonate & 2 & $600 \mathrm{~g}$ \\
\hline Sodium chloride & 1 & $2,500 \mathrm{~g}$ \\
\hline Sodium chloride & 1 & $200 \mathrm{~g}$ \\
\hline Sodium citrate & 3 & $1,500 \mathrm{~g}$ \\
\hline Sodium chromate & 1 & $400 \mathrm{~g}$ \\
\hline Sodium fluoride & 1 & $250 \mathrm{~g}$ \\
\hline Sodium hydroxide & 2 & $800 \mathrm{~g}$ \\
\hline Sodium iodide & 1 & $250 \mathrm{~g}$ \\
\hline Sodium Meta-bisulfate & 2 & $1,000 \mathrm{~g}$ \\
\hline Sodium nitrate & 1 & $2,500 \mathrm{~g}$ \\
\hline Sodium nitrite & 2 & $193 \mathrm{~kg}$ \\
\hline Sodium phosphate (dibasic, anhydrous) & 3 & $1,500 \mathrm{~g}$ \\
\hline Sodium phosphate (monobasic) & 1 & $300 \mathrm{~g}$ \\
\hline Sodium phosphate (tribasic, dodecahydrate) & 2 & $500 \mathrm{~g}$ \\
\hline Sodium sulfate & 2 & $2,600 \mathrm{~g}$ \\
\hline Sodium sulfite & 1 & $500 \mathrm{~g}$ \\
\hline Sodium sulfide, 9-hydrate & 1 & $500 \mathrm{~g}$ \\
\hline Sodium tartrate & 2 & $1,000 \mathrm{~g}$ \\
\hline Sodium thiosulfate & 1 & $500 \mathrm{~g}$ \\
\hline Starch (amylum) & 2 & $500 \mathrm{~g}$ \\
\hline Strontium fluoride & 1 & $500 \mathrm{~g}$ \\
\hline Sucrose & $2,000 \mathrm{~g}$ \\
\hline Sulfuric acid, ultrex grade & $\mathrm{l}$ & $\mathrm{NA}$ \\
\hline
\end{tabular}


Table 10. 222-SA Laboratory Chemical Stock (WHC 1990a, Addendum 13). (5 sheets)

\begin{tabular}{|l|c|c|}
\hline \multicolumn{1}{|c|}{ Chemical name } & $\begin{array}{c}\text { Number of } \\
\text { containers }\end{array}$ & Total amount \\
\hline Tributylphosphate & 1 & $500 \mathrm{~mL}$ \\
\hline $1,1,2$-Trichlorotrifluoroethane & 2 & $2 \mathrm{~L}$ \\
\hline Triethanolamine & 1 & $500 \mathrm{~g}$ \\
\hline Tris (hydroxymethyl)aminoethane & 1 & $300 \mathrm{~g}$ \\
\hline Urea & 1 & $500 \mathrm{~g}$ \\
\hline Vanadyl sulfate trihydrate & 2 & $50 \mathrm{~g}$ \\
\hline p-Xylene & 1 & $1 \mathrm{~L}$ \\
\hline Zinc acetate & $\mathrm{NA}$ & $\mathrm{NA}$ \\
\hline Zinc metal & 1 & $500 \mathrm{~g}$ \\
\hline Zinc chloride & 1 & $50 \mathrm{~mL}$ \\
\hline Zirconium nitrate & 1 & $200 \mathrm{~g}$ \\
\hline
\end{tabular}

EDTA = Ethylenediametetraacetic acid.

HEDTA $=\mathrm{N}$-(hydroxyethyl)-ethylenediaminetriacetic acid.

HPLC = High pressure liquid chromatography.

$N A=$ Not applicable (at this time). 
Table 11. Commercial Cleaners Used in the 222-SA Analytical Chemical Standards Laboratory (WHC 1990a, Addendum 13).

\begin{tabular}{|c|}
\hline ultrasonic cleaning solution (Generic) \\
\hline Markson All-Purpose Detergent \\
\hline Markson Ammoniated Detergent \\
\hline Markson Sonic Phosphoric Detergent \\
\hline ESPI DeContam \\
\hline
\end{tabular}

ESPI = Electronic Space Products, Inc., Los Angeles, California.

-Markson is a trademark of Markson Science Incorporated.

Decontam is a trademark of Electronic Space Products, Inc., Los Angeles, California. It is an alkaline cleaning solution of $\mathrm{pH}=12$ at full strength. 
WHC-EP-0690

\subsection{CONCEPTUAL MODEL OF HYDROLOGIC RESPONSE AND CONTAMINANT MIGRATION}

\subsection{HYDROGEOLOGIC FRAMEWORK}

\subsubsection{Regional and Hanford Site Geology}

The Pasco Basin and the Hanford Site are underlain by pre-Miocene sedimentary and crystalline rocks (Campbell 1989), Miocene-aged (17.5 to $6 \mathrm{Ma}$ ) basalts of the Columbia River Basait Group (CRBG) (Myers et al. 1979; Reidel and Fecht 1981; DOE 1988; Tolan et al. 1989; Reidel et al. 1989, 1992), interbedded sediments of the Ellensburg Formation (Reidel and Fecht 1981; DOE 1988; Smith 1988), and a late-Miocene- to Holocene-aged (<8.5 Ma to present) suprabasalt sediment sequence (Myers et al. 1979; Tallman et al. 1981; DOE 1988; Smith et a1. 1989; Lindsey 1991a, 1991b; Reidel et a1. 1992).

4.1.1.1 Columbia River Basalt Group. The CRBG is an assemblage of tholeijtic, continental flood basalts that cover an area of more than $163,157 \mathrm{~km}^{2}\left(63,000 \mathrm{mi}^{2}\right)$ in Washington, Oregon, and Idaho and have an estimated volume of about $174,356 \mathrm{~km}^{3}\left(40,800 \mathrm{mi}^{3}\right)$ (DOE 1988; Reidel and Hooper 1989; Tolan et al. 1989). The CRBG is divided into five formations, from oldest to youngest: Imnaha Basalt, Picture Gorge Basalt, Grande Ronde Basalt, Wanapum Basalt, and Saddle Mountains Basalt (DOE 1988; Tolan et al. 1989) (Figure 10). The Saddle Mountains Basalt (the uppermost basalt at the Hanford Site) is divided into (from oldest to youngest) the Umatilla, Wilbur Creek, Asotin, Esquatzel, Pomona, Elephant Mountain, and Ice Harbor Members (Reidel and Fecht 1981).

4.1.1.2 Ellensburg Formation. The Ellensburg Formation consists of volcaniclastic and siliciclastic deposits that occur between CRBG basalt flows (DOE 1988; Smith 1988). The three uppermost units of the Ellensburg Formation at the Hanford Site are, from oldest to youngest: the Selah interbed, the Rattlesnake Ridge interbed, and the Levy interbed. A detailed discussion of the Ellensburg Formation at the Hanford Site is given in Reidel and Fecht (1981). Smith (1988) and Smith et al. (1989) discuss the Ellensburg Formation and correlative units throughout the region.

4.1.1.3 Suprabasalt Sediments. Discussions of various aspects of suprabasalt sediment geology are found in Myers et al. (1979), Tallman et al. (1979, 1981), PSPL (1982), Bjornstad (1984), Fecht et a1. (1987), DOE (1988), Baker et a1. (1991), Smith et al. (1989), Delaney et al. (1991), Lindsey (199la, 1992), Lindsey et al. (1991), and Reidel et al. (1992). Delaney et al. (1991), Lindsey (1991a), and Reidel et al. (1992) provide the most recent synopsis of suprabasalt sediment geology for the Hanford Site. The following discussion is summarized from these recent reports.

The suprabasalt sedimentary sequence (Figure 11) is up to $229 \mathrm{~m}(750 \mathrm{ft}$ ) thick at the Hanford Site. It is dominated by the laterally extensive lateMiocene to Pliocene Ringold Formation and the Pleistocene Hanford formation. Laterally discontinuous units, referred to as the Plio-Pleistocene unit, early 
Figure 10. Generalized Stratigraphy of the Pasco Basin and Surrounding Area.

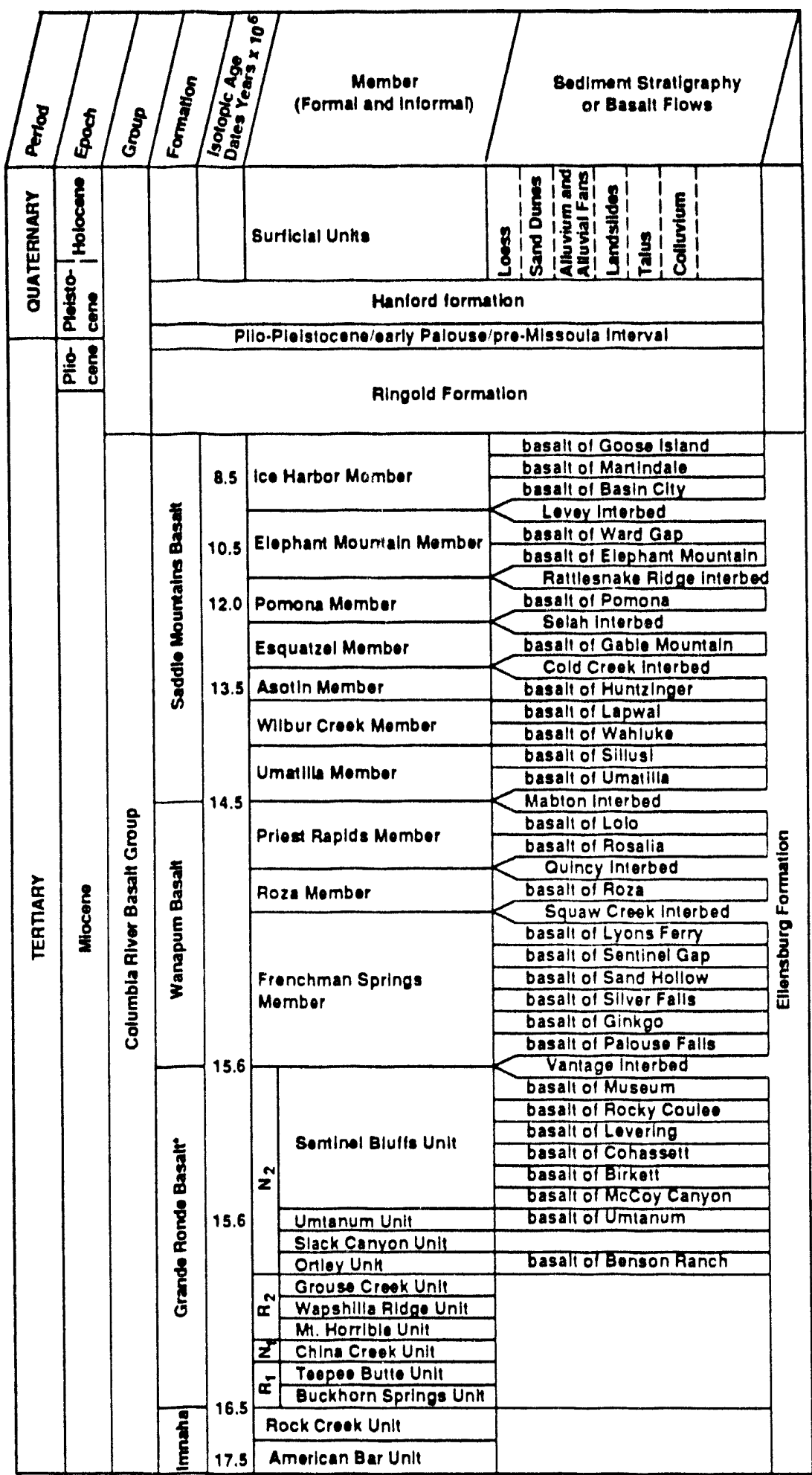

-The Grande Ronde Basalt consigts of at least $120 \mathrm{mal}$ or basalt flows. Only a few flows have been named. $N_{2}, R_{2}, N_{1}$ and $R_{1}$ are magnotostratigraphlc units. 
Figure 11. Generalized Stratigraphy of the Suprabasalt Sediments in the Pasco Basin.

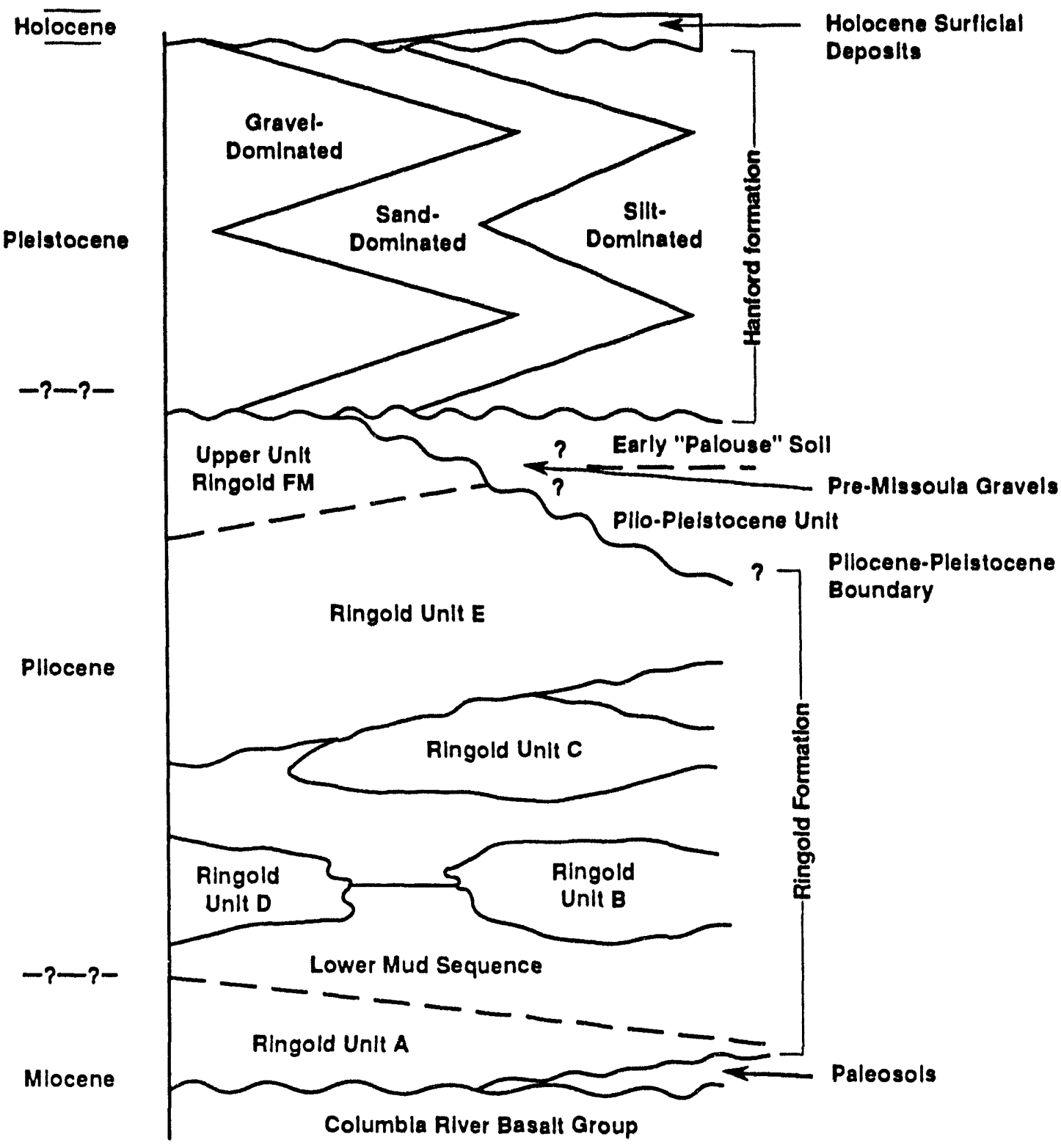

H9112007.1 
WHC-EP-0690

"Palouse" soll, and pre-Missoula gravels, separate the Hanford formation and Ringold Formation locally. Holocene-aged alluvial and eolian deposits cap the suprabasalt sequence.

The Ringold Formation is up to $183 \mathrm{~m}(600 \mathrm{ft})$ thick within the Pasco Basin; it pinches out against basalt ridges around the edge of and within the basin and consists of semi-indurated clay, silt, fine- to coarse-grained sand, and pebble to cobble gravel. Ringold deposits are grouped into five sediment facies associations (fluvial gravel, fluvial sand, overbank-paleosol, lacustrine, basaltic alluvium) that are defined on the basis of lithology, petrology, stratification, and pedogenic alteration. The associations are summarized below.

1. Fluvial gravel--Consists of clast and lesser matrix-supported pebble to cobble gravel with a fine- to medium-grained sand matrix. Grain size distributions tend to be bimodal with granules and coarsegrained sand being rare. Crude to well-defined stratification and low-angle, lenticular bedding geometries generally dominate.

2. Fluvial sand--Fine- to coarse-grained quartzo-feldspathic sands displaying well-defined stratification dominate. Fining upward packages less than one to several meters thick are common.

3. Overbank-Paleosol--Laminated to massive silty sand, silt, and clay displaying evidence of pedogenic alteration dominates.

4. Lacustrine--Characterized by well-stratified clay with interbedded silt and silty sand.

5. Basaltic alluvium--Massive to crudely stratified, weathered to unweathered, basaltic, pebble to cobble gravel, commonly with a mudrich matrix dominates.

The distribution of facies associations within the Ringold Formation forms the basis for a stratigraphic subdivision (Lindsey 199la, 1991b). The lower half of the Ringold Formation is characterized by fluvial gravel and sand-dominated intervals designated units $A, B, C, D$, and $E$ (Figures 11 and 12) that interfinger with fine-grained deposits typical of the overbankpaleosol and lacustrine facies associations. The lowest of these fine-grained intervals is designated the lower mud unit (see Figures 11 and 12). Interstratified deposits of the fluvial sand and overbank-paleosol facies associations and strata dominated by the lacustrine facies association form the upper half of the Ringold Formation (commonly referred to as the upper Ringold).

Several localized, informal units separate the Ringold Formation from the Hanford formation. These units are the (1) Plio-Pleistocene unit, (2) preMissoula gravels, and (3) early "Palouse" soil (see Figures 10 through 12) (Myers et al. 1979; Tallman et al. 1979, 1981; DOE 1988; Reidel et al. 1992). The Plio-Pleistocene unit and early "Palouse" soil consist of loess, pedogenic calcium carbonate $\left(\mathrm{CaCO}_{3}\right)$, and basaltic sands and gravels. Uncemented mixedlithology gravel with a quartzo-feldspathic matrix dominates the pre-Missoula gravels. 
Figure 12. Generalized Stratigraphic Column for the Southern 200 West Area.

$M S G$

111

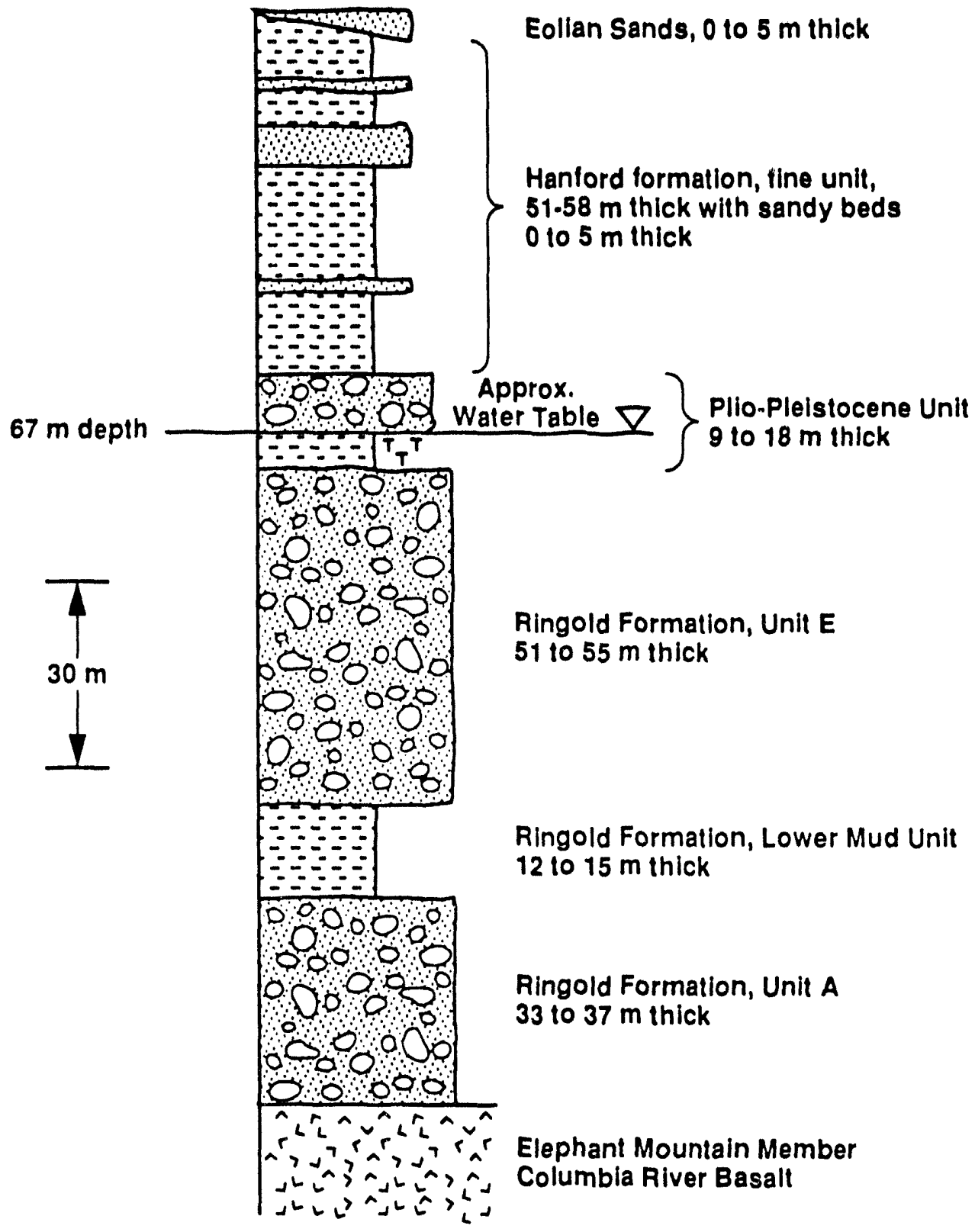

H9310020.1 
The Hanford formation consists of uncemented gravel, sand, and silt deposited by Pleistocene cataclysmic flood waters (Fecht et al. 1987; DOE 1988; Baker et al. 1991). The Hanford formation is thickest in the vicinity of the 200 West and 200 East Areas where it can be up to $107 \mathrm{~m}$ $(350 \mathrm{ft})$ thick. The Hanford formation is divided into three facies (gravel, sand, and silt dominated) that are gradational and interfinger with each other. The facies are summarized below:

1. Gravel-dominated facies--Generally consist of cross-stratified, coarse-grained sand and granule to boulder gravel that contain minor intercalated silt-rich horizons. Generally these gravels are uncemented and matrix poor, displaying an open-framework texture.

2. Sand-dominated facies--Well-stratified, fine- to coarse-grained sand and granule gravel dominate. Silt content is variable, but where it is low an open-framework texture is common. Small pebbles and ripup clasts in addition to lenticular, pebble-gravel interbeds and silty interbeds may be present.

3. Silt-dominated facies--Interbedded silt and fine- to coarse-grained sand forming well-stratified normally graded rhythmites are characteristic.

In addition to the three facies, clastic dikes also are commonly found in the Hanford formation as well as locally in other sedimentary units in the Pasco Basin (Black 1979). These clastic dikes are structures that generally cross cut bedding, although they do locally parallel bedding. The dikes consist of thin, alternating vertical to subvertical layers of silt, sand, and granules. A feature known as patterned ground can be observed where the dikes intersect the ground surface.

Holocene surficial deposits consist of silt, sand, and gravel that form a thin $(4.9-\mathrm{m}[<16-\mathrm{ft}])$ veneer across much of the Hanford Site. These sediments were deposited by a mix of eolian and alluvial processes.

4.1.1.4 Structural Geology. The Columbia Plateau is divided into three informal structural subprovinces: Blue Mountains, Palouse, and Yakima Fold Belt (Reidel et al. 1989; Tolan and Reidel 1989). These structural subprovinces are delineated based on their structural fabric. The Hanford Site is located in the eastern Yakima Fold Belt near its junction with the Palouse subprovince.

The Yakima Fold Belt consists of a series of segmented, narrow, asymmetric, and generally east-west trending anticlines that separate broad, low-amplitude structural basins (Reidel 1984; Reidel et al. 1989). The Pasco Basin (where the Hanford Site is situated) is one of the largest structural basins within the Yakima Fold Belt. The Pasco Basin is bounded on the north by the Saddle Mountains anticline, on the west by the Hog Ranch-Naneum Ridge anticline, and on the south by the Rattlesnake Mountain anticline. The Palouse slope, a west-dipping monocline, bounds the Pasco Basin on the east. The Pasco Basin is divided into the Wahluke and Cold Creek synclines by the Gable Mountain anticline, the easternmost extension of the Umtanum Ridge anticline. 


\subsubsection{Local Geology}

The closest well to the S-26 Crib is 299-W27-1, which is located adjacent to the crib on the south side (see Figure 2). Unfortunately, geologic detail is missing on the well log, which results in lack of specific geologic data in the crib's immediate vicinity. However, the site's general geology can be derived by examining other wells in the area and from studies of outcrops analogous to strata thought to occur in the vicinity of the crib. A northwest-southeast trending geologic cross section (Figure 13) through the area of the crib illustrates the strata present at the site and the relationships between the strata. Figure 3 shows the location of the geologic cross section.

Geologic trends in the vicinity of the S-26 Crib are similar to those in the 200 West Area. The Hanford formation, Plio-Pleistocene and early "Palouse" intervais, and the Ringold Formation comprise the unsaturated zone. Holocene-aged eolian sand less than a foot thick to several feet thick is found in the general vicinity of the crib site, but in many places has been removed by construction activities or other human activity.

Gravel, sand, and silt of the Hanford formation form the majority of the vadose zone in the southern 200 West Area and are divided into two main intervals, an upper coarse unit and a lower fine unit. Strata typical of the gravel-dominated facies form most of the upper coarse unit (Lindsey et al. 1991). The upper coarse unit is thickest to the north (about $24 \mathrm{~m}[80 \mathrm{ft}]$ at wells 299-W22-38 and -27) arid pinches out near well 299-W22-25 (see Figures 12 and 13). It is missing in the immediate vicinity of the $\mathrm{S}-26 \mathrm{Crib}$. Borehole data and outcrop studies elsewhere in Hanford gravels suggest minor occurrences of the sand-and silt-domirated facies may occur as lenticular interbeds within the upper coarse unit.

The lower fine unit of the Hanford formation consists of interbedded strata typical of both the sand-and silt-dominated facies. From north to south, along geologic cross section shown in Figure 13, the lower fine unit increases in thickness from approximately 18 to $61 \mathrm{~m}(60$ to $200 \mathrm{ft})$. Because the upper coarse unit pinches out north of the S-26 Crib, the lower fine unit remains as the only unit in the Hanford formation in the immediate vicinity of the crib. Gravelly interbeds may be present based on experience elsewhere in the 200 West Area. The nature of the contact between the upper and lower units is not clear. It could be either sharp or gradational.

The Hanford formation is underlain in the central 200 West Area by the early "Palouse" and Plio-Pleistocene interval. Silts that typify the early "Palouse" soil (DOE 1988, Last et al. 1989) pinch out to the south and are missing in the area of the crib. The Plio-Pleistocene interval is mostly basaltic sands and gravels containing variable amounts of pedogenic $\mathrm{CaCO}_{3}$. The combined early "Palouse" and Plio-Pleistocene interval is approximately 3 to $8 \mathrm{~m}$ (10 to $25 \mathrm{ft}$ ) thick in the northern portion of the cross section (see Figure 13) and increases to approximately $12 \mathrm{~m}(40 \mathrm{ft})$ thick in the vicinity of the S-26 crib. It generally dips to the south toward the axis of the Cold Creek syncline. Although the thickness of the Plio-Pleistocene interval increases southward, the amount of cementation by pedogenic $\mathrm{CaCO}_{3}$ decreases in 
Figure 13. North-Northwest to South-Southeast Geologic Cross Section Through the Southern Portion of the 200 West Area.

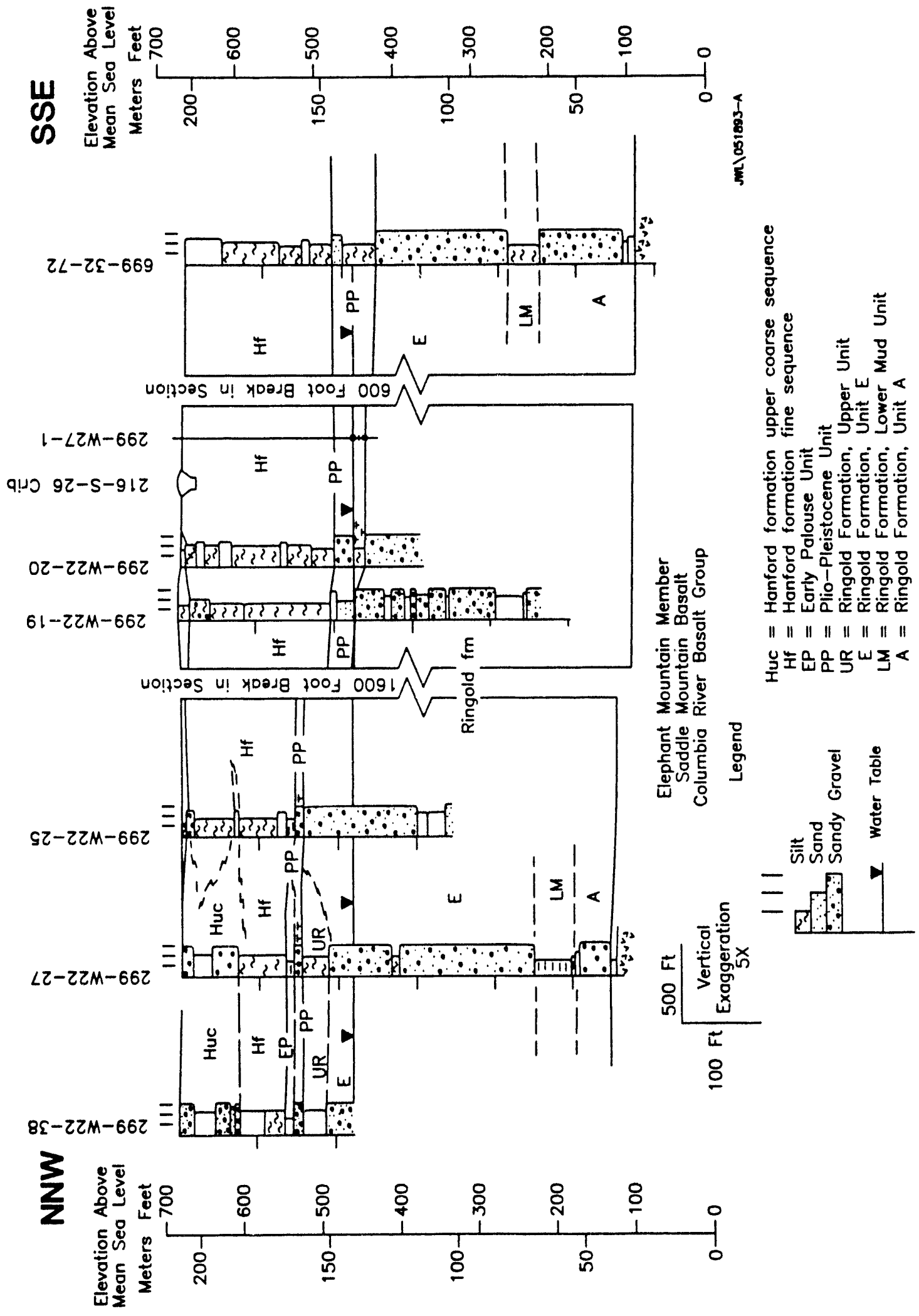


the same direction. In the southern portion of the cross section (see Figure 13) and in the vicinity of the S-26 Crib, pedogenic $\mathrm{CaCO}_{3}$ cement is weak and intermittent.

Below the Plio-Pleistocene interval in the area of the S-26 Crib is the Ringold Formation. It is the thickest unit in the southern portion of the 200 West Area and consists of the upper unit, unit $E$, the lower mud unit, and unit $A$ (see Figure 13). The upper Ringold unit is about $9 \mathrm{~m}(30 \mathrm{ft})$ thick near wel1 299-W22-38 and pinches out southward before reaching the area of the crib. It consists of strata typical of the fluvial sand and overbank-paleosol facies. The other units of the Ringold Formation are fairly uniform in thickness but dip to the south toward the axis of the Cold Creek syncline like the overlying Plio-Pleistocene interval. Ringold unit $E$ is approximately 67 to $82 \mathrm{~m}(220$ to $270 \mathrm{ft})$ thick and consists of fluvial gravel facies; however, minor interbedded occurrences of the fluvial sand and overbank-paleosol facies also may be present. The lower mud unit typically consists of the overbankpaleosol and lacustrine facies and is between 12 and $17 \mathrm{~m}$ ( 40 and $55 \mathrm{ft}$ ) thick in the area of the crib. Unit $A$ displays lithologies like those found in unit $E$ and is between 15 and $40 \mathrm{~m}$ (50 and $130 \mathrm{ft}$ ) thick.

The uppermost basalt beneath the $S-26$ Crib area is the Elephant Mountain Member of the Saddle Mountains Basalt (Reidel and Fecht 1981). The top of the basalt is approximately $177 \mathrm{~m}(580 \mathrm{ft})$ below ground surface and dips to the south toward the axis of the Cold Creek syncline at approximately $8 \mathrm{~m} / \mathrm{km}$ $(40 \mathrm{ft} / \mathrm{mi})$. Because no boreholes penetrate the Elephant Mountain Member near the crib site, precise thicknesses of the Elephant Mountain Member and underlying Rattlesnake Ridge interbed of the Ellensburg Formation are unknown. From nearby boreholes and extrapolating to the crib site, the thicknesses of the Elephant Mountain Member and Rattlesnake Ridge interbed are approximately $25 \mathrm{~m}(82 \mathrm{ft}$ ) each (Reidel and Fecht 1981).

\subsubsection{Regional and Hanford Site Hydrology}

Delaney et al. (1991) presents a synopsis of regional and Hanford Site hydrology. Conneliy et al. (1992) summarizes the hydrology of the 200 West Area. This section is summarized from Delaney et al. (1991).

4.1.3.1 Surface Water. Primary surface-water features near the Hanford Site are the Columbia and Yakima Rivers and their major tributaries: the Snake and Walla Walla Rivers. The free-flowing stretch of the Columbia River adjacent to the Hanford Site is known as the Hanford Reach. It extends from Priest Rapids Dam to the headwaters of Lake Wallula (the reservoir behind McNary Dam). Flow along the Hanford Reach is controlled by Priest Rapids Dam. Approximately one-third of the Hanford Site is drained by the Yakima River system. Cold Creek and its tributary, Dry Creek, are ephemeral streams within the Yakima River drainage system. Both streams drain areas along the western part and cross the southwestern part of the Hanford Site while flowing toward the Yakima River. West Lake, about $40,470 \mathrm{~m}^{2}$ (10 acres) in size and less than $1 \mathrm{~m}(3 \mathrm{ft})$ deep, is the only natural lake within the Hanford Site (DOE 1988a). Wastewater ponds, cribs, and ditches associated with nuclear fuel reprocessing and waste disposal activities are also present on the Hanford Site (Figure 14). 
Figure 14. Location of Water Disposal Sites on the Hanford Site.

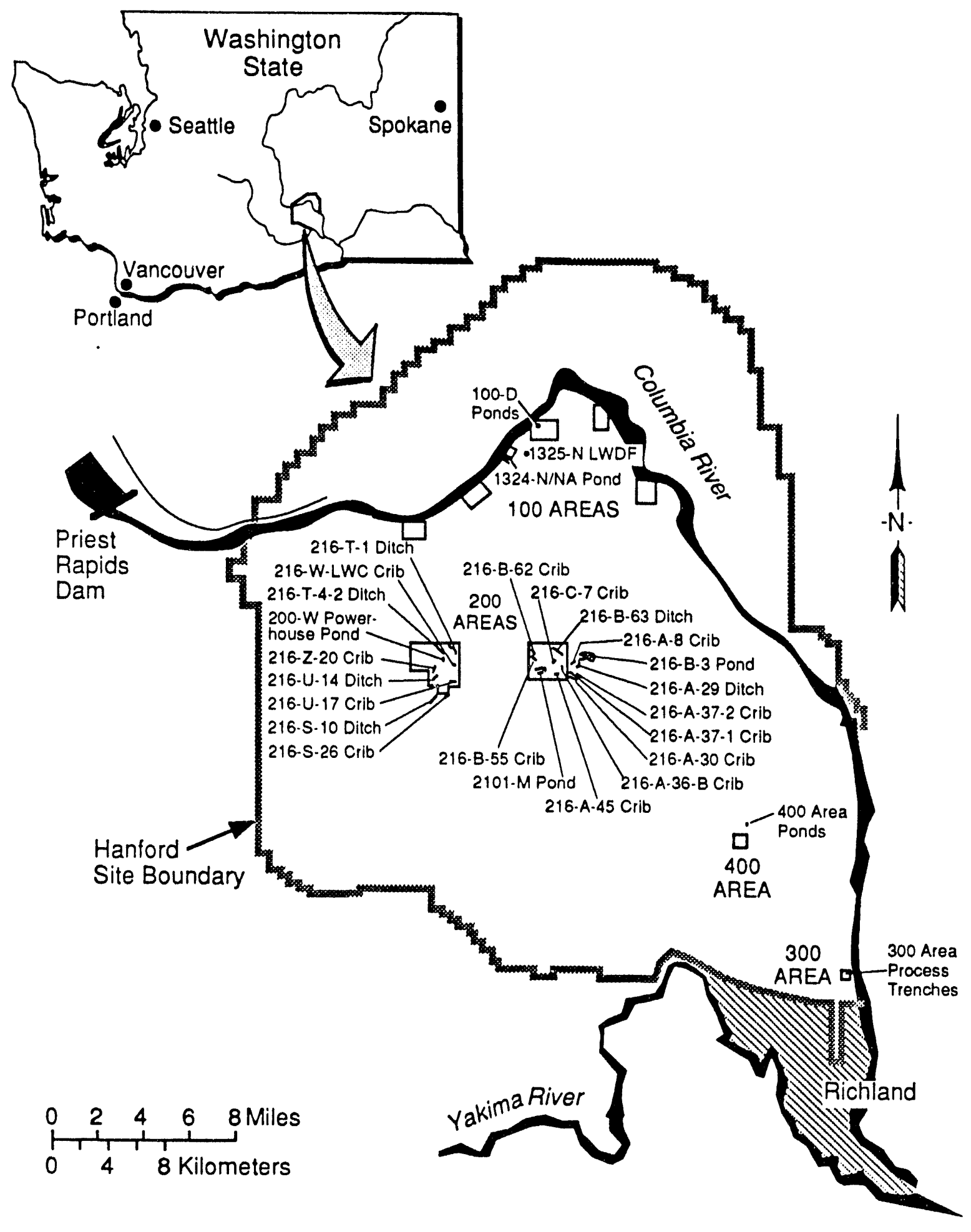

S9007025.C 
4.1.3.2 Groundwater. The Pasco Basin is characterized by a multiaquifer system. It consists of four hydrogeologic units that correspond with the upper three formations of the CRBG and the suprabasalt sediments.

Generally the basalt aquifers are confined and found within sedimentary interbeds of the Ellensburg Formation and interflow zones that occur between basalt flows. Recharge to the shallow basalt aquifers results from infiltration of precipitation and runoff along the margins of the Pasco Basin. Recharge of the deep basalt aquifers is inferred to result from interbasin groundwater movement originating northeast and northwest of the Pasco Basin in areas where the Wanapum and Grande Ronde Basalts crop out extensively (DOE 1988). Groundwater discharge from shallow basalt aquifers is probably to the overlying aquifers and the Columbia River. Discharge areas for the deeper groundwater systems are uncertain, but flow is inferred to be generally southeastward with discharge speculated to be south of the Hanford Site (DOE 1988). Erosional "windows" through dense basalt flow interiors allow direct connection between the unconfined and uppermost confined aquifers (Graham et al. 1984).

The suprabasalt sediment aquifer is in glaciofluvial deposits of the Hanford formation and alluvial/lacustrine sediments of the Ringold Formation. This aquifer lies at depths ranging from less than $3 \mathrm{~m}(1 \mathrm{ft})$ near West Lake and the Columbia and Yakima Rivers, to greater than $107 \mathrm{~m}(350 \mathrm{ft})$ near the center of the Hanford Site. The position of the water table beneath the western portion of the Hanford Site is generally within Ringold unit $E$. In the northern and eastern portions of the Hanford Site, the water table is generally within the Hanford formation. Hydraulic conductivities for the Hanford formation (610 to $3,050 \mathrm{~m} /$ day $[2,000$ to $10,000 \mathrm{ft} / \mathrm{day}])$ are much greater than those of the gravel facies of the Ringold Formation (186 to $930 \mathrm{~m} /$ day [610 to $3,050 \mathrm{ft} / \mathrm{day}])$. The main body of the unconfined aquifer occurs within the Ringold Formation.

The base of the uppermost aquifer system is defined as the surface of the uppermost basalt flow. However, overbank and lacustrine deposits in the Ringold Formation locally form confining layers for the underlying Ringold fluvial gravel and sand (unit $A$ ). The uppermost aquifer system is bounded laterally by anticlinal basalt ridges and is approximately $152 \mathrm{~m}$ (500 ft) thick near the center of the basin.

Natural recharge to the uppermost aquifer consists of rainfall and runoff from the higher bordering elevations, water infiltrating from small ephemeral streams, and river water along influent reaches of the Yakima and Columbia Rivers. The movement of moisture from precipitation through the unsaturated (vadose) zone varies. Gee (1987) and Routson and Johnson (1990) indicate it is nonexistent across much of the Hanford Site while Rockhold et al. (1990) suggest that downward water movement below the root zone is common in the 300 Area. Artificial recharge occurs from the disposal of wastewater on the Hanford Site (principally in the 200 Areas) and from large irrigation projects surrounding the Hanford Site. 


\subsubsection{6-S-26 Crib Area Hydrology}

The hydrostratigraphic units of concern in the vicinity of the S-26 Crib are the (1) the Rattlesnake Ridge interbed, (2) Elephant Mountain Basalt, (3) Ringold Formation, (4) Plio-Pleistocene and early "Palouse" interval, and (5) Hanford formation. The Rattlesnake Ridge interbed forms the uppermost confined aquifer in the area; is approximately $25 \mathrm{~m}(82 \mathrm{ft})$ thick; and consists of the flow bottom of the Elephant Mountain Basalt, the flow top of the Pomona Basalt, and the Rattlesnake Ridge interbed. Generally groundwater flow is toward the northeast throughout much of the 200 West Area. Graham et al. (1981, 1984) report transmissivity values of 0.7 to $108 \mathrm{~m}^{2} /$ day ( 8 to $1,165 \mathrm{ft}^{2} /$ day) for the Rattlesnake Ridge interbed.

The Rattlesnake Ridge aquifer is separated from the overlying uppermost unconfined aquifer system by the Elephant Mountain Member of the Saddle Mountains Basalt. The dense interior of this basalt has low-hydraulic conductivities $(0.009 \mathrm{~m} /$ day $[0.03 \mathrm{ft} / \mathrm{day}])$. The surface of the Elephant Mountain Member dips south-southeast toward the axis of the Cold Creek syncline from a high just north of the 200 East Area.

The suprabasalt aquifer beneath the S-26 Crib is contained within Ringold Formation units $A$ and $E$, the lower mud unit, and the lower portion of the Plio-Pleistocene unit. These strata exhibit locally confined to unconfined conditions caused by fine intervals and cemented zones. The saturated thickness of the unconfined aquifer is approximately $107 \mathrm{~m}(350 \mathrm{ft})$ beneath the crib. Hydraulic conductivities for the gravels and sands of units $A$ and $E$ range from 0.02 to $61 \mathrm{~m} /$ day $(0.06$ to $200 \mathrm{ft} /$ day). A mean hydraulic conductivity of $1.58 \times 10^{-5} \mathrm{~m} /$ day $\left(5.19 \times 10^{-5} \mathrm{ft} /\right.$ day $)$ is reported for the lower mud unit (Last et a1. [1989]; Connelly et al. [1992]).

In the immediate vicinity of the $S-26 \mathrm{Crib}$, the water table is within the Plio-Pleistocene unit (see Figure 13). The Plio-Pleistocene unit is approximately $12 \mathrm{~m}(40 \mathrm{ft})$ thick with the top of the unit dipping to the south-southwest. The Plio-Pleistocene unit is within the unsaturated zone to the north, but the lower contact dips below the water table in the area of the crib. Pedogenic $\mathrm{CaCO}_{3}$-cemented horizons within the interval may create localiy perched conditions. However, lateral discontinuities such as pinchouts and dikes within this interval suggest perched zones, if they exist, will be of relatively local extent. No perched water was reported by Last et al. (1989) above this unit although it is encountered el sewhere in the southern 200 West Area.

The thickness of the unsaturated zone beneath the S-26 Crib is approximately $67 \mathrm{~m}(220 \mathrm{ft})$ and consists of the upper portion of the PlioPleistocene unit and the lower fine unit of the Hanford formation. Recent investigations at the 216-U-14 Ditch indicate significant perching of water occurs locally within the interbedded sands and silts of the lower unit. Experience gained during studies of the 216-U-14 Ditch indicate these interbedded strata probably have a greater influence on the migration of water through the vadose zone than the underlying Plio-Pleistocene unit. Hydrologic properties for the Hanford formation are summarized in Connelly et al. (1992).

Groundwater flow in the uppermost aquifer system (near the water table) is east-southeast in the vicinity of the S-26 Crib (Figure 15) (Kasza et a1. 
1992). The groundwater flows from a large mound or lobe on the west side of the 200 West Area. The lobe, although its apex had declined and shifted eastward in recent years, is mainly due to surface discharges to the 216-U-10 Pond system (mainly 284-WB Powerplant Ponds, 216-U-14 Ditch, and 216-Z-20 Pond).

\subsection{HYDROLOGIC RESPONSES TO EFFLUENT DISPOSAL}

The water table southeast (downgradient) of the large mound on the west side of 200 West Area is a relatively uniform surface that is dipping to the southeast (see Figure 15). No irregularities exist near the S-26 Crib. Furthermore, the water level in well 299-W27-1 (the well adjacent to the S-26 (rib) is consistent with the regional water table. This indicates that the amount of wastewater discharged at the S-26 Crib and the nearby 2607-W6 Septic Tank and Drain Field (see Figure 3) are insufficient to form a discernable mound.

Discharged wastewater to the S-26 Crib is decreasing with time and will cease in 1995. Therefore, the formation of a future groundwater mound at the S-26 Crib site is unlikely assuming the continued decrease in the quantities of wastewater being discharged into the crib.

Because only one well exists near the S-26 Crib and water level measurements are consistent with the regional water table, it is difficult to determine if the wastewater discharged at the crib influences the groundwater other than to say that the water is of insufficient quantity to form a mound. Consequently, it is only possible to speculate on the nature of the groundwater conditions beneath the crib. Based on experience el sewhere at the Hanford Site, the following is a very general conceptualization of water movement through the ground beneath the crib.

When wastewater from the $S-26$ Crib is sufficient enough to saturate the soil beneath the crib, it percolates down into the uppermost sediment unit at the crib site, a silty and sandy unit that represents the interbedded sandand silt-dominated facies of the Hanford formation. Significant lateral spreading may occur in this fine-grained unit. Because lateral discontinuities, such as pinchouts and clastic dikes, are common in the siltrich horizons, lateral spreading is probably limited on individual beds. However, because multiple silt-rich horizons and the cumulative thickness of this interbedded interval are present, lateral spreading may be quite pronounced through the entire interval. Lateral spreading of moisture may al so occur on the underlying Plio-Pleistocene interval, which is known to have many discontinuous $\mathrm{CaCO}_{3}$-cemented horizons.

If any perching of the downward-migrating wastewater occurs, the amount will probably be minimal because of the discontinuous nature of the silt-rich layers in the Hanford formation and the intermittent $\mathrm{CaCO}_{3}$-cemented layers in the Plio-Pleistocene interval. Furthermore, if any perching occurs in the silt-rich layers of the Hanford formation, the preferential flow direction is unknown because the bedding is fairly horizontal. However, any perching that takes place on top, or within, the Plio-Pleistocene interval may cause groundwater at those perched layers to flow to the southeast because the 
WHC-EP-0690

This page intentionally left blank. 





interval generally dips that direction. If perched groundwater does flow to the southeast, it will be flowing in a similar direction as groundwater immediately beneath the water table (southeast).

\subsection{GROUNDWATER QUALITY}

\subsubsection{6-S-26 Crib Groundwater Quality}

Groundwater analyses data from well 299-W27-1 (at the S-26 Crib) give an indication of the local groundwater quality, as well as potential local influences from the $\mathrm{S}-26 \mathrm{Crib}$. Appendix $\mathrm{A}-\mathrm{I}$ lists results of groundwater analyses data for all groundwater samples collected from well 299-W27-1 since the well and crib were installed (1984) through July 1993.

Tabile 12 summarizes Appendix A-1 by listing the constituents detected in the analyses. The table summarizes the highest concentration measured for the parameters listed. This approach considers the most conservative, worst-case estimate for potential groundwater contamination. The range of values for each parameter that have been measured over time can be found in Appendix A-1. More than 30 constituents have been detected since 1984, of which 12 were found in concentrations greater than those in background wells (Johnson 1993b). The constituents detected were calcium, gross beta, magnesium, nitrate, potassium, selenium, sodium, strontium (nonradiological), sulfate, total organic carbon, uranium (nonradiological), and vanadium. Five constituents were found in concentrations that exceeded regulatory limits (see Table 12 for limits and regulations). They are chloroform, gross alpha, nitrate, selenium, and tritium.

Four of the five constituents that were found in concentrations exceeding regulatory limits are found in major plumes in the southeastern portion of the 200 West Area (nitrate, chloroform, tritium, and gross alpha)

(Section 4.3.2.1). These constituents are from upgradient sources and are not related to the S-26 Crib. Selenium, however, is not associated with a known plume in the 200 West Area (Ford 1993). It is also not detected in the effluent discharged to the crib (see Section 3.0). However, the detection limit used for effluent analyses, 500 parts per billion (ppb), is too high to be certain that selenium is not present in the effluent stream. Comparable groundwater sample analyses for wel1 299-W27-1, use a detection limit of $10 \mathrm{ppb}$, which is an order of magnitude less than the effluent detection limit. Therefore, it is unknown at this time if the effluent stream is the source of the selenium.

Several of the chemical parameter analytical results were plotted for the S-26 Crib. Plots of effluent chemistry (for the $S-26$ Crib), groundwater chemistry (for well 299-W27-1), and associated Hanford Site Background Average Values for the unconfined aquifer (Johnson 1993b) were created for several key parameters. These plots are shown and discussed in Appendix B. The plots show a difference in effluent chemistry versus groundwater chemistry. Figure 16 shows two groundwater quality indicator parameters, (a) pH and (b) specific conductance (conductivity). Figure 17 shows anion parameters (a) nitrate and (b) sulfate, and Figure 18 shows metal parameters (a) selenium and (b) total uranium. In most cases, the effluent chemistry was lower in 
Table 12. Constituents Detected - Groundwater Monitoring Data for Well 299-W27-1. (2 sheets)

\begin{tabular}{|c|c|c|c|c|c|c|c|}
\hline Constituent & Resu1t & Units & Background $^{6}$ & $E B$ & Limit $^{c}$ & $E L$ & Date $^{d}$ \\
\hline Alkal inity & 148,000 & $\mathrm{ppb}$ & $133,717 \pm 29,399$ & -- & - & -- & $8 / 18 / 88$ \\
\hline Barium (f) & 41 & $\mathrm{ppb}$ & $41 \pm 20$ & -- & 1,000 (WWQS) & -- & $10 / 15 / 88$ \\
\hline Calcium (f) & 55,000 & ppb & $38,542 \pm 11,023$ & $Y$ & -- & -- & $3 / 9 / 87$ \\
\hline Cesium-137 & 9 & $\mathrm{pCi} / \mathrm{L}$ & -- & -- & $120(1 / 25 \mathrm{DCG})$ & -- & $4 / 15 / 85$ \\
\hline Chloride & 17,400 & $\mathrm{ppb}$ & $8,848 \pm 7,723$ & -- & 250,000 (WWQS) & -- & $3 / 9 / 87$ \\
\hline Chloroform & 14 & ppb & -- & -- & 7 (WWQS) & $Y$ & $4 / 12 / 90$ \\
\hline Cobalt-60 & 8 & $\mathrm{pCi} / \mathrm{L}$ & -- & -- & $200(1 / 25$ DCG $)$ & -- & $10 / 9 / 84$ \\
\hline Fluoride & 400 & $\overline{p p b}$ & $437 \pm 131$ & -- & 4,000 (WWQS) & $\overline{--}$ & $\begin{array}{c}12 / 29 / 92 \text { and } \\
4 / 12 / 93\end{array}$ \\
\hline Gross alpha & 16 & $\mathrm{pCi} / \mathrm{L}$ & -- & -- & 15 (WWQS) & $y$ & $12 / 6 / 84$ \\
\hline Gross beta & 38 & $\mathrm{pCi} / \mathrm{L}$ & $7.1 \pm 2.6$ & $Y$ & 50 (WNQS) & -- & $10 / 9 / 84$ \\
\hline Potassium (f) & 6,550 & ppb & $4,993 \pm 1,453$ & $Y$ & -- & -- & $3 / 9 / 87$ \\
\hline Ruthen ium-106 & 102 & $\mathrm{pC} i / \mathrm{L}$ & -- & -- & $240(1 / 25$ DCG $)$ & -- & $7 / 23 / 87$ \\
\hline Selenium (f) & 54 & $\mathrm{ppb}$ & $<5$ & $Y$ & 10 (WWQS) & $Y$ & $\begin{array}{c}3 / 9 / 87 \text { and } \\
4 / 17 / 87\end{array}$ \\
\hline Silicon & 14,400 & $\mathrm{ppb}$ & $18,152 \pm 4,974$ & -- & -- & -- & $1 / 11 / 90$ \\
\hline Sodium & 39,600 & $\mathrm{ppb}$ & $15,774 \pm 6,784$ & $Y$ & -- & -- & $3 / 9 / 87$ \\
\hline $\begin{array}{l}\text { Specific } \\
\text { conductance }\end{array}$ & 580 & $\mu m h o s / \mathrm{cm}$ & $344 \pm 83$ & $Y$ & -- & -- & $4 / 17 / 87$ \\
\hline
\end{tabular}


Table 12. Constituents Detected - Groundwater Monitoring Data for We11 299-W27-1. (2 sheets)

\begin{tabular}{|c|c|c|c|c|c|c|c|}
\hline Constituent & Result & Units & Background $^{6}$ & EB & Limit $^{c}$ & EL & Date $^{d}$ \\
\hline $\begin{array}{l}\text { Strontium } \\
(f, n r)\end{array}$ & 264 & ppb & $164 \pm 47$ & $Y$ & -- & -- & $10 / 15 / 87$ \\
\hline Strontium-90 & 2 & $\mathrm{pCi} / \mathrm{L}$ & - & -- & 8 (WWQS) & -- & $4 / 15 / 85$ \\
\hline Sulfate & 63,500 & ppb & $30,605 \pm 22,611$ & $Y$ & 250,000 (WWQS) & -- & $7 / 24 / 87$ \\
\hline $\begin{array}{l}\text { Total organic } \\
\text { carbon }\end{array}$ & 3,850 & ppb & $519 \pm 367$ & $Y$ & $\overline{--}$ & -- & $7 / 24 / 87$ \\
\hline $\begin{array}{l}\text { Total organic } \\
\text { hal ides (as C } 1 \text { ) }\end{array}$ & 20 & ppb & $<20$ & -- & $\overline{--}$ & -- & $12 / 29 / 92$ \\
\hline Tritium & 637,000 & $\mathrm{pCi} / \mathrm{L}$ & -- & -- & 20,000 (WWQS) & $Y$ & $10 / 8 / 85$ \\
\hline Uranium (nr) & 14 & $\mathrm{pCi} / \mathrm{L}$ & $1.7 \pm 1.2$ & $Y$ & - & -- & $5 / 16 / 88$ \\
\hline Uranium-234 & 5 & $\mathrm{pCi} / \mathrm{L}$ & - & -- & $20(1 / 25$ DCG $)$ & -- & $12 / 15 / 88$ \\
\hline Uranium-238 & 5 & $\mathrm{pCi} / \mathrm{L}$ & -- & -- & $24(1 / 25$ DCG $)$ & -- & $4 / 12 / 93$ \\
\hline Vanadium & 24 & ppb & $9 \pm 4$ & $Y$ & - & -- & $8 / 18 / 88$ \\
\hline Zinc & 37 & $\mathrm{ppb}$ & $95 \pm 140$ & -- & 5,000 (WWQS) & -- & $2 / 3 / 92$ \\
\hline$\overline{\mathrm{pH}}$ & 9 & -- & $7.57 \pm 0.29$ & $Y$ & 6.5 to 8.5 (MQS) & $Y$ & $4 / 12 / 93$ \\
\hline
\end{tabular}

Highest recorded result from the Hanford Environmental Information System (HEIS) database, results through July 1993.

Johnson 1993b.

c WWQS = Washington Water Quality Standards, Washington Administrative Code 173-200;

$1 / 25 D C G=1 / 25$ Derived Concentration Guidel ines, WHC-CM-7-5, Section 8.0.

Date sample collected.

$E B=$ Exceed background.

$E L=$ Exceed limit.

$f=$ Filtered

$n r=$ Nonradiological

$\mathrm{pC} i / \mathrm{L}=$ Picocuries per liter .

ppb = Parts per billion. 
Figure 16. Concentration Plots of 216-S-26 Crib Effluent, Well 299-W27-1 Groundwater, and Hanford Site Background Average for the Unconfined Aquifer (Johnson 1993b) for (a) $\mathrm{pH}$ and (b) Specific Conductance.

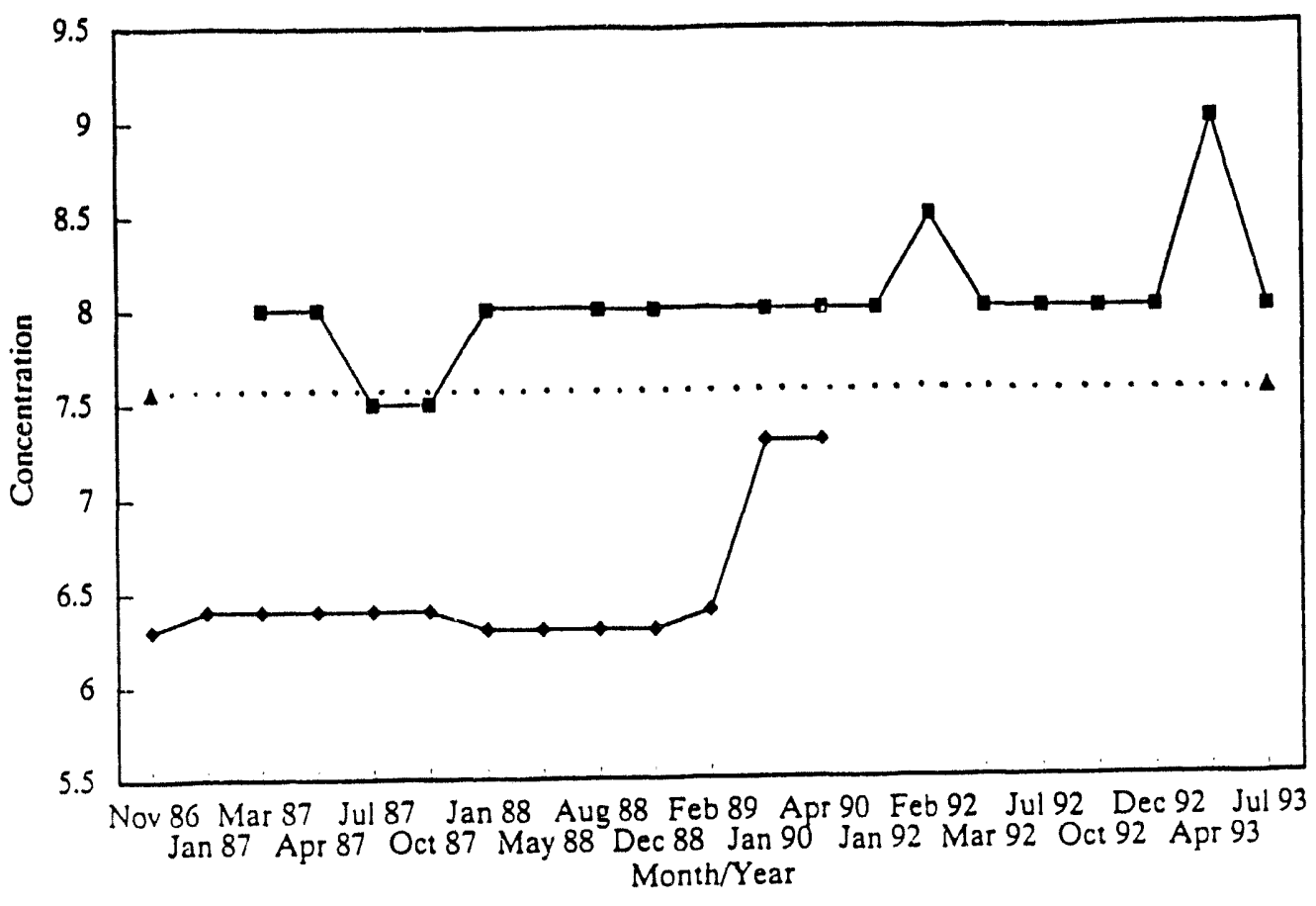

$\rightarrow \mathrm{pH}-\mathrm{GW} \rightarrow \mathrm{pH}-\mathrm{EF} \rightarrow \mathrm{pH}-\mathrm{BA}$

$\mathrm{GW}=$ Groundwater. $\overrightarrow{E F}=$ Effluent. $\overrightarrow{B A}=$ Background average for unconfined aquifes.

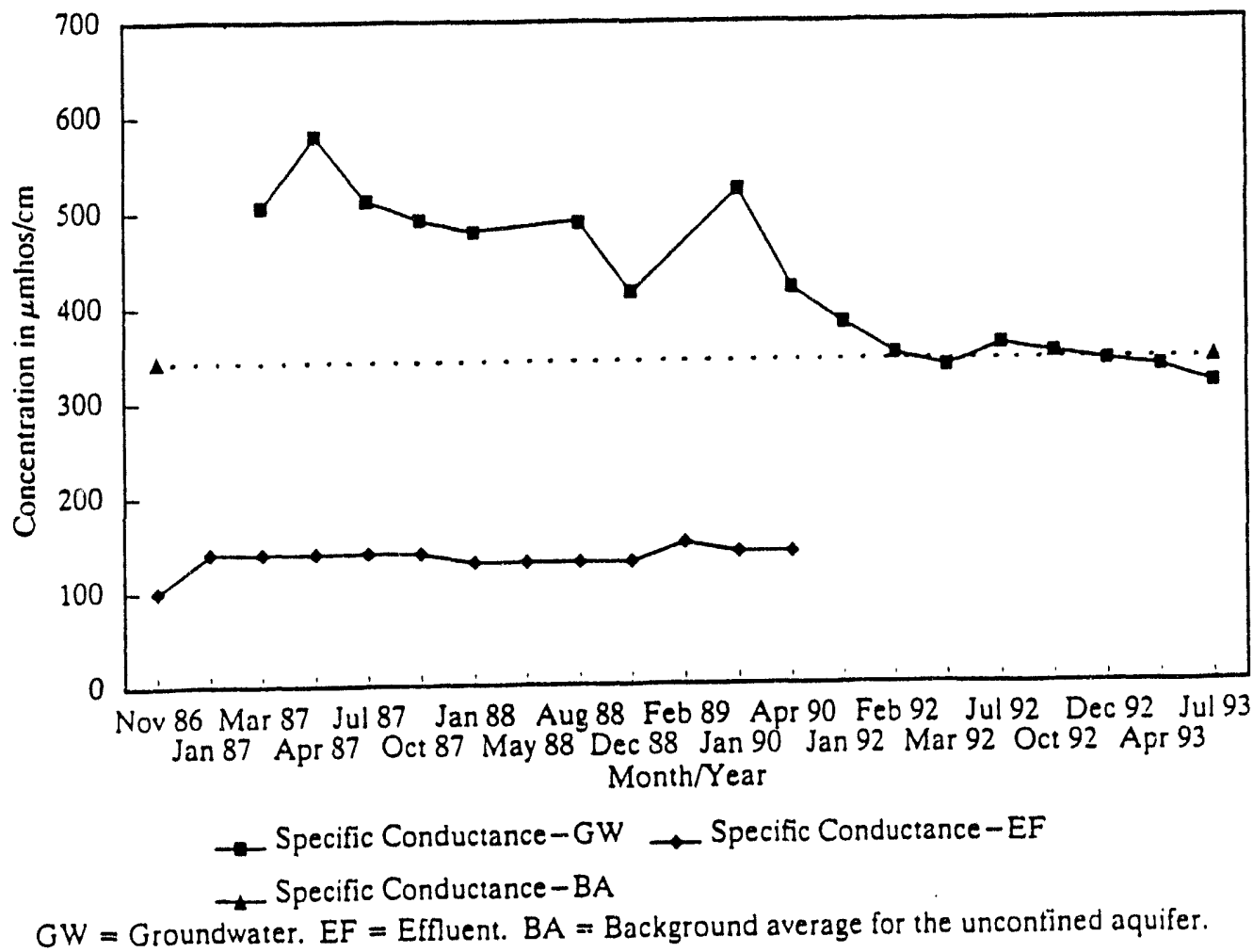


Figure 17. Concentration Plots of 216-S-26 Crib Effluent, Well 299-W27-1 Groundwater, and Hanford Site Background Average for the Unconfined Aquifer (Johnson 1993b) for (a) Nitrate and (b) Sulfate.

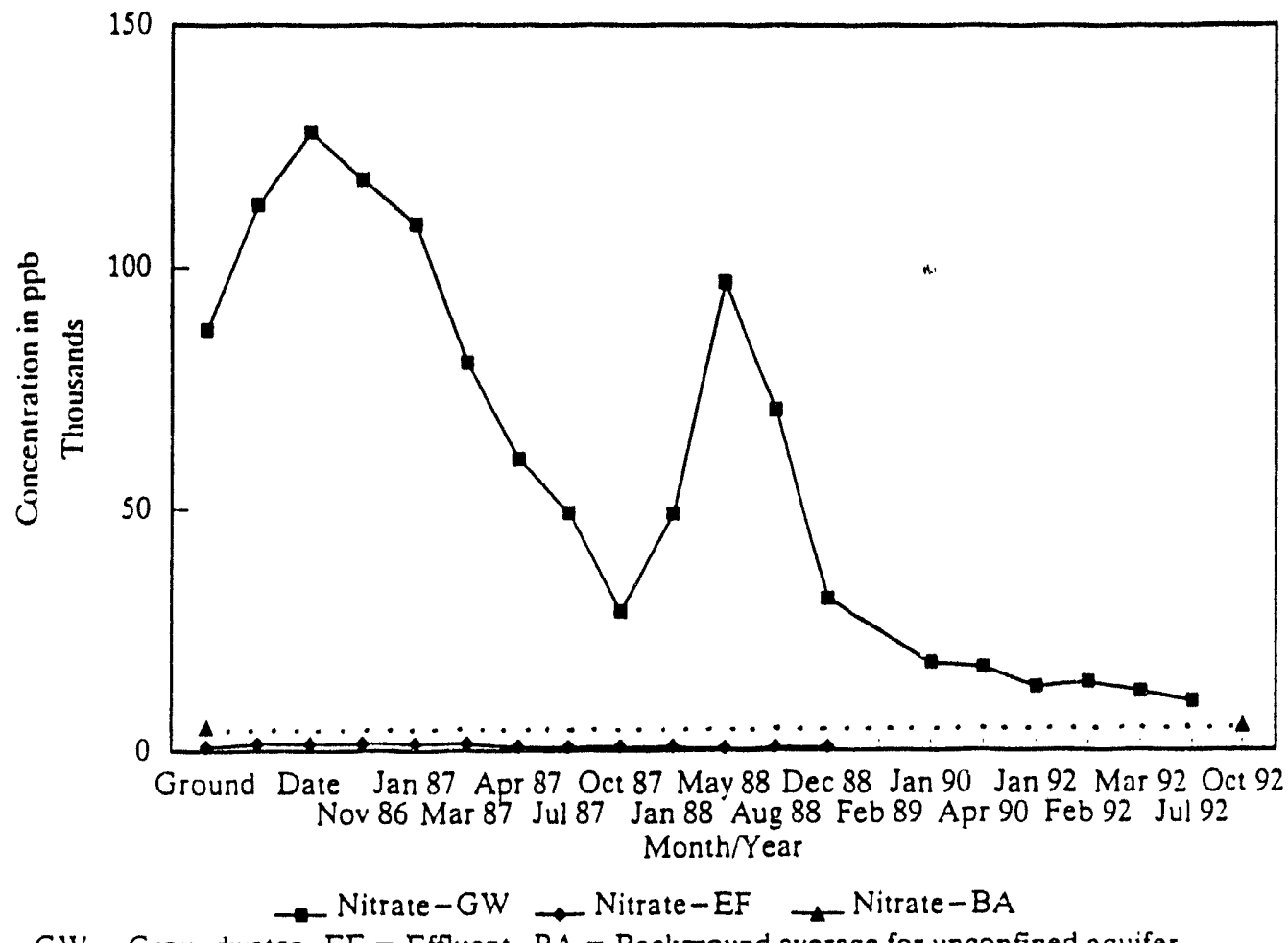

$\mathrm{GW}=$ Groundwater. $\mathrm{EF}=$ Effluent. $\mathrm{BA}=$ Background average for unconfined aquifer.

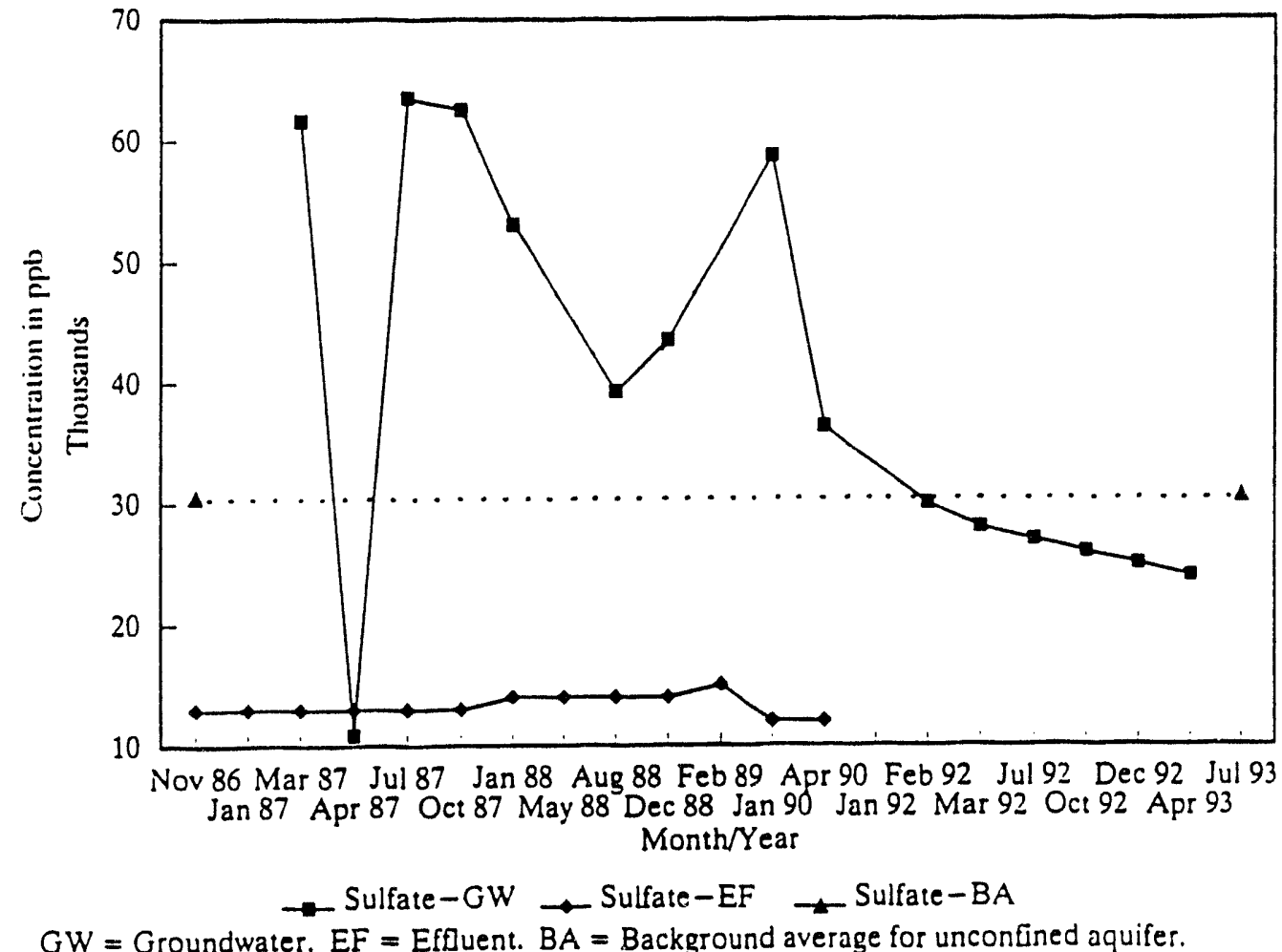

$\mathrm{GW}=$ Groundwater. $\mathrm{EF}=$ Efluent. $\mathrm{BA}=$ Background average for unconfined aquifer. 
Figure 18. Concentration Plots of 216-S-26 Crib Effluent, Well 299-W27-1 Groundwater, and Hanford Site Background Average for the Unconfined Aquifer (Johnson 1993b) for (a) Selenium and (b) Total Uranium.



$\rightarrow$ Selenium-GW $\rightarrow$ Selenium-EF $\rightarrow$ Selenium-BA

$G W=$ Groundwater. $E F=$ Effluent. $B A=$ Background average for unconfined aquifer.

Note: 'Effluent analytical limit of detection (all three samples) is too high to determine if inium is present.



Total Uranium-GW $\rightarrow$ Total Uranium-EF $\rightarrow$ Total Uranium-BA

$\mathrm{GW}=$ Groundwater. $E F=$ Effluent. $\mathrm{BA}=$ Background average for unconfined aquifer. 
concentration than both the background unconfined aquifer and groundwater concentrations. Furthermore, the groundwater concentrations were higher than the average background concentration for the unconfined aquifer. This suggests that the effluent is not the source of many of the constituents seen in elevated concentrations in the groundwater. To determine the source $(s)$ of the elevaded concentrations seen in the groundwater, additional analytical results for several monitoring wells upgradient from the $\mathrm{S}-26 \mathrm{Crib}$ were examined (Section 4.3.2.2).

\subsubsection{Upgradient Groundwater Quality}

4.3.2.1 200 West Area Groundwater Contaminant Plumes. Examination of contaminant plume maps (Figures 19 through 22) and comparison to regulatory limits indicate four major contaminant piumes may be present beneath the S-26 Crib (Connelly et a1. 1992; Ford 1993). They are nitrate, chloroform, tritium, and gross alpha. The apparent groundwater flow direction beneath the crib is from the northwest to the southeast. The closest well immediately upgradient (299-W22-21) is approximately $503 \mathrm{~m}(1,650 \mathrm{ft})$ to the northwest. However, theire is one well due north of the crib (299-W22-20) about $122 \mathrm{~m}$ $(400 \mathrm{ft})$. The nearest well downgradient of the crib (other than 299-W27-1 located at the crib, 699-32-72) is approximately $550 \mathrm{~m}(1,800 \mathrm{ft})$ to the southeast. The concentrations of the four constituents forming plumes beneath the crib site are given below. Section 4.3 .2 .2 provides more detail on the probable sources.

- Nitrate is found in highly variable concentrations in several major plumes throughout most of the 200 West Area (Figure 19) indicating many possible sources. The plume beneath the $S-26$ Crib is smaller and separate from the major plumes to the north. The small plume at the site has a concentration approximately equal to the drinking water standard ( 45 parts per million [ppm]).

- The chloroform plume map (Figure 20) indicates major sources of chloroform on the west side of the 200 West Area. However, there is a small plume of chloroform in the immediate vicinity of the $\mathrm{S}-26 \mathrm{Crib}$, as it has been detected in the well at the crib (299-W27-1) and in the well (299-W22-20) immediately to the north. In these two wells, chloroform was detected in concentrations just slightly higher than the Washington Water Quality Standard (WWQS) of 7 ppm.

- A large tritium plume extends from the area to the northwest of the S-26 Crib (southwest portion of the 200 West Area), passes mainly north of the crib site, and extends southeastward, eastward, and northeastward (Figure 21). Its highest concentration is approximately $450 \mathrm{~m}(1,500 \mathrm{ft})$ northeast of the crib site where it is over 6,000,000 picocuries per liter $(\mathrm{pCi} / \mathrm{L})$. Near the $\mathrm{crib}$ it is much lower in concentration at approximately $4,000 \mathrm{pCi} / \mathrm{L}$.

- Gross alpha plumes are detected at several places in the 200 West Area (Figure 22). The largest and most concentrated plume is in the southeastern portion of the 200 West Area. Another major plume is located in the southwestern portion of the 200 West Area, and a 
WHC-EP-0690

Figure 19. Nitrate Plume Map for the 200 West Area.




Figure 20. Chloroform Plume Map for the 200 West Area.

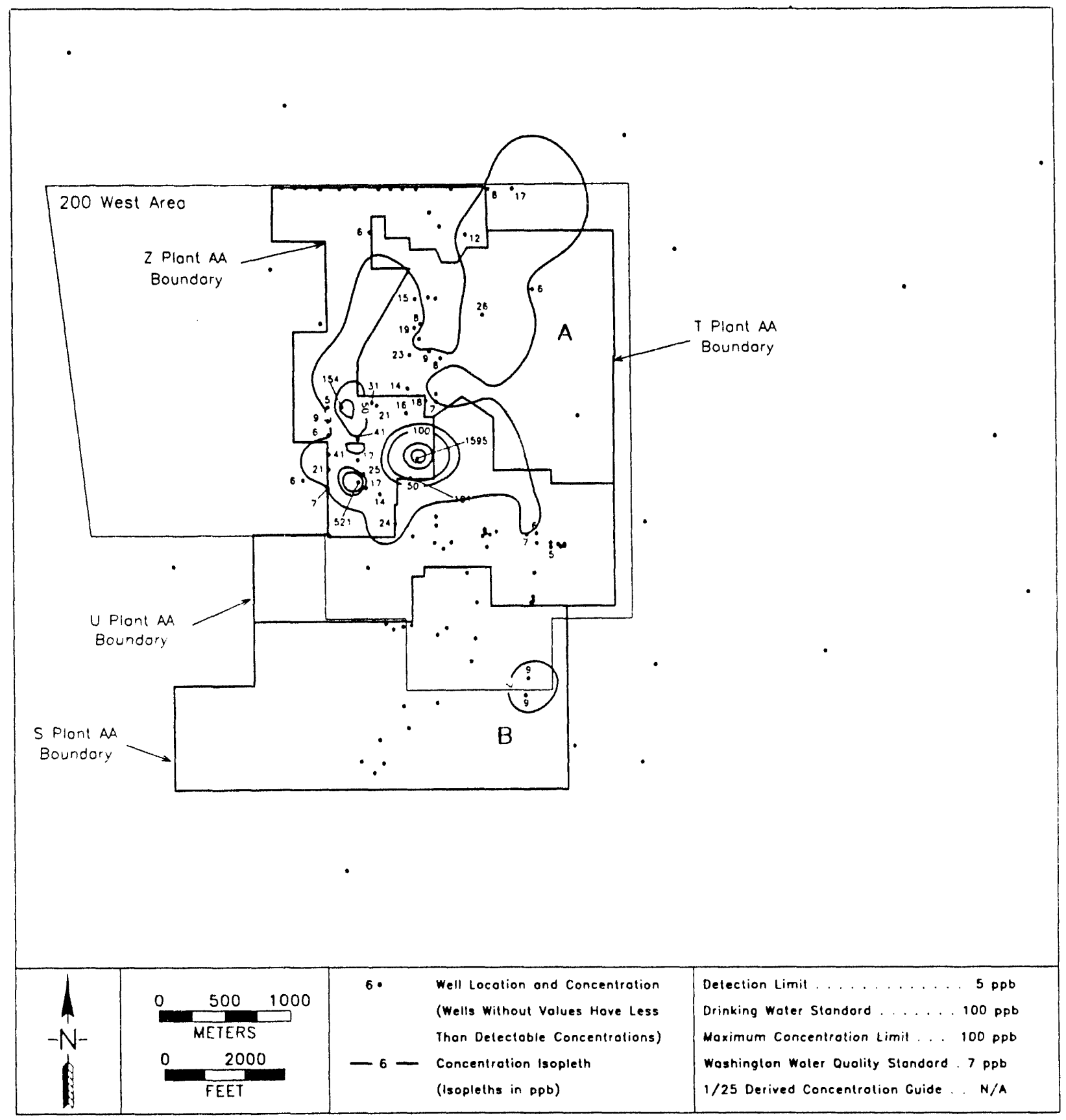


Figure 21. Tritium Plume Map for the 200 West Area.

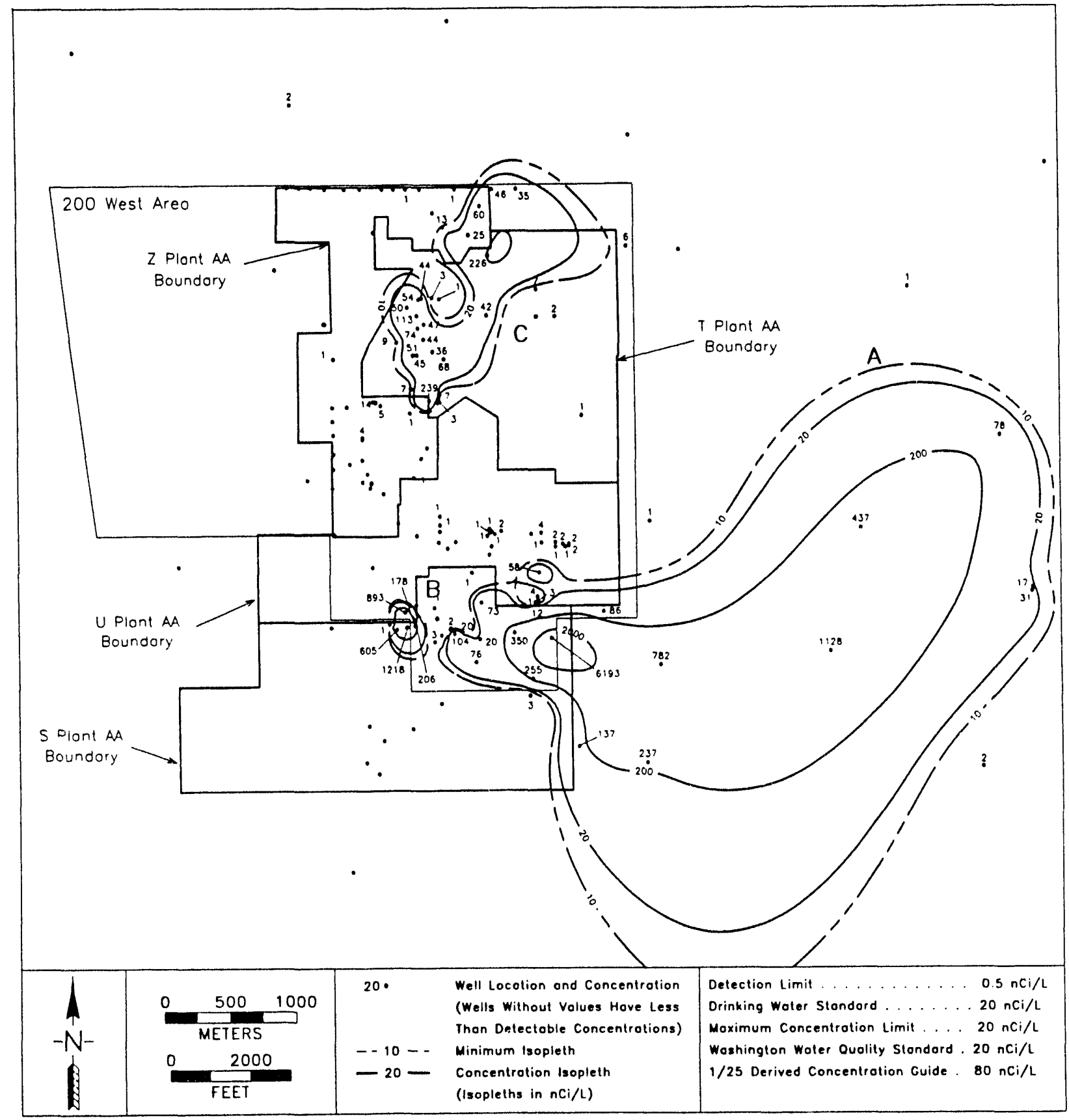


Figure 22. Gross Alpha Plume Map for the 200 West Area.




tongue extends to the southeast through the area of the crib. Concentrations upgradient are as high as $40 \mathrm{pCi} / \mathrm{L}$, but near the crib the concentration is approximately $8 \mathrm{pCi} / \mathrm{L}$.

4.3.2.2 Upgradient Groundwater Quality and Sources of Contaminants. Groundwater chemistry data from several wells located to the north and northwest of the S-26 Crib site were examined to determine the overall quality of groundwater upgradient of the crib area. The Hanford Environmental Information System (HEIS) database was queried for analytical results from 1986 to July 1993, to give an indication of historical as well as current groundwater conditions. Appendix A-2 lists results of the groundwater analyses data for selected upgradient groundwater monitoring wells from 1986 through July 1993. Table 13 gives the potential contamination sources and accompanying wells that were examined. Figure 23 shows the well and disposal site locations.

The list of parameters used to determine groundwater conditions in upgradient wells was arrived at using data from the S-26 Crib groundwater monitoring well (299-w27-1). Constituents of interest, known contaminants present in plumes in the area, groundwater quality indicators, and other related chemical parameters used were as follows:

- Groundwater quality indicators--pH and specific conductance

- Cations--Calcium and sodium

- Anions--Nitrate, sulfate, and chloride

- Metals--Barium, selenium, strontium, vanadium, and zinc

- Radiological parameters--Total uranium, tritium, strontium-90, gross alpha, and gross beta.

Plots of groundwater chemistry and associated Hanford Site Background Average Values for the unconfined aquifer (Johnson 1993b) were created for the same key parameters as used for the plots in Section 4.3.1. These plots are shown and discussed in Appendix B. Several trends were noted when all the plots were examined together. For most parameters, Well 299-W22-20 was higher in concentration than the background average for the unconfined aquifer. Well 299-W22-12 was below the background average for most parameters. The sources of contamination nearest Well 299-W22-20 are the 216-S-1, 216-S-2, 216-S-7, 216-S-13, and 216-S-25 Cribs to the northwest and the 216-S-22 Crib and 216-S-12 Trench to the north (see Figure 23). The majority of the wastes disposed of to these facilities (see Table 1) were radioactive (mainly uranium), acidic (nitric and sulfuric acid), and contained sodium, sodium dichromate, nitrate, ammonium nitrate, ferrous ammonium sulfate, and sodium sulfate (DOE-RL 1992; Jones 1993). Concentrations of nitrate, sulfate, chloride, total uranium, tritium, gross alpha and beta, and several related metals (vanadium, strontium, and potentially selenium) remain above background in the groundwater upgradient of the S-26 Crib. However, the trend appears to be a decrease in concentration over time. Figures 24 and 25 show this relationship for nitrate and total uranium. Most of the elevated concentrations are related to the past-practice disposal sites in the vicinity (see Figure 23). 
Table 13. Potential Contamination Sources and Nearby Groundwater Monitoring Wells.

\begin{tabular}{|c|c|}
\hline Potential contamination source & Nearby well \\
\hline $216-S-1$ and 216-S-2 Cribs & $299-W 22-10$ \\
\hline $216-S-7$ Crib & $299-W 22-12$ \\
\hline $216-S-13$ Crib & $299-W 22-21$ \\
\hline $216-S-20$ Crib & $299-W 22-20$ \\
\hline $216-S-22$ Crib & $299-W 22-19$ \\
\hline $216-S-25$ Crib & $299-W 23-9$ \\
\hline $216-S-12$ Trench & $299-W 22-19$ and 299-W22-20 \\
\hline $216-S-10 D$ Ditch & $299-W 26-11$ and 299-W-26-12 \\
\hline $2607-W 6$ and 2607-WZ Septic Tanks \\
and Drain Fields
\end{tabular}


Figure 23. Location of Nearby Facilities, Past-Practice Disposal

Sites, and Selected Monitoring Wells in the Vicinity of the 216-S-26 Crib.

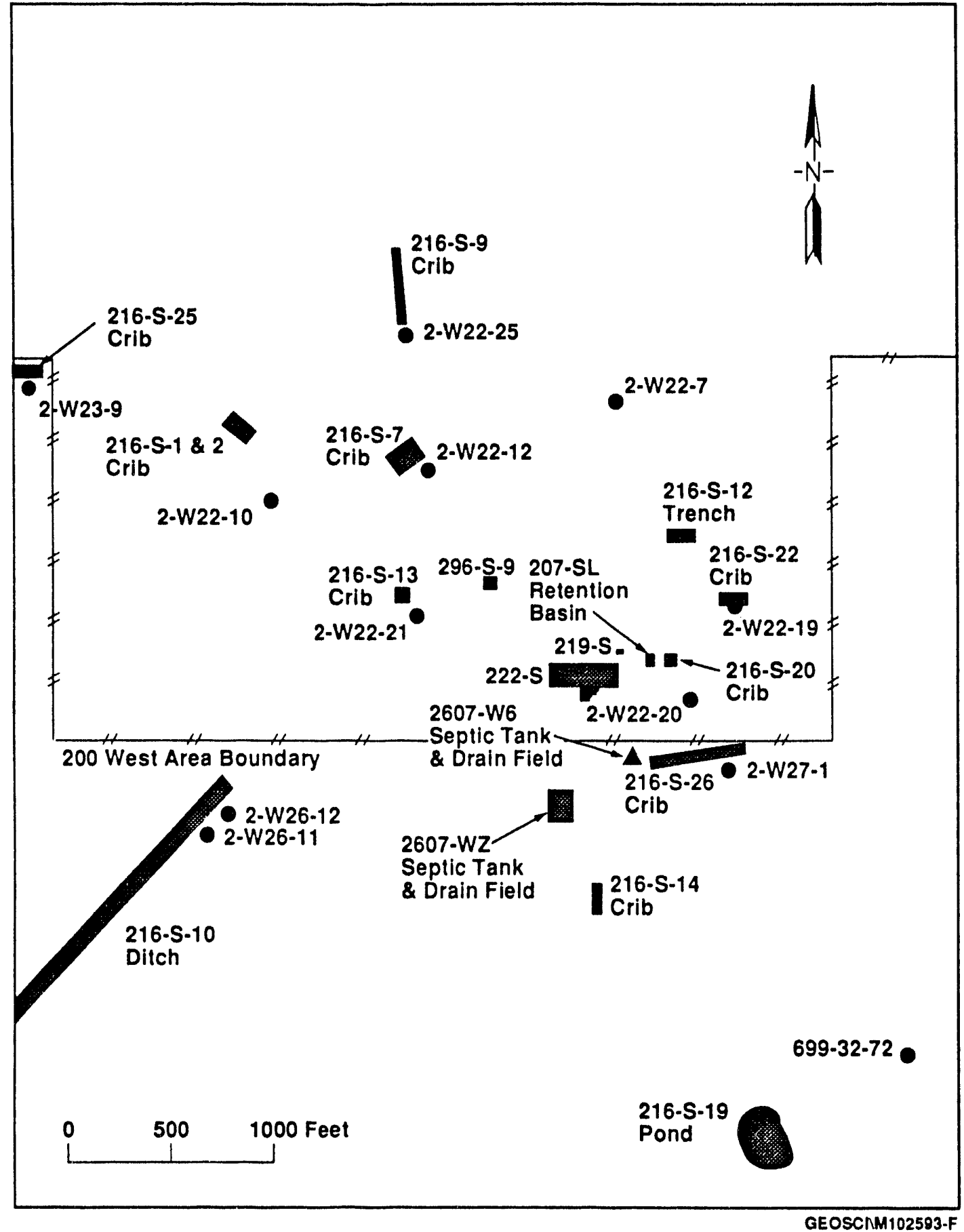


Figure 24. Concentration Plots of Nitrate in (a) 216-S-26 Crib Effluent, Well 299-W27-1 Groundwater, and Hanford Site Background Average for the Unconfined Aquifer (Johnson 1993b) and (b) Upgradient Monitoring Wells Near Disposal Sites in the Vicinity of the 216-S-26 Crib.

Figure 25. Concentration Plots of Total Uranium in (a) 216-S-26 Crib Effluent, Well 299-W27-1 Groundwater, and Hanford Site Background Average for the Unconfined Aquifer (Johnson 1993b) and (b) Upgradient Monitoring Wells Near Disposal Sites in the Vicinity of the $216-5-26$ crib.

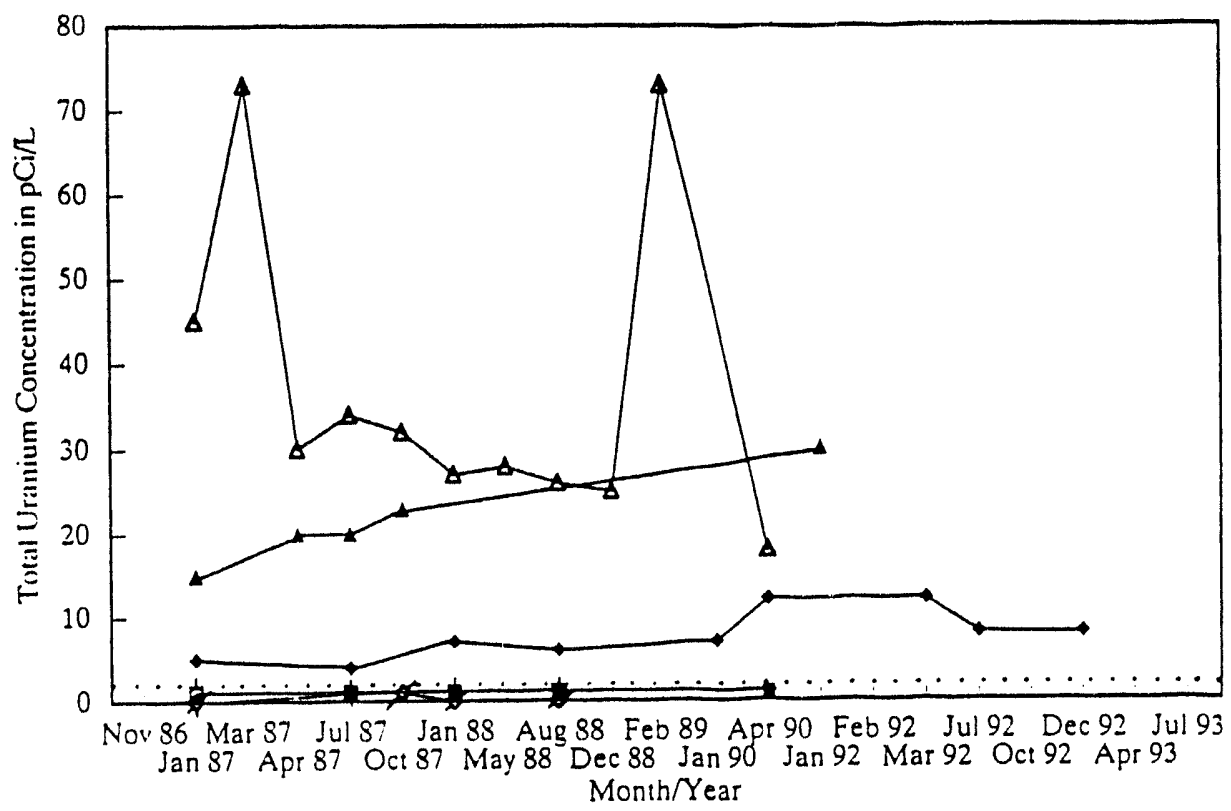

$\rightarrow$ Well W22-12 $\rightarrow$ Well W22-20 $\rightarrow$ Well W22-21

$\rightarrow$ Well W22-7 $\rightarrow$ Well W22-10 $\triangle$ Well W23-9

Note: Graph illustrates groundwater data from wells upgradient of the 216-5-26 Crib location.

Hanford site background average concentration for the unconfined aquifer is shown as a dotted line.




The sulfate, selenium, and vanadium occurrences are related, but a potential upgradient source is not obvious from the historical data (Table 1). The groundwater chemistry data plots (Figures 26, 27, and 28) for upgradient wells (e.g., 299-W22-20 and 299-W27-1), indicate that these wells are located in the path of the plume of these constituents. The most likely potential upgradient sources are the 216-S-1, 216-S-2, 216-S-7, 216-S-13, and 216-S-25 Cribs.

\subsection{SOIL COLUNN CHEMISTRY FACTORS}

Liquid wastes discharged to the S-26 Crib have contributed chemical and radioactive wastes to the soil column. These liquid wastes included effluent from the 222-S Laboratory Complex. These liquid wastes have included lowlevel radiological and chemical constituents in the past, specifically strontium-90, acetone, nitrate, nitric acid, and lesser amounts of sulfuric and hydrofluoric acids (WHC 1991). In addition to these sources, there have al so been three or more $4,200 \mathrm{~L}(1,100 \mathrm{gal})$ tanker truck discharges of Plutonium Finishing Plant (PFP) Complex caustic rinsate to the S-26 Crib from 1986 to 1987 . These discharges had pH values of approximately 12.5 , which is the high end of the Washington State Dangerous Waste regulation (WAC 173-303) range (greater than 2 and less than 12.5) for waste to be considered noncorrosive and therefore unregulated. This $\mathrm{pH}$ exceeds the WWQS criteria for groundwater $\mathrm{pH}$ values, which is given a range 6.5 to 8.5. After receiving the alkaline $\mathrm{pH}$ discharges, infiltration in the S-26 Crib decreased and has continued to be a problem (DOE/RL 1992). This decrease in infiltration is similar to a situation created in the 216-2-20 Crib at the PFP Complex. After similar caustic rinsate solutions from the PFP Complex were discharged to the 216-2-20 crib, its infiltration capacity also decreased. This suggests that caustic rinsate forms chemical precipitates and thereby decreases the porosity of the soil column beneath the crib (Johnson 1993a). Effluent from the 222-S Laboratory Complex facilities is generally in the 6 to $7 \mathrm{pH}$ range (see Table 8), which is slightly acidic to neutral. Subsequent effluent discharges in this $\mathrm{pH}$ range were not acidic enough to reverse this reaction and thereby unclog the near-surface sediments.

The use of detergents and decontamination chemicals in the 222-S and 222-SA laboratories and subsequent discharge of these materials in effluent to the S-26 Crib, could also effect the soil column chemistry. Early studies (Knoll 1957) snowed a marked reduction in radionuclide sorption by Hanford Site soils in the presence of laundry detergents and related decontamination chemicals. For example, 0.1 weight percent solutions of various detergents reduced distribution coefficients ( $K_{d}$ values) significantly for long-lived radionuclides such as strontium-90, cesium-137, and plutonium (Table 14). Apparently detergents either form a complex with the radionuclides or block the sorption sites on the soil.

The potential significance of the above statement is that contaminant retention properties of the soil column beneath the S-26 Crib may have been altered. Consequently, the radionuclide inventory in the soil column may be distributed over a greater depth than expected. However, it is likely that the concentrations of detergents and chemicals in the waste solutions are relatively low because of dilution. Therefore, it is likely that they have little, if any effect on the soil column chemistry. 
Figure 26. Concentration Plots of Sulfate in (a) 216-S-26 Crib Effluent, Well 299-W27-1 Groundwater, and Hanford Site Background Average for the Unconfined Aquifer (Johnson 1993b) and (b) Upgradient Monitoring Wells Near Disposal Sites in the Vicinity of the 216-S-26 Crib.

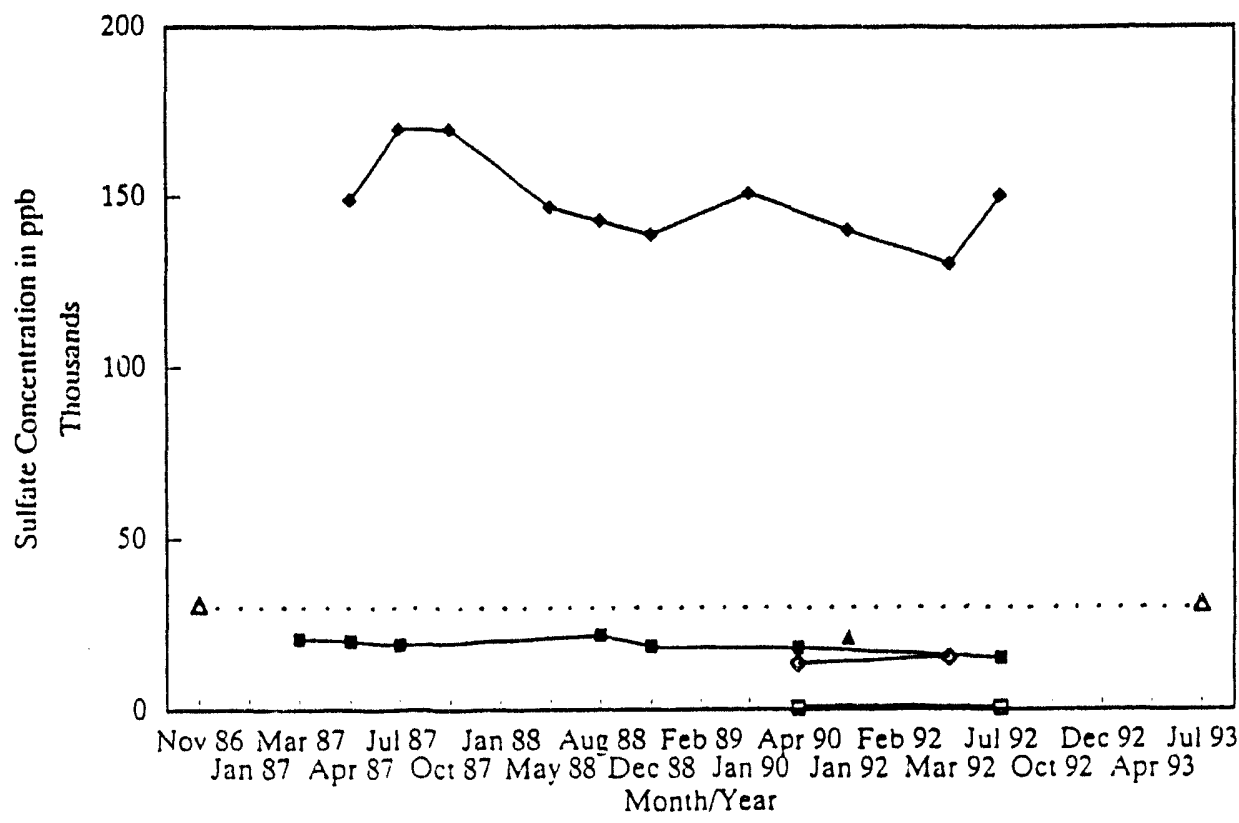

$\rightarrow$ Well W22-12



$\rightarrow$ Well W22-21

$\rightarrow$ Well W22-10

$\rightarrow$ Well W23-9

$\triangle$ Background Average

Note: Graph illustrates groundwater data from wells upgradient of the 216-S-26 Crib location.

Background Average = Hanford site background average concentration

for the unconfined aquifer and it is shown as a dotted line on the



$G W=$ Groundwater. $E F=E$ Enuent. $B A=$ Background average for unconfined aquifer . 
Figure 27. Concentration Plots of Selenium in (a) 216-S-26 Crib Effluent, Well 299-W27-1 Groundwater, and Hanford Site Background Average for the Unconfined Aquifer (Johnson 1993b) and (b) Upgradient Monitoring Wells Near Disposal Sites in the Vicinity of the 216-S-26 Crib.
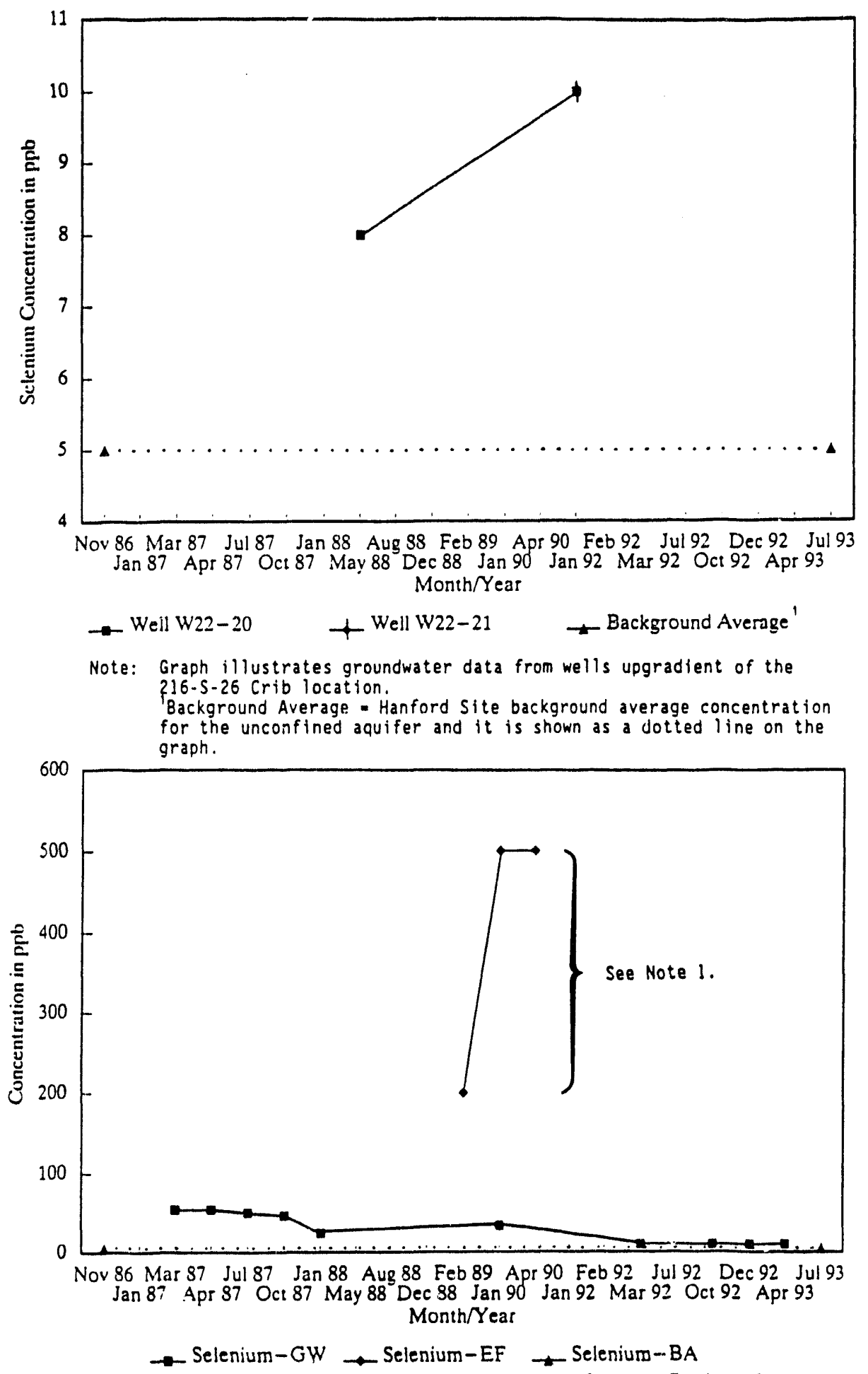

$G W=$ Groundivater. $E F=$ Etfluent. $B A=$ Background average for unconfined aquifer.

Note: 'Effluent analytical limit of detection (all three samples) is too high to determine if any selenium is present. 


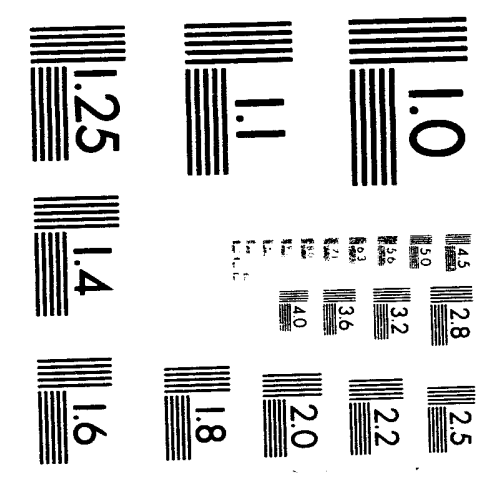




Figure 28. Concentration Plots of Vanadium in (a) 216-S-26 Crib Effluent, We11 299-W27-1 Groundwater, and Hanford Site Background Average for the Unconfined Aquifer (Johnson 1993b) and (b) Upgradient Monitoring Wells Near Disposal Sites in the Vicinity of the 216-S-26 Crib.

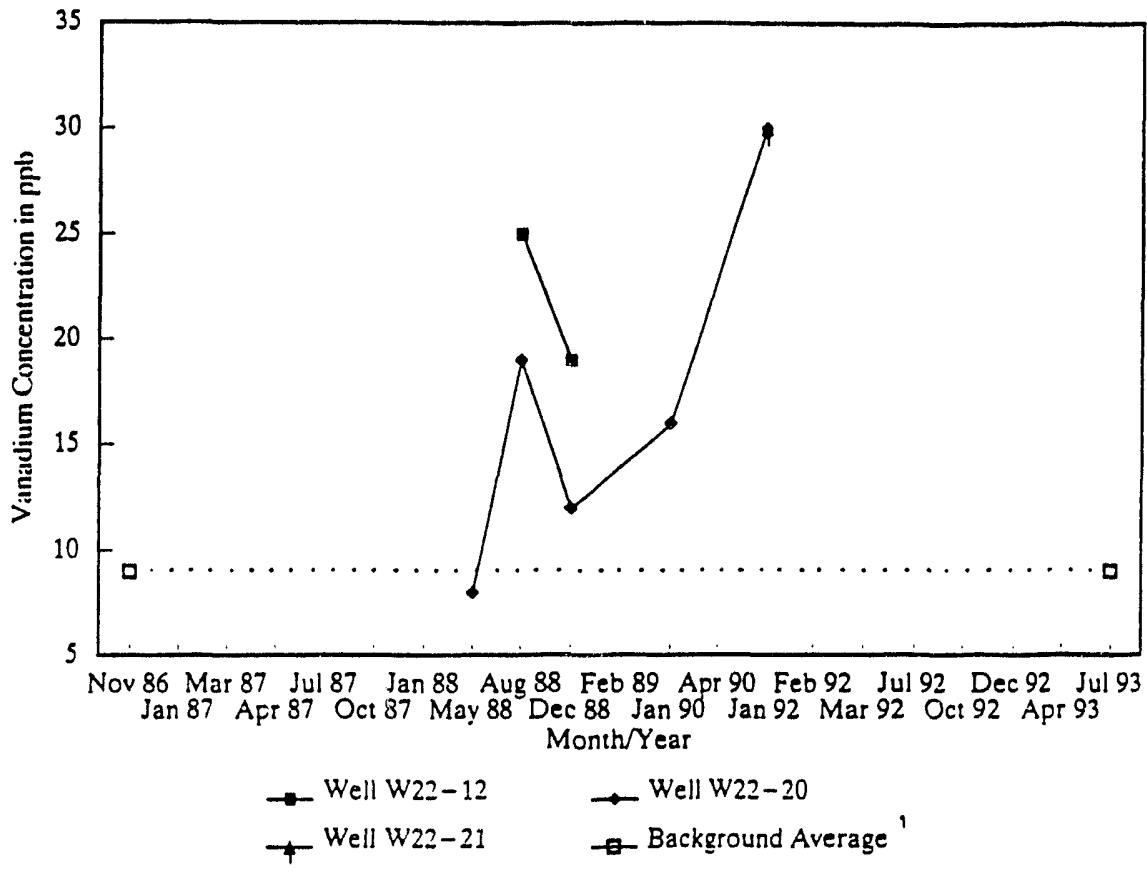

Note: Graph illustrates groundwater data from wells upgradient of the 216-5-26 Crib location.

Background Average. Hanford Site background average concentration for the unconfined aquifer and it is shown as a dotted line on the graph.



$\mathrm{GW}=$ Groundwater. $\mathrm{EF}=$ Effuent. $\mathrm{BA}=$ Background average for unconfined aquifer.

Note: 'Effluent vanadium concentration is less than the analytical limit of detection.

Groundwater analytical limit of detection (starting January 1992) is too high to determine if any vanadium is present. 
Table 14. $K_{d}$ Values for Strontium-90, Cesium-137, and Plutonium-239 in Soils Treated with Various Detergents (adapted from Knoll 1957).

\begin{tabular}{|c|c|c|c|c|c|c|c|c|c|c|c|c|c|c|c|}
\hline \multirow[b]{2}{*}{ Detergent } & \multicolumn{5}{|c|}{ Stront ium-90 } & \multicolumn{5}{|c|}{ Cesium-137 } & \multicolumn{5}{|c|}{ Plutonium-239 } \\
\hline & $\begin{array}{c}\text { pH of } \\
\text { Deter. } \\
\text { Soln. }\end{array}$ & $\begin{array}{l}\text { pH at } \\
\text { Equil. } \\
\text { with } \\
\text { Soil }\end{array}$ & $\begin{array}{l}\text { Kd of } \\
\text { Deter. } \\
\text { Soln. }\end{array}$ & $\begin{array}{c}K_{d} \text { of } \\
\text { water } \\
\text { ot } \\
\text { Equil. } \\
\text { pH }\end{array}$ & $\frac{D K}{W K_{d}}$ & $\begin{array}{l}\text { pH of } \\
\text { Deter. } \\
\text { Soln. }\end{array}$ & $\begin{array}{l}\text { pH at } \\
\text { Equil. } \\
\text { with } \\
\text { Soil }\end{array}$ & $\begin{array}{l}\text { Kof of } \\
\text { Deter. } \\
\text { Soln. }\end{array}$ & $\begin{array}{c}\text { Kof of } \\
\text { watter } \\
\text { ot } \\
\text { Equil. } \\
\text { pH }\end{array}$ & $\frac{D K_{d}}{W K_{d}}$ & $\begin{array}{c}\text { PH of } \\
\text { Deter. } \\
\text { Soln. }\end{array}$ & $\begin{array}{l}\text { pH at } \\
\text { Equil. } \\
\text { with } \\
\text { Soil }\end{array}$ & $\begin{array}{l}\text { Kd of } \\
\text { Deter. } \\
\text { Soln. }\end{array}$ & $\begin{array}{c}\text { Kof of } \\
\text { Watter } \\
\text { at } \\
\text { Equil. } \\
\text { pH }\end{array}$ & $\frac{D K}{W K_{d}}$ \\
\hline Duponal ${ }^{\circ}$ & 6.5 & 8.8 & 19.8 & 110 & 0.18 & 6.5 & 8.8 & 24 & 356 & 0.07 & 6.5 & 8.8 & 6 & 30 & 0.5 \\
\hline Lanokleen $^{6}$ & 9.7 & 8.2 & 26.0 & 72 & 0.36 & 9.7 & 8.4 & 59 & 420 & 0.14 & 9.7 & 8.4 & 7 & 42 & 0.16 \\
\hline Calgon & 8.6 & 8.4 & 3.8 & 86 & 0.04 & 8.6 & 8.4 & 60 & 420 & 0.14 & 8.6 & 8.4 & 9 & 42 & 0.21 \\
\hline $\begin{array}{l}\text { Trisodium } \\
\text { phosphate }\end{array}$ & 9.8 & 11.7 & 8.9 & 348 & 0.02 & 11.7 & 9.6 & 34 & 250 & 0.13 & 11.7 & 9.6 & 10 & 45 & 0.22 \\
\hline $\begin{array}{l}\text { Sulfamic } \\
\text { acid }\end{array}$ & 2.3 & 8.4 & 7.6 & 86 & 0.09 & 2.3 & 8.4 & 31 & 420 & 0.07 & 2.3 & 8.4 & $>160$ & 42 & $>3.8$ \\
\hline Tide $^{d}$ & 10.0 & 9.0 & 9.8 & 122 & 0.08 & 10.6 & 8.7 & 40 & 375 & 0.1 & 10.0 & 8.7 & 36 & 30 & 1.2 \\
\hline Kerful $^{e}$ & 12.0 & 10.7 & 16.6 & 270 & 0.05 & 2.1 & 8.4 & $<40$ & 420 & $\begin{array}{c}<0.0 \\
9\end{array}$ & 12.0 & 10.7 & 10 & 86 & 0.11 \\
\hline Oakite $\$ 32^{7}$ & 2.1 & 8.4 & 14.1 & 8.6 & 1.65 & 11.7 & 9.9 & 60 & 200 & 0.3 & 2.1 & 8.4 & $>160$ & 42 & $>3.8$ \\
\hline $\begin{array}{l}\text { Trigngle } \\
100\end{array}$ & 11.7 & 10.0 & 35.0 & 210 & 0.16 & 2.1 & 8.3 & $>180$ & 430 & $>0.4$ & 11.7 & 9.9 & 8 & 62 & 0.13 \\
\hline Bowlene & 2.1 & 8.3 & 9.4 & 78 & 0.12 & 12.0 & 10.9 & 25 & 65 & 0.38 & 2.1 & 8.3 & $>160$ & 45 & $>3.5$ \\
\hline Blast & 12.0 & 10.7 & 24.8 & 270 & 0.09 & 12.0 & 10.7 & 23 & 60 & 0.38 & 12.0 & 10.9 & 16 & 94 & 0.17 \\
\hline $\begin{array}{l}\text { Turco } \\
4306-8 j\end{array}$ & 2.5 & 7.0 & 4.8 & 34 & 0.14 & 2.5 & 8.0 & 427 & 480 & 0.9 & 2.5 & 8.0 & $>2,500$ & 55 & $>40$ \\
\hline
\end{tabular}

Duponal is a trademark of E. 1. dupont de Nemours \& Compeny.

Lanokleen is a trademark of West Disinfecting Company.

calgon is a trademark of Calgon, Inc.

Tide is a trademark of Proctor \& Gamble.

Kerful is a trademark of Clayton Manufacturing Compeny.

Oakite 32 is a trodemark of Oakite Products Company.

Triangle 100 is a trademark of L. H. Butcher Company.

Bowlene is a trademark of Climaline Company.

$\mathrm{Blast}$ is a tredemark of DuBois Company.

Turco $4306-8$ is a trademerk of Turco Products, Incorporated. 


\subsection{SUMMARY OF CONCEPTUAL MODEL}

Based on the data available, a conceptual model of potential impacts of effluent discharges to the S-26 Crib is summarized below and illustrated in Figure 29.

- Wastewater discharged to the S-26 Crib moves through the crib sediments and into the Hanford formation. Lateral spreading occurs along discontinuous layers of fine-grained sediments as the water moves vertically through the soil column. The water table is within or just above the Plio-Pleistocene in this part of the 200 West Area.

- Discharges of 222-S Complex effluent containing low-level radioactive liquids and various 1 ab chemicals contributed to the soil column inventory. Laboratory sorption studies on Hanford Site soils treated with various detergents and decontamination chemicals (Knoll 1957) have shown enhanced radionuclide mobility. The detergents and decontamination chemicals used at the 222-S Complex would have been very dilute when discharged to the crib, so their effect on the soil column would be slight.

- Discharge of trucked-in PFP Complex caustic rinsate solution very likely formed chemical precipitates in the crib soil column and decreased the porosity and infiltration capacity of the crib.

- Small amounts of long-1ived radionuclides from the 222-S Laboratory Complex were released to the $\$-26 \mathrm{Crib}$ and are assumed to be present and retained on the crib sediments and soil column immediately beneath the crib.

- Aluminum and strontium-90 discharged to the S-26 Crib would most likely have moved further down in the soil column, but would not have broken through to groundwater. Groundwater chemistry results do not show any concentration above background values for these constituents.

- A potential preferential pathway exists along the unsealed portion of the well casing (299-W27-1), from $150 \mathrm{ft}(46 \mathrm{~m})$ to the water table. Contaminants could migrate down this pathway to the aquifer.

- Nitrate, sulfate, chloride, total uranium, tritium, gross alpha and beta, and several related metals (vanadium, strontium, and potentially selenium) occur in concentrations above background in the groundwater upgradient and beneath the S-26 Crib. These constituents are present because of past-practice disposal activities in the immediate area and are moving into the S-26 Crib area from upgradient sources.

The impact assessment presented in the following section addresses these issues using a combination of contaminant migration modeling, groundwater sampling and analysis results, and existing groundwater hydraulic data from other ongoing programs. 


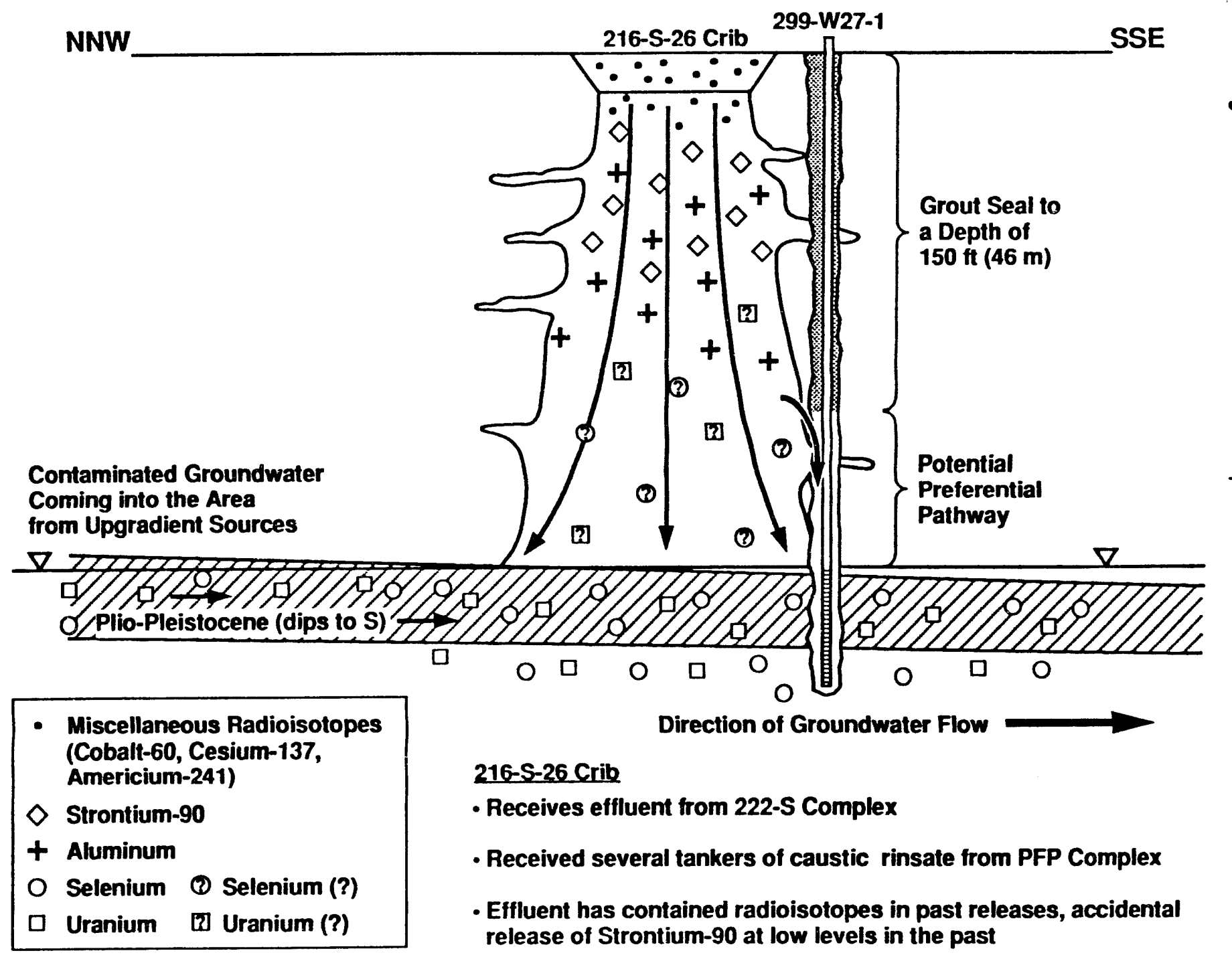

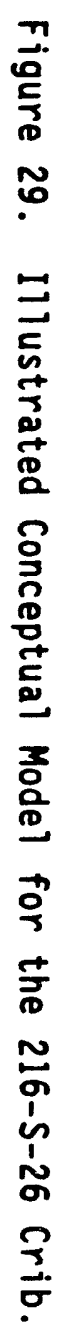


WHC-EP-0690

This page intentionally left blank. 


\subsection{IMPACT ASSESSMENT}

As required by the methodology document (Tyler 1991), both hydrologic and contaminant impacts are considered for each groundwater impact assessment. Accordingly, hydrologic factors relevant to the current status of the disposal facility are discussed first followed by contaminant transport analysis.

\subsection{HYDROLOGIC IMPACTS}

Based on current (and historical) discharges to the S-26 Crib, impact to the local groundwater flow regime is minimal. Groundwater flow is to the east-southeast in the vicinity of the S-26 Crib. There are no irregularities in the water table near the S-26 Crib. Discharged wastewater at the S-26 Crib is decreasing with time and will cease by June 1995.

Effluent discharged to the crib percolates downward through a multilayered sequence of sediments. Perched water conditions may occur within and upon the variance fine-grained sediment layers present beneath the crib. Lateral spreading of perched water is likely limited by discontinuities or pinchouts which are common to local sediments, or by features such as clastic dikes. The presence or extent of perched water associated with the S-26 Crib is unknown. The spreading of water in the vadose zone decreases the potential for measurable mounding at the water table.

\subsection{CONTAMINANT IMPACTS}

\subsubsection{Analytical Technique}

The one-dimensional analytical method described in the Liquid Effluent Study Final Project Report (WHC 1990a) estimates the rate of moisture and contaminant movement through the soil column beneath the $\mathrm{S}-26 \mathrm{Crib}$. The method considered only flow in the vertical direction and did not allow for lateral spreading. Thus, calculated contaminant migration rates are considered more conservative (faster) than actual contaminant migration rates.

The method used is based on steady-state flow conditions in the unsaturated zone and assumes a unit hydraulic gradient. The basic equation for any layer of sediments is

$$
t=L \times \theta / q
$$

where:

$t=$ time of travel through layer, seconds

$L=$ thickness of layer, centimeters

$\theta=$ moisture content of sediment, related to hydraulic conductivity

$q=$ Darcy velocity or moisture flux in layer, centimeter/second. 
The total travel time, $T$, is determined as the summation of the travel times for each of the " $i$ " layers:

$$
\prod_{i=1}^{n}=\sum L_{i} \times \theta_{i} / q_{i}
$$

where $n$ is the number of sediment layers. For transport calculation purposes, the soil column beneath the crib was treated as a two-layer system of $60 \mathrm{~m}$ (197 ft) depth. Figure 30 illustrates the soil column used in the original analytical solution.

The relationship between hydraulic conductivity, $K$, and moisture content, $\theta$, is described graphically in Figure 31. These curves were derived empirically from laboratory tests on more than 20 different Hanford Site sediment types and established five major sediment types, as noted in the figure.

The one-dimensional flow analys is embodied in equation 2 was carried out on a Symphony spreadsheet. The total travel time, $T$, obtained with equation 2 is divided into the vadose zone thickness to provide an estimate of the rate of moisture migration from the disposal facility to the groundwater.

To obtain an estimate of the rate of contaminant migration, the retardation factor, $R_{f}$, for each of the contaminants identified was estimated from the following approximation for Hanford soils:

$$
R_{f}=1+5 K_{d}
$$

Conservative $K_{d}$ values (i.e. at the lower end of observed ranges) were selected from the Ames and Serne (1991) tabulation for effluent described as "low salt, low organic, and neutral pH." When the rate of moisture migration is divided by the $R_{f}$ for the contaminant of interest, the result is an estimate of the contaminant migration rate. These computations were also carried out using the Symphony spreadsheet method.

Recent work has been done on Hanford Site sediments to update the $K_{d}$ values and "calibrate" these ranges. However, at the time of this document, the results are not yet available for use.

The effluent discharge rate, as described previously, was entered as liters per month in the spreadsheet computational method. Effluent volumes through 1987 listed in the Waste Stream Characterization Report (WHC 1989), were updated to include 1988 and 1989 data for the Liquid Effluent Study (WHC 1990a; the same average infiltration rate was also assumed for the time period subsequent to 1989). The total volume (liters) was divided by the

${ }^{1}$ Symphony is a registered trademark of the Lotus Development Corporation. 


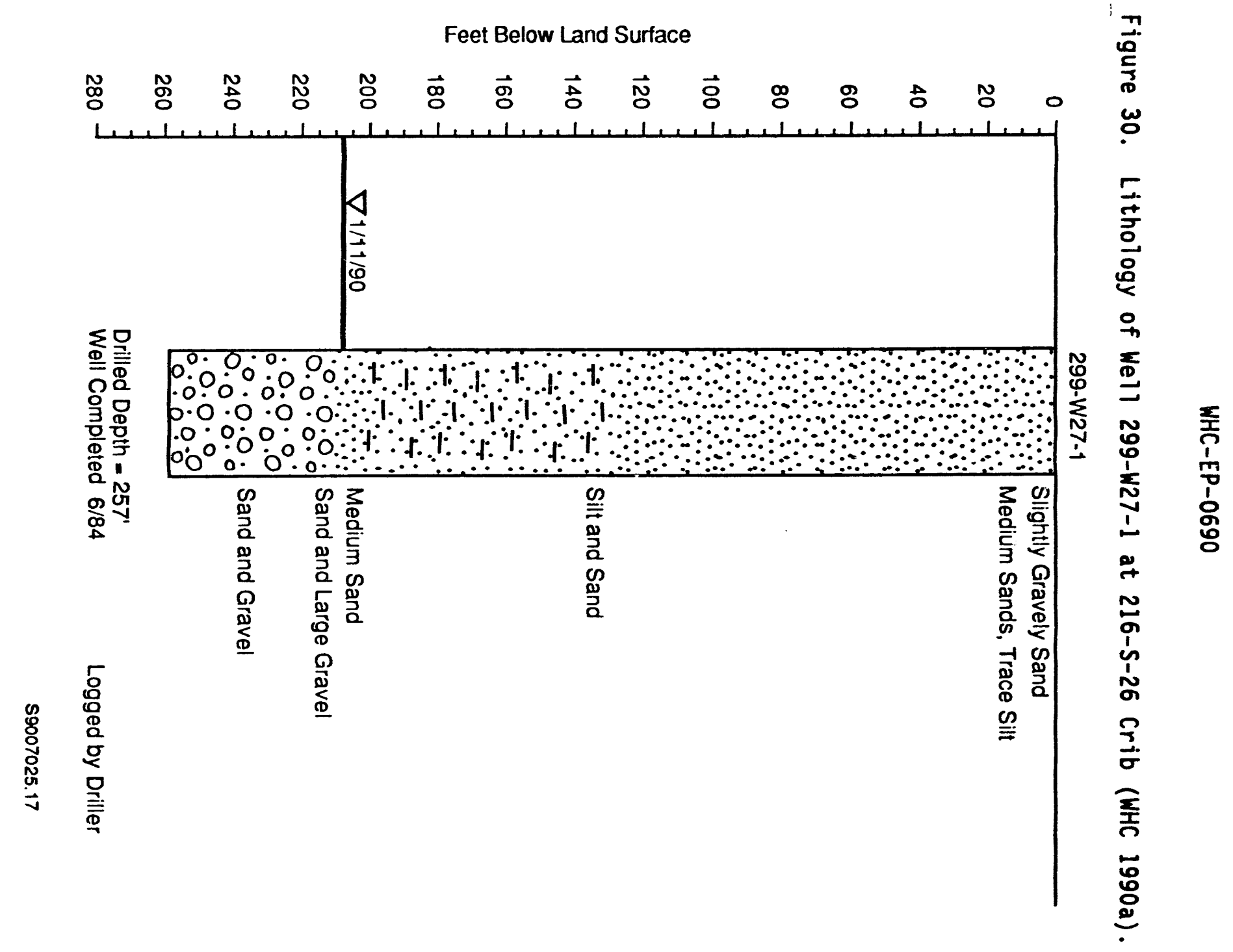


Figure 31. Hydraulic Conductivity Versus Moisture Content (WHC 1990a).

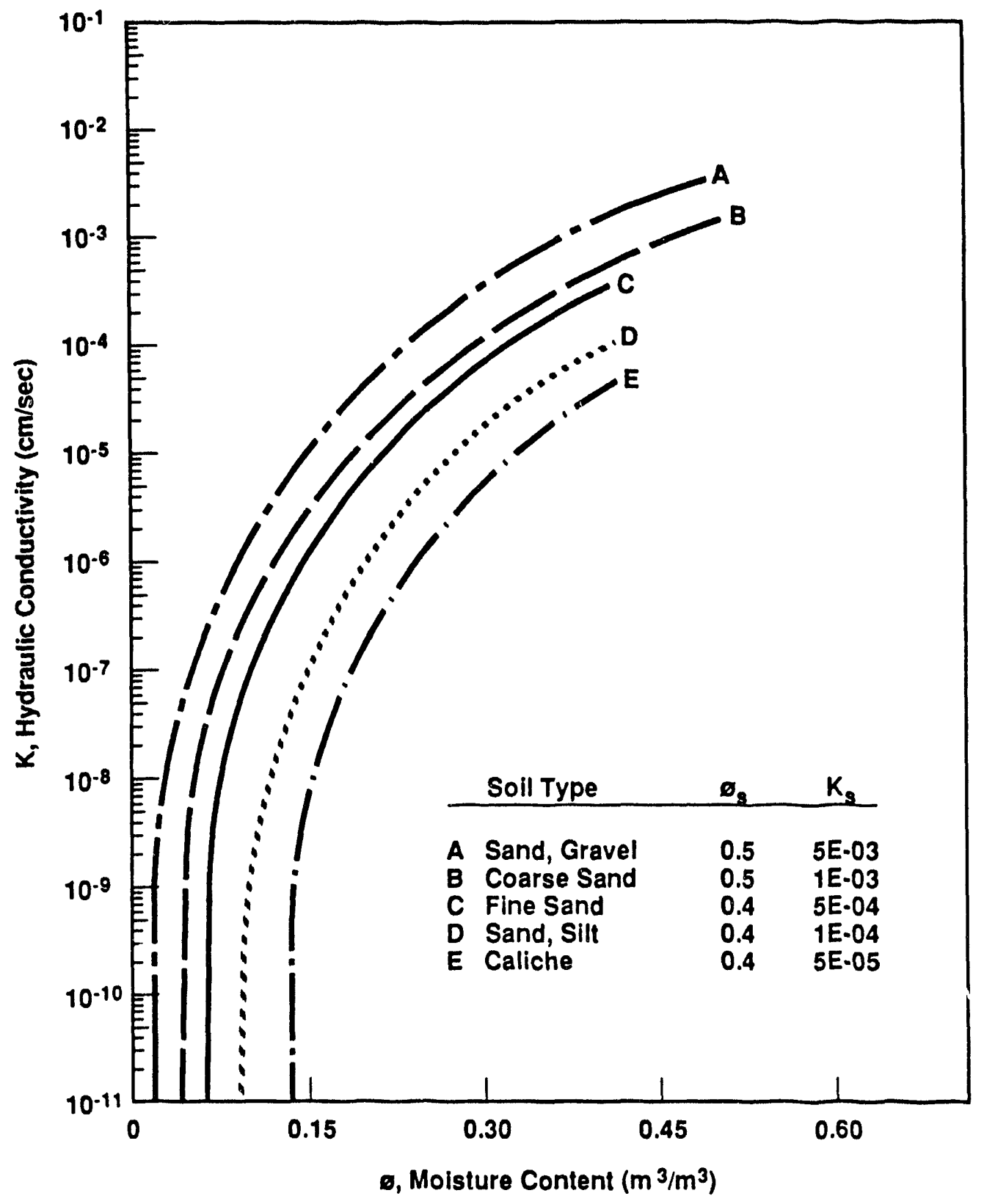

H9309026.5 
corresponding operating period (months) to establish an average rate of inflow (L/month). This effluent discharge rate was divided by the crib area to obtain an estimate of the average infiltration rate.

More details and an illustrative example for application of the overall computational approach are provided in the Liquid Effluent Study Final Project Report (WHC 1990a).

\subsubsection{Results of Initial Analytical Solution}

The following discussion summarizes the results from the Liquid Effluent Study Final Project Report (WHC 1990a), with the exception of selenium which was added for the purpose of this report.

Based on general effluent characteristics and corresponding sorption parameters (Section 5.2.1) for the key constituents identified in Table 15 plus new data for selenium, the calculated migration rates in the vadose zone (Table 16), listed most mobile to least mobile, are as follows:

- $36 \mathrm{~cm} /$ day (14 in/day) for selenium

- $3.6 \mathrm{~cm} /$ day (1.4 in/day) for uranium

- $0.4 \mathrm{~cm} /$ day $(0.16 \mathrm{in} / \mathrm{day})$ for 8 ? uminum

- $0.3 \mathrm{~cm} /$ day (0.12 in/day) for strontium-90

- $0.1 \mathrm{~cm} / \mathrm{day}(0.04 \mathrm{in} / \mathrm{day})$ for manganese-54, cobalt-60, and cesium-137

- $0.04 \mathrm{~cm} /$ day $(0.02 \mathrm{in} /$ day) for americium-241.

The most significant radiological constituents based on inventory, halflife and relative hazard potential are uranium, strontium-90, cobalt-60, and cesium-137. Based on the estimated migration rates for these constituents (Table 16) and above, breakthrough of uranium would have occurred after five years. The most significant nonradiological constituent is selenium and the analytical solution predicts breakthrough of selenium in half a year. The remaining constituents listed above would still be retained on the soil column, based on the analytical solution results.

\subsubsection{Actual Field Conditions and Indications}

Constituents present in the groundwater adjacent to and beneath the S-26 Crib site appear to be moving in from other disposal sites in the area (see Section 4.3). The concentrations of effluent constituents are lower than most groundwater constituent concentrations for the unconfined aquifer (Hanford Site average background values, Johnson 1993b). In addition, the effluent constituents are lower in concentration than most of the groundwater values from the well adjacent to the crib (299-W27-1). Based on present effluent characteristics and groundwater data, there is no evidence of the S-26 Crib effluent adversely affecting groundwater quality, and potential future impacts are not likely under these conditions. 
Table 15. Effluent Stream Sampling Data for the 216-S-26 Crib - Key Constituents (WHC 1990a).

\begin{tabular}{|c|c|c|c|c|c|c|}
\hline $\begin{array}{c}\text { Key } \\
\text { const ituents }\end{array}$ & Detection limit & $\begin{array}{l}\text { Detection/ } \\
\text { analyses }\end{array}$ & $\begin{array}{c}\text { Sample } \\
\text { concentratjon } \\
(90 x \mathrm{Cl})^{-6}\end{array}$ & Detection limit ${ }^{a}$ & $\begin{array}{l}\text { Detection } \\
\text { analyses }\end{array}$ & $\begin{array}{l}\text { Semple } \\
\text { concentratjon } \\
\text { (90\% C1) }\end{array}$ \\
\hline \multicolumn{4}{|c|}{$09 / 85$ to $04 / 89$, During rout ine operation } & \multicolumn{3}{|c|}{$10 / 89$ to $03 / 90$, During rout ine operation } \\
\hline Aluminum & Ma & $2 / 17$ & 330 & MA & No & MD \\
\hline \multicolumn{4}{|c|}{1976 to 1988 , During rout ine operation ${ }^{b}$} & \multicolumn{3}{|c|}{$10 / 89$ to $03 / 90$, During rout ine operation } \\
\hline Americium-241 & 40 & 1/NA & 63 & Ma & $4 / 4$ & 2 \\
\hline Cobalt -60 & MA & 1/NA & 280 & 1 & ND & ND \\
\hline Cesium-137 & 80 & 18/MA & 360 & 1 & NO & ND \\
\hline Mengenese-54 & Ma & 1/NA & 1.900 & Ma & ND & ND \\
\hline Stront ium-90 & 30 & 17/NA & 82 & 0.1 & $1 / 4$ & $0.2^{d}$ \\
\hline$\underset{\text { (isotopes) }}{\text { Uronium }}$ & MA & 4/MA & 670 & MA & $4 / 4$ & $0.267^{d, e}$ \\
\hline
\end{tabular}

Units: Chemical = Parts per billion (ppb).

Radionuclides $=$ i

bisposal of effluent to the 216-5-26 Crib began in 1984; thus, this data set includes some samples taken before 1984.

CUranium-234 Grow A study guidel ine used as the most restrictive for determination of key constituents.

Concentrations below Group A study guidel ines (HHC 1990b, Appendix A); values given for comperison purposes.

Consists of $0.14 \mathrm{pCi} / \mathrm{L}$ uranium-234 and $0.13 \mathrm{pCi} / \mathrm{L}$ uranium-238.

$\mathrm{CI}=$ Confidence interval.

ND $=$ Not detected. 
Table 16. Analytical Solution Results for the 216-S-25 Crib from the Liquid Effluent Study Final Project Report (WHC 1990a).

\begin{tabular}{|c|c|c|c|c|c|c|c|c|c|}
\hline $\begin{array}{l}\text { Disposal } \\
\text { facility }\end{array}$ & \multicolumn{2}{|c|}{$\begin{array}{c}\text { Rate } \\
\text { (L/month) }\end{array}$} & Area $\left(m^{2}\right)$ & \multicolumn{2}{|c|}{$\begin{array}{c}f \\
\text { (infiltration } \\
\text { rate } \mathrm{cm} / \mathrm{s} \text { ) }\end{array}$} & $\begin{array}{l}\text { Layer } \\
\text { number }\end{array}$ & \multicolumn{2}{|c|}{ Thickness (m) } & Soil type \\
\hline 216-S Crib & \multicolumn{2}{|c|}{$2.69 E+06$} & 390 & \multicolumn{2}{|c|}{$2.63 \mathrm{E}-04$} & $\begin{array}{l}1 \\
2\end{array}$ & \multicolumn{2}{|r|}{$\begin{array}{l}36 \\
24 \\
60\end{array}$} & $\begin{array}{l}\text { C } \\
\text { D }\end{array}$ \\
\hline$\theta_{8}$ & $k_{s}$ & $\boldsymbol{\theta}$ & $\begin{array}{l}\text { Moisture } \\
\text { state }\end{array}$ & \multicolumn{2}{|c|}{$\begin{array}{c}q \\
(\mathrm{~cm} / \mathrm{s})\end{array}$} & $\begin{array}{c}t \\
(s)\end{array}$ & $\begin{array}{c}T \\
\text { (d) }\end{array}$ & \multicolumn{2}{|c|}{$\begin{array}{l}\text { Estimated moisture } \\
\text { migration }(\mathrm{cm} / \mathrm{d})\end{array}$} \\
\hline $\begin{array}{l}0.4 \\
0.4\end{array}$ & $\begin{array}{l}5.0 \mathrm{E}-04 \\
1.0 \mathrm{E}-04\end{array}$ & $\begin{array}{l}0.36 \\
0.40\end{array}$ & $\begin{array}{l}\text { Unsaturated } \\
\text { Saturated }\end{array}$ & $\begin{array}{l}2.63 \\
1.00\end{array}$ & $\begin{array}{l}-04 \\
-04\end{array}$ & $\begin{array}{l}4.93 E+06 \\
9.60 E+06 \\
1.45 E+07\end{array}$ & 168 & & 35.7 \\
\hline \multicolumn{3}{|c|}{ Const ituent } & \multicolumn{2}{|c|}{$\stackrel{R_{f}}{\text { (retardation factor) }}$} & \multicolumn{3}{|c|}{$\begin{array}{l}\text { Estimated contaminant } \\
\text { migration }(\mathrm{cm} / \text { day })\end{array}$} & \multicolumn{2}{|c|}{$\begin{array}{l}\text { Contaminant transport } \\
\text { to water table (year) }\end{array}$} \\
\hline \multicolumn{2}{|c|}{$\begin{array}{c}\text { Aluminum } \\
\text { Manganese-54 } \\
\text { Uranium } \\
\text { Cobalt-60 } \\
\text { Stront ium-90 } \\
\text { Cesium-137 } \\
\text { Americium-241 } \\
\text { Selenium }\end{array}$} & & \multicolumn{2}{|l|}{$\begin{array}{r}100 \\
250 \\
10 \\
250 \\
125 \\
250 \\
1,000 \\
1^{8}\end{array}$} & \multicolumn{3}{|c|}{$\begin{array}{l}0.4 \\
0.1 \\
3.6 \\
0.1 \\
0.3 \\
0.1 \\
0.04 \\
36^{9}\end{array}$} & \multicolumn{2}{|c|}{$\begin{array}{r}46 \\
115 \\
5 \\
115 \\
58 \\
115 \\
461 \\
0.5^{\circ}\end{array}$} \\
\hline
\end{tabular}

"Selenium was not included in the original analytical solution run for the Liquid Effluent Study Final Project Report (WHC-EP-0367); it has been added to this table because current groundwater data suggest it is also a constituent of interest to this report. 


\subsection{EVALUATION OF MONITORING NETWORK ADEQUACY}

\subsubsection{Groundwater Monitoring Well Placement}

The closest well upgradient (299-W22-21) is approximately $503 \mathrm{~m}$ $(1,650 \mathrm{ft})$ to the northwest. One well is due north $(299-w 22-20)$ of the crib about $122 \mathrm{~m}(400 \mathrm{ft})$ away, but is not truly upgradient. The nearest well downgradient of the crib (other than 299-W27-1 which is located at the crib) is approximately $550 \mathrm{~m}(1,800 \mathrm{ft})$ to the southeast (699-32-72). If discharge continues beyond the cessation date, then installation of an upgradient monitoring well and possibly an additional downgradient monitoring well should be considered. This would clearly distinguish upgradient groundwater contamination from the influence of the $S-26$ Crib. Based on current effluent chemistry and discharge volumes to the crib, and groundwater chemical and radiological constituent concentrations, the existing groundwater monitoring well should be adequate for monitoring the crib until the June 1995 cessation date for discharge.

\subsubsection{Reporting of Monitoring Data}

A1l hydrochemical monitoring data are reported in the HEIS database, which is publicly accessible. Monitoring results for the wells in S-26 Crib area, for all historical data through July 1993 for well 299-W27-1 and data from 1896 through July 1993 for other wells, were summarized and used to evaluate the groundwater quality and chemistry in Section 4.3 in the previous section (see Appendices $A-1$ and $A-2$ ). 


\subsection{SUMMARY AND CONCLUSIONS}

\subsection{GROUNDWATER QUALITY IMPACTS}

Effluent data, vadose zone transport predictions, and groundwater chemistry data suggest the S-26 Crib has minimal influence on groundwater contamination in the southern 200 West Area. Locally the primary groundwater contaminants are uranium, nitrate, tritium, and chloroform, which are attributed to other past-practice disposal sites in the vicinity of the S-26 Crib. The most likely sources are the 216-S-1, 216-S-2, 216-S-7, 216-S-9, 216-S-13, and 216-S-25 Cribs, which are located to the northwest of the S-26 Crib. Other potential sources are the 216-S-22 Crib and 216-S-12 Trench, located to the north of the S-26 Crib.

Calculated transport times for constituents of interest (manganese-54, cobalt-60, cesium-137, americium-241, strontium-90, and aluminum) to the water table were all more than 40 years (WHC 1990a). Therefore, any of these constituents present in the crib are still retained in the soil column. Calculated transport times for uranium and selenium were less than five years. However, there is no conclusive evidence that the uranium and selenium present in the groundwater at the $S-26 \mathrm{Crib}$ are due to discharges to the crib. Based on comparison between the S-26 Crib effluent and upgradient groundwater contaminant levels, it is likely that the source of these constituents is upgradient of the S-26 Crib. The most likely sources are the 216-S-1, 216-S-2, 216-S-7, 216-S-13, and 216-S-25 Cribs.

\subsection{HYDROLOGIC IMPACTS}

Discharge of water to the S-26 Crib, under current conditions (September 1993), does not substantially impact artificial recharge to the southern 200 West Area unconfined aquifer.

\subsection{CONCLUSIONS}

Continued short-term operation of the S-26 Crib will have little effect on groundwater contamination in the southern 200 West Area. The groundwater monitoring well currently installed at the S-26 Crib is adequate for use of the crib, under current operating conditions (September 1993), until the June 1995 cessation date. If discharges to the S-26 Crib continue beyond June 1995, it would be advisable to install additional groundwater monitoring wells for this site, to provide better up and downgradient monitoring capabilities. 
This page intentionally left blank. 


\subsection{REFERENCES}

Ames, L. L., and R. J. Serne, 1991, Compilation of Data to Estimate Groundwater Migration Potential for Constituents in Active Liquid Discharges at the Hanford Site, PNL-7660, Pacific Northwest Laboratory, Richland, Washington.

Baker, V. R., B. N. Bjornstad, A. J. Busacca, K. R. Fecht, E. P. Kiver, U. L. Moody, J. G. Rigby, D. F. Stradling, and A. M. Tallman, 1991, "Quaternary Geology of the Columbia Plateau," in Quaternary Nonglacial Geology, Conterminous United States, R. B. Morrison (ed.), Geological Society of America, The Geology of North America, vol. K-2, Boulder, Colorado, Pp. 215-250.

Bjornstad, B. N., 1984, Suprabasalt Stratigraphy Within and Adjacent to the Reference Repository Location, SD-BWI-DP-039, Rockwell Hanford Operations, Richland, Washington.

Black, R. F., 1979, Clastic Dikes of the Pasco Basin, Southeastern Washington, RHO-BWI-C-64, Rockwell Hanford Operations, Richland, Washington.

Campbe11, N. P., 1989, "Structural and Stratigraphic Interpretation of Rocks Under the Yakima Fold Belt, Columbia Basin, Based on Recent Surface Mapping and Well Data," in Volcanism and Tectonism in the Columbia FloodBasalt Province, Special Paper 239, S. P. Reidel and P. R. Hooper (eds.), Geological Society of America, Boulder, Colorado, pp. 209-222.

Comprehensive Environmental Response, Compensation, and Liability Act of 1980, 42 USC 9601 , et seq.

Connelly, M. P., K. A. Lindsey, J. V. Borghese, and B. H. Ford, 1992, Hydrogeologic Model for the 200 West Groundwater Aggregate Area, WHC-SD-EN-TI-014, Westinghouse Hanford Company, Richland, Washington.

Coony, F. M., and S. P. Thomas, 1989, Westinghouse Hanford Company Effluent Discharges and Solid Waste Management Report for Calendar Year 1988: 200/600 Areas, WHC-EP-0141-1, Westinghouse Hanford Company, Richland, Washington.

Delaney, C. D., K. A. Lindsey, and S. P. Reidel, 1991, Geology and Hydrology of the Hanford Site: A Standardized Text for Use in Westinghouse Hanford Company Documents and Reports, WHC-SD-ER-TI-003, Rev. 0, Westinghouse Hanford Company, Richland, Washington.

DOE, 1988, Site Characterization Plan, Reference Repository Location, Hanford Site, Washington, Consultation Draft, DOE/RW-0164, U.S. Department of Energy, Washington, D.C.

DOE-RL, 1992, S-Plant Aggregate Area Management Study Report, DOE/RL-91-60, U.S. Department of Energy, Richland, Washington. 
Ecology, EPA, DOE-RL, 1991, Hanford Federal Facility Agreement and Consent Order, Second amendment, Two volumes, 89-10 Rev. 2, Washington Department of Ecology, 0lympia, Washington, U.S. Environmental Protection Agency, Region X, Seattle, Washington, and U.S. Department of Energy, Richland Operations Office, Richland, Washington.

Fecht, K. R., S. P. Reidel, and A. M. Tallman, 1987, Paleodrainage of the Columbia River System on the Columbia Platea: nf Washington State -A Summary, in Selected Papers on the Geology or Washington, Division of Geology and Earth Resources, J. E. Schuster (ed.), Bulletin 77, pp. 219-248.

Ford, B. H., 1993, Groundwater Field Characterization Report for the 200 Aggregate Area Management Study, WHC-SD-EN-TI-020, Westinghouse Hanford Company, Richland, Washington.

Gee, G. W., 1987, Recharge of the Hanford Site: Status Report, PNL-6403, Pacific Northwest Laboratory, Richland, Washington.

Graham, M. J., M. D. Hal1, S. R. Strait, and W. R. Brown, 1981, Hydrology of the Separations Area, RHO-ST-42, Rockwell Hanford Operations, Richland, Washington.

Graham, M. J., G. V. Last, and K. R. Fecht, 1984, An Assessment of Aquifer Intercommunication in the $B$ Pond-Gable Mountain Pond Area of the Hanford site, RHO-RE-ST-12, Rockwell Hanford Operations, Richland, Washington.

Ha11, M. J., 1990, 222-S Laboratory Wastewater Stream-Specific Report, WHC-EP-0342, Westinghouse Hanford Company, Richland, Washington.

Johnson, V. G., 1993a, Groundwater Impact Assessment Report for the 216-Z-20 Crib, 200 West Area, WHC-EP-0674, Westinghouse Hanford Company, Richland, Washington.

Johnson, V. G., 1993b, Westinghouse Hanford Company Operational Groundwater Status Report, WHC-EP-0595, Westinghouse Hanford Company, Richland, Washington.

Jones, T. E. (session chair), 1993, Hanford Technical Exchange Program Process Chemistry at Hanford (Genesis of Hanford Wastes), PNL-SA-23121 S, Pacific Northwest Laboratory, Richland, Washington.

Kasza, G. L., M. J. Hartman, F. N. Hodges, and D. C. Weekes, 1992, Groundwater Maps of the Hanford Site, June 1992, WHC-EP-0394-5, Westinghouse Hanford Company, Richland, Washington.

Klem, M. J., 1990, Inventory of Chemicals Used at Hanford Site Production Plants and Support Operations (1944-1980), WHC-EP-0172, Westinghouse Hanford Company, Richland, Washington.

Knol1, K. C., 1957, Effects of Detergents Upon Absorption of Radioisotopes by Soi7s, HW-52055, General Electric Company, Hanford Atomic Products Operation, Richland, Washington. 
Last, G. V., B. N. Bjornstad, M. P. Bergeron, R. W. Wallace, D. R. Newcomer, J. A. Schramke, M. A. Chamness, C. S. Ciine, S. P. Airhart, and J. S. Wilbur, 1989, Hydrogeology of the 200 Areas Low-Level Burial Grounds -- An Interim Report, PNL-6820, Pacific Northwest Laboratory, Richland, Washington.

Lindsey, K. A., 1991a, Revised Stratigraphy for the Ringold Formation, Hanford Site, South-Central Washington, WHC-SD-EN-EE-004, Rev. 0, Westinghouse Hanford Company, Richland, Washington.

Lindsey, K. A., 1991b, Sedimentation and Basin Evolution of the Late Neogene Ringold Formation, Central Columbia Plateau, South-Central Washington, Geological Society of America Abstracts with Programs, Boulder, Colorado, Vol. 23, No. 5, p. A285.

Lindsey, K. A., 1992, Geology of the Northern Part of the Hanford Site: An Outline of Data Sources and the Geologic Setting of the 100 Areas, WHC-SD-EN-TI-011, Westinghouse Hanford Company, Richland, Washington.

Lindsey, K. A., M. P. Connelly, and B. N. Bjornstad, 1991, Geologic Setting of the 200 West Area: An Update, WHC-SD-EN-TI-008, Westinghouse Hanford Company, Richland, Washington.

Myers, C. W., S. M. Price, J. A. Caggiano, M. P. Cochran, W. J. Czimer, N. J. Davidson, R. C. Edwards, K. R. Fecht, G. E. Holmes, M. G. Jones, J. R. Kunk, R. D. Landon, R. K. Ledgerwood, J. T. Lillie, P. E. Long, T. H. Mitchell, E. H. Price, S. P. Reidel, and A. M. Tallman, 1979, Geologic Studies of the Columbia Plateau: A Status Report, RHO-BWI-ST-4, Rockwell Hanford Operations, Richland, Washington.

PSPL, 1982, Skagit/Hanford Nuclear Project, Preliminary Safety Analysis Report, Vo1. 4, App. 20, Amendment 23, Puget Sound Power and Light Company, Bellevue, Washington.

Reidel, S. P., 1984, "The Saddle Mountains: The Evolution of an Anticline in the Yakima Belt," American Journal of Science, Vol. 284, pp. 942-978.

Reidel, S. P., and K. R. Fecht, 1981, "Wanapum and Saddle Mountains Basalt in the Cold Creek Syncline Area," in Subsurface Geology of the Cold Creek Syncline, RHO-BWI-ST-14, Rockwell Hanford Operations, Richland, Washington.

Reidel, S. P., and P. R. Hooper (eds.), 1989, Volcanism and Tectonism in the Columbia River Flood-Basalt Province, Special Paper 239, Geological Society of America, Boulder, Colorado, p. 386.

Reidel, S. P., K. R. Fecht, M. C. Hagood, and T. L. Tolan, 1989, "The Geologic Evolution of the Central Columbia Plateau," in Volcanism and Tectonism in the Columbia River Flood-Basalt Province, Special Paper 239, S. P. Reidel and P. R. Hooper (eds.), Geological Society of America, Boulder, Colorado, Pp. 247-264. 
Reidel, S. P., K. A. Lindsey, and K. R. Fecht, 1992, Field Trip Guide to the Hanford Site, WHC-MR-0391, Westinghouse Hanford Company, Richland, Washington.

Rockhold, M. L., M. J. Fayer, G. W. Gee, and M. J. Kanyid, 1990, Natural Groundwater Recharge and Water Balance at the Hanford Site, PNL-7215, Pacific Northwest Laboratory, Richland, Washington.

Routson, R. C., and V. G. Johnson, 1990, "Recharge Estimates for the Hanford Site 200 Areas Plateau," Northwest Science, Vol. 64, No. 3.

Smith, G. A., 1988, Neogene Synvolcanic and Syntectonic Sedimentation in Central Washington, Geological Society of America Bulletin, Boulder, Colorado, Vol. 100, pp. 1479-1492.

Smith, G. A., B. N. Bjornstad, and K. R. Fecht, 1989, "Neogene Terrestrial Sedimentation on and Adjacent to the Columbia Plateau; Washington, Oregon, and Idaho," in Volcanism and Tectonism in the Columbia River Flood-Basalt Province, Special Paper 239, S. P. Reidel and P. R. Hooper (eds.), Geological Society of America, Boulder, Colorado, pp. 187-198.

Stordeur, R. T., and D. L. Flyckt, 1988, Annual Status Report of the Plan and Schedule to Discontinue Disposal of Contaminated Liquids into the Soil Column at the Hanford Site, WHC-EP-0196-1, Westinghouse Hanford Company, Richland, Washington.

Tallman, A. M., K. R. Fecht, M. C. Marratt, and G. V. Last, 1979, Geology of the Separations Areas, Hanford Site, South-Central Washington, RHO-ST-23, Rockwell Hanford Operations, Richland, Washington.

Tallman, A. M., J. T. Lillie, and K. R. Fecht, 1981, "Suprabasalt Sediments of the Cold Creek Syncline Area," in Subsurface Geology of the Cold Creek Syncline, RHO-BWI-ST-14, C.W. Myers and S. M. Price (eds.), Rockwell Hanford Operations, Richland, Washington.

Tolan, T. L., and S. P. Reidel, 1989, "Structure Map of a Portion of the Columbia River Flood-Basait Province," in Volcanism and Tectonism in the Columbia River Flood-Basalt Province, Special Paper 239, S. P. Reidel and P. R. Hooper (eds.), Geological Society of America, Boulder, Colorado, Plate 1.

Tolan, T. L., S. P. Reidel, M. H. Beeson, J. L. Anderson, K. R. Fecht, and D. A. Swanson, 1989, "Revisions to the Extent and Volume of the Columbia River Basalt Group," in Volcanism and Tectonism in the Columbia River Flood-Basalt Province, Special Paper 239, S. P. Reidel and P. R. Hooper (eds.), Geological Society of America, Boulder, Colorado, pp. 1-20.

Tyler, D. K., 1991, A Methodology for Assessing Impacts to Groundwater from Disposal of Liquid Effluent to the Soil at the Hanford Site, WHC-SD-EN-EV-008, Rev. 0, Westinghouse Hanford Company, Richland, Washington.

WAC 173-200, 1990, "Water Quality Standards of the State of Washington," Washington Administrative Code, as amended. 
WAC 173-303, 1990, "Dangerous Waste Regulations," Washington Administrative Code, as amended.

Warwick, G. J., 1992, 222-S Laboratory Wastewater to 216-S-26 Crib Sampling and Analysis Plan, WHC-SD-WM-EV-075, Westinghouse Hanford Company, Richland, Washington.

WHC, 1988, Environmental Compliance, WHC-CM-7-5, Westinghouse Hanford Company, Richland, Washington.

WHC, 1989, Waste Stream Characterization Report, WHC-EP-0287, Vo1. 3, Westinghouse Hanford Company, Richland, Washington.

WHC, 1990a, 222-S Laboratory Wastewater Stream-Specific Report, WHC-EP-0342, Addendum 13, Westinghouse Hanford Company, Richland, Washington.

WHC, 1990b, Liquid Effluent Study Final Project Report, WHC-EP-0367, Westinghouse Hanford Company, Richland, Washington.

WHC, 1990c, Liquid Effluent Study: Groundwater Characterization Data, WHC-EP-0366, Westinghouse Hanford Company, Richland, Washington.

WHC, 1991, Waste Information Data System (WIDS), Westinghouse Hanford Company, Richland, Washington. 


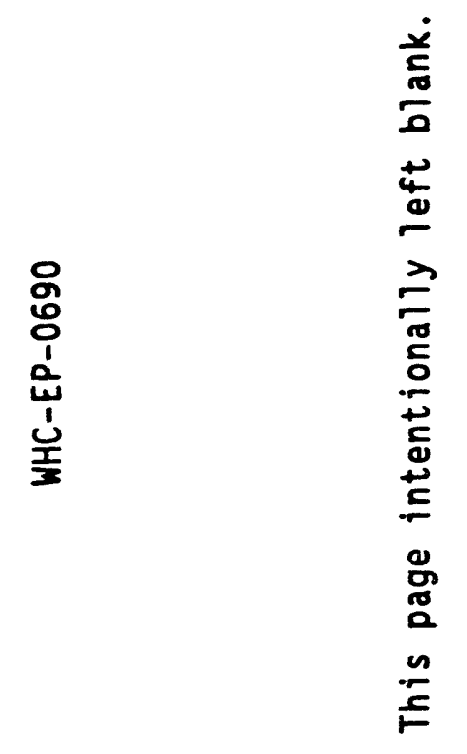


WHC-EP-0690

\section{APPENDIX $A-1$}

GROUNDWATER DATA FOR WELL 299-W27-1

(MONITORING WELL FOR 216-S-26 CRIB) 
WHC-EP-0690

This page intentionally left blank. 
Analytical results monitoring well 299-W27-1 are listed by constituent name and sampling date on pages Al-2 through Al-71. Results are reported in the Hanford Environmental Information System (HEIS) database, which was queried for results in July of 1993. The time period covered by these results starts just after the well was installed in 1984 and goes through July of 1993.

\section{Qualifiers}

Qualifiers concerning the data are indicated with a letter code in the seventh column and are defined as follows:

B - Blank assoiated with analyte is elevated in concentration

D. - Sample was diluted before analysis

E - Concentration is out of instrument calibration range

$J$ - Concentration is estimated

$U$ - Analyte concentration is below contract required quantification limit

$H$ - Laboratory holding time exceeded

$R$ - Suspect data; currently under review

Q - Result associated with suspect quality control data

P - Potential problem.

It should also be noted that not all of the data in the table were reviewed at the time this report was prepared. Thus, some unflagged "suspect" data may exist in the table.

\section{Significant Figures}

No more than three significant figures are justified; any additional places are database format related.

\section{Natural Background Reference Levels}

A summary of provisional background concentrations for naturally occuring constituents is provided on pages Al-72 through Al-74. Monitoring results listed on pages Al-2 through Al-71 can be compared with either the average natural background concentrations or with the provisional threshold values (columns 4 and 5 , respectively, pages Al-72 through A1-74). The latter represent the upper range of naturally occuring concentrations that are considered likely to occur at the Hanford Site based on currently available data. A major sampling effort is underway to better define both soil and groundwater natural background for the Hanford Site. 
Well Constituent Name

\section{9-W27-1}

299-W27-1

299-W27-1

299-W27-1

299-W27-1

299-W27-1

299-W27-1

299-W27-1

299-W27-1

299-W27-1

299-W27-1

? 299-W27-1

$\sim 299-W 27-1$

299-W27-1

299-W27-1

299-W27-1

299-W27-1

299-W27-1

299-W27-1

299-W27-1

299-W27-1

299-W27-1

299-W27-1

299-W27-1

299-W27-1

299-W27-1

299-W27-1

299-W27-1
1.1.1.2-Tetrachloroethane

1.1.1.2-Tetrachloroethane

1.1.1.2-Tetrachloroethane

1.1.1.2-Tetrachloroethane

1.1.1.2-Tetrachloroethane

1.1.1-Trichloroethane

1.1.1-Trichloroethane

1.1.1-Trichloroethane

1.1.1-Trichloroethane

1.1.1-Trichloroethane

1.1.1-Trichloroethane

1.1.1-Trichloroethane

1.1.1-Trichloroethane

1.1.1-Trichloroethane

1.1.1-Trichloroethane

1.1.1-Trichloroethane

1.1.1-Trichloroethane

1.1.1-Trichloroethane

1.1.1-Trichloroethane

1.1.1-Trichloroethane

1.1.2.2-Tetrachloroethane

1.1.2.2-Tetrachloroethane

1.1.2.2-Tetrachloroethane

1.1.2.2-Tetrachloroethane

1.1.2.2-Tetrachloroethane

1.1.2-Trichloroethane

1.1.2-Trichloroethane

1.1.2-Trichloroethane
Collect Date Result Error Filtered Qualifier Units

$7 / 24 / 87 \quad 10$

$7 / 24 / 87$

$10 / 15 / 87$

$1 / 15 / 88$

$8 / 18 / 88$

$1 / 11 / 90$

3/09/87

$4 / 17 / 87$

$7 / 24 / 87$

$10 / 15 / 87$

$1 / 15 / 88$

$8 / 18 / 88$

$12 / 12 / 88$

$1 / 11 / 90$

$4 / 12 / 90$

$2 / 03 / 92$

$3 / 23 / 92$

$7 / 01 / 92$

$10 / 27 / 92$

$12 / 29 / 92$

$4 / 12 / 93$

$7 / 24 / 87$

$10 / 15 / 87$

$1 / 15 / 88$

$8 / 18 / 88$

$1 / 11 / 90$

$3 / 09 / 87$

$4 / 17 / 87$

$7 / 24 / 87$

Error

-.....

Qualifier

.......

ppb

ppb

ppb

ppb

$\mathrm{ppb}$
$\mathrm{ppb}$

4

ppb

$\mathrm{ppb}$

ppb

$\mathrm{ppb}$

$\mathrm{ppb}$
$\mathrm{ppb}$

$\mathrm{ppb}$

ppb

$\mathrm{ppb}$

ppb

$\mathrm{ppb}$

$\mathrm{ppb}$

ppb

ppb

$\mathrm{ppb}$
$\mathrm{ppb}$

$\mathrm{ppb}$

ppb

$\mathrm{ppb}$

ppb

$\mathrm{ppb}$

ppb

ppb

ppb

$\mathrm{ppb}$
CRQL Method Name

5 SW-846 8240

5 SW-846 8240

5 SW-846 8240

5 SW-846 8240

5 SW-846 8240

5 SW-846 8240

5 SW- 8468240

5 SW- 8468240

5 SW- 8468240

5 SW-846 8240

5 SW-846 8240

5 SW-846 8240

5 SW-846 8240

5 SW-846 8240

5 SW-846 8240

5 SW- 8468240

5 SW-846 8240

5 SW-846 8240

5 SW-846 8240

5 SW-846 8240

5 SW- $846 \quad 8240$

5 SW-846 8240

5 SW-846 8240

5 SW-846 8240

5 SW-846 8240

$\begin{array}{lll}5 & \text { SW- } 846 \quad 8240\end{array}$

5 SW- 8468240

5 SW-846 8240 
Well

299.627 .1

299. $W 27 \cdot 1$

299. W27-1

299. W27-1

$299 \cdot \mathrm{W} 27 \cdot 1$

299-W27-1

$299 \cdot W 27-1$

299-W27-1

299.W27-1

299.W27-1

299. W27-1

299. W27-1

2 299-W27-1

'ं 299-W27-1

299-W27-1

299-W27-1

299-W27-1

299-W27-1

299-W27-1

299-W27-1

299-W27-1

299-W27-1

299- $-W 27-1$

299-W27-1

299-W27-1

290-W27-1

299-W27-1

299. $\$ 27-1$

299-W27-1

299-W27-1
Constituent Name

1. 1.2.Trichloroethane

1.1.2-Trichloroethane

1.1.2-ichloroethane

1.1.2-Trichlornethane

1.1.2-Trichloroethane

1.1.2-Trichloroethane

1.1.2.Trichlorcethane

1.1.2-Trichloroethane

1.1.2-Trichloroethane

1.1.2-Trichloroethane

1.1.2-Trichloroethane

1.1.2-Trichioroethane

1.1. Dichloroethane

1.1-Dichloroethane

1.1. Dichloroethane

1.1. Dichioroethane

1.1-Dichloroethane

1.1-Dichloroethane

1.1-Dichioroethane

1.1-Dichloroethane

1.1-Dichloroethane

1.1-Dichloroethane

1.1-Dichloroethane

1.1-Dichloroethane

1.1-Dichloroethene

1.1-Dichloroethene

1.1.Dichloroethene

1.1-Dichloroethene

1.1. Dichloroethene

1.1.Dichloroethene
Collect Date Perult Frror

$10 / 15 / 87$

$1 / 15 / 88$

$8 / 18 / 88$

$12 / 12 / 88$

$1 / 11 / 90$

$4 / 12 / 90$

$2 / 03 / 92$

$3 / 23 / 92$

$7 / 01 / 92$

$10 / 27 / 92$

$12 / 29 / 92$

$4 / 12 / 93$

$7 / 24 / 87$

$10 / 15 / 87$

$1 / 15 / 88$

$8 / 18 / 88$

$1 / 11 / 90$

$4 / 12 / 90$

$2 / 03 / 92$

$3 / 23 / 92$

$7 / 01 / 92$

$10 / 27 / 92$

$12 / 29 / 92$

$4 / 12 / 93$

$7 / 24 / 87$

$10 / 15 / 87$

$1 / 15 / 88$

$8 / 18 / 88$

$1 / 11 / 90$

$2 / 03 / 92$

10

10

10
10
10

10
5

5

5
5

5
5

5

5

5

5

5
10

10

10

10
10

10
10

Filtered Oualifier Units$$
\text { u }
$$$$
\text { U }
$$$$
\text { it }
$$$$
\text { U }
$$$$
2
$$

2$$
\text { u }
$$$$
\text { U }
$$$$
\text { U }
$$$$
\text { U }
$$$$
\text { u }
$$$$
\text { U }
$$

In

4

$\mathrm{ppb}$

ppb

$\begin{array}{llll}\mathrm{ppb} & 5 & \mathrm{SW}-846 & 8240 \\ \mathrm{ppb} & 5 & \mathrm{SW}-846 & 8240 \\ \mathrm{ppb} & 5 & \mathrm{SW}-846 & 8240 \\ \mathrm{ppb} & 5 & \mathrm{SW}-846 & 8240 \\ \mathrm{ppb} & 5 & \mathrm{SW}-846 & 8240 \\ \mathrm{ppb} & 5 & \mathrm{SW}-846 & 8240 \\ \mathrm{ppb} & 5 & \mathrm{SW}-846 & 8240 \\ \mathrm{ppb} & 5 & \mathrm{SW}-846 & 8240 \\ \mathrm{ppb} & 5 & \mathrm{SW}-846 & 8240 \\ \mathrm{ppb} & 5 & \mathrm{SW}-846 & 8240 \\ \mathrm{ppb} & 5 & \mathrm{SW}-846 & 8240 \\ \mathrm{ppb} & 5 & \mathrm{SW}-846 & 8240\end{array}$

5 SW-846 8240

5 SW-846 8240

5 SW-846 8240

5 SW-846 8240

5 SW-846 8240

5 SW-846 8240

5 SW-846 8240

5 SW-846 8240

5 SW- $846 \quad 8240$

5 SW-846 8240

5 SW-846 8240

$\mathrm{ppb}$
$\mathrm{ppb}$

5 SW-846 8240 


\begin{tabular}{|c|c|c|c|c|c|c|c|c|}
\hline Well & Constituent Name & Collect Date & Result & Error Filtered & Qualifier & Units & CRQL & Method Name \\
\hline $299 \cdot W 27 \cdot 1$ & 1.1-Dimethylhydrazine & $1 / 11 / 90$ & 10 & 4 & u & ppb & $\cdots \cdots$ & ........ \\
\hline 299-W27-1 & 1.2.3.4-tetrachlorobenzene & $7 / 24 / 87$ & 10 & & $u$ & $\mathrm{ppb}$ & & \\
\hline $299 \cdot W 27 \cdot 1$ & 1.2.3.4-tetrachlorobenzene & $10 / 15 / 87$ & 10 & & U & $\mathrm{ppb}$ & & \\
\hline $299 \cdot W 27 \cdot 1$ & 1.2.3.4-tetrachlorobenzene & $1 / 15 / 88$ & 10 & & U & $\mathrm{ppb}$ & & \\
\hline $299-W 27-1$ & 1.2.3.4-tetrachlorobenzene & $1 / 11 / 90$ & 10 & 4 & $u$ & $\mathrm{ppb}$ & & \\
\hline $299 \cdot W 27 \cdot 1$ & 1.2.3.5-tetrachlorobenzene & $7 / 24 / 87$ & 10 & & U & $\mathrm{ppb}$ & & SW-846 8270 \\
\hline $299 \cdot+27-1$ & 1.2.3.5-tetrachlorobenzene & $10 / 15 / 87$ & 10 & & U & $\mathrm{ppb}$ & & SW-846 8270 \\
\hline $299-W 27-1$ & 1.2.3.5-tetrachlorobenzene & $1 / 15 / 88$ & 10 & & U & fpb & & SW-846 8270 \\
\hline $299-W 27-1$ & 1.2.3.5-tetrachlorobenzene & $1 / 11 / 90$ & 10 & 4 & U & $\mathrm{ppb}$ & & SW-846 8270 \\
\hline $299 \cdot W 27-1$ & 1.2.3-Trichloropropane & $7 / 24 / 87$ & 10 & & $u$ & $\mathrm{ppb}$ & & \\
\hline $299-W 27 \cdot 1$ & 1.2.3-Trichloropropane & $7 / 24 / 87$ & 10 & & U & $\mathrm{ppb}$ & 5 & SW-846 8240 \\
\hline 2 299-W27-1 & 1.2.3-Trichloropropane & $10 / 15 / 87$ & 10 & & U & $\mathrm{ppb}$ & & \\
\hline$\quad 299-W 27-1$ & 1.2.3-Trichloropropane & $10 / 15 / 87$ & 10 & & U & $\mathrm{ppb}$ & 5 & SW-846 8240 \\
\hline 299-W27-1 & 1.2.3-Trichloropropane & $1 / 15 / 88$ & 10 & & U & $\mathrm{ppb}$ & & \\
\hline $299-W 27-1$ & 1.2.3-Trichloropropane & $1 / 15 / 88$ & 10 & & U & $\mathrm{ppb}$ & 5 & SW-846 8240 \\
\hline $299-W 27-1$ & 1.2.3-Trichloropropane & $8 / 18 / 88$ & 10 & & $u$ & $\mathrm{ppb}$ & & \\
\hline $299-W 27-1$ & 1.2.3-Trichloropropane & $8 / 18 / 88$ & 10 & & $\mathrm{U}$ & $\mathrm{ppb}$ & 5 & SW- 8468240 \\
\hline $299-W 27-1$ & 1.2.3-Trichloropropane & $1 / 11 / 90$ & 10 & 4 & ॥ & $\mathrm{ppb}$ & 5 & SW- 8468240 \\
\hline $299-W 27-1$ & 1.2.3-trichlorobenzene & $7 / 24 / 87$ & 10 & & U & $\mathrm{ppb}$ & & \\
\hline $299-W 27-1$ & 1.2.3-trichlorobenzene & $10 / 15 / 87$ & 10 & & U & $\mathrm{ppb}$ & & \\
\hline $299-W 27-1$ & 1.2.3-trichlorobenzene & $1 / 15 / 88$ & 10 & & u & $\mathrm{ppb}$ & & \\
\hline $299-W 27-1$ & 1.2.3-trichlorobenzene & $1 / 11 / 90$ & 10 & 4 & $U$ & $\mathrm{ppb}$ & & \\
\hline $299-W 27-1$ & 1.2.4.5-Tetrachlorobenzene & $7 / 24 / 87$ & 10 & & U & $\mathrm{ppb}$ & & \\
\hline $299-W 27-1$ & 1.2.4.5-Tetrachlorobenzene & $10: 15: 87$ & 10 & & U & $\mathrm{ppb}$ & & \\
\hline $299 \cdot W 27-1$ & 1.2.4.5-Tetrachlorobenzene & $1 / 15 / 88$ & 10 & & U & $\mathrm{ppb}$ & & \\
\hline $299-W 27-1$ & 1.2.4.5-Tetrachlorobenzene & $1 / 11 / 90$ & 10 & 4 & U & $\mathrm{ppb}$ & & \\
\hline $299-w 27-1$ & 1.2.4-Trichlorobenzene & $7: 24: 87$ & 10 & & U & $\mathrm{ppb}$ & & \\
\hline
\end{tabular}




\begin{tabular}{|c|c|c|c|c|c|c|c|c|}
\hline Well & Constituent Name & Collect Date & Result & Error Filtered & Qualifier & Units & CRQL & Method Name \\
\hline$\ldots \ldots$ & - n & (........... & $\cdots \cdots$ & $\ldots \ldots$ & 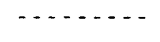 & $\ldots \ldots$ & 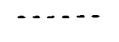 & $\cdots$ \\
\hline $299-W 27-1$ & 1.2.4-Trichlorobenzene & $10 / 15 / 87$ & 10 & & U & $\mathrm{ppb}$ & & \\
\hline $299-W 27-1$ & 1.2.4-Trichlorobenzene & $1 / 15 / 88$ & 10 & & U & $\mathrm{ppb}$ & & \\
\hline $299-W 27-1$ & 1.2.4-Trichlorobenzene & $1 / 11 / 90$ & 10 & 4 & U & $\mathrm{ppb}$ & & \\
\hline 299-W27-1 & 1.2-Dibromo-3-chloropropane & $7 / 24 / 87$ & 10 & & U & $\mathrm{ppb}$ & 5 & SW- 8468240 \\
\hline 299-W27-1 & 1.2-Dibromo-3-chloropropane & $10 / 15 / 87$ & 10 & & U & $\mathrm{ppb}$ & 5 & SW-846 8240 \\
\hline 299-W27-1 & 1.2-Dibromo-3-chloropropane & $1 / 15 / 88$ & 10 & & $U$ & $\mathrm{ppb}$ & 5 & SW-846 8240 \\
\hline 299-W27-1 & 1.2-Dibromo-3-chloropropane & $8 / 18 / 88$ & 10 & &  & $\mathrm{ppb}$ & 5 & SW-846 8240 \\
\hline $299-W 27-1$ & 1.2-Dibromo-3-chloropropane & $1 / 11 / 90$ & 10 & 4 & U & $\mathrm{ppb}$ & 5 & SW-846 8240 \\
\hline $299-W 27-1$ & 1.2-Dibromoethane & $7 / 24 / 87$ & 10 & & U & $\mathrm{ppb}$ & 5 & SW- 8468240 \\
\hline $299-W 27-1$ & 1.2-Dibromoethane & $10 / 15 / 87$ & 10 & & u & $\mathrm{ppb}$ & 5 & SW-846 8240 \\
\hline 299-W27-1 & 1.2-Dibromoethane & $1 / 15 / 88$ & 10 & & $u$ & $\mathrm{ppb}$ & 5 & SW- 8468240 \\
\hline 299-W27-1 & 1.2-Dibromoethane & $8 / 18 / 88$ & 10 & & U & $\mathrm{ppb}$ & 5 & SW-846 8240 \\
\hline $299-W 27-1$ & 1.2-Dibromoethane & $1 / 11 / 90$ & 10 & 4 & U & $\mathrm{ppb}$ & 5 & SW-846 8240 \\
\hline $299-W 27-1$ & 1.2-Dichlorobenzene & $7 / 24 / 87$ & 10 & & U & $\mathrm{ppb}$ & & \\
\hline $299-W 27-1$ & 1.2-Dichlorobenzene & $10 / 15 / 87$ & 10 & & U & $\mathrm{ppb}$ & & \\
\hline $299-W 27-1$ & 1.2-Dichlorobenzene & $1 / 15 / 88$ & 10 & & U & $\mathrm{ppb}$ & & \\
\hline $299-W 27-1$ & 1.2-Dichlorobenzene & $1 / 11 / 90$ & 10 & 4 &  & $\mathrm{ppb}$ & & \\
\hline 299-W27-1 & 1.2-Dichloroethane & $7 / 24 / 87$ & 10 & & U & $\mathrm{ppb}$ & 5 & SW-846 8240 \\
\hline $299-W 27-1$ & 1.2-Dichloroethane & $10,15 / 87$ & 10 & & U & $\mathrm{ppb}$ & 5 & SW- 8468240 \\
\hline 299-W27-1 & 1.2-Dichloroethane & $1 / 15 / 88$ & 10 & & U & $\mathrm{ppb}$ & 5 & SW-846 8240 \\
\hline $299-W 27-1$ & 1.2-Dichloroethane & $8 / 18 / 88$ & 10 & & U & $\mathrm{ppb}$ & 5 & SW-846 8240 \\
\hline $299 \cdot W 27-1$ & 1.2-Dichloroethane & $1 / 11 / 90$ & 5 & 2 & u & $\mathrm{ppb}$ & 5 & SW-846 8240 \\
\hline $299-W 27-1$ & 1.2-Dichloroethane & $4 / 12 / 90$ & 5 & 2 & U & $\mathrm{ppb}$ & 5 & SW-846 8240 \\
\hline $299-W 27-1$ & 1.2-Dichloroethane & $2 / 03 / 92$ & 5 & & U & $\mathrm{ppb}$ & 5 & SW-846 8240 \\
\hline $299 \cdot W 27-1$ & 1.2-Dichloroethane & $3 / 23 / 92$ & 5 & & U & $\mathrm{ppb}$ & 5 & SW-846 8240 \\
\hline $299-W 27-1$ & 1.2-Dichloroethane & $7 / 01 / 92$ & 5 & & U & $\mathrm{ppb}$ & 5 & SW-846 8240 \\
\hline $299-W 27-1$ & 1.2-Dichloroethane & $10 / 27 / 92$ & 5 & & U & ppb & 5 & SW-846 8240 \\
\hline $299-W 27-1$ & 1.2-Dichloroethane & $12 / 29 / 92$ & 5 & & U & ppb & 5 & SW-846 8240 \\
\hline
\end{tabular}




\begin{tabular}{|c|c|c|c|c|c|c|c|c|c|}
\hline Well & Constituent Name & Collect Date & Result & Error & Filtered & Qualifier & Units & CROL & Method Name \\
\hline$\ldots \ldots \ldots$ & 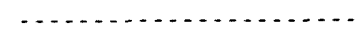 & $\ldots \ldots$ & - - & $\ldots \ldots$ & $\cdots$ & $\ldots \ldots \ldots$ & $\ldots$ & $\cdots$ & ..... \\
\hline 299-W27-1 & 1.2-Dichloroethane & $4 / 12 / 93$ & 5 & & & U & ppb & 5 & SW-846 8240 \\
\hline $299-W 27-1$ & 1.2-Dichloroethene & $4 / 12 / 93$ & 5 & & & U & $\mathrm{ppb}$ & 5 & SW-846 8240 \\
\hline 299-W27-1 & 1.2-Dichloropropane & $7 / 24 / 87$ & 10 & & & $u$ & $\mathrm{ppb}$ & 5 & SW-846 8240 \\
\hline $299-W 27-1$ & 1.2-Dichloropropane & $10 / 15 / 87$ & 10 & & & $u$ & $\mathrm{ppb}$ & 5 & SW-846 8240 \\
\hline 299-W27-1 & 1.2-Dichloropropane & $1 / 15 / 88$ & 10 & & & $U$ & $\mathrm{ppb}$ & 5 & SW-846 8240 \\
\hline 299-W27-1 & 1.2-Dichloropropane & $8 / 18 / 88$ & 10 & & & U & $\mathrm{ppb}$ & 5 & SW-846 8240 \\
\hline $299 \cdot W 27-1$ & 1.2-Dichloropropane & $1 / 11 / 90$ & 5 & 2 & & u & $\mathrm{ppb}$ & 5 & SW-846 8240 \\
\hline 299-W27-1 & 1.2-Dimethylhydrazine & $1 / 11 / 90$ & 10 & 4 & & U & ppb & & SW-846 8240 \\
\hline 299-W27-1 & 1.2-Diphenylhydrazine & $1 / 15 / 88$ & 10 & & & U & $\mathrm{ppb}$ & & \\
\hline $299-W 27-1$ & 1.2-Diphenylhydrazine & $1 / 11 / 90$ & 10 & 4 & & u & $\mathrm{ppb}$ & & \\
\hline 299-W27-1 & 1.3.5-trichlorobenzene & $7 / 24 / 87$ & 10 & & & U & $\mathrm{ppb}$ & & \\
\hline $299-W 27-1$ & 1.3.5-trichlorobenzene & $10 / 15 / 87$ & 10 & & & $U$ & ppb & & \\
\hline 299-W27-1 & 1.3.5-trichlorobenzene & $1 / 15 / 88$ & 10 & & & U & ppb & & \\
\hline 299-W27-1 & 1.3.5-trichlorobenzene & $1 / 11 / 90$ & 10 & 4 & & U & $\mathrm{ppb}$ & & \\
\hline 299-W27-1 & 1.3-Dichlorobenzene & $7 / 24 / 87$ & 10 & & & U & ppb & & \\
\hline $299-w 27-1$ & 1.3-Dichlorobenzene & $10 / 15 / 87$ & 10 & & & U & $\mathrm{ppb}$ & & \\
\hline $299-W 27-1$ & 1.3-Dichlorobenzene & $1 / 15 / 88$ & 10 & & & U & $\mathrm{ppb}$ & & \\
\hline 299-W27-1 & 1.3-Dichlorobenzene & $1 / 11 / 90$ & 10 & 4 & & U & $\mathrm{ppb}$ & & \\
\hline $299-W 27-1$ & 1.3-Dichloropropene & $7 / 24 / 87$ & 10 & & & U & $\mathrm{ppb}$ & & SW-846 8240 \\
\hline $299-W 27-1$ & 1.3-Dichloropropene & $10 / 15 / 87$ & 10 & & & U & $\mathrm{ppb}$ & & SW-846 8240 \\
\hline $299-W 27-1$ & 1.3-Dichloropropene & $1 / 15 / 88$ & 10 & & & U & $\mathrm{ppb}$ & & SW-846 8240 \\
\hline $299-W 27-1$ & 1.3-Dichloropropene & $8 / 18 / 88$ & 10 & & & U & $\mathrm{ppb}$ & & SW-846 8240 \\
\hline $299-W 27-1$ & 1.3-Dichloropropene & $1 / 11 / 90$ & 5 & 2 & & 11 & $\mathrm{ppb}$ & & SW-846 8240 \\
\hline $299-W 27-1$ & 1.4-Dichlorobenzene & $7 / 24 / 87$ & 10 & & & 11 & $\mathrm{ppb}$ & & \\
\hline $299-W 27-1$ & 1.4-Dichlorobenzene & $10 / 15 / 87$ & 10 & & & U & $\mathrm{ppb}$ & & \\
\hline 299. W27-1 & 1.4-Dichlorobenzene & $1 / 15 / 88$ & 10 & & & U & $\mathrm{ppb}$ & & \\
\hline
\end{tabular}




\begin{tabular}{|c|c|c|c|c|c|c|c|c|}
\hline Well & Constituent Name & Collect Date & Result & Error Filtered & Qualifier & Units & CRQL & Method Name \\
\hline ........... & $\ldots$ & $\ldots \ldots \ldots$ & - . . . - & $\ldots \ldots$ & $\ldots \ldots \ldots$ & $\ldots \ldots$ & $\cdots$ & $\ldots \ldots$ \\
\hline 299-W27-1 & 1.4-Dichlorobenzene & $1 / 11 / 90$ & 5 & 2 & U & $\mathrm{ppb}$ & & \\
\hline 299-W27-1 & 1.4-Dichlorobenzene & $1 / 11 / 90$ & 10 & 4 & $\mathrm{U}$ & $\mathrm{ppb}$ & & \\
\hline $299 \cdot W 27-1$ & 1.4-Dichlorobenzene & $4 / 12 / 90$ & 5 & 2 & U & $\mathrm{ppb}$ & & \\
\hline 299-फे27-1 & 1.4-Dichlorobenzene & $2 / 03 / 92$ & 5 & & リ & $\mathrm{ppb}$ & 5 & SW- 8468240 \\
\hline $299-W 27-1$ & 1.4-Dichlorobenzene & $3 / 23 / 92$ & 5 & & $J$ & $\mathrm{ppb}$ & 5 & SW- 8468240 \\
\hline 299-W27-1 & 1.4-Dichlorobenzene & $7 / 01 / 92$ & 5 & & U & $\mathrm{ppb}$ & 5 & SW-846 8240 \\
\hline 299-W27-1 & 1.4-Dichlorobenzene & $10 / 27 / 92$ & 5 & & $u$ & $\mathrm{ppb}$ & 5 & SW-846 8240 \\
\hline 299-W27-1 & 1.4-Dichlorobenzene & $12 / 29 / 92$ & 5 & & U & $\mathrm{ppb}$ & 5 & SW-846 8240 \\
\hline 299-W27-1 & 1.4-Dichlorobenzene & $4 / 12 / 93$ & 5 & & U & $\mathrm{ppb}$ & 5 & SW-846 8240 \\
\hline 299-W27-1 & 1.4-Dioxane & $7 / 24 / 87$ & 500 & & 1 & pib & 200 & SW-846 8240 \\
\hline 299-W27-1 & 1.4-Dioxane & $10 / 15 / 87$ & 500 & & $\mathrm{u}$ & $\mathrm{ppb}$ & 200 & SW-846 8240 \\
\hline $299 \cdot W 27-1$ & 1.4-Dioxane & $1 / 15 / 88$ & 500 & & U & $\mathrm{ppb}$ & 200 & SW-846 8240 \\
\hline 299-W27-1 & 1.4-Dioxane & $8 / 18 / 88$ & 500 & & U & ppb & 200 & SW-846 8240 \\
\hline 299-W27-1 & 1.4-Dioxane & $1 / 11 / 90$ & 500 & 175 & U & $\mathrm{ppb}$ & 200 & SW- 8468240 \\
\hline $299-W 27-1$ & 1.4-Naphtoquinone & $1 / 15 / 88$ & 10 & & 4 & $\mathrm{ppb}$ & & \\
\hline $299-W 27-1$ & 1.4-Naphtoquinone & $1 / 11 / 90$ & 10 & 4 & U & $\mathrm{ppb}$ & & \\
\hline $299-W 27-1$ & 1-(o-Chlorophenyl)thiourea & $1 / 11 / 90$ & 200 & 60 & U & $\mathrm{ppb}$ & & \\
\hline 299-W27-1 & 1-Acetyl-2-thiourea & $1 / 11 / 90$ & 200 & 40 & 1 & $\mathrm{ppb}$ & & \\
\hline 299-W27-1 & 1-Butanol & $1 / 11 / 90$ & 10000 & 3500 & U & $\mathrm{ppb}$ & & \\
\hline $299-W 27-1$ & 1-Butanol & $2 ; 03 / 92$ & 1000 & & U & $\mathrm{ppb}$ & 1000 & SW-846 8240 \\
\hline $299-W 27-1$ & 1-Butanol & $3 / 23 / 92$ & 1000 & & U & $\mathrm{ppb}$ & 1000 & SW-846 8240 \\
\hline $299-W 27-1$ & 1-Butanol & $7 / 01 / 92$ & 1000 & & U & $\mathrm{ppb}$ & 1000 & SW-846 8240 \\
\hline $299-W 27-1$ & 1-Butanol & $10 / 27 / 92$ & 1000 & & U & $\mathrm{ppb}$ & 1000 & SW-846 8240 \\
\hline $299-W 27-1$ & 1-Butanol & $12 / 29 / 92$ & 1000 & & U & $\mathrm{ppb}$ & 1000 & SW-846 8240 \\
\hline $299-W 27-1$ & 1-Butanol & $4 / 12 / 93$ & 1000 & & U & $\mathrm{ppb}$ & 1000 & SW-846 8240 \\
\hline $299-W 27-1$ & 1-Chloro-2.3-epoxypropane & $1 / 15 / 88$ & 10 & & U & $\mathrm{ppb}$ & & \\
\hline
\end{tabular}




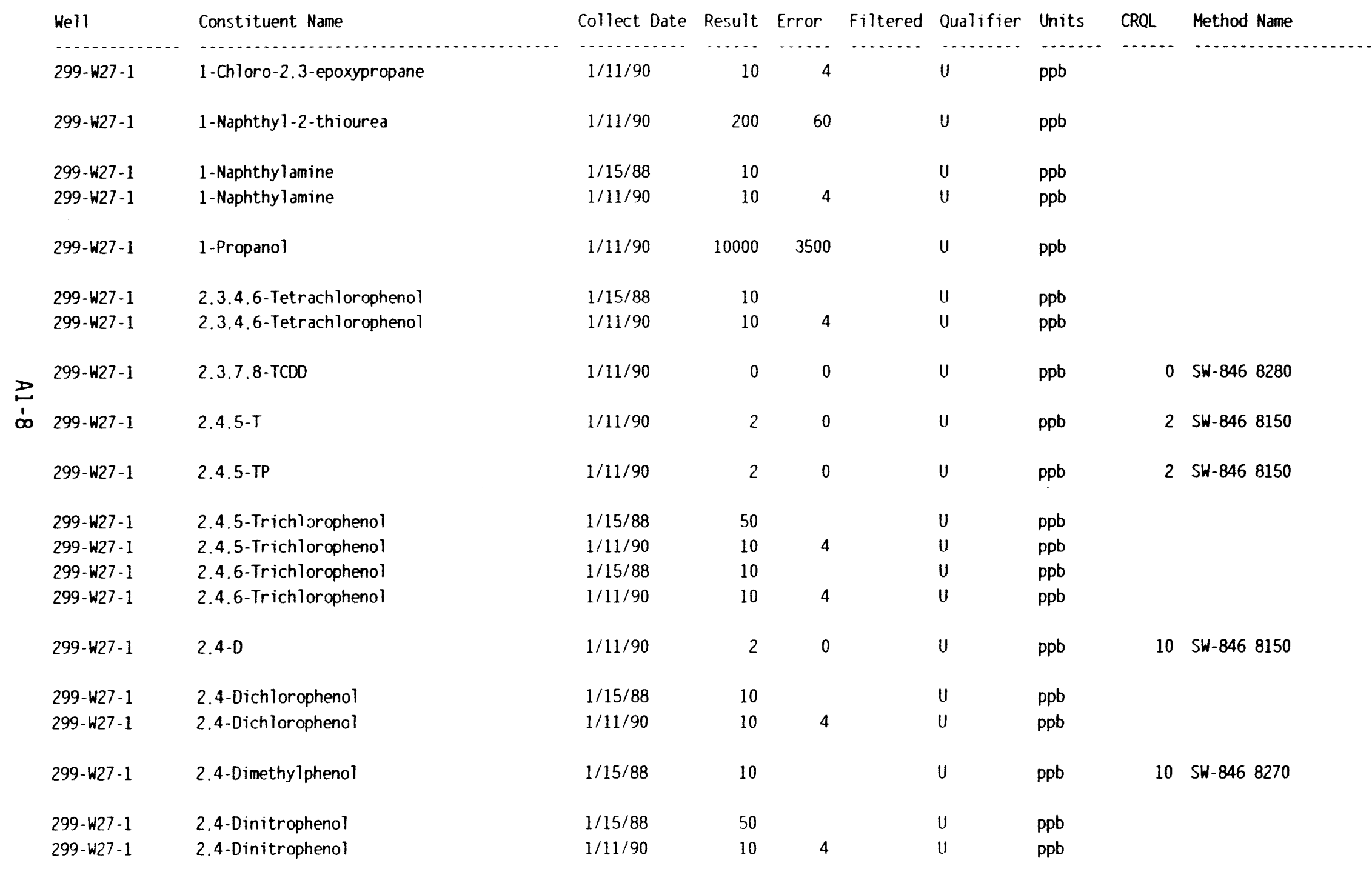




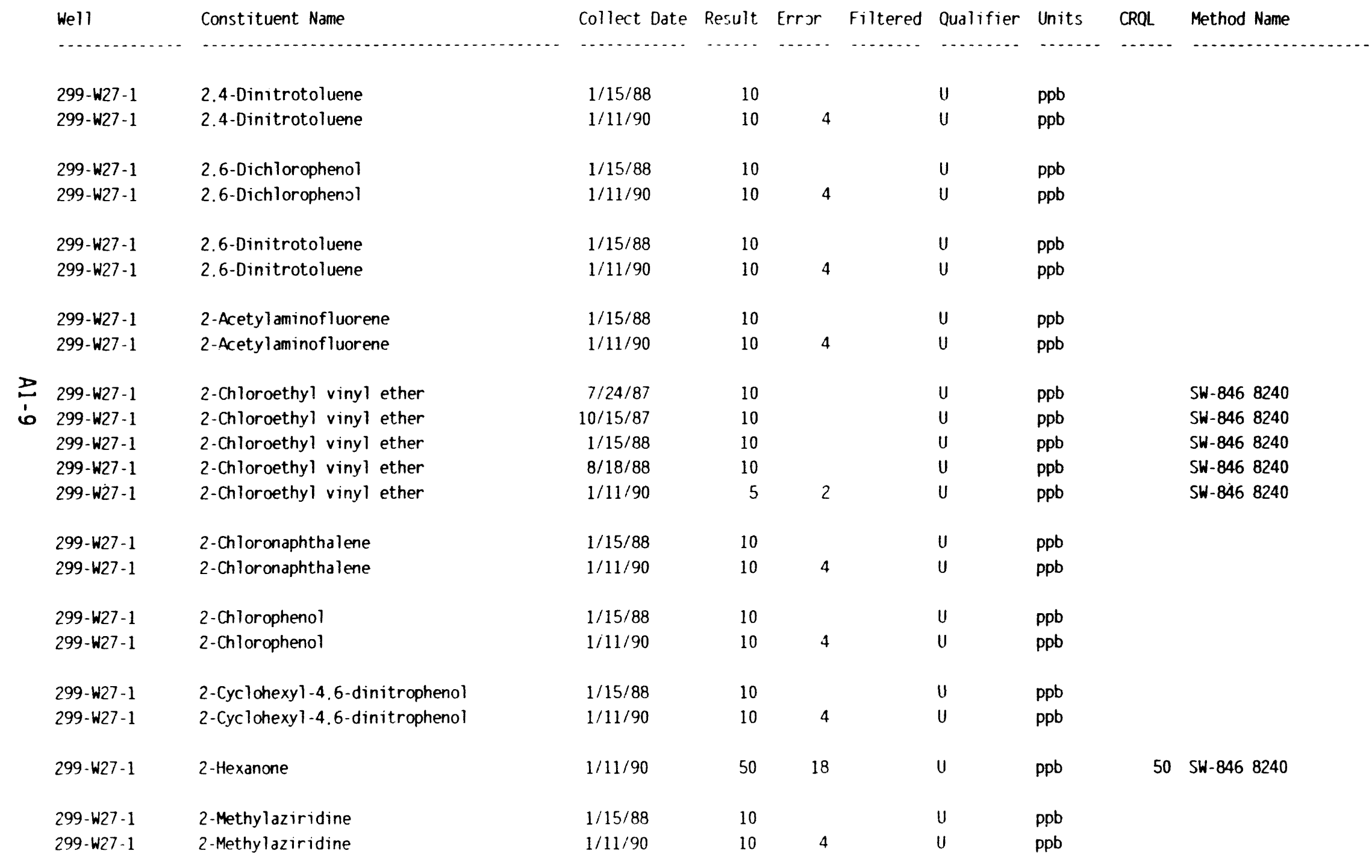




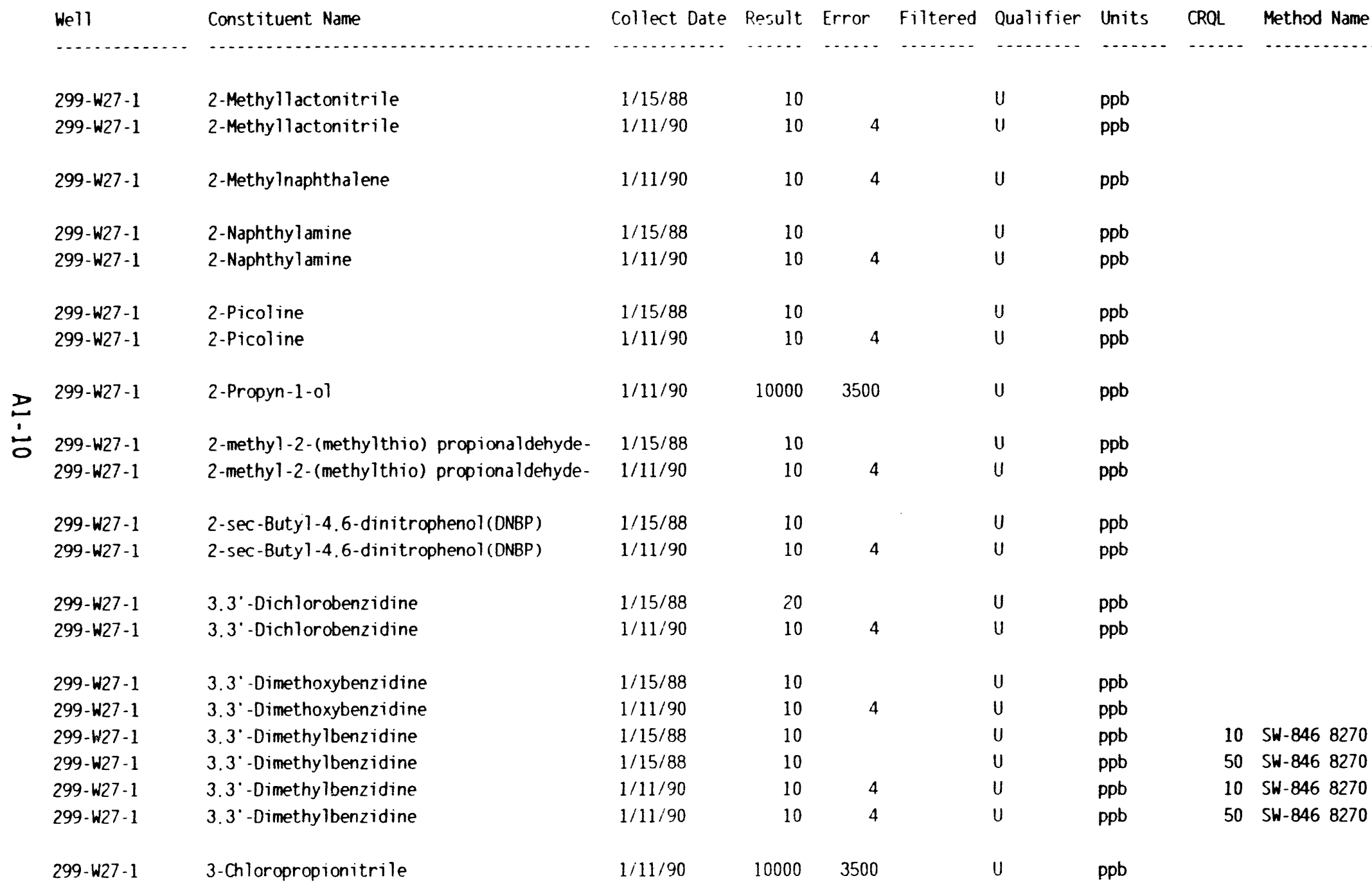









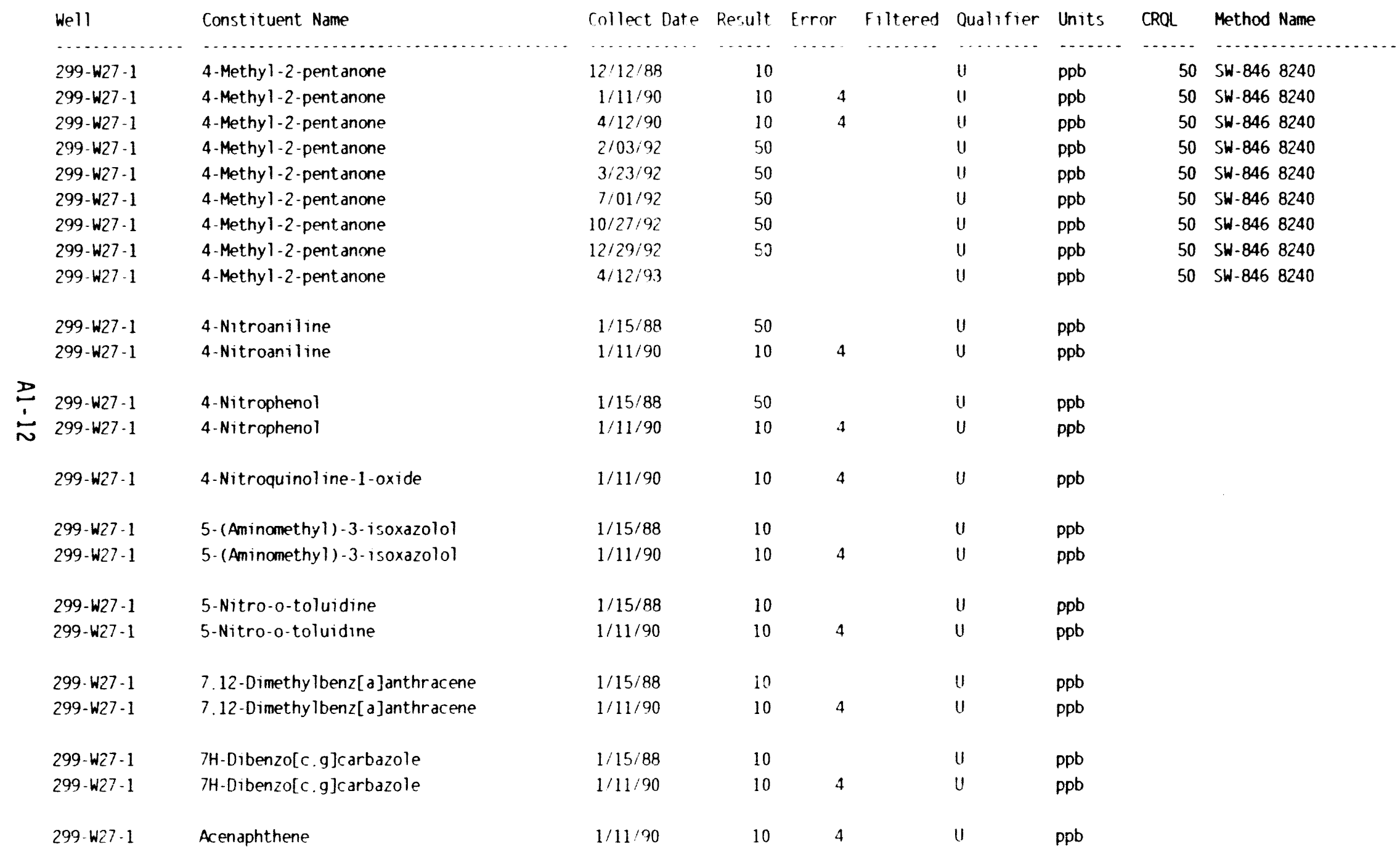







11/08/93 Groundwater Well Results for 299-W27-1 Page 13

\begin{tabular}{|c|c|c|c|c|c|c|c|c|c|}
\hline Well & Constituent Name & Collect Date & Result & Error & Filtered & Qualifier & Units & CROL & Method Name \\
\hline (n................ & (n. & 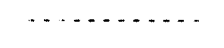 & ..... & ...... & ........ &  & ........ & $\cdots$ & ................ \\
\hline $299-W 27-1$ & Acrylonitrile & $1 / 11 / 90$ & 10 & 4 & & U & $\mathrm{ppb}$ & 5 & SW-846 8240 \\
\hline $299-W 27-1$ & Aldrin & $1 / 11 / 90$ & 0 & 0 & & U & $\mathrm{ppb}$ & 0 & SW-846 8080 \\
\hline $299-W 27-1$ & Alkalinity & $3 / 09 / 87$ & 122000 & & & & $\mathrm{ppb}$ & & \\
\hline $299-W 27-1$ & Alkalinity & $4 / 17 / 87$ & 126000 & & & & $\mathrm{ppb}$ & & \\
\hline $299-W 27-1$ & Alkalinity & $7 / 24 / 87$ & 125000 & & & & $\mathrm{ppb}$ & & \\
\hline $299-W 27-1$ & Alkalinity & $10 / 15 / 87$ & 134000 & & & & $\mathrm{ppb}$ & & \\
\hline $299-W 27-1$ & Alkalinity & $1 / 15 / 88$ & 145000 & & & & $\mathrm{ppb}$ & & \\
\hline $299-W 27-1$ & Alkalinity & $8 / 18 / 88$ & 148000 & & & & $\mathrm{ppb}$ & & \\
\hline $299-W 27-1$ & Alkalinity & $12 / 12 / 88$ & 139000 & & & & $\mathrm{ppb}$ & & \\
\hline $299-W 27-1$ & Allyl alcohol & $1 / 11 / 90$ & 10000 & 3500 & & $\mathrm{U}$ & ppb & & \\
\hline $299-W 27-1$ & Alpha. alpha-Dimethylphenethylamine & $1 / 15 / 88$ & 10 & & & $\mathrm{U}$ & $\mathrm{ppb}$ & & \\
\hline $299-W 27-1$ & Alpha. alpha-Dimethylphenethyl amine & $1 / 11 / 90$ & 10 & 4 & & U & $\mathrm{ppb}$ & & \\
\hline 299-W27-1 & Alpha-BHC & $1 / 11 / 90$ & 0 & 0 & & $U$ & $\mathrm{ppb}$ & 0 & SW-846 8080 \\
\hline $299-W 27-1$ & Aluminum & $3 / 09 / 87$ & 150 & & Y & U & $\mathrm{ppb}$ & 200 & SW-846 6010 \\
\hline 299-W27-1 & Aluminum & $4 / 17 / 87$ & 150 & & $Y$ & $U$ & $\mathrm{ppb}$ & 200 & SH-846 6010 \\
\hline $299-W 27-1$ & Aluminum & $7 / 24 / 87$ & 150 & & Y & U & ppb & 200 & SW-846 6010 \\
\hline $299-W 27-1$ & Aluminum & $10 / 15 / 87$ & 150 & & $Y$ & U & $\mathrm{ppb}$ & 200 & SH-846 6010 \\
\hline $299-W 27-1$ & Aluminum & $1 / 15 / 88$ & 150 & & & U & $p p b$ & & \\
\hline $299-W 27-1$ & Aluminun & $1 / 15 / 88$ & 150 & & $Y$ & U & ppb & 200 & SH-846 6010 \\
\hline $299-W 27-1$ & Aluminum & $8 / 18 / 88$ & 150 & & Y & U & $\mathrm{ppb}$ & 200 & SH-846 6010 \\
\hline 299-W27-1 & Aluminum & $12 / 12 / 88$ & 150 & & r & U & $\mathrm{ppb}$ & 200 & SW-846 6010 \\
\hline $299-W 27-1$ & Aluminum & $1 / 11 / 90$ & 150 & 20 & & U & $\mathrm{ppb}$ & & \\
\hline $299-W 27-1$ & Aluminum & $1 / 11 / 90$ & 150 & 20 & Y & U & $\mathrm{ppb}$ & 200 & SW-846 6010 \\
\hline $299-w 27-1$ & Aluminum & $4 / 12 / 90$ & 150 & 20 & $Y$ & u & $\mathrm{ppb}$ & 200 & SW-846 6010 \\
\hline $299-W 27-1$ & Aluminum & $4 / 12 / 90$ & 150 & 20 & $\gamma$ & U & $\mathrm{ppb}$ & 200 & SW-846 6010 \\
\hline
\end{tabular}


11/08/93 Groundwater Well Results for 299-W27-1 Page 14

\begin{tabular}{|c|c|c|c|c|c|c|c|c|c|}
\hline Well & Const ituent Name & Collect Date & Res.ult & Error & Filtered & Qualifier & Units & CRQL & Method Name \\
\hline $299-$ W27-1 & Americium-241 & $1 / 11 / 90$ & 0 & 0 & $\ldots \ldots$ & $\cdots$ & $\mathrm{pCi} / \mathrm{L}$ & ...... & - \\
\hline $299-w 27-1$ & Amitrole & $1 / 15 / 88$ & 10 & & & u & $\mathrm{ppb}$ & & \\
\hline $299 \cdot W 27-1$ & Amitrole & $1 / 11 / 90$ & 10 & 4 & & U & $\mathrm{ppb}$ & & \\
\hline 299-W27-1 & Armonium ion & $3 / 09 / 87$ & 50 & & & U & $\mathrm{ppb}$ & 100 & ASTM D-1426-D \\
\hline $299 \cdot W 27-1$ & Ammonium ion & $4 / 17 / 87$ & 50 & & & U & $\mathrm{ppb}$ & 100 & ASTM D-1426-D \\
\hline 299-W27-1 & Ammonium ion & $7 / 24 / 87$ & 50 & & & U & $\mathrm{ppb}$ & 100 & ASTM D-1426-D \\
\hline $299-W 27-1$ & Ammonium ion & $10 / 15 / 87$ & 50 & & & U & $\mathrm{ppb}$ & 100 & ASTM D-1426-D \\
\hline $299-W 27-1$ & Ammonium ion & $1 / 15 / 88$ & 50 & & & U & $\mathrm{ppb}$ & 100 & ASTM D-1426-D \\
\hline $299-W 27-1$ & Ammonium ion & $8 / 18 / 88$ & 50 & & & u & $\mathrm{ppb}$ & 100 & ASTM D-1426-D \\
\hline 299-W27-1 & Ammonium ion & $12 / 12 / 88$ & 50 & & & U & $\mathrm{ppb}$ & 100 & ASTM D-1426-D \\
\hline $299-W 27-1$ & Armonium ion & $1 / 11 / 90$ & 50 & 7 & & U & $\mathrm{ppb}$ & 100 & ASTM D-1426-D \\
\hline $299-W 27-1$ & Aniline & $1 / 15 / 88$ & 10 & & & U & $\mathrm{ppb}$ & & \\
\hline $299-W 27-1$ & Aniline & $1 / 11 / 90$ & 10 & 4 & & u & $\mathrm{ppb}$ & & \\
\hline $299-W 27-1$ & Anthracene & $1 / 11 / 90$ & 10 & 4 & & u & $\mathrm{ppb}$ & & \\
\hline $299 \cdot W 27-1$ & Ant imony & $1 / 11 / 90$ & 100 & 14 & & U & $\mathrm{ppb}$ & & \\
\hline 299-W27-1 & Antimony. filtered & $3 / 09 / 87$ & 100 & & Y & U & $\mathrm{ppb}$ & 200 & SW-846 6010 \\
\hline $299-W 27-1$ & Antimony. filtered & $4 / 17 / 87$ & 100 & & Y & U & $\mathrm{ppb}$ & 200 & SW-846 6010 \\
\hline $299-W 27-1$ & Ant imony. filtered & $7 / 24 / 87$ & 100 & & r & U & $\mathrm{ppb}$ & 200 & SW-846 6010 \\
\hline $299-W 27-1$ & Ant imony. filtered & $10 / 15 / 87$ & 100 & & $\gamma$ & U & $\mathrm{ppb}$ & 200 & SW-846 6010 \\
\hline $299-W 27-1$ & Antimony. filtered & $1 / 15 / 88$ & 100 & & $\gamma$ & U & $\mathrm{ppb}$ & 200 & SW-846 6010 \\
\hline 299-W27-1 & Antimony. filtered & $8 / 18 / 88$ & 100 & & Y & U & $\mathrm{ppb}$ & 200 & SW-846 6010 \\
\hline $299-W 27-1$ & Antimony. filtered & $12 / 12 / 88$ & 100 & & Y & U & $\mathrm{ppb}$ & 200 & SW-846 6010 \\
\hline $299-W 27-1$ & Ant imony. filtered & $1 / 11 / 90$ & 100 & 14 & Y & U & $\mathrm{ppb}$ & 200 & SW-846 6010 \\
\hline $299-W 27-1$ & Antimony. filtered & $4 / 12 / 90$ & 100 & 14 & Y & U & $\mathrm{ppb}$ & 200 & SW-846 6010 \\
\hline $299-W 27-1$ & Antimony. filtered & $4 / 12 / 90$ & 100 & 14 & Y & U & $\mathrm{ppb}$ & 200 & SW-846 6010 \\
\hline $299-W 27-1$ & Antimony. filtered & $2 / 03 / 92$ & 200 & & Y & 11 & $\mathrm{ppb}$ & 200 & SW-846 6010 \\
\hline
\end{tabular}









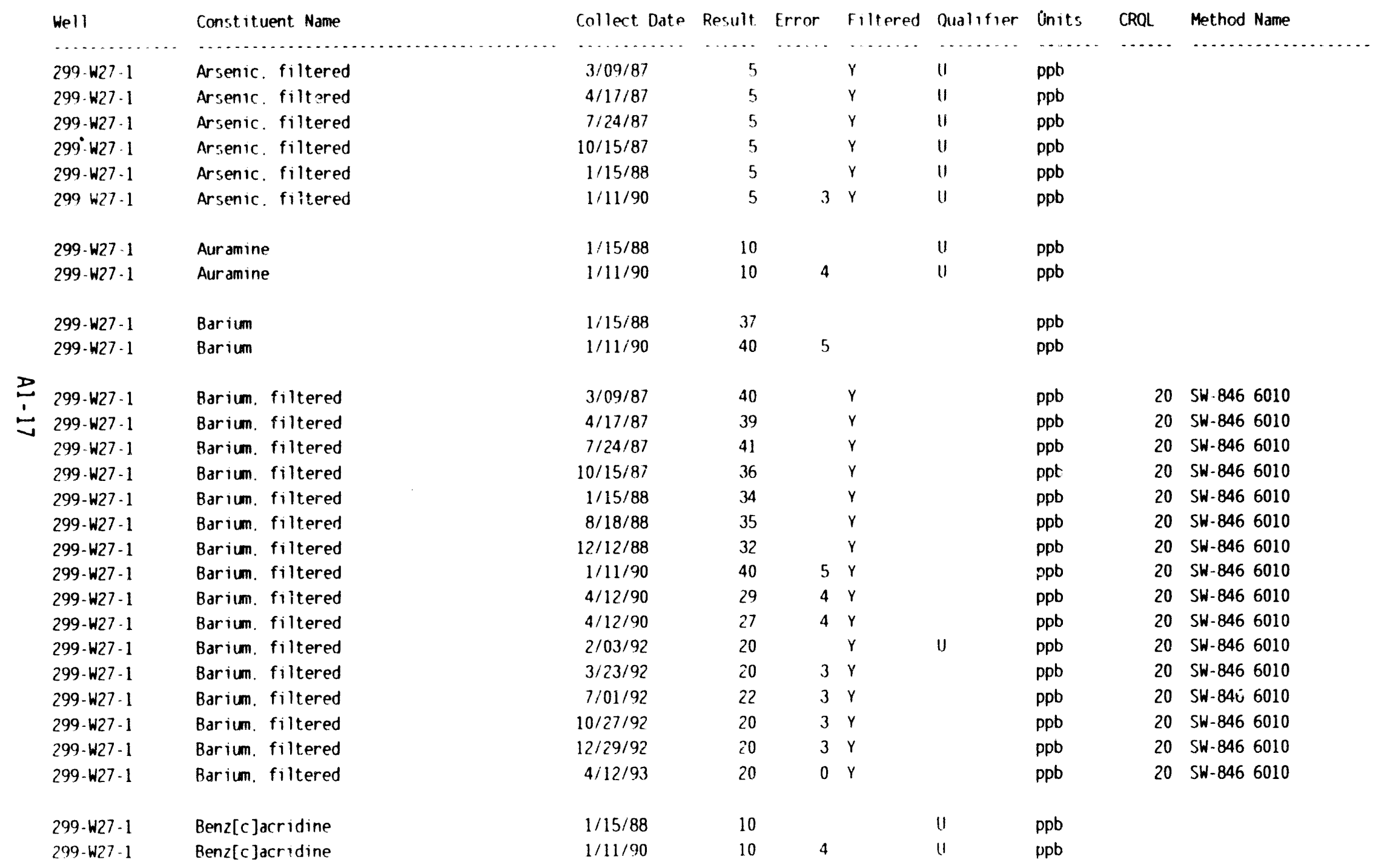









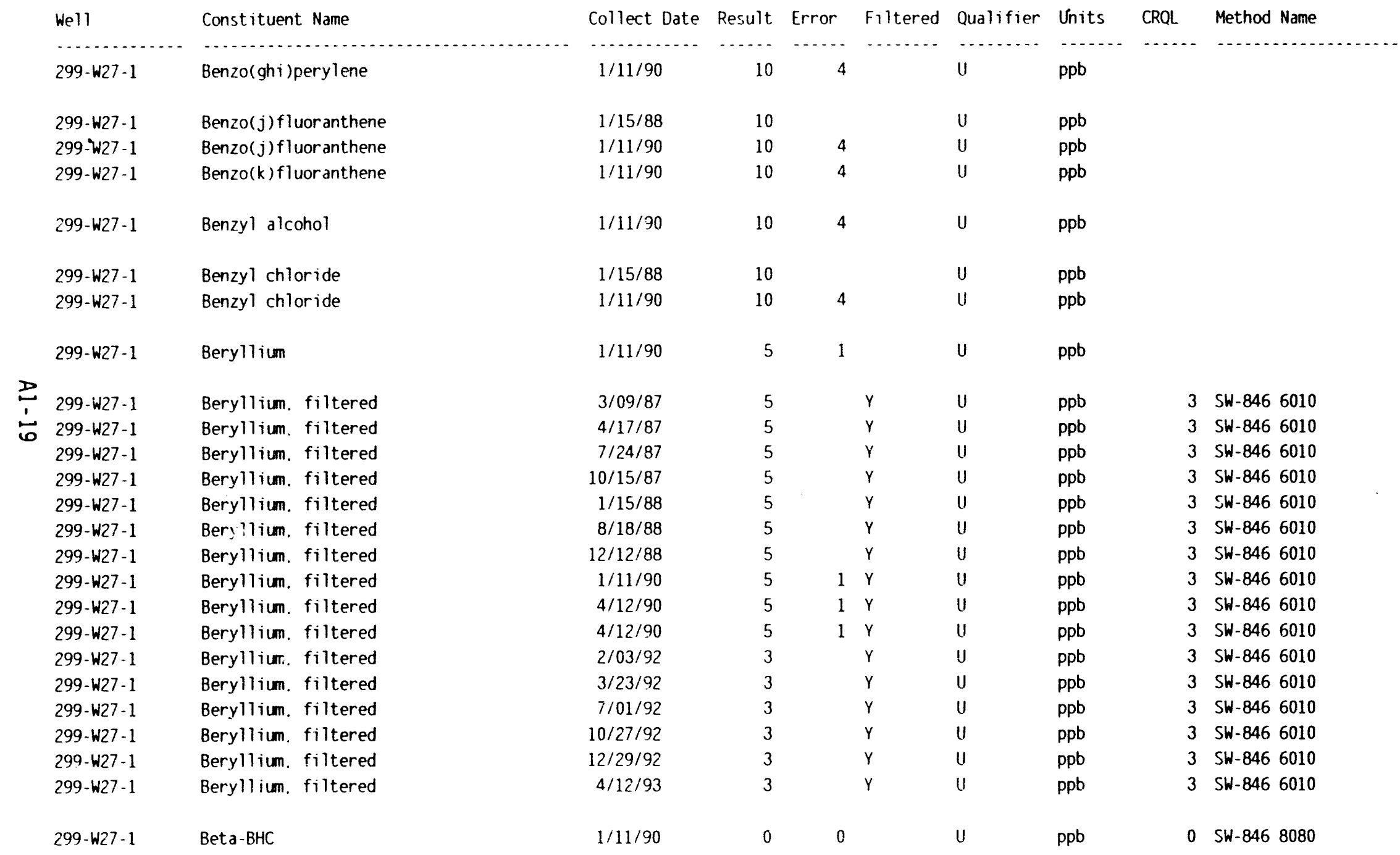




\begin{tabular}{|c|c|c|c|c|c|c|c|c|c|}
\hline Well & Constituent Name & Collect Date & Result & Error & Filtered & Qualifier & Units & CRQL & Method Name \\
\hline$\ldots \ldots$ & (n. & $\ldots \ldots$ & $\ldots$. & $\cdots$ & $\ldots \ldots$ & $\ldots \ldots . .$. & ........ & (n.... & (n............ \\
\hline 299-W27-1 & Bis (2-Choroethoxy)methane & $1 / 15 / 88$ & 10 & & & U & $\mathrm{ppb}$ & & \\
\hline 299-W27-1 & Bis(2-Choroethoxy)methane & $1 / 11 / 90$ & 10 & 4 & & U & $\mathrm{ppb}$ & & \\
\hline 299-W27-1 & Bis(2-chloro-1-methylethyl)ether & $1 / 11 / 90$ & 10 & 4 & & U & $\mathrm{ppb}$ & & \\
\hline 299-W27-1 & Bis(2-chloroethyl) ether & $1 / 15 / 88$ & 10 & & & U & $\mathrm{ppb}$ & & \\
\hline 299-W27-1 & Bis(2-chloroethyl) ether & $1 / 11 / 90$ & 10 & 4 & & U & $\mathrm{ppb}$ & & \\
\hline 299-W27-1 & Bis(2-chloroisopropyl) ether & $1 / 15 / 88$ & 10 & & & u & $\mathrm{ppb}$ & & \\
\hline 299-W27-1 & Bis(2-chloroisopropyl) ether & $1 / 11 / 90$ & 10 & 4 & & u & $\mathrm{ppb}$ & & \\
\hline 299-W27-1 & Bis(2-ethylhexyl) phthalate & $1 / 15 / 88$ & 10 & & & U & $\mathrm{ppb}$ & & \\
\hline 299-W27-1 & Bis(2-ethylhexyl) phthalate & $1 / 11 / 90$ & 10 & 4 & & U & $\mathrm{ppb}$ & & \\
\hline 299-W27-1 & Bis(chloromethyl) ether & $7 / 24 / 87$ & 10 & & & U & $\mathrm{ppb}$ & & SW-846 8240 \\
\hline 299-W27-1 & Bis(chloromethyl) ether & $10 / 15 / 87$ & 10 & & & U & $\mathrm{ppb}$ & & SW-846 8240 \\
\hline 299-W27-1 & Bis(chloromethyl) ether & $1 / 15 / 88$ & 10 & & & U & $\mathrm{ppb}$ & & SW-846 8240 \\
\hline $299-W 27-1$ & Bis(chloromethyl) ether & $8 / 18 / 88$ & 10 & & & u & $\mathrm{ppb}$ & & SW-846 8240 \\
\hline 299-W27-1 & Bis (chloromethyl) ether & $1 / 11 / 90$ & 5 & 2 & & u & $\mathrm{ppb}$ & & SW-846 8240 \\
\hline $299-W 27-1$ & Bismuth & $7 / 24 / 87$ & 5 & & & U & $? ?$ & & \\
\hline 299-W27-1 & Boron & $1 / 11 / 90$ & 30 & 6 & & & $\mathrm{ppb}$ & & \\
\hline $299-W 27-1$ & Boron. filtered & $1 / 11 / 90$ & 32 & 6 & Y & & $\mathrm{ppb}$ & & SW-846 6010 \\
\hline 299-W27-1 & Boron. filtered & $4 / 12 / 90$ & 37 & 6 & Y & & $\mathrm{ppb}$ & & SW-846 6010 \\
\hline 299-W27-1 & Boron. filtered & $4 / 12 / 90$ & 34 & 6 & Y & & $\mathrm{ppb}$ & & SW-846 6010 \\
\hline 299-W27-1 & Bromide & $1 / 11 / 90$ & 1000 & 111 & & u & $\mathrm{ppb}$ & & EPA 300.0 \\
\hline 299-W27-1 & Bromide & $4 / 12 / 90$ & 1000 & 111 & & U & $\mathrm{ppb}$ & & EPA 300.0 \\
\hline 299-W27-1 & Bromide & $4 / 12 / 90$ & 1000 & 111 & & U & $\mathrm{ppb}$ & & EPA 300.0 \\
\hline 299-W27-1 & Bromide & $2 / 03 / 92$ & 500 & & & U & $\mathrm{ppb}$ & 590 & ASTM D-4327-88 \\
\hline
\end{tabular}




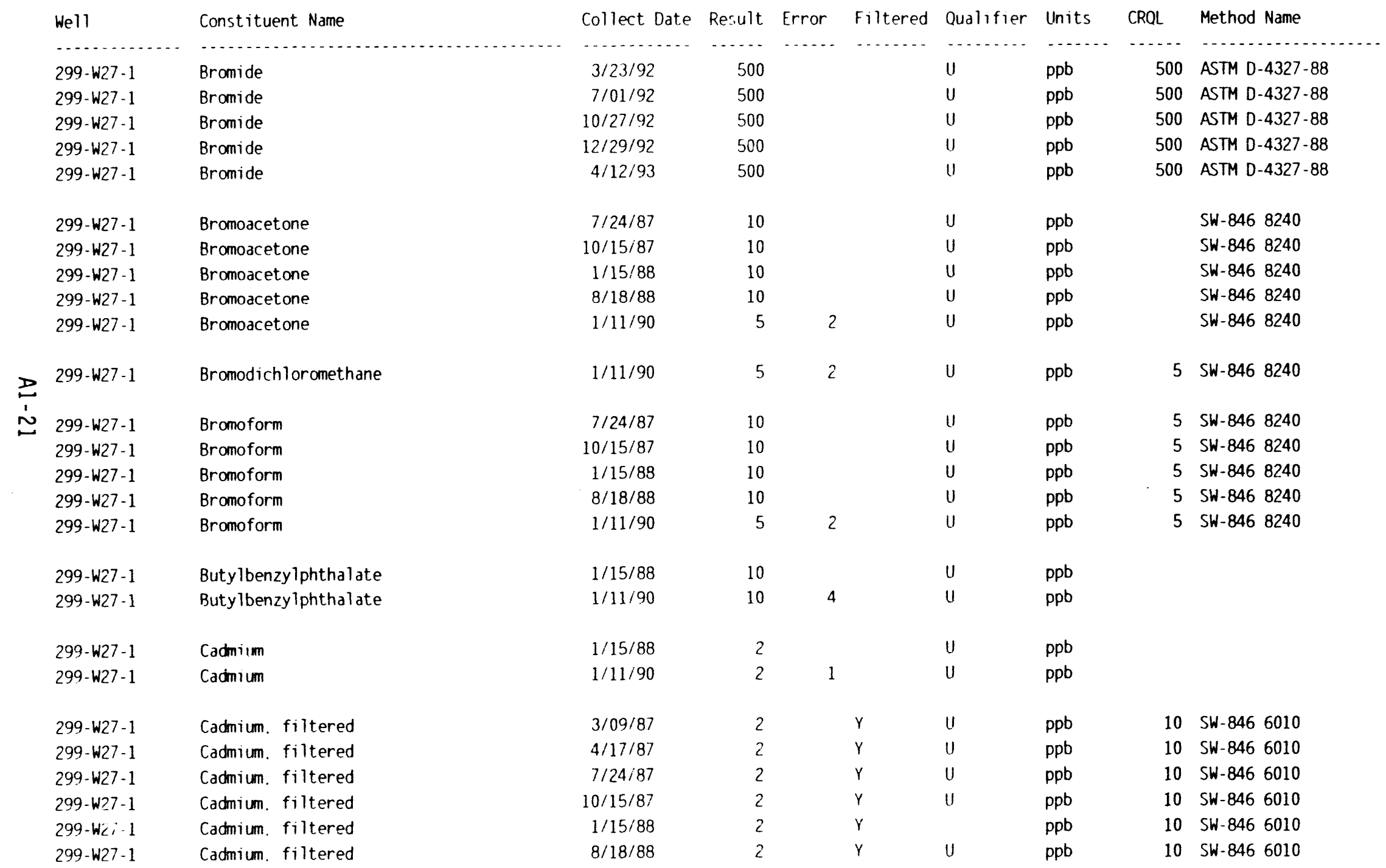




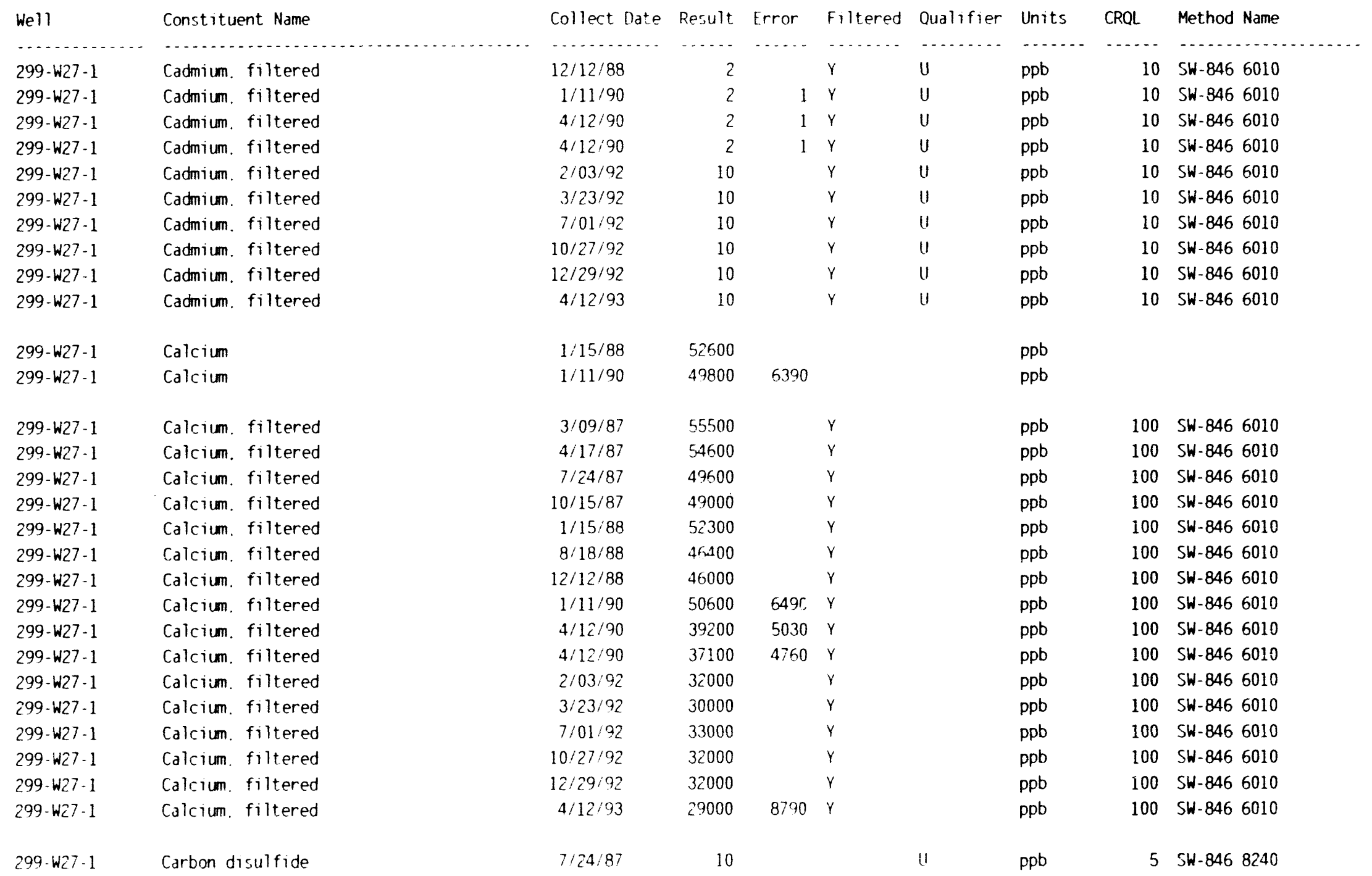




\begin{tabular}{|c|c|c|c|c|c|c|c|c|c|}
\hline Well & Const ituent Name & Collect Date & Result & Error & Filtered & Qualifier & Units & CRQL & Method Name \\
\hline$\cdots$ & $\ldots \ldots$ & $\cdots \ldots \ldots$ & $\cdots \cdots$ & & $\ldots \ldots$ & $\ldots \ldots$ & $\ldots \ldots$ & & $\cdots$ \\
\hline $299-W 27-1$ & Carbon disulfide & $10 / 15 / 87$ & 10 & & & U & $\mathrm{ppb}$ & 5 & SW-846 8240 \\
\hline 299-W27-1 & Carbon disulfide & $1 / 15 / 88$ & 10 & & & U & $\mathrm{ppb}$ & 5 & SW-846 8240 \\
\hline $299-W 27-1$ & Carbon disulfide & $8 / 18 / 88$ & 10 & & & U & $\mathrm{ppb}$ & 5 & SW-846 8240 \\
\hline $299-W 27-1$ & Carbon disulfide & $1 / 11 / 90$ & 10 & 4 & & $\mathrm{U}$ & $\mathrm{ppb}$ & 5 & SW-846 8240 \\
\hline $299-W 27-1$ & Carbon tetrachloride & $3 / 09 / 87$ & 10 & & & U & $\mathrm{ppb}$ & 5 & SW-846 8240 \\
\hline 299-W27-1 & Carbon tetrachloride & $4 / 17 / 87$ & 10 & & & $U$ & $\mathrm{ppb}$ & 5 & SW-846 8240 \\
\hline 299-W27-1 & Carbon tetrachloride & $7 / 24 / 87$ & 10 & & & U & $p p b$ & 5 & SW-846 8240 \\
\hline $299-W 27-1$ & Carbon tetrachloride & $10 / 15 / 87$ & 5 & & & U & $\mathrm{ppb}$ & 5 & $S W-8468240$ \\
\hline 299-W27-1 & Carbon tetrachloride & $1 / 15 / 88$ & 5 & & & U & $\mathrm{ppb}$ & 5 & SW-846 8240 \\
\hline $299-w 27-1$ & Carbon tetrachloride & $8 / 18 / 88$ & 5 & & & u & $\mathrm{ppb}$ & 5 & SW-846 8240 \\
\hline $299-W 27-1$ & Carbon tetrachloride & $12 / 12 / 88$ & 5 & & & U & $\mathrm{ppb}$ & 5 & SW-846 8240 \\
\hline 299-W27-1 & Carbon tetrachloride & $1 / 11 / 90$ & 5 & 2 & & U & $\mathrm{ppb}$ & 5 & SW-846 8240 \\
\hline $299-W 27-1$ & Carbon tetrachloride & $4 / 12 / 90$ & 5 & 2 & & u & $\mathrm{ppb}$ & 5 & SW-846 8240 \\
\hline 299-W27-1 & Carbon tetrachloride & $2 / 03 / 92$ & 5 & & & $u$ & $\mathrm{ppb}$ & 5 & SW-846 8240 \\
\hline 299-W27-1 & Carbon tetrachloride & $3 / 23 / 92$ & 5 & & & u & $\mathrm{ppb}$ & 5 & SW-846 8240 \\
\hline 299-W27-1 & Carbon tetrachloride & $7 / 01 / 92$ & 5 & & & U & $\mathrm{ppb}$ & 5 & SW-846 8240 \\
\hline $299-W 27-1$ & Carbon tetrachloride & $10 / 27 / 92$ & 5 & & & U & $\mathrm{ppb}$ & 5 & SW-846 8240 \\
\hline 299-W27-1 & Carbon tetrachloride & $12 / 29 / 92$ & 5 & & & 4 & $\mathrm{ppb}$ & 5 & SW-846 8240 \\
\hline $299-W 27-1$ & Carbon tetrachloride & $4 / 12 / 93$ & 5 & & & U & $\mathrm{ppb}$ & 5 & SW-846 8240 \\
\hline $299-W 27-1$ & Carbonphenothion & $1 / 11 / 90$ & 2 & 1 & & $u$ & $\mathrm{ppb}$ & & SW-846 8140 \\
\hline $299-W \cdot 27-1$ & Cesium-137 & $10 / 09 / 84$ & 8 & & & & $\mathrm{pCi} / \mathrm{L}$ & & \\
\hline $299-W 27-1$ & Cesium-137 & $11 / 05 / 84$ & -11 & & & & $p C i / L$ & & \\
\hline 299-W27-1 & Cesium-137 & $12 / 06 / 84$ & 5 & & & & $\mathrm{pCi} / \mathrm{L}$ & & \\
\hline 299-W27-1 & Cesium-137 & $1 / 08 / 85$ & 4 & & & & $\mathrm{pCi} / \mathrm{L}$ & & \\
\hline $299-W 27-1$ & Cesium-137 & $4 / 15 / 85$ & 9 & & & & $\mathrm{pCi} / \mathrm{L}$ & & \\
\hline 299-W27-1 & Cesium-137 & $7 / 11 / 85$ & 3 & 3 & & u & $\mathrm{pCi} / \mathrm{L}$ & & \\
\hline $299 \cdot W 27-1$ & Cesium-137 & $10 / 08 / 85$ & 4 & 7 & & U & $\mathrm{pCi} / \mathrm{L}$ & & \\
\hline $299-W 27-1$ & Cesium-137 & $1 / 07 / 86$ & 1 & 1 & & U & $\mathrm{pCi} / \mathrm{L}$ & & \\
\hline $299-w 27-1$ & Cesium-137 & $4 / 07 / 86$ & -18 & 10 & & U & $\mathrm{pCi} / \mathrm{L}$ & & \\
\hline
\end{tabular}




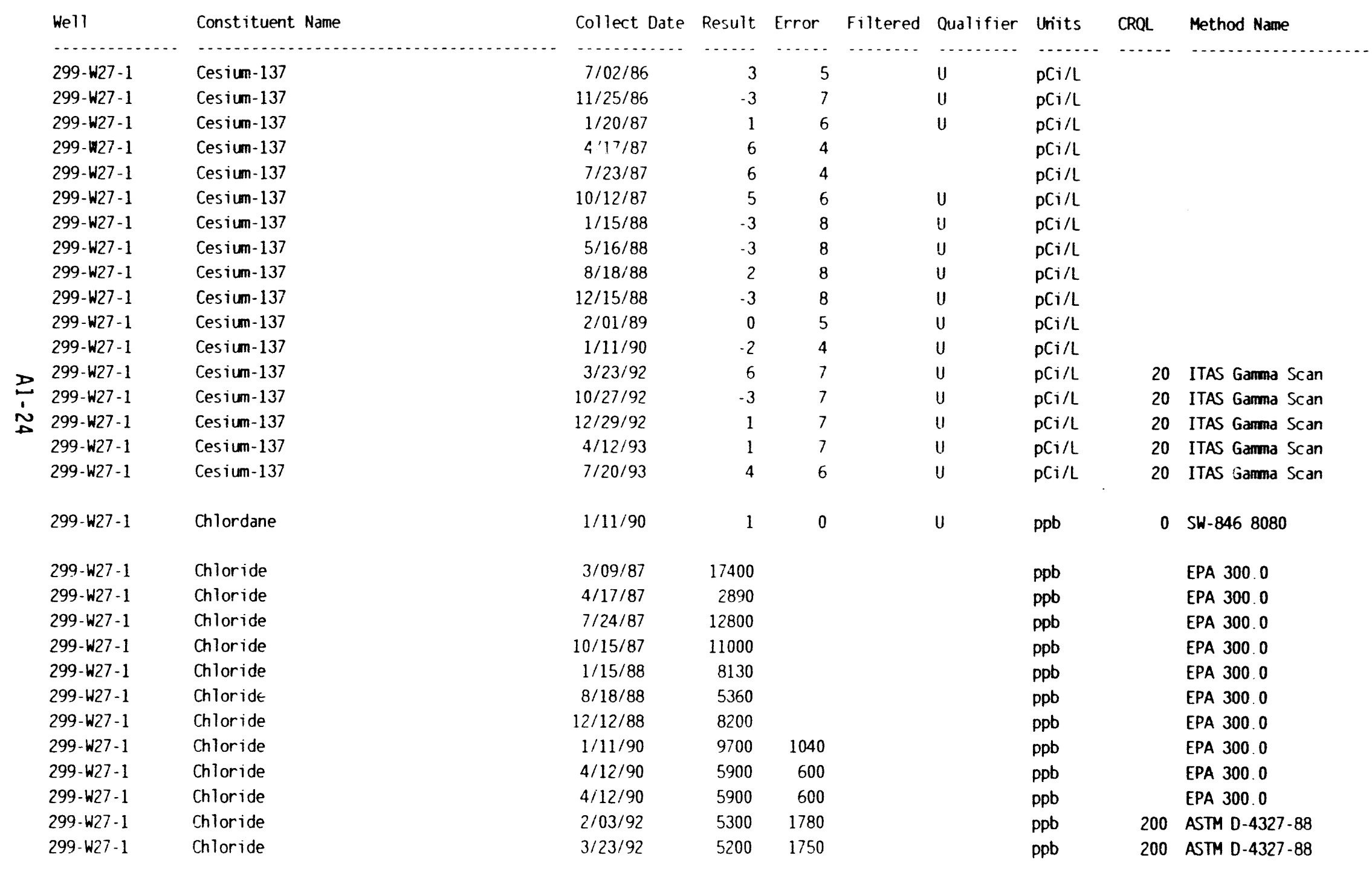




\begin{tabular}{|c|c|c|c|c|c|c|c|c|c|}
\hline Wel1 & Constituent Name & Collect Date & Result & Error & Filtered & Qualifier & Units & CROL & Method Name \\
\hline ......... & - &  & ...... & …... & ........ & $\cdots \ldots$ & - . . n & - n & (n) \\
\hline 299-W27-1 & Chloride & $7 / 01 / 92$ & 5000 & 1680 & & & $\mathrm{ppb}$ & 200 & ASTM D-4327-88 \\
\hline $299-W 27-1$ & Chloride & $10 / 27 / 92$ & 5000 & 1680 & & & ppb & 200 & ASTM $0-4327-88$ \\
\hline 299-W27-1 & Chloride & $12 / 29 / 92$ & 5100 & 1720 & & & $\mathrm{ppb}$ & 200 & ASTM $0-4327-88$ \\
\hline 299-W27-1 & Chloride & $4 / 12 / 93$ & 4500 & 745 & & & $\mathrm{ppb}$ & 200 & ASTM D-4327-88 \\
\hline 299-W27-1 & Chlornaphazine & $1 / 15 / 88$ & 10 & & & u & $\mathrm{ppb}$ & & \\
\hline 299-W27-1 & Chlornaphazine & $1 / 11 / 90$ & 10 & 4 & & U & $\mathrm{ppb}$ & & \\
\hline $299-W 27-1$ & Chloroalkyl ethers & $1 / 15 / 88$ & 10 & & & $\mathrm{U}$ & $\mathrm{ppb}$ & & \\
\hline 299-W27-1 & Chloroalkyl ethers & $1 / 11 / 90$ & 10 & 4 & & U & $\mathrm{ppb}$ & & \\
\hline 299-W27-1 & Chlorobenzene & $7 / 24 / 87$ & 10 & & & U & $\mathrm{ppb}$ & 5 & SW-846 8240 \\
\hline 299-W27-1 & Chlorobenzene & $10 / 15 / 87$ & 10 & & & U & $\mathrm{ppb}$ & 5 & SW-846 8240 \\
\hline $299-W 27-1$ & Chlorobenzene & $1 / 15 / 88$ & 10 & & & u & $\mathrm{ppb}$ & 5 & SW-846 8240 \\
\hline $299-W 27-1$ & Chlorobenzene & $8 / 18 / 88$ & 10 & & & $u$ & $\mathrm{ppb}$ & 5 & SW-846 8240 \\
\hline 299-W27-1 & Chlorobenzene & $1 / 11 / 90$ & 5 & 2 & & U & $\mathrm{ppb}$ & 5 & $5 W-8468240$ \\
\hline $299-W 27-1$ & Chlorobenzene & $1 / 11 / 90$ & 10 & 4 & & U & $\mathrm{ppb}$ & & \\
\hline 299-W27-1 & Chlorobenzene & $2 / 03 / 92$ & 5 & & & $U$ & $\mathrm{ppb}$ & 5 & SW-846 8240 \\
\hline 299-W27-1 & Chlorobenzilate & $1 / 11 / 90$ & 300 & 75 & & U & $\mathrm{ppb}$ & & SW-846 8080 \\
\hline $299-W 27-1$ & Chloroethane & $1 / 11 / 90$ & 10 & 4 & & U & $\mathrm{ppb}$ & 10 & SW-846 8240 \\
\hline $299-W 27-1$ & Chloroform & $3 / 09 / 87$ & 10 & & & $u$ & $\mathrm{ppb}$ & 5 & SW-846 8240 \\
\hline 299-W27-1 & Chloroform & $4 / 17 / 87$ & 10 & & & U & $\mathrm{ppb}$ & 5 & SW-846 8240 \\
\hline $299-W 27-1$ & Chloroform & $7 / 24 / 8 i$ & 10 & & & U & $\mathrm{ppb}$ & 5 & SW-846 8240 \\
\hline $299-W 27-1$ & Chloroform & $10 / 15 / 87$ & 2 & & & u & $\mathrm{ppb}$ & 5 & SW-846 8240 \\
\hline $299-W 27-1$ & Chloroform & $1 / 15 / 88$ & 5 & & & $U$ & $\mathrm{ppb}$ & 5 & SW-846 8240 \\
\hline $299-W 27-1$ & Chloroform & $8 / 18 / 88$ & 6 & & & & $\mathrm{ppb}$ & 5 & SW-846 8240 \\
\hline 299-W27-1 & Chloroform & $12 / 12 / 88$ & 6 & & & & $\mathrm{ppb}$ & 5 & SW-846 8240 \\
\hline $299-W 27-1$ & Chloroform & $1 / 11 / 90$ & 6 & 2 & & & ppb & 5 & SW-846 8240 \\
\hline $299-W 27-1$ & Chiloroform & $4 / 12 / 90$ & 14 & 3 & & & $\mathrm{ppb}$ & 5 & SW-846 8240 \\
\hline
\end{tabular}


Well

299-W27-1

299-W27-1

299-W27-1

$299-W 27-1$

299-W27-1

299-W27-1

299-W27-1

299-W27-1

$299-W 27-1$

299-W27-1

吕
299-W27

Constituent Name

Chloroform

\section{Chloroform}

Chloroform

Chloroform

Chloroform

Chloroform

Chloromethyl methyl ether

Chloromethyl methyl ether

Chloromethyl methyl ether

Chloromethyl methyl ether

Chloromethyl methyl ether

\section{Chromium}

Chromium

299-W27-1

$299-W 27-1$

299-W27-1

299-W27-1

299-W27-1

299-W27-1

299-W27-1

299-W27-1

299-W27-1

299. $W 27-1$

299-W27-1

299-W27-1

299-W27-1

299-W27-1

299-W27-1

299-W27-1
Chromium filtered

Chromium. filtered

Chromium. filtered

Chromium. filtered

Chromium. filtered

Chromium. filtered

Chromium, filtered

Chromium. filtered

Chromium. filtered

Chromium. filtered

Chromium. filtered

Chromium. filtered

Chromium. filtered

Chromium. filtered

Chromium. filtered
Chromium. filtered
Collect Date Rerult Error Filtered Qualifier Inits

$1 / 11 / 90$

$1 / 15 / 88$

$1 / 11 / 90$

$3 / 09 / 87$

$4 / 17 / 87$

$7 / 24 / 87$

$10 / 15 / 87$

$1 / 15 / 88$

$8 / 18 / 88$

$12: 12 / 88$

$1 / 11 / 90$

$4 / 12 / 90$

$4 / 12 / 90$

$2 / 03 / 92$

$3 / 23 / 92$

$7 / 01 / 92$

$10 / 27 / 92$

$12 / 29 / 92$

$4 / 12 / 93$

.......

$p p b$

$\mathrm{ppb}$

$p p b$

$\mathrm{ppb}$

$p p b$

$p p b$

$\mathrm{ppb}$

$p p b$

$\mathrm{ppb}$

ppb

$p p b$

CRQL Method Name

5 SW-846 8240

5 SW-846 8240

5 SW-846 8240

5 SW-846 8240

5 SW-846 8240

5 SW-846 8240

SW-846 8240

SW-846 8240

SW-846 8240

SW-846 8240

SW-846 8240

$\mathrm{ppb}$

$p p b$

$\mathrm{ppb}$

$p p b$

$p p b$

$p p b$

ppb

$p p b$

$\mathrm{ppb}$

$p p b$

$p p b$

$\mathrm{ppb}$

$p p b$

ppb

$p p b$

ppb

ppb

$p p b$

20 SH-846 6010

20 SW-846 6010

20 SW-846 6010

$20 \mathrm{SH}-846 \quad 6010$

20 SH.846 6010

20 SW-846 6010

20 SW-846 6010

20 SH-846 6010

20 SW-846 6010

20 SW-846 6010

20 SW-846 6010

$20 \mathrm{SW}-8466010$

20 SW-846 6010

20 SW-846 6010

20 SH-846 6010

20 SW-846 6010 
Well

Constituent Name

$\begin{array}{ll}\text { 299-W27-1 } & \begin{array}{l}\text { Chrysene } \\ \text { Chrysene }\end{array} \\ \text { 299-W27-1 } & \text { Citrus red No. } 2 \\ \text { 299-W27-1 } & \text { Cobalt } \\ & \\ \text { 299-W27-1 } & \text { Cobalt. filtered } \\ 299-W 27-1 & \text { Cobalt. filtered } \\ 299-W 27-1 & \text { Cobalt. filtered } \\ 299-W 27-1 & \text { Cobalt. filtered } \\ 299-W 27-1 & \text { Cobalt. filtered } \\ 299-W 27-1 & \text { Cobalt. filtered } \\ 299-W 27-1 & \text { Cobalt. filtered } \\ 299-W 27-1 & \text { Cobalt. filtered } \\ 299-W 27-1 & \text { Cobalt. filtered }\end{array}$

299-W27-1

299-W27-1

299-W27-1

299-W27-1

299-W27-1

299-W27-1

299-W27-1

299-W27-1

299-W27-1

299-W27-1

299-W27-1

299-W27-1

299-w27-1

299-W27-1
Cobalt -60

Cobalt-60

Cobalt- 60

Cobalt-60

Cobalt- 60

Cobalt-60

Cobalt-60

Cobalt -60

Cobalt-60

Cobalt -60

Cobalt-60

Cobalt -60

Cobalt-60

Cobalt- 60
Collect Date Result Error Filtered Qualifier Units

CROA Method Name

\begin{tabular}{|c|c|c|c|c|c|c|c|}
\hline $1 / 15 / 88$ & 10 & & & $u$ & $\mathrm{ppb}$ & & \\
\hline $1 / 11 / 90$ & 10 & 4 & & u & $\mathrm{ppb}$ & & \\
\hline $1 / 11 / 90$ & 1000 & 135 & & U & $\mathrm{ppb}$ & & \\
\hline $1 / 11 / 90$ & 20 & 3 & & u & $\mathrm{ppb}$ & & \\
\hline $1 / 11 / 90$ & 20 & 3 & V & u & $\mathrm{ppb}$ & 20 & SW-846 6010 \\
\hline $4 / 12 / 90$ & 20 & 3 & $Y$ & U & $\mathrm{ppb}$ & 20 & SH-846 6010 \\
\hline $4 / 12 / 90$ & 20 & 3 & Y & $u$ & ppb & 20 & SH-846 6010 \\
\hline $2 / 03 / 92$ & 20 & & $\gamma$ & U & ppb & 20 & SH-846 6010 \\
\hline $3 / 23 / 92$ & 20 & & $Y$ & U & $\mathrm{ppb}$ & 20 & SW-846 6010 \\
\hline $7 / 01 / 92$ & 20 & & $Y$ & u & $\mathrm{ppb}$ & 20 & SW-846 6010 \\
\hline $10 / 27 / 92$ & 20 & & $Y$ & $u$ & $\mathrm{ppb}$ & 20 & SW-846 6010 \\
\hline $12 / 29 / 92$ & 20 & & $\gamma$ & u & ppb & 20 & SW-846 6010 \\
\hline $4 / 12 / 93$ & 20 & & $Y$ & U & ppb & 20 & SH-846 6010 \\
\hline
\end{tabular}

$10 / 09 / 84 \quad 8 \quad 2 \mathrm{pCi} / \mathrm{L}$

$11 / 05 / 84 \quad 6$

12/06/84 $-5 \quad \mathrm{pCi} / \mathrm{L}$

$1 / 08 / 85 \quad-3 \quad \mathrm{pCi} / \mathrm{L}$

$4 / 15 / 85 \quad 5$



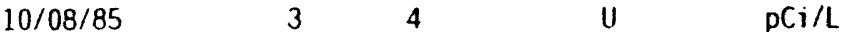

$1.07 / 86 \quad 2 \quad 3 \quad \mathrm{U} \quad \mathrm{pCi} / \mathrm{L}$

$4 / 07 / 86 \quad 0$

$\begin{array}{lllll}7 / 02 / 86 & -4 & 6 & U & \mathrm{pCi} / \mathrm{L}\end{array}$

$11 / 25 / 86 \quad 4 \quad 5040 \quad \mathrm{pCi} / \mathrm{L}$

$1 / 20 / 87 \quad 3 \quad 4 \quad 4 \quad \mathrm{U} \quad \mathrm{pCi} / \mathrm{L}$

$\begin{array}{lllll}4 / 17 / 87 & 1 & 8 & \mathrm{DCi} / \mathrm{L}\end{array}$

$\begin{array}{lllll}7 / 23 / 87 & -3 & 7 & \mathrm{U} & \mathrm{pCi} / \mathrm{L}\end{array}$ 





Well

Constituent Name

Collect Date Result Error Filtered Qualifier Units

...........

$1 / 1588$

299- $-27-1$

Cresols (methviphenols)

$209 \cdot$ W $7 \cdot 1$

Cresols (methylphenols)

\section{W2? - 1}

Crotonaldehyde

299-W27 1

$299-W_{2} 7-1$

Crotonaldehyde

Crotonaldehyde

299. W27-1

Crotonaldehyde

299-W27-1

Crotonaldehyde

299-W27-1

Cyanide

299-W27.1 Cyanide

$D \quad 299 \cdot W 27 \cdot 1$

Cyanide

299-W27-1

Cyanide

299.W27.1

Cyanide

299.627 .

Cyanide

\begin{tabular}{|c|c|}
\hline $299 \cdot w_{2} 7 \cdot 1$ & Delta-BHC \\
\hline $299 \cdot w_{2} 7 \cdot 1$ & Di-n-butylphthalate \\
\hline $299 \cdot W_{2} 7-1$ & Di-n-butylphthalate \\
\hline $299-W 27-1$ & Di-n-octylphthalate \\
\hline $299 \cdot w_{2} 7 \cdot 1$ & Di-n-octylphthalate \\
\hline $299-W 27 \cdot 1$ & Diallate \\
\hline $299-W 27-1$ & Dibenz(a.j)acridine \\
\hline $299-W 27-1$ & Dibenz $(a, j)$ acridine \\
\hline $\left.299 \cdot w_{i}\right) \cdot 1$ & Dibenz[a.h]acridine \\
\hline $299 \cdot W_{c} 7-1$ & Dithenz[a.h]acridine \\
\hline $299 \cdot w_{2} ? \cdot 1$ & Dibenz[a.h]anthr \\
\hline
\end{tabular}

$1 / 11 / 90$

$7 \longdiv { 2 4 : 8 7 }$

$10 / 15 / 87$

$1 / 15 / 88$

8/18/88

1/11:90

$7 / 24 / 87$

$10 / 15 / 87$

1. $15 / 88$

8/18/88

$12 / 12 / 88$

$111 / 90$

$1 / 11 / 90$

1:15/88

$1 / 11 / 90$

$115 / 88$

$1 / 1190$

$1 / 1: / 90$

$1 / 15 / 88$

11190

$1 / 15 / 88$

11190

$1 / 1588$

.....

CROL

Method Name

.................

\section{ppb}

ppb ppb

ppb

$p p b$

ppb

$p p b$

$p p b$

$p p b$

$p p b$

ppo

ppb

ppb

$\mathrm{ppb}$

ppb

$p p b$

ppb

$p p b$

ppb

$10 \quad$ SW- $846 \quad 8270$
SW- 8468240
SW- 8468240
SW. 8468240
SW-846 8240
SW-846 8240

$$
\begin{array}{ccc}
20 & \text { SW-846 } & 9010 \\
20 & \text { SW-846 } & 9010 \\
20 & \text { SW-846 } & 9010 \\
20 & \text { SW-846 } & 9010 \\
20 & \text { SW-846 } & 9010 \\
20 & \text { SW-846 } & 9010 \\
& & \\
0 & \text { SW-846 } & 8080
\end{array}
$$

$p p b$

$p p b$

$p p b$

$p p b$

ppo 







\begin{tabular}{|c|c|c|c|c|c|c|c|c|c|}
\hline Well & Constituent Name & Collect Date & Result & Error & Filtered & Qualifier & Units & CRQL & Method Name \\
\hline … & $\ldots \ldots$ & $\ldots \ldots \ldots$ & $\cdots \cdots$ & ….... & ............. & ................ & (........ & (n...... & (n) \\
\hline $299 \cdot W 27 \cdot 1$ & Diethyl phthalate & $1 / 11 / 90$ & 10 & 4 & & 4 & $\mathrm{ppb}$ & & \\
\hline $299-W 27-1$ & Diethylarsine & $7 / 24 / 87$ & 10 & & & U & $\mathrm{ppb}$ & & \\
\hline $299-W 27-1$ & Diethylarsine & $10 / 15 / 87$ & 10 & & & 11 & $\mathrm{ppb}$ & & \\
\hline $299 \cdot W 27-1$ & Diethylarsine & $1 / 15 / 88$ & 10 & & & 4 & $\mathrm{ppb}$ & & \\
\hline $299 \cdot W 27-1$ & Diethylarsine & $8 / 18 / 88$ & 10 & & & $u$ & ppb & & \\
\hline $299 \cdot W 27 \cdot 1$ & Diethylstilbesterol & $1 / 11 / 90$ & 200 & 40 & & U & ppb & & \\
\hline $299-W 27-1$ & Dihydrosafrole & $1 / 15 / 88$ & 10 & & & U & $\mathrm{ppb}$ & & \\
\hline $299-W 27-1$ & Dihydrosafrole & $1 / 11 / 90$ & 10 & 4 & & U & $\mathrm{ppb}$ & & \\
\hline $299-W 27-1$ & Dimethoate & $1 / 11 / 90$ & 2 & 1 & & U & $\mathrm{ppb}$ & & SW-846 8140 \\
\hline 299-W27-1 & Dimethyl phthalate & $1 / 15 / 88$ & 10 & & & U & $\mathrm{ppb}$ & & \\
\hline $299-W 27-1$ & Dimethyl phthalate & $1 / 11 / 90$ & 10 & 4 & & U & $\mathrm{ppb}$ & & \\
\hline $299-W 27-1$ & Dinoseb & $1 / 11 / 90$ & 10 & 4 & & U & $\mathrm{ppb}$ & & \\
\hline $299-W 27-1$ & Diphenylamine & $1 / 15 / 88$ & 10 & & & U & $\mathrm{ppb}$ & & \\
\hline $299-W 27-1$ & Diphenyl amine & $1 / 11 / 90$ & 10 & 4 & & U & $\mathrm{ppb}$ & & \\
\hline $299-W 27-1$ & Disulfoton & $1 / 11 / 90$ & 2 & 1 & & $U$ & $\mathrm{ppb}$ & 2 & SW-846 8140 \\
\hline $299-W 27-1$ & Endosulfan I & $1 / 11 / 90$ & 0 & 0 & & U & $\mathrm{ppb}$ & 0 & SW-846 8080 \\
\hline $299-W 27-1$ & Endosulfan II & $1 / 11 / 90$ & 0 & 0 & & U & $\mathrm{ppb}$ & 0 & SW-846 8080 \\
\hline 299-W27-1 & Endosulfan sulfate & $1 / 11 / 90$ & 1 & 0 & & U & $\mathrm{ppb}$ & 1 & SW-846 8080 \\
\hline $299-W 27-1$ & Endr in & $1 / 11 / 90$ & 0 & 0 & & $U$ & $\mathrm{ppb}$ & 0 & SW-846 8080 \\
\hline $299 \cdot W 27-1$ & Ethanol & $1 / 11 / 90$ & 10000 & 3500 & & U & $\mathrm{ppb}$ & & \\
\hline
\end{tabular}




\begin{tabular}{|c|c|c|c|c|c|c|c|c|c|}
\hline Well & Const ituent Name & Collect Date & Result & Error & Filtered & Qualifier & Units & CRQL & Method Name \\
\hline$\ldots \ldots$ & (n. &  & -.... & - …- & ….... & (n......... & $\cdots+$ & -.... & (n............ \\
\hline $299-W 27-1$ & Ethyl carbamate (Urethane) & $1 / 11 / 90$ & 10000 & 3500 & & $U$ & $\mathrm{ppb}$ & & \\
\hline 299-W27-1 & Ethyl cyanide & $1 / 11 / 90$ & 10000 & 3500 & & U & $\mathrm{ppb}$ & & \\
\hline 299-W27-1 & Ethyl methacrylate & $7 / 24 / 87$ & 10 & & & U & $\mathrm{ppb}$ & & \\
\hline $299-W 27-1$ & Ethyl methacrylate & $10 / 15 / 87$ & 10 & & & $\mathrm{U}$ & $\mathrm{ppb}$ & & \\
\hline 299-W27-1 & Ethyl methacrylate & $1 / 15 / 88$ & 10 & & & $u$ & $\mathrm{ppb}$ & & \\
\hline $299-W 27-1$ & Ethyl methacrylate & $8 / 18 / 88$ & 10 & & & U & $\mathrm{ppb}$ & & \\
\hline 299-W27-1 & Ethyl methacrylate & $1 / 11 / 90$ & 10 & 4 & & U & $\mathrm{ppb}$ & & \\
\hline 299-W27-1 & Ethyl methanesulfonate & $1 / 15 / 88$ & 10 & & & U & $\mathrm{ppb}$ & & \\
\hline $299-W 27-1$ & Ethyl methanesulfonate & $1 / 11 / 90$ & 10 & 4 & & $u$ & $\mathrm{ppb}$ & & \\
\hline 299-W27-1 & Ethylbenzene & $1 / 11 / 90$ & 5 & 2 & & $\mathrm{U}$ & $\mathrm{ppb}$ & 5 & SW-846 8240 \\
\hline 299-W27-1 & Ethylene Glycol & $1 / 11 / 90$ & 10000 & 3500 & & U & $\mathrm{ppb}$ & & \\
\hline 299-W27-1 & Ethylene oxide & $10 / 15 / 87$ & 3000 & & & U & $\mathrm{ppb}$ & & SW-846 8240 \\
\hline $299-W 27-1$ & Ethylene oxide & $1 / 15 / 88$ & 3000 & & & U & $\mathrm{ppb}$ & & SW-846 8240 \\
\hline 299-W27-1 & Ethylene oxide & $8 / 18 / 88$ & 3000 & & & U & $\mathrm{ppb}$ & & SW-846 8240 \\
\hline 299-W27-1 & Ethylene oxide & $1 / 11 / 90$ & 10 & 4 & & U & $\mathrm{ppb}$ & & SW-846 8240 \\
\hline $299-W 27-1$ & Ethyleneimine & $1 / 15 / 88$ & 10 & & & U & $\mathrm{ppb}$ & & \\
\hline 299-W27-1 & Ethyleneimine & $1 / 11 / 90$ & 10 & $\Delta$ & & $\mathrm{U}$ & $\mathrm{ppb}$ & & \\
\hline 299-W27-1 & Ethylenethiourea & $1 / 11 / 90$ & 200 & 40 & & U & $\mathrm{ppb}$ & & \\
\hline $299-W 27-1$ & Fluor anthene & $1 / 15 / 88$ & 10 & & & u & $\mathrm{ppb}$ & & \\
\hline 299-W27-1 & Fluor anthene & $1 / 11 / 90$ & 10 & 4 & & $\mathrm{U}$ & $\mathrm{ppb}$ & & \\
\hline $299-w 27-1$ & Fluorene & $1 / 11 / 90$ & 10 & 4 & & U & $\mathrm{ppb}$ & & \\
\hline
\end{tabular}




\begin{tabular}{|c|c|c|c|c|c|c|c|c|c|}
\hline Well & Const ituent Name & Collect Date & Result & Error & Filtered & Qualifier & Units & CROL & Method Name \\
\hline$\ldots \ldots \ldots$ & $\ldots \ldots$ & $\cdots$ & $\cdots$ & $\cdots$ & $\cdots \cdots$ & $\cdots \cdots$ & - . . & $\cdots \cdots$ & (1) \\
\hline 299-W27-1 & Fluoride & $2 / 03 / 92$ & 300 & 63 & & & $\mathrm{ppb}$ & 100 & ASTM D-4327-88 \\
\hline $299-W 27-1$ & Fluoride & $3 / 23 / 92$ & 300 & 63 & & & $\mathrm{ppb}$ & 100 & ASTM D-4327-88 \\
\hline 299-W27-1 & Fluoride & $7 / 01 / 92$ & 300 & 63 & & & $\mathrm{ppb}$ & 100 & ASTM D-4327-88 \\
\hline 299-W27-1 & Fluoride & $10 / 27 / 92$ & 300 & 63 & & & $\mathrm{ppb}$ & 100 & ASTM D-4327-88 \\
\hline $299-W 27-1$ & Fluoride & $12 / 29 / 92$ & 400 & 84 & & & $\mathrm{ppb}$ & 100 & ASTM D-4327-88 \\
\hline 299-W27-1 & Fluoride & $4 / 12 / 93$ & 400 & 26 & & & $\mathrm{ppb}$ & 100 & ASTM D-4327-88 \\
\hline 299-W27-1 & Fluorine & $3 / 09 / 87$ & 500 & & & 4 & $\mathrm{ppb}$ & & EPA 300.0 \\
\hline 299-W27-1 & Fluorine & $4 / 17 / 87$ & 500 & & & U & $\mathrm{ppb}$ & & EPA 300.0 \\
\hline 299-W27-1 & Fluorine & $7 / 24 / 87$ & 208 & & & & $p p b$ & & \\
\hline 299-W27-1 & Fluorine & $7 / 24 / 87$ & 500 & & & U & ppb & & EPA 300.0 \\
\hline 299-W27-1 & Fluorine & $10 / 15 / 87$ & 225 & & & & $\mathrm{ppb}$ & & \\
\hline 299-W27-1 & Fluorine & $10 / 15 / 87$ & 506 & & & & $\mathrm{ppb}$ & & EPA 300.0 \\
\hline 299-W27-1 & Fluorine & $1 / 15 / 88$ & 500 & & & U & $\mathrm{ppb}$ & & EPA 300.0 \\
\hline 299-W27-1 & Fluorine & $8 / 18 / 88$ & 267 & & & & ppb & & \\
\hline 299-W27-1 & Fluorine & $8 / 18 / 88$ & 500 & & & U & $\mathrm{ppb}$ & & EPA 300.0 \\
\hline 299-W27-1 & Fluorine & $12 / 12 / 88$ & 500 & & & U & $\mathrm{ppb}$ & & EPA 300.0 \\
\hline 299-W27-1 & Fluorine & $1 / 11 / 90$ & 500 & 56 & & 11 & $\mathrm{ppb}$ & & EPA 300.0 \\
\hline 299-W27-1 & Fluorine & $4 / 12 / 90$ & 500 & 56 & & U & $\mathrm{ppb}$ & & EPA 300.0 \\
\hline 299-W27-1 & Fluorine & $4 / 12 / 90$ & 500 & 56 & & U & $\mathrm{ppb}$ & & EPA 300.0 \\
\hline 299-W27-1 & Formaldehyde & $7 / 24 / 87$ & 500 & & & U & $\mathrm{ppb}$ & & SW-846 8240 \\
\hline 299-W27-1 & Formaldehyde & $10 / 15 / 87$ & 500 & & & 11 & $\mathrm{ppb}$ & & SW-846 8240 \\
\hline 299-W27-1 & Formaldehyde & $1 / 15 / 88$ & 500 & & & U & $p p b$ & & SW-846 8240 \\
\hline 299-W27-1 & Formaldehyde & $8 / 18 / 88$ & 500 & & & U & $\mathrm{ppb}$ & & SW-846 8240 \\
\hline 299-W27-1 & Formaldehyde & $1 / 11 / 90$ & 500 & 175 & & U & $\mathrm{ppb}$ & & SW-846 8240 \\
\hline 299-W27-1 & Gross alpha & $10 / 09 / 84$ & 4 & & & & $\mathrm{pCi} / \mathrm{L}$ & & \\
\hline 299-W27-1 & Gross alpha & $11 / 05 / 84$ & 6 & & & & $\mathrm{pCi} / \mathrm{L}$ & & \\
\hline 299-W27-1 & Gross alpha & $12 / 06 / 84$ & 16 & & & & $\mathrm{pCi} / \mathrm{L}$ & & \\
\hline 299-W27-1 & Gross alpha & $1 / 08 / 85$ & 8 & & & & $\mathrm{pCi} / \mathrm{L}$ & & \\
\hline 299-W27-1 & Gross alpha & $2 / 07 / 85$ & 8 & & & & $\mathrm{pCi} / \mathrm{L}$ & & \\
\hline
\end{tabular}


11/08/93 Groundwater Well Results for 299-W27-1 Page 33

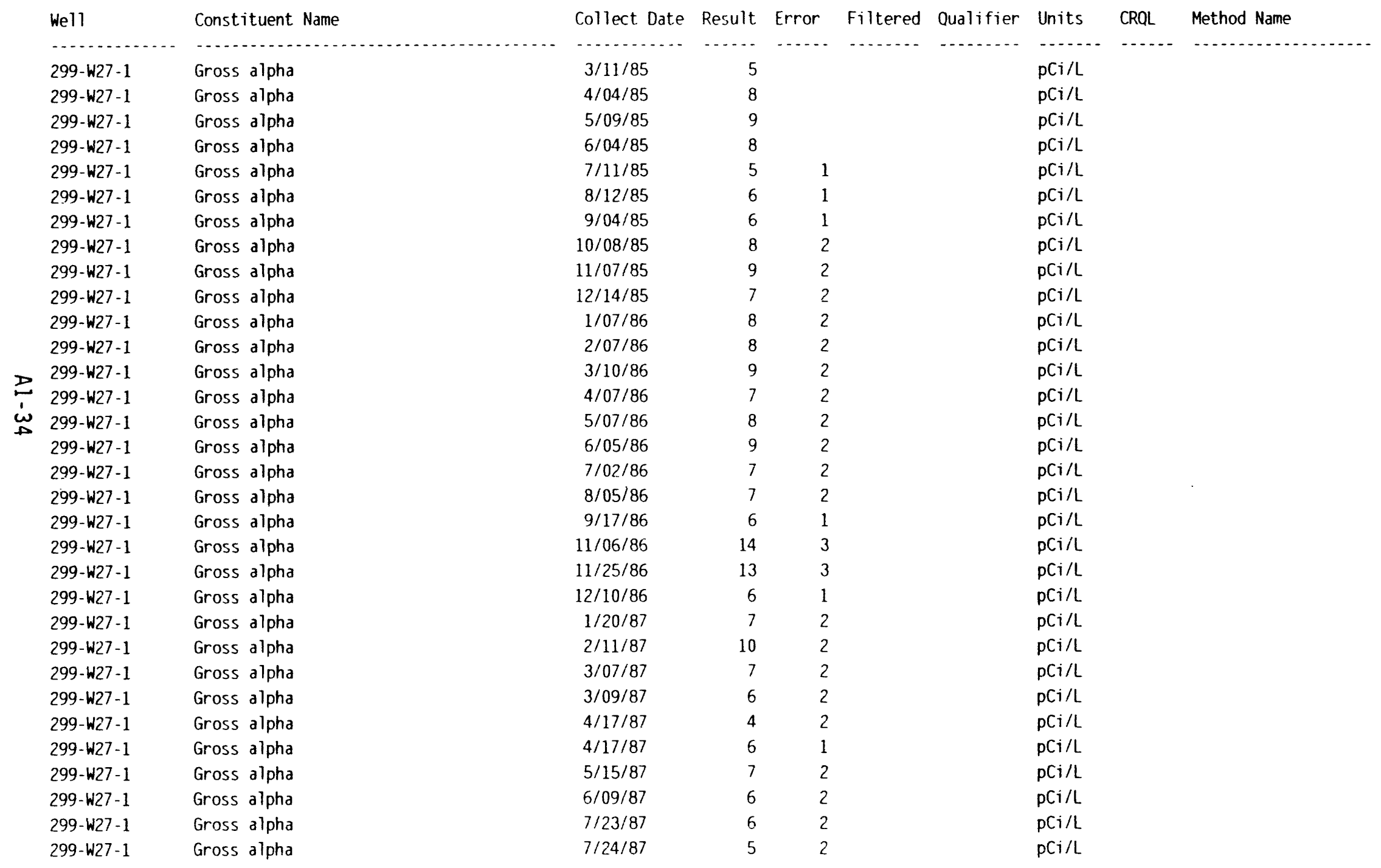




\begin{tabular}{|c|c|c|c|c|c|c|c|c|c|}
\hline Well & Constituent Name & Collect Date & Result & Error & Filtered & Qualifier & Units & $\mathrm{CRQL}$ & Method Name \\
\hline$\ldots \ldots$ & ( & $\ldots$ & $\ldots$. & ...... & $\ldots . .$. & ........... & $\ldots$ & ..... & -........ \\
\hline 299-W27-1 & Gross alpha & $8 / 18 / 87$ & 7 & 2 & & & $\mathrm{pCi} / \mathrm{L}$ & & \\
\hline 299-W27-1 & Gross alpha & $9 / 16 / 87$ & 5 & 1 & & & $\mathrm{pCi} / \mathrm{L}$ & & \\
\hline $299-W 27-1$ & Gross alpha & $10 / 12 / 87$ & 9 & 2 & & & $\mathrm{pCi} / \mathrm{L}$ & & \\
\hline $299-\dot{W} 27-1$ & Gross alpha & $10 / 15 / 87$ & 4 & 2 & & & $\mathrm{pCi} / \mathrm{L}$ & & \\
\hline $299-W 27-1$ & Gross alpha & $11 / 17 / 87$ & 8 & 2 & & & $\mathrm{pCi} / \mathrm{L}$ & & \\
\hline $299-W 27-1$ & Gross alpha & $12 / 08 / 87$ & 9 & 2 & & & $\mathrm{pCi} / \mathrm{L}$ & & \\
\hline 299-W27-1 & Gross alpha & $1 / 15 / 88$ & 11 & 2 & & & $\mathrm{pCi} / \mathrm{L}$ & & \\
\hline 299-W27-1 & Gross alpha & $5 / 16 / 88$ & 13 & 3 & & & $\mathrm{pCi} / \mathrm{L}$ & & \\
\hline 299-W27-1 & Gross alpha & $8 / 18 / 88$ & 5 & 1 & & & $\mathrm{pCi} / \mathrm{L}$ & & \\
\hline 299-W27-1 & Gross alpha & $12 / 15 / 88$ & 9 & 2 & & & $\mathrm{pCi} / \mathrm{L}$ & & \\
\hline $299-W 27-1$ & Gross alpha & $2 / 01 / 89$ & 6 & 3 & & & $\mathrm{pCi} / \mathrm{L}$ & & \\
\hline 299-W27-1 & Gross aipha & $1 / 11 / 90$ & 4 & 2 & & & $\mathrm{pCi} / \mathrm{L}$ & & \\
\hline 299-W27-1 & Gross alpha & $4 / 12 / 90$ & 7 & 3 & & & $\mathrm{pCi} / \mathrm{L}$ & & \\
\hline 299-W27-1 & Gross alpha & $4 / 12 / 90$ & 6 & 3 & & & $\mathrm{pCi} / \mathrm{L}$ & & \\
\hline 299-W27-1 & Gross alpha & $2 / 03 / 92$ & 6 & 3 & & & $\mathrm{pCi} / \mathrm{L}$ & 4 & SW-846 9310. Alpha \\
\hline 299-W27-1 & Gross alpha & 7/01/92 & 2 & 1 & & U & $\mathrm{pCi} / \mathrm{L}$ & 4 & SW-846 9310. Alpha \\
\hline $299-W 27-1$ & Gross alpha & $10 / 27 / 92$ & 4 & 2 & & & $\mathrm{pCi} / \mathrm{L}$ & 4 & SW-846 9310. Alpha \\
\hline 299-W27-1 & Gross alpha & $12 / 29 / 92$ & 10 & 3 & & & $\mathrm{pCi} / \mathrm{L}$ & 4 & SW-846 9310. Alpha \\
\hline 299-W27-1 & Gross alpha & $4 / 12 / 93$ & 5 & 2 & & & $\mathrm{pCi} / \mathrm{L}$ & 4 & SW-846 9310. Alpha \\
\hline 299-W27-1 & Gross alpha & $7 / 20 / 93$ & 4 & 2 & & & $\mathrm{pCi} / \mathrm{L}$ & 4 & SW-846 9310. Alpha \\
\hline 299-W27-1 & Gross beta & $10 / 09 / 84$ & 38 & & & & $\mathrm{pCi} / \mathrm{L}$ & & \\
\hline $299-W 27-1$ & Gross beta & $11 / 05 / 84$ & 23 & & & & $\mathrm{pCi} / \mathrm{L}$ & & \\
\hline 299-W27-1 & Gross beta & $12 / 06 / 84$ & 28 & & & & $\mathrm{pCi} / \mathrm{L}$ & & \\
\hline 299-W27-1 & Gross beta & $1 / 08 / 85$ & 26 & & & & $\mathrm{pCi} / \mathrm{L}$ & & \\
\hline 299-W27-1 & Gross beta & $2 / 07 / 85$ & 34 & & & & $\mathrm{pCi} / \mathrm{L}$ & & \\
\hline $299-W 27-1$ & Gross beta & $3 / 11 / 85$ & 18 & & & & $\mathrm{pCi} / \mathrm{L}$ & & \\
\hline 299-W27-1 & Gross beta & $4 / 04 / 85$ & 26 & & & & $\mathrm{pCi} / \mathrm{L}$ & & \\
\hline $299 \cdot$ - $27-1$ & Gross beta & $5 / 09 / 85$ & 24 & & & & $\mathrm{pCi} / \mathrm{L}$ & & \\
\hline 299-W27-1 & Gross beta & $6 / 04 / 85$ & 19 & & & & $\mathrm{pCi} / \mathrm{L}$ & & \\
\hline $299-W 27-1$ & Gross beta & $7 / 11 / 85$ & 22 & 4 & & & $\mathrm{pCi} / \mathrm{L}$ & & \\
\hline
\end{tabular}




\begin{tabular}{|c|c|c|c|c|c|c|c|c|c|}
\hline Well & Constituent Name & Collect Date & Result & Error & Filtered & Qualifier & Units & CRQL & Method Name \\
\hline ............ & &  & ...... & $\ldots .$. & $\ldots . . .$. & .......... & $\ldots . .$. & $\ldots .$. & ........... \\
\hline 299-W27-1 & Gross beta & $8 / 12 / 85$ & 16 & 3 & & & $\mathrm{pCi} / \mathrm{L}$ & & \\
\hline 299-W27-1 & Gross beta & $9 / 04 / 85$ & 25 & 4 & & & $\mathrm{pCi} / \mathrm{L}$ & & \\
\hline 299-W27-1 & Gross beta & $10 / 08 / 85$ & 15 & 3 & & & $\mathrm{pCi} / \mathrm{L}$ & & \\
\hline 299-พ27-1 & Gross beta & $11 / 07 / 85$ & 23 & 4 & & & $\mathrm{pCi} / \mathrm{L}$ & & \\
\hline 299-W27-1 & Gross beta & $12 / 14 / 85$ & 19 & 4 & & & $\mathrm{pCi} / \mathrm{L}$ & & \\
\hline 299-W27-1 & Gross beta & $1 / 07 / 86$ & 14 & 3 & & & $\mathrm{pCi} / \mathrm{L}$ & & \\
\hline 299-W27-1 & Gross beta & $2 / 07 / 86$ & 17 & 3 & & & $\mathrm{pCi} / \mathrm{L}$ & & \\
\hline 299-W27-1 & Gross beta & $3 / 10 / 86$ & 17 & 3 & & & $\mathrm{pCi} / \mathrm{L}$ & & \\
\hline 299-W27-1 & Gross beta & $4 / 07 / 86$ & 9 & 3 & & & $\mathrm{pCi} / \mathrm{L}$ & & \\
\hline 299-W27-1 & Gross beta & $5 / 07 / 86$ & 9 & 3 & & & $\mathrm{pCi} / \mathrm{L}$ & & \\
\hline 299-W27-1 & Gross beta & $6 / 05 / 86$ & 7 & 2 & & & $\mathrm{pCi} / \mathrm{L}$ & & \\
\hline 299-W27-1 & Gross beta & $7 / 02 / 86$ & 9 & 3 & & & $\mathrm{pCi} / \mathrm{L}$ & & \\
\hline 299-W27-1 & Gross beta & $8 / 05 / 86$ & 8 & 2 & & & $\mathrm{pCi} / \mathrm{L}$ & & \\
\hline 299-W27-1 & Gross beta & $9 / 17 / 86$ & 9 & 3 & & & $\mathrm{pCi} / \mathrm{L}$ & & \\
\hline 299-W27-1 & Gross beta & $11 / 06 / 86$ & 10 & 3 & & & $\mathrm{pCi} / \mathrm{L}$ & & \\
\hline 299-W27-1 & Gross beta & $11 / 25 / 86$ & 11 & 3 & & & $\mathrm{pCi} / \mathrm{L}$ & & \\
\hline 299-W27-1 & Gross beta & $12 / 10 / 86$ & 10 & 3 & & & $\mathrm{pCi} / \mathrm{L}$ & & \\
\hline 299-W27-1 & Gross beta & $1 / 20 / 87$ & 10 & 3 & & & $\mathrm{pCi} / \mathrm{L}$ & & \\
\hline 299-W27-1 & Gross beta & $2 / 11 / 87$ & 7 & 2 & & & $\mathrm{pCi} / \mathrm{L}$ & & \\
\hline 299-W27-1 & Gross beta & $3 / 07 / 87$ & 7 & 2 & & & $\mathrm{pCi} / \mathrm{L}$ & & \\
\hline 299-W27-1 & Gross beta & $3 / 09 / 87$ & 12 & 4 & & & $\mathrm{pCi} / \mathrm{L}$ & & \\
\hline 299-W27-1 & Gross beta & $4 / 17 / 87$ & 11 & 4 & & & $\mathrm{pCi} / \mathrm{L}$ & & \\
\hline 299-W27-1 & Gross beta & $4 / 17 / 87$ & 7 & 2 & & & $\mathrm{pCi} / \mathrm{L}$ & & \\
\hline 299-W27-1 & Gross beta & $5 / 15 / 87$ & 6 & 2 & & & $\mathrm{pCi} / \mathrm{L}$ & & \\
\hline 299-W27-1 & Gross beta & $6 / 09 / 87$ & 8 & 2 & & & $\mathrm{pCi} / \mathrm{L}$ & & \\
\hline 299-W27-1 & Gross beta & $7 / 23 / 87$ & 9 & 2 & & & $\mathrm{pCi} / \mathrm{L}$ & & \\
\hline 299-W27-1 & Gross beta & $7 / 24 / 87$ & 35 & 9 & & & $\mathrm{pCi} / \mathrm{L}$ & & \\
\hline 299-W27-1 & Gross beta & $8 / 18 / 87$ & 6 & 2 & & & $\mathrm{pCi} / \mathrm{L}$ & & \\
\hline 299-W27-1 & Gross beta & $9 / 16 / 87$ & 8 & 2 & & & $\mathrm{pCi} / \mathrm{L}$ & & \\
\hline $299-W 27-1$ & Gross beta & $10 / 12 / 87$ & 6 & 2 & & & $\mathrm{pCi} / \mathrm{L}$ & & \\
\hline 299-W27-1 & Gross beta & $10 / 15 \prime 87$ & 8 & 5 & & & $\mathrm{pCi} / \mathrm{L}$ & & \\
\hline 299-W27-1 & Gross beta & $11 / 17 / 87$ & 8 & 2 & & & $\mathrm{pCi} / \mathrm{L}$ & & \\
\hline
\end{tabular}




\begin{tabular}{|c|c|c|c|c|c|c|c|c|c|}
\hline Well & Constituent Name & Collect Date & Result & Error & Filtered & Qualifier & Units & CRQL & Method Name \\
\hline$\ldots$ & (n) & $\ldots$ & $\ldots$. & $\ldots \ldots$ & $\ldots \ldots$ & n.......... & $\ldots$ & $\cdots$ & $\cdots$ \\
\hline $299-W 27-1$ & Gross beta & $12 / 08 / 87$ & 9 & 2 & & & $\mathrm{pCi} / \mathrm{L}$ & & \\
\hline 299-W27-1 & Gross beta & $1 / 15 / 88$ & 9 & 3 & & & $\mathrm{pCi} / \mathrm{L}$ & & \\
\hline $299-W 27-1$ & Gross beta & $5 / 16 / 88$ & 8 & 2 & & & $\mathrm{pCi} / \mathrm{L}$ & & \\
\hline 299-W27-1 & Gross beta & $8 / 18 / 88$ & 10 & 3 & & & $\mathrm{pCi} / \mathrm{L}$ & & \\
\hline 299-W27-1 & Gross beta & $12 / 15 / 88$ & 9 & 3 & & & $\mathrm{pCi} / \mathrm{L}$ & & \\
\hline 299-W27-1 & Gross beta & $2 / 01 / 89$ & 5 & 3 & & & $\mathrm{pCi} / \mathrm{L}$ & & \\
\hline $299-W 27-1$ & Gross beta & $1 / 11 / 90$ & 6 & 3 & & & $\mathrm{pCi} / \mathrm{L}$ & & \\
\hline $299-W 27-1$ & Gross beta & $4 / 12 / 90$ & 6 & 3 & & & $\mathrm{pCi} / \mathrm{L}$ & & \\
\hline $299-W 27-1$ & Gross beta & $4 / 12 / 90$ & 7 & 3 & & & $\mathrm{pCi} / \mathrm{L}$ & & \\
\hline $299-W 27-1$ & Gross beta & $2 / 03 / 92$ & 9 & 3 & & & $\mathrm{pCi} / \mathrm{L}$ & 8 & SW-846 9310. Beta \\
\hline $299-W 27-1$ & Gross beta & $3 / 23 / 92$ & 2 & 2 & & U & $\mathrm{pCi} / \mathrm{L}$ & 8 & SW-846 9310. Beta \\
\hline $299-W 27-1$ & Gross beta & $7 / 01 / 92$ & 9 & 3 & & & $\mathrm{pCi} / \mathrm{L}$ & 8 & SW-846 9310. Beta \\
\hline $299-W 27-1$ & Gross beta & $10 / 27 / 92$ & 5 & 2 & & U & $\mathrm{pCi} / \mathrm{L}$ & 8 & SW-846 9310. Beta \\
\hline $299-W 27-1$ & Gross beta & $12 / 29 / 92$ & 11 & 3 & & & $\mathrm{pCi} / \mathrm{L}$ & 8 & SW-846 9310. Beta \\
\hline $299-W 27-1$ & Gross beta & $4 / 12 / 93$ & 8 & 3 & & U & $\mathrm{pCi} / \mathrm{L}$ & 8 & SW-846 9310. Beta \\
\hline $299-W 27-1$ & Gross beta & $7 / 20 / 93$ & 9 & 3 & & & $\mathrm{pCi} / \mathrm{L}$ & 8 & SW-846 9310. Beta \\
\hline $299-W 27-1$ & Heptachlor & $1 / 11 / 90$ & 0 & 0 & & U & $\mathrm{ppb}$ & 0 & SW-846 8080 \\
\hline $299-W 27-1$ & Heptachlor epoxide & $1 / 11 / 90$ & 0 & 0 & & U & $\mathrm{ppb}$ & 1 & SW-846 8080 \\
\hline 299-W27-1 & Hexachlorobenzene & $7 / 24 / 87$ & 10 & & & U & $\mathrm{ppb}$ & & \\
\hline 299-W27-1 & Hexachlorobenzene & $10 / 15 / 87$ & 10 & & & U & $\mathrm{ppb}$ & & \\
\hline $299-W 27 \cdot 1$ & Hexachlorobenzene & $1 / 15 / 88$ & 10 & & & U & $\mathrm{ppb}$ & & \\
\hline $299-W 27-1$ & Hexachlorobenzene & $1 / 11 / 90$ & 10 & 4 & & U & $\mathrm{ppb}$ & & \\
\hline $299-W 27-1$ & Hexachlorobutadiene & $1 / 15 / 88$ & 10 & & & " & $\mathrm{ppb}$ & & \\
\hline $299-W 27-1$ & Hexachlorobutadiene & $1 / 11 / 90$ & 10 & 4 & & $y$ & $\mathrm{ppb}$ & & \\
\hline $299-W 27-1$ & Hexachlorocyclopentadiene & $1 / 15 / 88$ & 10 & & & U & $\mathrm{ppb}$ & & \\
\hline 299-W27-1 & Hexachlorocyclopentadiene & $1 / 11 / 90$ & 10 & 4 & & U & $\mathrm{ppb}$ & & \\
\hline
\end{tabular}


11/08/93 Groundwater Well Results for 299-W27-1 Page 37

\begin{tabular}{|c|c|c|c|c|c|c|c|c|c|}
\hline Well & Constituent Name & Collect Date & Result & Error & Filtered & Qualifier & Units & CRQL & Method Name \\
\hline $299-W 27-1$ & Hexachloroethane & $1 / 15 / 88$ & 10 & ..... & . & $u$ & $\mathrm{ppb}$ & & \\
\hline 299-W27-1 & Hexachloroethane & $1 / 11 / 90$ & 10 & 4 & & u & $\mathrm{ppb}$ & & \\
\hline 299-W27-1 & Hexachlorophene & $7 / 24 / 87$ & 10 & & & $u$ & $\mathrm{ppb}$ & & \\
\hline 299-W27-1 & Hexachlorophene & $10 / 15 / 87$ & 10 & & & u & $\mathrm{ppb}$ & & \\
\hline 299-W27-1 & Hexachlorophene & $1 / 15 / 88$ & 10 & & & $u$ & $p p b$ & & \\
\hline 299-W27-1 & Hexachlorophene & $1 / 11 / 90$ & 10 & 4 & & u & $\mathrm{ppb}$ & & \\
\hline 299-W27-1 & Hexachloropropene & $1 / 15 / 88$ & 10 & & & $u$ & $\mathrm{ppb}$ & & \\
\hline 299-W27-1 & Hexachloropropene & $1 / 11 / 90$ & 10 & 4 & & $u$ & $\mathrm{ppb}$ & & \\
\hline 299-W27-1 & Hydrazine & $1 / 11 / 90$ & 30 & 5 & & u & $\mathrm{ppb}$ & 30 & ASTM D-1385 \\
\hline 299-W27-1 & Hydrogen sulfide & $7 / 24 / 87$ & 10 & & & u & $\mathrm{ppb}$ & & \\
\hline 299-W27-1 & Hydrogen sulfide & $10 / 15 / 87$ & 10 & & & $u$ & $\mathrm{ppb}$ & & \\
\hline 299-W27-1 & Hydrogen sulfide & $1 / 15 / 88$ & 10 & & & u & $\mathrm{ppb}$ & & \\
\hline $299-W 27-1$ & Hydrogen sulfide & $8 / 18 / 88$ & 10 & & & $u$ & $\mathrm{ppb}$ & & \\
\hline 299-W27-1 & Indeno(1.2.3-cd)pyrene & $1 / 15 / 88$ & 10 & & & $u$ & $\mathrm{ppb}$ & & \\
\hline 299-W27-1 & Indeno(1.2.3-cd)pyrene & $1 / 11 / 90$ & 10 & 4 & & u & $\mathrm{ppb}$ & & \\
\hline $299-W 27-1$ & Iodine-129 & $4 / 12 / 90$ & 0 & 0 & & & $\mathrm{pCi} / \mathrm{L}$ & & \\
\hline 299-W27-1 & Iodine-129 & $4 / 12 / 90$ & -0 & 0 & & $u$ & $\mathrm{pCi} / \mathrm{L}$ & & \\
\hline $299-W 27-1$ & Iron & $1 / 15 / 88$ & 106 & & & & $\mathrm{ppb}$ & & \\
\hline 299-W27-1 & Iron & $1 / 11 / 90$ & 177 & 21 & & & $\mathrm{ppb}$ & & \\
\hline 299-W27-1 & Iron. filtered & $3 / 09 / 87$ & 59 & & Y & & $\mathrm{ppb}$ & 20 & SW-846 6010 \\
\hline $299-W 27-1$ & Iron. filtered & $4 / 17 / 87$ & 50 & & Y & $u$ & $\mathrm{ppb}$ & 20 & SW-846 6010 \\
\hline $299-W 27-1$ & Iron. filtered & $7 / 24 / 87$ & 50 & & Y & u & $\mathrm{ppb}$ & 20 & SW-846 6010 \\
\hline 299-W27-1 & Iron. filtered & $10 / 15 / 87$ & 30 & & Y & u & $\mathrm{ppb}$ & 20 & SW-846 6010 \\
\hline 299-W27-1 & Iron. filtered & $1 / 15 / 88$ & 30 & & Y & u & $\mathrm{ppb}$ & 20 & SW-846 6010 \\
\hline 299-W27-1 & Iron. filtered & $8 / 18 / 88$ & 30 & & Y & u & $\mathrm{ppb}$ & 20 & SW-846 6010 \\
\hline
\end{tabular}









\begin{tabular}{|c|c|c|c|c|c|c|c|c|c|}
\hline Well & Constituent Name & Collect Date & Rerult & Error & filtered & Qualifier & Units & CRQL & Method Name \\
\hline$\cdots \ldots$ &  & $\ldots \ldots$ & $\cdots \cdots$ & $\cdots \cdots$ & & - & $\cdots$ & $\cdots$ & $\cdots$ \\
\hline $299 \cdot W 27-1$ & Lead. filtered & $10 / 15 / 87$ & 5 & & Y & U & $\mathrm{ppb}$ & 5 & SW-846 7421 \\
\hline $299 \cdot W 27-1$ & Lead. filtered & $1 / 15,88$ & 5 & & y & 11 & $\mathrm{ppb}$ & 5 & SW-846 7421 \\
\hline $299-W 27-1$ & Lead. filtered & $12 / 12 / 88$ & 5 & & $\gamma$ & 11 & $\mathrm{ppb}$ & 5 & SW-846 7421 \\
\hline $299 \cdot W_{27}-1$ & lead filtered & $1 / 11 / 90$ & 5 & 3 & r & U & $\mathrm{ppb}$ & 5 & SW-846 7421 \\
\hline $299 \cdot W 27-1$ & Lithium & $1 / 11 / 90$ & 10 & 2 & & U & $p p b$ & & \\
\hline $299-w 27-1$ & Lithrum & $1 / 11 / 90$ & 10 & 2 & y & 11 & $p p b$ & & SW-846 6010 \\
\hline 299-W27-1 & Lithium & $4 / 12 / 90$ & 10 & $\hat{\imath}$ & Y & 11 & $p p b$ & & SW-846 6010 \\
\hline $299-W 27-1$ & Lithium & $4: 12: 90$ & 10 & 2 & y & U & $p p b$ & & SW-846 6010 \\
\hline $299-W 27-1$ & Magnesium & $1 / 15 / 88$ & 13400 & & & & $p p b$ & & \\
\hline $299-W 27-1$ & Magnesium & $1 / 11 / 90$ & 1,3100 & 2130 & & & $\mathrm{ppb}$ & & \\
\hline $299-W 27-1$ & Magnesium. filtered & $309: 87$ & 15000 & & $r$ & & $\mathrm{ppb}$ & 100 & SW-846 6010 \\
\hline $299-W 27-1$ & Magnesium. filtered & $41 / 187$ & 1.4 .400 & & y & & ppb & 100 & SW-846 6010 \\
\hline $299 \cdot W 27-1$ & Magnesium. filtered & $724 / 87$ & 13700 & & $\gamma$ & & $p p b$ & 100 & SW-846 6010 \\
\hline $299-w 27-1$ & Magnesium. filtered & $10: 15: 87$ & 13700 & & r & & $\mathrm{ppb}$ & 100 & SW-846 6010 \\
\hline $299-W 27-1$ & Magnesium. filtered & $1 / 15 / 88$ & 1.3200 & & r & & ppb & 100 & SW-846 6010 \\
\hline $299 \cdot-w_{2} 7-1$ & Magnesium. filtered & $8 / 18 / 88$ & 12400 & & y & & $p p b$ & 100 & SW-846 6010 \\
\hline $299-W 27-1$ & Magnesium. filtered & $12 / 12 / 88$ & 12800 & & Y & & ppb & 100 & SW-846 6010 \\
\hline $299 \cdot W 27-1$ & Maqnesium. filtered & $111 / 90$ & 1.3400 & 2180 & Y & & ppb & 100 & SW-646 6010 \\
\hline $299-W 27-1$ & Magnesium. filtered & $4 / 12 / 90$ & 10100 & 1650 & y & & $\mathrm{ppb}$ & 100 & SW-846 6010 \\
\hline $299-W 27-1$ & Magnesium. filtered & $4 / 12 / 90$ & 9.390 & 15.30 & r & & $\mathrm{ppb}$ & 100 & SW-846 6010 \\
\hline $299-W 27-1$ & Magnesium. filtered & $2: 03: 92$ & 8100 & & Y & & $\mathrm{ppb}$ & 100 & SW-846 6010 \\
\hline $299-w 27-1$ & Magnesium. filtered & $3: 23: 92$ & 7500 & & Y & & ppb & 100 & SW-846 6010 \\
\hline $299-w_{2} 7-1$ & Magnesium. filtered & 70192 & 8000 & & y & & $\mathrm{ppb}$ & 100 & SW-846 6010 \\
\hline $299 \cdot w_{2} 7-1$ & Maqnesium. filtered & $10 \because 92$ & 8300 & & y & & $\mathrm{ppb}$ & 100 & SW-846 6010 \\
\hline $299 \cdot w_{2} 7-1$ & Magnesium. filtered & $12: 29: 92$ & 8300 & & Y & & ppb & 100 & SW-846 6010 \\
\hline $299 \cdot w 27 \cdot 1$ & Maanesium. filtered & 41293 & 2500 & .39 .10 & y & & $\mathrm{ppb}$ & 100 & SW-846 6010 \\
\hline $299 \cdot w 27-1$ & Maleic hydrazide & $115 \cdot 88$ & 500 & & & 11 & $\mathrm{ppb}$ & & \\
\hline $299+27-1$ & Maleic hydrazide & 11190 & 500 & 175 & & 11 & $\mathrm{ppb}$ & & \\
\hline
\end{tabular}




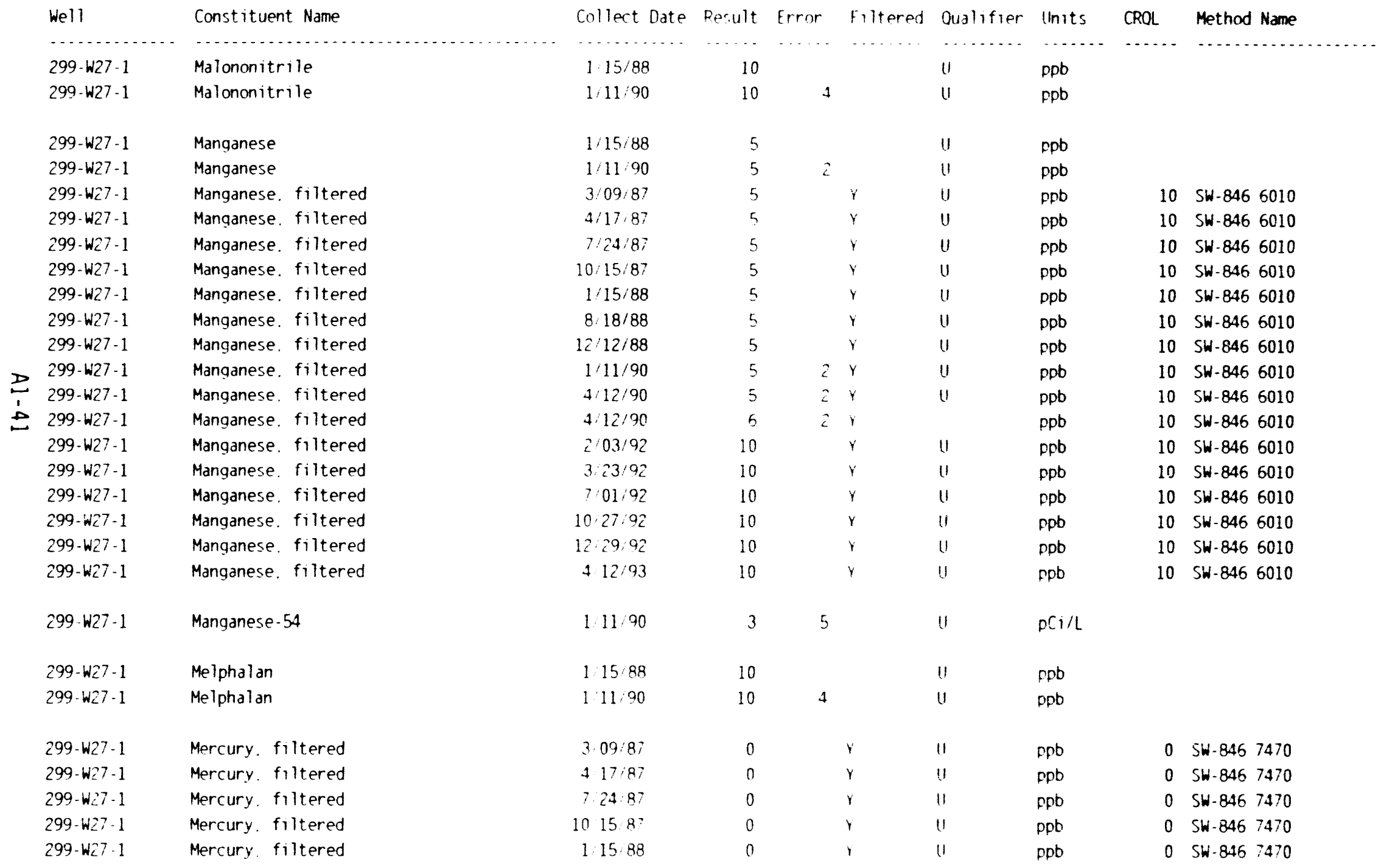




\begin{tabular}{|c|c|c|c|c|c|c|c|c|c|}
\hline Well & Constituent Name & Collect Date & Rerult & Error & Filtered & Qualifier & inits & CROL & Method Name \\
\hline $299 \cdot w 27 \cdot 1$ & Mercury. filtered & $1 / 11 / 00$ & 0 & 0 & $r$ & U & $\mathrm{ppb}$ & 0 & SW-846 7470 \\
\hline $299 \cdot W 27-1$ & Methacrylonitrile & $7 / 2487$ & 10 & & & 11 & $p p b$ & 5 & SW-846 8240 \\
\hline $299-W 27-1$ & Methacrylonitrile & $10 / 15,87$ & 10 & & & 4 & $p p b$ & 5 & SW-846 8240 \\
\hline $299-W 27-1$ & Methacryionitrile & $1 / 15 / 88$ & 10 & & & u & $\mathrm{ppb}$ & 5 & SW-846 8240 \\
\hline $299 \cdot W 27 \cdot 1$ & Methacrylonitrile & $8 / 18 / 88$ & 10 & & & 11 & $p p b$ & 5 & SW-846 8240 \\
\hline $299-W 27-1$ & Methacrylonitrile & $1: 11: 90$ & 10 & 4 & & 11 & $p p b$ & 5 & SW-846 8240 \\
\hline $290-W 27 \cdot 1$ & Methanethiol & $7 / 24 / 8$ & 10 & & & U & $p p b$ & & SH.846 8240 \\
\hline $299 \cdot W 27-1$ & Methanethiol & $10 / 158$ & 10 & & & U & $\mathrm{ppb}$ & & SH-846 8240 \\
\hline $299-W 27-1$ & Methanethrol & $1 / 15 / 88$ & 10 & & & U & $p p b$ & & $S W-8468240$ \\
\hline $299 \cdot W 27-1$ & Methanethiol & $818 / 88$ & 10 & & & U & $p p b$ & & SW-846 8240 \\
\hline $299-w 27 \cdot 1$ & Methanethiol & 11100 & 10 & 4 & & U & $\mathrm{ppb}$ & & SW-846 8240 \\
\hline $299-W 27-1$ & Methapyrilene & $1 / 1588$ & 10 & & & 4 & $\mathrm{ppb}$ & 10 & SW-846 8270 \\
\hline $299-W 27-1$ & Methapyrilene & $1 / 11: 90$ & 10 & 4 & & Ut & $\mathrm{ppb}$ & 10 & SW-846 8270 \\
\hline $299-W 27-1$ & Metholonyl & $1 / 15 / 88$ & 10 & & & 11 & $\mathrm{ppb}$ & & \\
\hline $299-W 27 \cdot 1$ & Metholonyl & $1: 11: 90$ & 10 & 4 & & 11 & $\mathrm{ppb}$ & & \\
\hline $299-W 27-1$ & Methoxychlor & $1 \cdot 1120$ & 3 & 1 & & u & $p p b$ & 2 & SW-846 8080 \\
\hline $299-W 27-1$ & Methyl lodide & $7: 24.8$ & 10 & & & 11 & $p p b$ & 5 & $5 W-8468240$ \\
\hline $299-W 27-1$ & Methyl Iodide & 10.1587 & 10 & & & 11 & $p p b$ & 5 & SW-846 8240 \\
\hline $299 \cdot W 27 \cdot 1$ & Methyl Iodide & $1: 15.88$ & 10 & & & 4 & $\mathrm{ppb}$ & 5 & $S W-8468240$ \\
\hline $299-W 27-1$ & Methyl Iodide & 81888 & 10 & & & 11 & $\mathrm{ppb}$ & 5 & SW-846 8240 \\
\hline $299-w 27-1$ & Methyl Iodide & $111: 00$ & 10 & 4 & & 4 & $p p b$ & 5 & SW-846 8240 \\
\hline $299-627-1$ & Methyl bromide & 728 & 10 & & & U & $p p b$ & 10 & SW-846 8240 \\
\hline $290 \cdot w 27-1$ & Methyl bromide & 10158 & 10 & & & 4 & $\mathrm{ppb}$ & 10 & SW-846 8240 \\
\hline $299 \cdot W 27-1$ & Methyl bromide & $1: 1588$ & 10 & & & "1 & $\mathrm{ppb}$ & 10 & SW-846 8240 \\
\hline $299 \cdot W 27-1$ & Methyl bromide & 818.88 & 10 & & & U1 & $\mathrm{ppb}$ & 10 & SW-846 8240 \\
\hline
\end{tabular}




\begin{tabular}{|c|c|c|c|c|c|c|c|c|c|}
\hline Well & Constituent Name & Collect Date & Result & Error & Filtered & Qualifier & Units & CRQL & Method Name \\
\hline$\ldots$ & 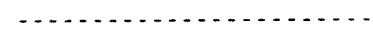 & $\ldots \ldots$ & $\cdots \cdots$ & $\cdots \cdots$ & $\cdots \cdots$ & $\ldots \ldots$ & $\cdots$ & $\ldots$. & $\cdots$ \\
\hline 299-W27-1 & Methyl bromide & $1 / 11 / 90$ & 10 & 4 & & $u$ & $\mathrm{ppb}$ & 10 & SW-846 8240 \\
\hline 299-W27-1 & Methyl chloride & $7 / 24 / 87$ & 10 & & & U & $\mathrm{ppb}$ & 10 & SW-846 8240 \\
\hline $299-W 27-1$ & Methyl chloride & $10 / 15 / 87$ & 10 & & & U & $\mathrm{ppb}$ & 10 & SW. 8468240 \\
\hline $299-W 27-1$ & Methyl chloride & $1 / 15 / 88$ & 10 & & & $U$ & $\mathrm{ppb}$ & 10 & SW- 8468240 \\
\hline $299-W 27-1$ & Methyl chloride & $8 / 18 / 88$ & 10 & & & $\mathrm{U}$ & $\mathrm{ppb}$ & 10 & SW-846 8240 \\
\hline $299-W 27-1$ & Methyl chloride & $1 / 11 / 90$ & 10 & 4 & & U & $p p b$ & 10 & SW-846 8240 \\
\hline $299-W 27-1$ & Methyl ethyl ketone & $3 / 09 / 87$ & 10 & & & U & $\mathrm{ppb}$ & 100 & SW-846 8240 \\
\hline 299-W27-1 & Methyl ethyl ketone & $4 / 17 / 87$ & 10 & & & $\mathrm{U}$ & $\mathrm{ppb}$ & 100 & SW-846 8240 \\
\hline $299 \cdot W 27-1$ & Methyl ethyl ketone & $7 / 24 / 87$ & 10 & & & u & $\mathrm{ppb}$ & 100 & SW-846 8240 \\
\hline $299-W 27-1$ & Methyl ethyl ketone & $10 / 15 / 87$ & 10 & & & $\mathrm{u}$ & $\mathrm{ppb}$ & 100 & SW-846 8240 \\
\hline 299-W27-1 & Methyl ethyl ketone & $1 / 15 / 88$ & 10 & & & u & $\mathrm{ppb}$ & 100 & SW-846 8240 \\
\hline $299-W 27-1$ & Methyl ethyl ketone & $8 / 18 / 88$ & 10 & & & U & $\mathrm{ppb}$ & 100 & SW-846 8240 \\
\hline $299-W 27-1$ & Methy 1 ethyl ketone & $12 / 12 / 88$ & 10 & & & U & $\mathrm{ppb}$ & 100 & SW-846 8240 \\
\hline $299-W 27-1$ & Methyl ethyl ketone & $1 / 11 / 90$ & 10 & 4 & & U & $\mathrm{ppb}$ & 100 & SW-846 8240 \\
\hline 299-W27-1 & Methyl ethyl ketone & $4 / 12 / 90$ & 10 & 4 & & U & $\mathrm{ppb}$ & 100 & SW-846 8240 \\
\hline $299-W 27-1$ & Methyl ethyl ketone & $2 / 03 / 92$ & 100 & & & u & $\mathrm{ppb}$ & 100 & SW-846 8240 \\
\hline 299-W27-1 & Methyl ethyl ketone & $3 / 23 / 92$ & 100 & & & U & $\mathrm{ppb}$ & 100 & SW-846 8240 \\
\hline 299-W27-1 & Methyl ethyl ketone & $7 / 01 / 92$ & 100 & & & 11 & $\mathrm{ppb}$ & 100 & SW-846 8240 \\
\hline $299-W 27-1$ & Methyl ethy1 ketone & $10 / 27 / 92$ & 100 & & & U & $\mathrm{ppb}$ & 100 & SW-846 8240 \\
\hline $299-W 27-1$ & Methyl ethyl ketone & $12 / 29 / 92$ & 100 & & & U & $\mathrm{ppb}$ & 100 & SW-846 8240 \\
\hline $299-W 27-1$ & Methyl ethyl ketone & $4 / 12 / 93$ & 100 & & & U & $\mathrm{ppb}$ & 100 & SW-846 8240 \\
\hline $299-W 27-1$ & Methyl methacrylate & $7 / 24 / 87$ & 10 & & & U & $\mathrm{ppb}$ & & \\
\hline 299-W27-1 & Methyl methacrylate & $10 / 15 / 87$ & 10 & & & U & $\mathrm{ppb}$ & & \\
\hline 299-W27-1 & Methyi methacrylate & $1 / 15 / 88$ & 10 & & & U & $\mathrm{ppb}$ & & \\
\hline 299-W27-1 & Methyl methacrylate & $8 / 18 / 88$ & 10 & & & U & $\mathrm{ppb}$ & & \\
\hline $299-W 27-1$ & Methyl methacrylate & $1 / 11 / 90$ & 10 & 4 & & u & $\mathrm{ppb}$ & & \\
\hline 299-W27-1 & Methyl methanesul fonate & $1 / 15 / 88$ & 10 & & & U & $\mathrm{ppb}$ & & \\
\hline 299-W27-1 & Methyl methanesulfonate & $1 / 11 / 90$ & 10 & 4 & & U & $\mathrm{ppb}$ & & \\
\hline
\end{tabular}


Well

Const ituent Name

Methyl parathion

Methylene chloride

Methylene chloride

Methylene chloride

Methylene chloride

Methylene chloride

Methylene chloride

Methylene chloride

Methylene chloride

Methylene chloride

Methylene chloride

Methylene chloride

Methylene chloride

Methylene chloride

Methylene chloride

Methylene chloride

299-W27

299-W27-1

$299-W 27-1$

299-W27-1

299-W27-1

$299-W 27-1$

$299-W 27-1$

299-w27-1

299-W27-I

299-W27-1

$299 \cdot w 27 \cdot 1$
Methylthiouracil

Methylthiouracil

Molybdenum

Molybdenum

Molybdenum

Molybdenum

Monobutyl Phosphate

N.N-Diethylhydrazine

N N-Diethylhydrazine

N.N-Diethylhydrazine
Collect Date Result Error Filtered Dualifier Units

................

\begin{tabular}{|c|c|c|c|c|}
\hline $1 / 11 / 90$ & 2 & 1 & & 11 \\
\hline $3 / 09 / 87$ & 10 & & & u \\
\hline $4 / 17 / 87$ & 10 & & & u \\
\hline $7 / 24 / 87$ & 10 & & & U \\
\hline $0 / 15 / 87$ & 10 & & & U \\
\hline $1 / 15 / 88$ & 10 & & & u \\
\hline $8 / 18 / 88$ & 10 & & & u \\
\hline $2 / 12 / 88$ & 10 & & & $u$ \\
\hline $1 / 11 / 90$ & 5 & 2 & & U \\
\hline $4 / 12 / 90$ & 5 & 2 & & u \\
\hline $2 / 03 / 92$ & 5 & & & u \\
\hline $3 / 23 / 92$ & 5 & & & U \\
\hline $7 / 01 / 92$ & 5 & & & U \\
\hline $10 / 27 / 92$ & 1 & & & UJ \\
\hline $2 / 29 / 92$ & 5 & & & u \\
\hline $4 / 12,93$ & 2 & & & BU \\
\hline $1 / 15 / 88$ & 10 & & & U \\
\hline $1 / 11 / 90$ & 10 & 4 & & U \\
\hline $1 / 11 / 90$ & 40 & 5 & & U \\
\hline $1 / 11 / 90$ & 40 & 5 & $\gamma$ & U \\
\hline $4 / 12 / 90$ & 40 & 5 & Y & U \\
\hline $4 / 12: 90$ & 40 & 5 & $Y$ & 0 \\
\hline $1 / 11 / 90$ & 10000 & 3500 & & u \\
\hline $7: 24: 87$ & 10 & & & U \\
\hline $0 / 15 / 87$ & 10 & & & u \\
\hline $1 / 15,88$ & 10 & & & u \\
\hline
\end{tabular}

SW-846 6010

SW-846 6010

SW-846 6010

SW-846 8240

SW- 8468240

SW- 8468240

SW-846 8240

SW-846 8240

SW-846 8240

Sh-846 8240

SW- 8468240

SW-846 8240

5 SW-846 8240

SW-846 8240

ppb

ppb 


\begin{tabular}{|c|c|c|c|c|c|c|c|c|c|}
\hline Well & Constituent Name & Collect Date & Recult & Error & Filtered & Qualifier & Units & CRQL & Method Name \\
\hline $299-W 27-1$ & N N-Diethylhydrazine & $8 / 18 / 88$ & 10 & $\ldots$ & ... & u & ppb & (n..... & SW-8468240 \\
\hline $299-w 27-1$ & N.N-Diethylhydrazine & $1 / 11 / 90$ & 10 & 4 & & u & $\mathrm{ppb}$ & & SW-846 8240 \\
\hline $299 \cdot W 27-1$ & $\mathrm{~N}$-Nitroso-N-methylurethane & $1 / 15 / 88$ & 10 & & & U & $\mathrm{ppb}$ & & \\
\hline $299-W 27-1$ & $\mathrm{~N}$-Nitroso-N-methylurethane & $1 / 11 / 90$ & 10 & 4 & & U & $\mathrm{ppb}$ & & \\
\hline $299-W 27-1$ & N-Nitroso-di-n-dipropylamine & $1 / 15 / 88$ & 10 & & & 11 & $\mathrm{ppb}$ & & \\
\hline 299-W27-1 & N-Nitroso-di-n-dipropyl amine & $1 / 11 / 90$ & 10 & 4 & & U & $\mathrm{ppb}$ & & \\
\hline $299-W 27-1$ & $N$-Nitrosodi-n-butylamine & $1 / 15 / 88$ & 10 & & & U & $\mathrm{ppb}$ & & \\
\hline 299-W27-1 & $\mathrm{N}$-Nitrosodi-n-butylamine & $1 / 11 / 90$ & 10 & 4 & & U & $\mathrm{ppb}$ & & \\
\hline $299-w 27-1$ & N. Nitrosodiethanol amine & $1 / 15 / 88$ & 10 & & & U & $\mathrm{ppb}$ & & \\
\hline $299-W 27-1$ & $\mathrm{~N}$-Nitrosodiethanolamine & $1 / 11 / 90$ & 10 & 4 & & U & $\mathrm{ppb}$ & & \\
\hline $299-W 27-1$ & N-Nitrosodiethyl amine & $1 / 15 / 88$ & 10 & & & U & $\mathrm{ppb}$ & & \\
\hline $299-W 27-1$ & N-Nitrosodiethylamine & $1 / 11 / 90$ & 10 & 4 & & U & $\mathrm{ppb}$ & & \\
\hline $299-W 27-1$ & $\mathrm{~N}$-Nitrosodimethylamine & $1 / 15 / 88$ & 10 & & & U & $\mathrm{ppb}$ & & \\
\hline $299-W 27-1$ & $\mathrm{~N}$-Nitrosodimethylamine & $1 / 11 / 90$ & 10 & 4 & & U & ppt: & & \\
\hline $299-W 27-1$ & $\mathrm{~N}$-Nitrosodiphenylamine & $1 / 11 / 90$ & 10 & 4 & & U & $\mathrm{ppb}$ & & \\
\hline $299-W 27-1$ & N-Nitrosomethylethylamine & $1 / 15 / 88$ & 10 & & & U & $\mathrm{ppb}$ & & \\
\hline $299-W 27-1$ & N-Nitrosomethylethylamine & $1 / 11 / 90$ & 10 & 4 & & U & ppb & & \\
\hline $299-W 27-1$ & N-Nitrosomethylvinylamine & $1 / 15 / 88$ & 10 & & & U & ppb & & \\
\hline $299-W 27-1$ & $\mathrm{~N}$-Nitrosomethylvinylamine & $1 / 11 / 90$ & 10 & 4 & & U & $\mathrm{ppb}$ & & \\
\hline 299-W27-1 & N-Nitrosomorphol ine & $1 / 15 / 88$ & 10 & & & U & ppb & & \\
\hline $299-W 27-1$ & $\mathrm{~N}$-Nitrosomorphol ine & $1 / 11 / 90$ & 10 & 4 & & U & $\mathrm{ppb}$ & & \\
\hline $299-W 27-1$ & N-Nitrosonornicotine & $1 / 15 / 88$ & 10 & & & U & $\mathrm{ppb}$ & & \\
\hline $299-W 27-1$ & $\mathrm{~N}$-Nitrosonornicotine & $1 / 11 / 90$ & 10 & 4 & & U & $\mathrm{ppb}$ & & \\
\hline
\end{tabular}




\begin{tabular}{|c|c|c|c|c|c|c|c|c|c|}
\hline Well & Constituent Name & Collect Date & Result & Error & Filtered & Qualifier & Units & CRQL & Method Name \\
\hline$\ldots$ & - & $\ldots$ & - - - - & $\ldots$. & & $\cdots$ & 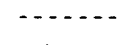 & & $\cdots$ \\
\hline 299-W27-1 & N-Nitrosopiperidine & $1 / 15 / 88$ & 10 & & & U & $\mathrm{ppb}$ & & \\
\hline $299-W 27-1$ & N-Nitrosopiperidine & $1 / 11 / 90$ & 10 & 4 & & U & $\mathrm{ppb}$ & & \\
\hline $299-W 27-1$ & N-Phenylthiourea & $1 / 11 / 90$ & 500 & 150 & & U & $\mathrm{ppb}$ & & \\
\hline $299-W 27-1$ & N-Propylamine & $1 / 11 / 90$ & 10000 & 3500 & & U & $\mathrm{ppb}$ & & \\
\hline 299-W27-1 & Naphthalene & $7 / 24 / 87$ & 10 & & & U & $\mathrm{ppb}$ & & \\
\hline 299-W27-1 & Naphthalene & $10 / 15 / 87$ & 10 & & & U & $\mathrm{ppb}$ & & \\
\hline $299-W 27-1$ & Naphthalene & $1 / 15 / 88$ & 10 & & & $u$ & ppb & & \\
\hline 299-W27-1 & Naphthalene & $1 / 11 / 90$ & 10 & 4 & & U & $\mathrm{ppb}$ & & \\
\hline 299-W27-1 & Nickel & $1 / 15 / 88$ & 10 & & & U & $\mathrm{ppb}$ & & \\
\hline $299-W 27-1$ & Nickel & $1 / 11 / 90$ & 10 & 3 & & $U$ & $\mathrm{ppb}$ & & \\
\hline 299-W27-1 & Nickel. filtered & $3 / 09 / 87$ & 10 & & $\gamma$ & U & $\mathrm{ppb}$ & 30 & SW-846 6010 \\
\hline 299-W27-1 & Nickel. filtered & $4 / 17 / 87$ & 10 & & $Y$ & U & $\mathrm{ppb}$ & 30 & SW-846 6010 \\
\hline $299-W 27-1$ & Nickel. filtered & $7 / 24 / 87$ & 10 & & Y & (1) & $\mathrm{ppb}$ & 30 & SW-846 6010 \\
\hline 299-W27-1 & Nickel. filtered & $10 / 15 / 87$ & 10 & & Y & U & $\mathrm{ppb}$ & 30 & SW-846 6010 \\
\hline 299-W27-1 & Nickel. filtered & $1 / 15 / 88$ & 10 & & Y & $U$ & $\mathrm{ppb}$ & 30 & SW-846 6010 \\
\hline 299-W27-1 & Nickel. filtered & $8 / 18 / 88$ & 10 & & Y & U & $\mathrm{ppb}$ & 30 & SW-846 6010 \\
\hline 299-W27-1 & Nickel, filtered & $12 / 12 / 88$ & 10 & & Y & U & $\mathrm{ppb}$ & 30 & SW-846 6010 \\
\hline 299-W27-1 & Nickel. filtered & $1 / 11 / 90$ & 10 & 3 & Y & U & $\mathrm{ppb}$ & 30 & SW-846 6010 \\
\hline 299-W27-1 & Nickel. filtered & $4 / 12 / 90$ & 10 & 3 & Y & U & $\mathrm{ppb}$ & 30 & SW-846 6010 \\
\hline $299-W 27-1$ & Nickel. filtered & $4 / 12 / 90$ & 10 & 3 & Y & U & $\mathrm{ppb}$ & 30 & SW-846 6010 \\
\hline $299-W 27-1$ & Nickel. filtered & $2 / 03 / 92$ & 30 & & Y & U & ppo & 30 & SW-846 6010 \\
\hline $299-W 27-1$ & Nickel. filtered & $3 / 23 / 92$ & 30 & & Y & $U$ & $\mathrm{ppb}$ & 30 & SW-846 $6 C 10$ \\
\hline $299-W 27-1$ & Nickel. filtered & $7 / 01 / 92$ & 30 & & $Y$ & U & $\mathrm{ppb}$ & 30 & SW-846 6010 \\
\hline 299-W27-1 & Nickel. filtered & $10 / 27 / 92$ & 30 & & Y & U & $\mathrm{ppb}$ & 30 & SW-846 6010 \\
\hline 299-W27-1 & Nickel. filtered & $12 / 29 / 92$ & 30 & & Y & U & $\mathrm{ppb}$ & 30 & SW-846 6010 \\
\hline 299-W27-1 & Nickel. filtered & $4 / 12 / 93$ & 30 & & Y & U & $\mathrm{ppb}$ & 30 & SW-846 6010 \\
\hline $299-w 27-1$ & Nicotinic acid & $1 / 15 / 88$ & 100 & & & U & $\mathrm{ppb}$ & & \\
\hline
\end{tabular}


11/08/93 Groundwater Well Results for 299-W27-1 Page 46

\begin{tabular}{|c|c|c|c|c|c|c|c|c|c|}
\hline Well & Constituent Name & Collect Date & Result & Error & Filtered & Qualifier & Units & CRQL & Method Name \\
\hline (n. & n & $\ldots$ & - . - - & - . . & $\ldots$ & $\ldots \ldots$ & $\cdots$ & $\cdots$ & $\cdots$ \\
\hline $299-W 27-1$ & Nicotinic acid & $1 / 11 / 90$ & 100 & 35 & & U & $\mathrm{ppb}$ & & \\
\hline 299-W27-1 & Nitrate & $7 / 18 / 84$ & 4 & & & & $\mathrm{ppm}$ & & \\
\hline $299-W 27-1$ & Nitrate & $8 / 06 / 84$ & 5 & & & & ppm & & \\
\hline 299-W27-1 & Nitrate & $10 / 09 / 84$ & 17 & & & & ppm & & \\
\hline $299-W 27-1$ & Nitrate & $11 / 05 / 84$ & 23 & & & & ppm & & \\
\hline $299-W 27-1$ & Nitrate & $12 / 06 / 84$ & 23 & & & & $\mathrm{ppm}$ & & \\
\hline $299-W 27-1$ & Nitrate & $1 / 08 / 85$ & 23 & & & & $\mathrm{ppm}$ & & \\
\hline $299-W 27-1$ & Nitrate & $4 / 15 / 85$ & 27 & & & & $\mathrm{ppm}$ & & \\
\hline 299-W27-1 & Nitrate & $7 / 11 / 85$ & 26 & 5 & & & $\mathrm{ppm}$ & & \\
\hline 299-W27-1 & Nitrate & $12 / 20 / 85$ & 96 & 18 & & & ppm & & \\
\hline $299-W 27-1$ & Nitrate & $1 / 07 / 86$ & 118 & 22 & & & $\mathrm{ppm}$ & & \\
\hline 299-W27-1 & Nitrate & $4 / 07 / 86$ & 116 & 22 & & & ppm & & \\
\hline $299-W 27-1$ & Nitrate & $7 / 02 / 86$ & 93 & 17 & & & $\mathrm{ppm}$ & & \\
\hline 299-W27-1 & Nitrate & $11 / 25 / 86$ & 87200 & & & & $\mathrm{ppb}$ & & EPA 300.0 \\
\hline 299-W27-1 & Nitrate & $1 / 20 / 87$ & 113000 & & & & $\mathrm{ppb}$ & & EPA 300.0 \\
\hline 299-W27-1 & Nitrate & $3 / 09 / 87$ & 128000 & & & & $\mathrm{ppb}$ & & EPA 300.0 \\
\hline $299-W 27-1$ & Nitrate & $4 / 17 / 87$ & 118000 & & & & $\mathrm{ppb}$ & & EPA 300.0 \\
\hline 299-W27-1 & Nitrate & $4 / 17 / 87$ & 118000 & & & & $\mathrm{ppb}$ & & EPA 300.0 \\
\hline 299-W27-1 & Nitrate & $7 / 24 / 87$ & 108000 & & & & $\mathrm{ppb}$ & & EPA 300.0 \\
\hline 299-W27-1 & Nitrate & $7 / 24 / 87$ & 110000 & & & & $\mathrm{ppb}$ & & EPA 300.0 \\
\hline 299-W27-1 & Nitrate & $10 / 12 / 87$ & 78200 & & & & $\mathrm{ppb}$ & & EPA 300.0 \\
\hline 299-W27-1 & Nitrate & $10 / 15 / 87$ & 82600 & & & & $\mathrm{ppb}$ & & EPA 300.0 \\
\hline 299-W27-1 & Nitrate & $1 / 15 / 88$ & 60000 & & & & ppb & & EPA 300.0 \\
\hline 299-W27-1 & Nitrate & $1 / 15 / 88$ & 61100 & & & & $\mathrm{ppb}$ & & EPA 300.0 \\
\hline 299-W27-1 & Nitrate & $5 / 16 / 88$ & 49300 & & & & $\mathrm{ppb}$ & & EPA 300.0 \\
\hline 299-W27-1 & Nitrate & $8 / 18 / 88$ & 29000 & & & & $\mathrm{ppb}$ & & EPA 300.0 \\
\hline 299-W27-1 & Nitrate & $8 / 18 / 88$ & 28200 & & & & $\mathrm{ppb}$ & & EPA 300.0 \\
\hline $299-W 27-1$ & Nitrate & $12 / 12 / 88$ & 63500 & & & & $\mathrm{ppb}$ & & EPA 300.0 \\
\hline 299-W27-1 & Nitrate & $12 / 15 / 88$ & 34400 & & & & $\mathrm{ppb}$ & & EPA 300.0 \\
\hline 299-W27-1 & Nitrate & $2 / 01 / 89$ & 96900 & 9700 & & & $\mathrm{ppb}$ & & EPA 300.0 \\
\hline 299-W27-1 & Nitrate & $1 / 11 / 90$ & 70500 & 7100 & & & $\mathrm{ppb}$ & & EPA 300.0 \\
\hline
\end{tabular}




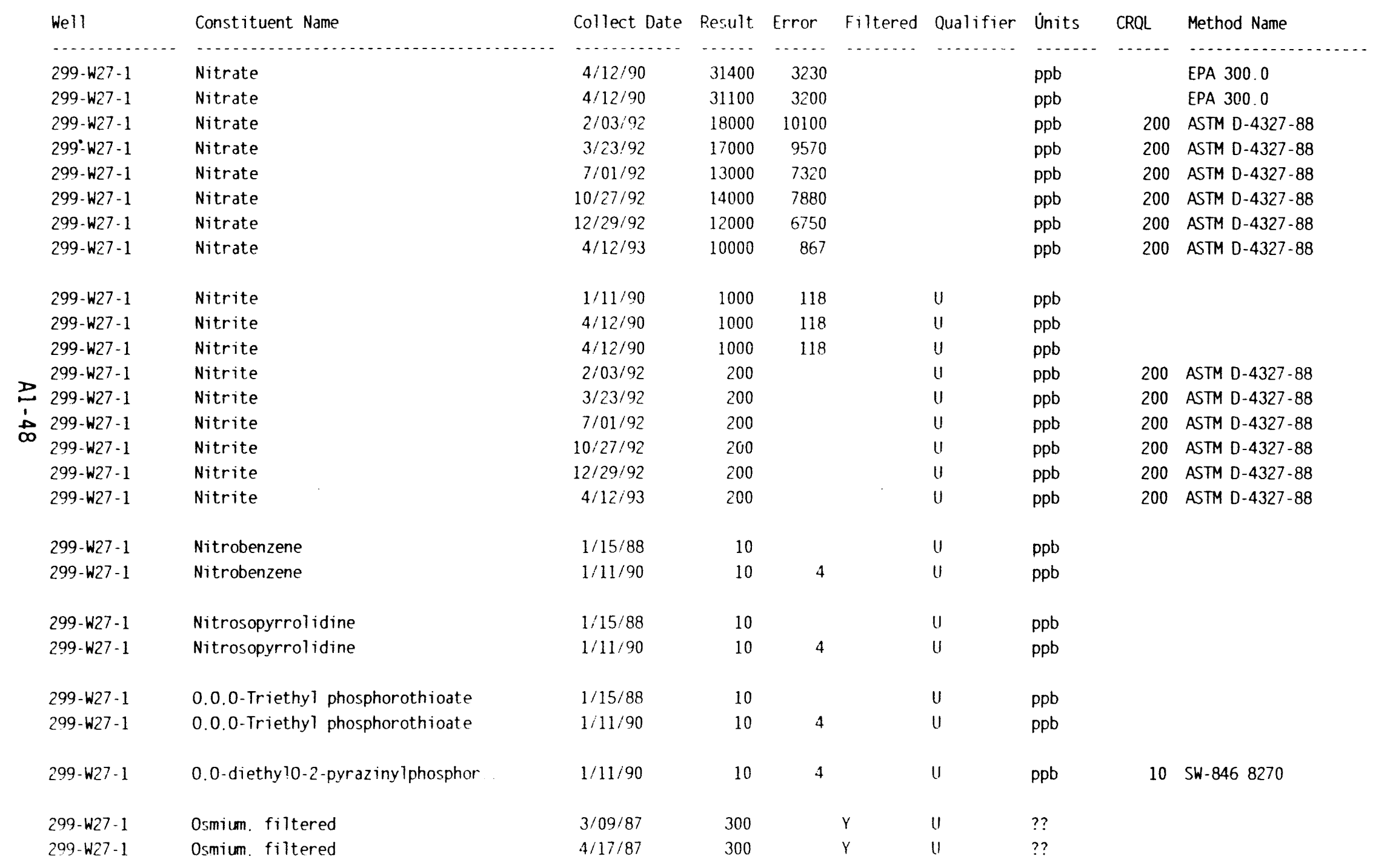




\begin{tabular}{|c|c|c|c|c|c|c|c|c|c|}
\hline Well & Constituent Name & Collect Date & Result & Error & Filtered & Qualifier & Units & CRQL & Method Name \\
\hline  & ' & -.......... & -.... & $\ldots .$. & $\ldots . . .-$ & .......... & $-\ldots$ & 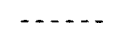 & $\cdots+\cdots$ \\
\hline $299-W 27-1$ & Osmium. filtered & $7 / 24 / 87$ & 300 & & Y & U & ?? & & \\
\hline $299-W 27-1$ & PCODs & $1 / 11 / 90$ & 0 & 0 & & $\mathrm{U}$ & $\mathrm{ppb}$ & 0 & SW-846 8280 \\
\hline $299-W 27-1$ & PCDFs & $1 / 11 / 90$ & 0 & 0 & & U & $\mathrm{ppb}$ & 0 & SW-846 8280 \\
\hline $299-W 27-1$ & Paraldehyde & $1 / 11 / 90$ & 10000 & 3500 & & U & $\mathrm{ppb}$ & & \\
\hline $299-W 27-1$ & Parathion & $1 / 11 / 90$ & 2 & 1 & & U & $\mathrm{ppb}$ & & SW-846 8140 \\
\hline $299-W 27-1$ & Pentachlorobenzene & $7 / 24 / 87$ & 10 & & & $U$ & $\mathrm{ppb}$ & & \\
\hline 299-W27-1 & Pentachlorobenzene & $10 / 15 / 87$ & 10 & & & U & $\mathrm{ppb}$ & & \\
\hline $299-W 27-1$ & Pentachlorobenzene & $1 / 15 / 88$ & 10 & & & $\mathrm{U}$ & $\mathrm{ppb}$ & & \\
\hline 299-W27-1 & Pentachlorobenzene & $1 / 11 / 90$ & 10 & 4 & & U & $\mathrm{ppb}$ & & \\
\hline $299-W 27-1$ & Pentachirroethane & $7 / 24 / 87$ & 10 & & & U & $\mathrm{ppb}$ & 5 & SW-846 8240 \\
\hline 299-W27-1 & Pentachioroethane & $10 / 15 / 87$ & 10 & & & U & $\mathrm{ppb}$ & 5 & SW-846 8240 \\
\hline $299-W 27-1$ & Pentachloroethane & $1 / 15 / 88$ & 10 & & & U & $\mathrm{ppb}$ & 5 & SW-846 8240 \\
\hline $299-W 27-1$ & Pentachloroethane & $8 / 18 / 88$ & 10 & & & U & $\mathrm{ppb}$ & 5 & SW- 8468240 \\
\hline $299-W 27-1$ & Pentachloroethane & $1 / 11 / 90$ & 10 & 4 & & U & $\mathrm{ppb}$ & 5 & SW-846 8240 \\
\hline 299-W27-1 & Pentachloronitrobenzene (PCNB) & $1 / 15 / 88$ & 10 & & & U & $\mathrm{ppb}$ & & \\
\hline $299-W 27-1$ & Pentachloronitrobenzene (PCNB) & $1 / 11 / 90$ & 10 & 4 & & U & $\mathrm{ppb}$ & & \\
\hline $299-W 27-1$ & Pentachlorophenol & $1 / 15 / 88$ & 50 & & & U & $\mathrm{ppb}$ & & \\
\hline $299-W 27-1$ & Pentachlorophenol & $1 / 11 / 90$ & 50 & 18 & & U & $\mathrm{ppb}$ & & \\
\hline $299-W 27-1$ & Perchlorate & $1 / 11 / 90$ & 500 & 52 & & U & $\mathrm{ppb}$ & & EPA 300.0 \\
\hline 299-W27-1 & Phenacetin & $1 / 15 / 88$ & 10 & & & U & $\mathrm{ppb}$ & & \\
\hline $299-W 27-1$ & Phenacetin & $1 / 11 / 90$ & 10 & 4 & & $U$ & $\mathrm{ppb}$ & & \\
\hline $299-W 27-1$ & Phenanthrene & $1 / 11 / 90$ & 10 & 4 & & U & $\mathrm{ppb}$ & & \\
\hline
\end{tabular}


11/08/93 Groundwater Well Results for 299-W27-1 Page 49

\begin{tabular}{|c|c|c|c|c|c|c|c|c|c|}
\hline Well & Constituent Name & Collect Date & Result & Error & Filtered & Qualifier & Units & CRQL & Method Name \\
\hline - n & ( non & $\ldots \ldots$ & $\cdots \cdots$ & $\cdots$ & n...... & $\cdots \cdots$ & ...... & - . . & - n \\
\hline 299-W27-1 & Phenol & $7 / 24 / 87$ & 10 & & & i & $\mathrm{ppb}$ & & \\
\hline $299-W 27-1$ & Phenol & $10 / 15 / 87$ & 10 & & & $U$ & $\mathrm{ppb}$ & & \\
\hline 299-W27-1 & Phenol & $1 / 15 / 88$ & 10 & & & U & $\mathrm{ppb}$ & & \\
\hline $299-W 27-1$ & Phenol & $1 / 11 / 90$ & 10 & 4 & & U & $\mathrm{ppb}$ & & \\
\hline 299-W27-1 & Phenylenedi amine & $1 / 15 / 88$ & 10 & & & U & $\mathrm{ppb}$ & & \\
\hline $299-W 27-1$ & Phenylenedi amine & $1 / 11 / 90$ & 10 & 4 & & U & $\mathrm{ppb}$ & & \\
\hline $299-W 27-1$ & Phorate & $1 / 11 / 90$ & 2 & 1 & & U & $\mathrm{ppb}$ & 2 & SW-846 8140 \\
\hline 299-W27-1 & Phosphate & $3 / 09 / 87$ & 1000 & & & U & $\mathrm{ppb}$ & & EPA 300.0 \\
\hline $299-W 27-1$ & Phosphate & $4 / 17 / 87$ & 1000 & & & U & $\mathrm{ppb}$ & & EPA 300.0 \\
\hline 299-W27-1 & Phosphate & $7 / 24 / 87$ & 1000 & & & U & $\mathrm{ppb}$ & & EPA 300.0 \\
\hline S 299-W27-1 & Phosphate & $10 / 15 / 87$ & 1000 & & & U & $\mathrm{ppb}$ & & EPA 300.0 \\
\hline $299-W 27-1$ & Phosphate & $1 / 15 / 88$ & 1000 & & & U & $\mathrm{ppb}$ & & EPA 300.0 \\
\hline $299-W 27-1$ & Phosphate & $8 / 18 / 88$ & 1000 & & & U & $\mathrm{ppb}$ & & EPA 300.0 \\
\hline 299-W27-1 & Phosphate & $12 / 12 / 88$ & 1000 & & & U & $\mathrm{ppb}$ & & EPA 300.0 \\
\hline 299-W27-1 & Phosphate & $1 / 11 / 90$ & 1000 & 141 & & U & $\mathrm{ppb}$ & & EPA 300.0 \\
\hline 299-W27-1 & Phosphate & $4 / 12 / 90$ & 1000 & 141 & & U & $\mathrm{ppb}$ & & EPA 300.0 \\
\hline 299-W27-1 & Phosphate & $4 / 12 / 90$ & 1000 & 141 & & U & $\mathrm{ppb}$ & & EPA 300.0 \\
\hline 299-W27-1 & Phosphate & $2 / 03 / 92$ & 400 & & & U & $\mathrm{ppb}$ & 400 & ASTM D-4327-88 \\
\hline 299-W27-1 & Phosphate & $2 / 03 / 92$ & 400 & & & U & $\mathrm{ppb}$ & 500 & ASTM D-4327-88 \\
\hline 299-W27-1 & Phosphate & $3 / 23 / 92$ & 400 & & & U & $\mathrm{ppb}$ & 400 & ASTM D-4327-88 \\
\hline 299-W27-1 & Phosphate & $3 / 23 / 92$ & 400 & & & U & $\mathrm{ppb}$ & 500 & ASTM D-4327-88 \\
\hline 299-W27-1 & Phosphate & 7/01/92 & 400 & & & U & $\mathrm{ppb}$ & 400 & ASTM D-4327-88 \\
\hline $299-W 27-1$ & Phosphate & 7/01/92 & 400 & & & U & $\mathrm{ppb}$ & 500 & ASTM D-4327-88 \\
\hline 299-W27-1 & Phosphate & $10 / 27 / 92$ & 400 & & & U & $\mathrm{ppb}$ & 400 & ASTM D-4327-88 \\
\hline 299-W27-1 & Phosphate & $10 / 27 / 92$ & 400 & & & U & $\mathrm{ppb}$ & 500 & ASTM D-4327-88 \\
\hline 299-W27-1 & Phosphate & $12 / 29 / 92$ & 400 & & & u & $\mathrm{ppb}$ & 400 & ASTM D-4327-88 \\
\hline $299-W 27-1$ & Phosphate & $12 / 29 / 92$ & 400 & & & U & $\mathrm{ppb}$ & 500 & ASTM D-4327-88 \\
\hline $299-W 27-1$ & Phosphate & $4 / 12 / 93$ & 400 & & & U & $\mathrm{ppb}$ & 400 & ASTM D-4327-88 \\
\hline
\end{tabular}




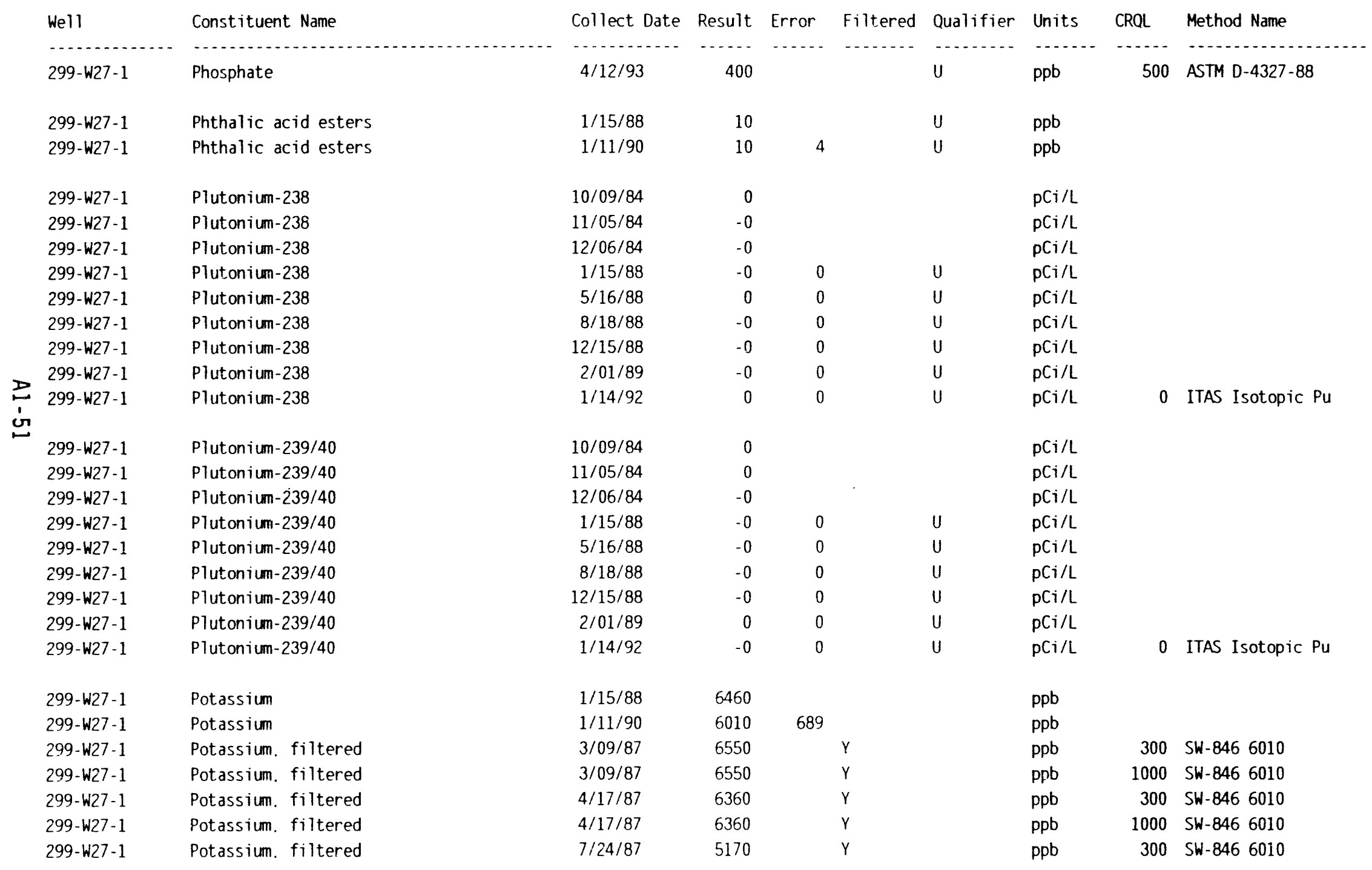









\begin{tabular}{|c|c|c|c|c|c|c|c|c|c|}
\hline Well & Constituent Name & Collect Date & Result & Error & Filtered & Qualifier & Units & CRQL & Method Name \\
\hline$\ldots \ldots$ & . & $\cdots$ & - . . - & - . . & ....... & & $\cdots$ & $\cdots$ & $\cdots$ \\
\hline 299-W27-1 & Pyrene & $1 / 11 / 90$ & 10 & 4 & & U & $\mathrm{ppb}$ & & \\
\hline $299-W 27-1$ & Pyridine & $7 / 24 / 87$ & 500 & & & U & $\mathrm{ppb}$ & 5 & SW-846 8240 \\
\hline $299-W 27-1$ & Pyridine & $10 / 15 / 87$ & 500 & & & $u$ & $\mathrm{ppb}$ & 5 & SW-846 8240 \\
\hline $299-W 27-1$ & Pyridine & $1 / 15 / 88$ & 500 & & & U & $\mathrm{ppb}$ & 5 & SW-846 8240 \\
\hline $299-W 27-1$ & Pyridine & $8 / 18 / 88$ & 500 & & & U & $\mathrm{ppb}$ & 5 & SW-846 8240 \\
\hline $299-W 27-1$ & Pyridine & $1 / 11 / 90$ & 500 & 175 & & U & $\mathrm{ppb}$ & 5 & SW-846 8240 \\
\hline $299-627-1$ & Radium & $3 / 09 / 87$ & -0 & 0 & & U & $\mathrm{pCi} / \mathrm{L}$ & & \\
\hline $299-W 27-1$ & Radium & $4 / 17 / 87$ & 0 & 0 & & & $\mathrm{pCi} / \mathrm{L}$ & & \\
\hline $299-W 27-1$ & Radium & $1 / 15 / 88$ & 0 & 0 & & U & $\mathrm{pCi} / \mathrm{L}$ & & \\
\hline $299-W 27-1$ & Radium & $1 / 11 / 90$ & 0 & 0 & & U & $\mathrm{pCi} / \mathrm{L}$ & & \\
\hline $299-W 27-1$ & Reserpine & $1 / 15 / 88$ & 10 & & & U & $\mathrm{ppb}$ & & \\
\hline $299-W 27-1$ & Reserpine & $1 / 11 / 90$ & 10 & 4 & & U & $\mathrm{ppb}$ & & \\
\hline $299-W 27-1$ & Resorcinol & $1 / 15 / 88$ & 10 & & & U & $\mathrm{ppb}$ & & \\
\hline $239-W 27-1$ & Resorcinol & $1 / 11 / 90$ & 10 & 4 & & U & $\mathrm{ppb}$ & & \\
\hline $299-W 27-1$ & Ruthenium-106 & $10 / 09 / 84$ & -9 & & & & $\mathrm{pCi} / \mathrm{L}$ & & \\
\hline $299-W 27-1$ & Ruthenium-106 & $11 / 05 / 84$ & 58 & & & & $\mathrm{pCi} / \mathrm{L}$ & & \\
\hline $299-W 27-1$ & Ruthenium-106 & $12 / 06 / 84$ & -12 & & & & $\mathrm{pCi} / \mathrm{L}$ & & \\
\hline $299-W 27-1$ & Ruthenium-106 & $1 / 08 / 85$ & 14 & & & & $\mathrm{pCi} / \mathrm{L}$ & & \\
\hline $299-W 27-1$ & Ruthenium-106 & $4 / 15 / 85$ & 69 & & & & $\mathrm{pCi} / \mathrm{L}$ & & \\
\hline $299-W 27-1$ & Ruthenium-106 & $7 / 11 / 85$ & 14 & 40 & & U & $\mathrm{pCi} / \mathrm{L}$ & & \\
\hline 299-W27-1 & Ruthenium-106 & $10 / 08 / 85$ & 47 & 34 & & & $\mathrm{pCi} / \mathrm{L}$ & & \\
\hline 299-W27-1 & Ruthenium-106 & $1 / 07 / 86$ & -53 & 61 & & U & $\mathrm{pCi} / \mathrm{L}$ & & \\
\hline $299-W 27-1$ & Ruthenium-106 & $4 / 07 / 86$ & -20 & 56 & & U & $\mathrm{pCi} / \mathrm{L}$ & & \\
\hline $299-W 27-1$ & Ruthenium-106 & $7 / 02 / 86$ & 11 & 54 & & U & $\mathrm{pCi} / \mathrm{L}$ & & \\
\hline $299-W 27-1$ & Ruthenium-106 & $11 / 25 / 86$ & -44 & 81 & & U & $\mathrm{pCi} / \mathrm{L}$ & & \\
\hline $299-W 27-1$ & Ruthenium-106 & $1 / 20 / 87$ & -11 & 48 & & U & $\mathrm{pCi} / \mathrm{L}$ & & \\
\hline
\end{tabular}


Well 299-W27-1 299-W27-1 299-W27-1 299- $w 27-1$ 299-W27-1 299-W27-1 299-W27-1 299-W27-1 299-W27-1 299-W27-1 299-W27-1 299-W27-1 299-W27-1 D 299-W27-1 in

299-W27-1

299-W27-i

299-W27-1

299-W27-1

299-W27-1

299-W27-1

299-W27-1

299-W27-1

299- $-127-1$

299-W27-1

299-W27-1

299-W27-1

299-W27-1

299-W27-1

299-W27-1

$299-w_{2} 7 \cdot 1$
Constituent Name

Ruthenium-106

Ruthenium-106

Ruthenium-106

Ruthenium-106

Ruthenium-106

Ruthenium-106

Ruthenium-106

Ruthenium-106

Ruthenium-106

Ruthenium-106

Ruthenium-106

Ruthenium-106

Ruthenium-106

Ruthenium-106

Safrol

Safrol

Selenium

Selenium

Selenium

Selenium

Selenium

Selenium

Selenium. filtered

Selenium. filtered

Selenium. filtered

Selenium. filtered

Selenium. filtered

Selenium. filtered

Selenium. filtered

selenium. filtered
Collect Date Result Error Filtered Qualifier Units

CRQL Method Name

$\begin{array}{rr}4 / 17 / 87 & 15 \\ 7 / 23 / 87 & 102 \\ 10 / 12 / 87 & 22 \\ 1 / 15 / 88 & 19 \\ 5 / 16 / 88 & -6 \\ 8 / 18 / 88 & 13 \\ 12 / 15 / 88 & -18 \\ 2 / 01 / 89 & 8 \\ 1 / 11 / 90 & 41 \\ 3 / 23 / 92 & -50 \\ 10 / 27 / 92 & -1 \\ 12 / 29 / 92 & -24 \\ 4 / 12 / 93 & -12 \\ 7 / 20 / 93 & -6 \\ & \\ 1 / 15 / 88 & 10 \\ 1 / 11 / 90 & 10 \\ 1 / 15 / 88 & \\ 1 / 11 / 90 & 21 \\ 3 / 23 / 92 & 35 \\ 10 / 27 / 92 & 10 \\ 4 / 12 / 93 & 10 \\ 7 / 20 / 93 & 10 \\ 3 / 09 / 87 & 3 \\ 4 / 17 / 87 & 54 \\ 7 / 24 / 87 & 54 \\ 10 / 15 / 87 & 46 \\ 1 / 15 / 88 & 24 \\ 1 / 11 / 90 & 33 \\ 3 / 23 / 92 & 10 \\ 10 / 27 / 92 & 10 \\ & \end{array}$

40
51
71
59
39
63
46
70
40

U

$\mathrm{pCi} / \mathrm{L}$

$\mathrm{pCi} / \mathrm{L}$

$\mathrm{pCi} / \mathrm{L}$

$\mathrm{pCi} / \mathrm{L}$

$\mathrm{pCi} / \mathrm{L}$

$\mathrm{pCi} / \mathrm{L}$

$\mathrm{pCi} / \mathrm{L}$

$\mathrm{pCi} / \mathrm{L}$

$\mathrm{pCi} / \mathrm{L}$

$\mathrm{pCi} / \mathrm{L}$

$\mathrm{pCi} / \mathrm{L}$

$\mathrm{pCi} / \mathrm{L}$

$\mathrm{pCi} / \mathrm{L}$

$\mathrm{pCi} / \mathrm{L}$

ITAS Garma Scan

ITAS Gamma Scan

ITAS Gamma Scan

ITAS Gamma Scan

ITAS Gamma Scan

$\mathrm{ppb}$

$p p b$

ppb

$p p b$

$\mathrm{ppb}$

ppb

$\mathrm{ppb}$

$\mathrm{ppb}$

$\mathrm{ppb}$

$\mathrm{ppb}$

ppb

ppb

$p p b$

ppb

ppb

$p p b$
10 SW-846 7740
$10 \mathrm{SW}-8467740$
10 SW-846 7740
10 SW-846 7740
10 SW-846 7740
10 SW-846 7740
10 SW-846 7740
10 SW-846 7740
10 SW- 8467740
10 SW-846 7740
10 SW-846 7740
10 SW- 8467740 


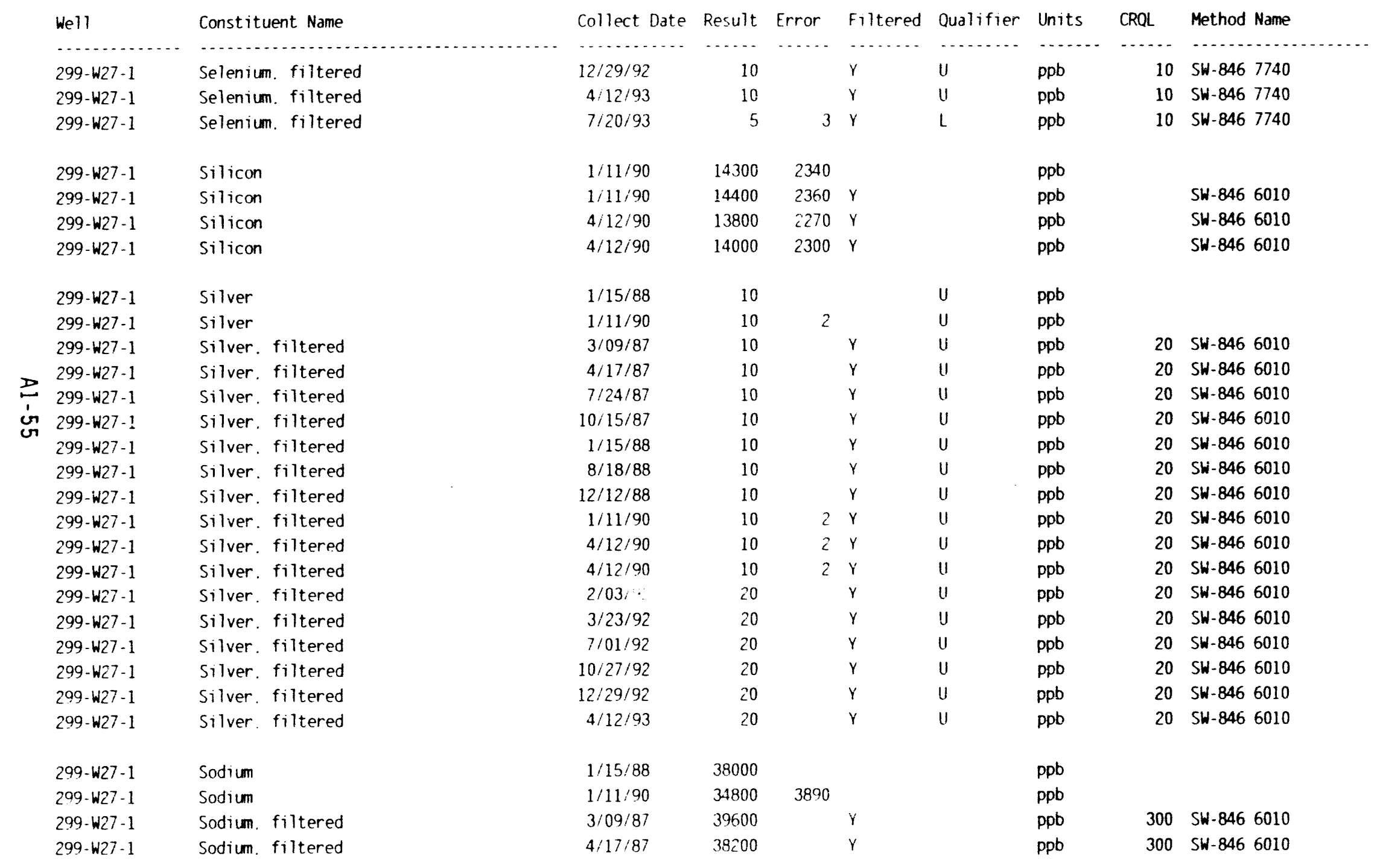




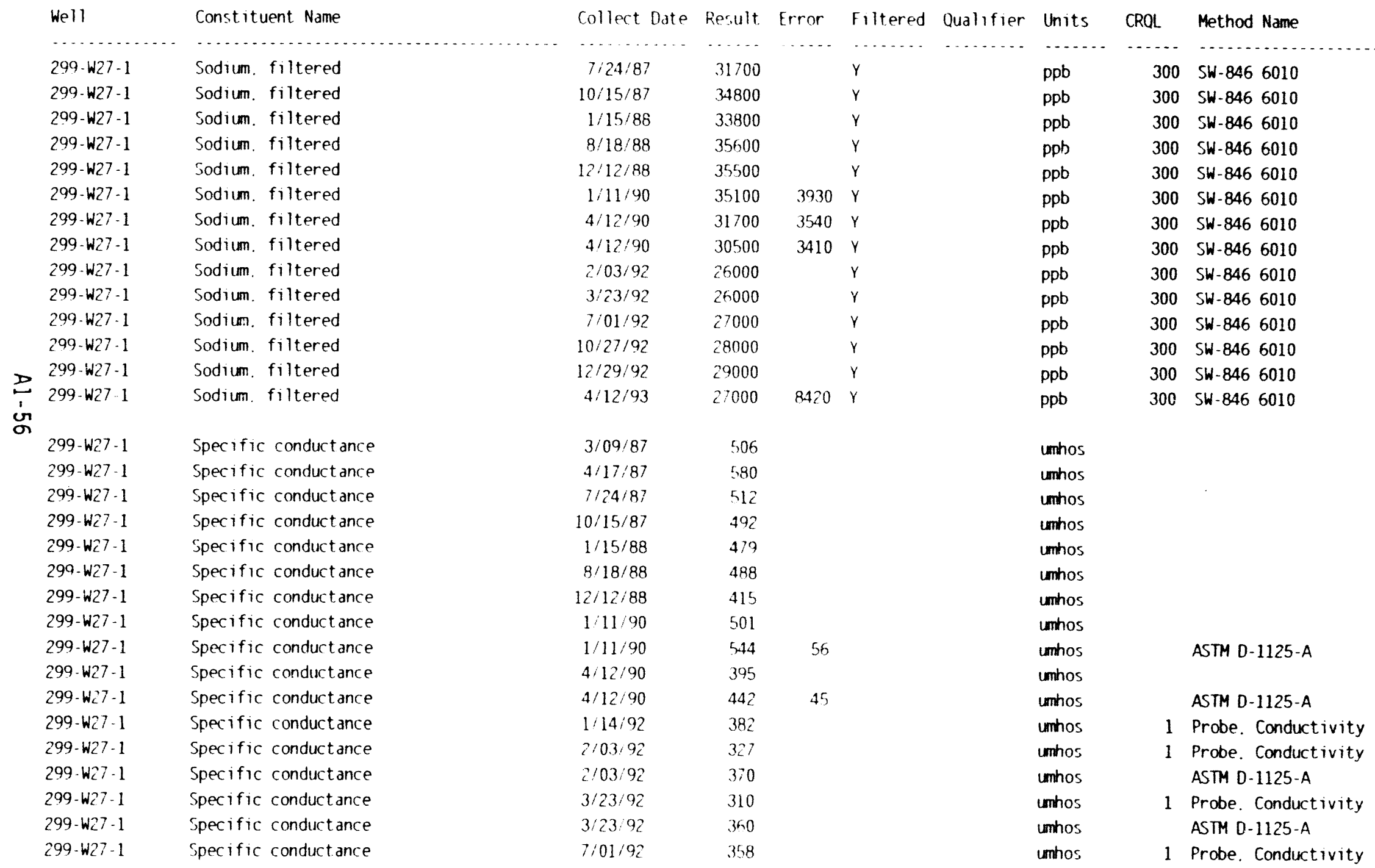









\begin{tabular}{|c|c|c|c|c|c|c|c|c|c|}
\hline Well & Constituent Name & Collec: Date & Result & Error & Filtered & Qualifier & Units & CRQL & Method Name \\
\hline (n) & (1) & - n & …… & - . . - & $\cdots \cdots$ & ...... & - . . & $\cdots$ & $\cdots$ \\
\hline $299-W 27-1$ & Strontium-90 & $7 / 12 / 86$ & 0 & 1 & & U & $\mathrm{pCi} / \mathrm{L}$ & & \\
\hline $299-W 27-1$ & Strontium-90 & $11 / 25 / 86$ & 0 & 1 & & U & $\mathrm{pCi} / \mathrm{L}$ & & \\
\hline $299-W 27-1$ & Strontium-90 & $1 / 20 / 87$ & 1 & 1 & & U & $\mathrm{pCi} / \mathrm{L}$ & & \\
\hline $299^{\circ}-W 27-1$ & Stront ium-90 & $4 / 17 / 87$ & 0 & 1 & & U & $\mathrm{pCi} / \mathrm{L}$ & & \\
\hline 299-W27-1 & Strontium-90 & $7 / 23 / 87$ & 0 & 1 & & U & $\mathrm{pCi} / \mathrm{L}$ & & \\
\hline 299-W27-1 & Stront ium-90 & $10 / 12 / 87$ & -0 & 1 & & U & $\mathrm{pCi} / \mathrm{L}$ & & \\
\hline $299-W 27-1$ & Strontium-90 & $1 / 15 / 88$ & 1 & 1 & & & $\mathrm{pCi} / \mathrm{L}$ & & \\
\hline 299-W27-1 & Strontium-90 & $5 / 16 / 88$ & -0 & 1 & & U & $\mathrm{pCi} / \mathrm{L}$ & & \\
\hline $299-W 27-1$ & Strontium-90 & $8 / 18 / 88$ & -0 & 1 & & U & $\mathrm{pCi} / \mathrm{L}$ & & \\
\hline 299-W27-1 & Strontium-90 & $12 / 15 / 88$ & -0 & 1 & & 1 & $\mathrm{pCi} / \mathrm{L}$ & & \\
\hline 299-W27-1 & Stront ium-90 & $2 / 01 / 89$ & -1 & 1 & & U & $\mathrm{pCi} / \mathrm{L}$ & & \\
\hline 299-W27-1 & Stront ium-90 & $1 / 11 / 90$ & 0 & 1 & & U & $\mathrm{pCi} / \mathrm{L}$ & & \\
\hline 299-W27-1 & Stront ium-90 & $3 / 23 / 92$ & -0 & 1 & & U & $\mathrm{pCi} / \mathrm{L}$ & 5 & ITAS $\mathrm{Sr}-90$ \\
\hline 299-W27-1 & Strontium-90 & $10 / 27 / 92$ & -0 & 0 & & U & $\mathrm{pCi} / \mathrm{L}$ & 5 & ITAS $\mathrm{Sr}-90$ \\
\hline 299-W27-1 & Strontium-90 & $12 / 29 / 92$ & -0 & 0 & & U & $\mathrm{pCi} / \mathrm{L}$ & 5 & ITAS Sr-90 \\
\hline 299-W27-1 & Stront ium-90 & $4 / 12 / 93$ & -1 & 0 & & U & $\mathrm{pCi} / \mathrm{L}$ & 5 & ITAS Sr-90 \\
\hline $299-W 27-1$ & Strontium-90 & $7 / 20 / 93$ & -0 & 0 & & u & $\mathrm{pCi} / \mathrm{L}$ & 5 & ITAS Sr-90 \\
\hline $299 \cdot W 27-1$ & Strychnine & $1 / 15 / 88$ & 50 & & & U & $\mathrm{ppb}$ & & \\
\hline $299-W 27-1$ & Strychnine & $1 / 11 / 90$ & 50 & 18 & & U & $\mathrm{ppb}$ & & \\
\hline 299-W27-1 & Styrene & $1 / 11 / 90$ & 5 & 2 & & $u$ & $\mathrm{ppb}$ & 5 & SW-846 8240 \\
\hline $299-W 27-1$ & Sulfate & $3 / 09 / 87$ & 61600 & & & & $\mathrm{ppb}$ & & EPA 300.0 \\
\hline $299-W 27-1$ & Sulfate & $4 / 17 / 87$ & 10900 & & & & $\mathrm{ppb}$ & & EPA 300.0 \\
\hline 299-W27-1 & Sulfate & $7 / 24 / 87$ & 63500 & & & & $\mathrm{ppb}$ & & EPA 300.0 \\
\hline $299-W 27-1$ & Sulfate & $10 / 15 / 87$ & 62500 & & & & $\mathrm{ppb}$ & & EPA 300.0 \\
\hline 299-W27-1 & Sulfate & $1 / 15 / 88$ & 53100 & & & & $\mathrm{ppb}$ & & EPA 300.0 \\
\hline 299-W27-1 & Sulfate & $8 / 18 / 88$ & 39300 & & & & $\mathrm{ppb}$ & & EPA 300.0 \\
\hline 299-W27-1 & Sulfate & $12 / 12 / 88$ & 43600 & & & & $\mathrm{ppb}$ & & EPA 3000 \\
\hline $299-W 27-1$ & Sulfate & $1 / 11 / 90$ & 58700 & 5910 & & & $\mathrm{ppb}$ & & EPA 300.0 \\
\hline $299-W 27-1$ & Sulfate & $4 / 12 / 90$ & 36600 & 3710 & & & $\mathrm{ppb}$ & & EPA 300.0 \\
\hline
\end{tabular}




\begin{tabular}{|c|c|c|c|c|c|c|c|c|c|}
\hline Well & Constituent Name & Collect Date & Result & Error & Filtered & Qualifier & Units & CRQL & Method Name \\
\hline . & - & $\ldots \ldots$ & $\ldots$ & $\ldots \ldots$ & $\ldots \ldots$ & $\cdots$ & $\ldots$ & $\cdots$ & \\
\hline 299-W27-1 & Sulfate & $4 / 12 / 90$ & 36100 & .3660 & & & ppb & & EPA 300.0 \\
\hline $299-W 27-1$ & Sulfate & $2 / 03 / 92$ & 30000 & 28900 & & & $\mathrm{ppb}$ & 500 & ASTM $0-4327-88$ \\
\hline 299-W27-1 & Sulfate & $3 / 23 / 92$ & 28000 & 27000 & & & $\mathrm{ppb}$ & 500 & ASTM D-4327-88 \\
\hline 299-W27-1 & Sulfate & $7 / 01 / 92$ & 27000 & 26000 & & & $\mathrm{ppb}$ & 500 & ASTM D-4327-88 \\
\hline $299-W 27-1$ & Sulfate & $10 / 27 / 92$ & 26000 & 25100 & & & $\mathrm{ppb}$ & 500 & ASTM $0-4327-88$ \\
\hline 299-W27-1 & Sulfate & $12 / 29 / 92$ & 25000 & 24100 & & & ppb & 500 & ASTM D-4327-88 \\
\hline $299-W 27-1$ & Sulfate & $4 / 12 / 93$ & 24000 & 1170 & & & $\mathrm{ppb}$ & 500 & ASTM $0-4327-88$ \\
\hline 299-W27-1 & Sulfide & $1 / 11 / 90$ & 1000 & 208 & & u & $\mathrm{ppb}$ & 10000 & SW-8469030 \\
\hline 299-W27-1 & Technet ium-99 & $1 / 11 / 90$ & 3 & 6 & & u & $\mathrm{pCi} / \mathrm{L}$ & & \\
\hline $299-W 27-1$ & Temperature. field & $3 / 0937$ & 19 & & & & DegC & 0 & Probe. temperature \\
\hline $299-W 27-1$ & Temperature. field & $4 / 17 / 87$ & 20 & & & & DegC & 0 & Probe. temperature \\
\hline 299-W27-1 & Temperature. field & $7 / 24 / 87$ & 16 & & & & Deạc & 0 & Probe. temperature \\
\hline 299-W27-1 & Temperature. field & $10 / 15 / 87$ & 19 & & & & DegC & 0 & Probe. temperature \\
\hline $299-W 27-1$ & Temperature. field & $12 / 12$ & 19 & & & & $\operatorname{Deg} C$ & 0 & Probe. temperature \\
\hline 299-W27-1 & Temperature. field & $1 / 11$ & 20 & & & & DegC & 0 & Probe. temperature \\
\hline $299-W 27-1$ & Tenpili iture. field & $4 / 12$ & 19 & & & & $\operatorname{DegC}$ & 0 & Probe. temperature \\
\hline 299-W27-1 & Temper ature. field & $1 / 14 / 92$ & 19 & & & & DegC & 0 & Probe. temperature \\
\hline $299-W 27-1$ & Temperature. field & $2 / 03 / 92$ & 20 & & & & DegC & 0 & Probe. temperature \\
\hline 299-W27-1 & Temperature. field & $3 / 23 / 92$ & 19 & & & & DegC & 0 & Probe. temperature \\
\hline $299-W 27-1$ & Temperature. field & $7 / 01 / 92$ & 20 & & & & DegC & 0 & Probe. temperature \\
\hline $299-W 27-1$ & Temperature. field & $10 / 27 / 92$ & 19 & & & & DegC & 0 & Probe. temperature \\
\hline $299 \cdot W 27-1$ & Temperature. field & $12 / 29 / 92$ & 19 & & & & $\operatorname{DegC}$ & 0 & Probe. temperature \\
\hline 299-W27-1 & Temperature. field & $4 / 12 / 93$ & 20 & & & & DegC & 0 & Probe. temperature \\
\hline 299-W27-1 & Temperature. field & $7 / 20 / 93$ & 20 & & & & DegC & 0 & Probe. temperature \\
\hline $299-W 27-1$ & Tetrachloroethene & $3 / 09 / 87$ & 10 & & & U & $\mathrm{ppb}$ & 5 & F., \\
\hline $299-W 27-1$ & Tetrachloroethene & $4 / 17 / 87$ & 10 & & & U & $\mathrm{ppb}$ & & $W-3240$ \\
\hline $299 \cdot W 27-1$ & Tetrachloroethene & $7 / 24 / 87$ & 10 & & & U & $\mathrm{ppb}$ & $\therefore$ & 8240 \\
\hline
\end{tabular}


Wel

299-W27-1

299-W27-1

299-W27-1

299-W27-1

299-W27-1

299-W27-1

299-W27-1

299-W27-1

299-W27-1

299-W27-1

299-W27-1

299-W27-1

D 299-W27-1

o

299-W27-1

299-W27-1

299-W27-1

299-W27-1

299-W27-1

299-W27-1

299-W27-1

299-W27-1

299-W27-1

299-W27-1

299-W27-1

299-W27-1

299-W27-1
Constituent Name

Tetrachloroethene

Tetrachloroethene

Tetrachloroethene

Tetrachloroethene

Tetrachloroethene

Tetrachloroethene

Tetrachloroethene

Tetrachloroethene

Tetrachloroethene

Tetrachloroethene

Tetrachloroethene

Tetrachloroethene

Tetraethylpyrophosphate

Tetrahydrofuran

Tetrahydrofuran

Tetrahydrofuran

Tetrahydrofuran

Tetrahydrofuran

Tetrahydrofuran

Tetrahydrofuran

Tetrahydrofuran

Thallium

Thallium. filtered

Thiofanox

Thiofanox

Thiourea
Collect Date Result Error Filtered Qualifier Units

$$
\begin{array}{r}
10 / 15 / 87 \\
1 / 15 / 88 \\
8 / 18 / 88 \\
12 / 12 / 88 \\
1 / 11 / 90 \\
4 / 12 / 90 \\
2 / 03 / 92 \\
3 / 23 / 92 \\
7 / 01 / 92 \\
10 / 27 / 92 \\
12 / 29 / 92 \\
4 / 12 / 93
\end{array}
$$

$1 / 11 / 90$

$1 / 11 / 90$

$4 / 12 / 90$

2/03/92

$3 / 23 / 92$

7/01/92

$10 / 27 / 92$

$12 / 29 / 92$

$4 / 12 / 93$

$1 / 11 / 90$

$1 / 11 / 90$

$1 / 15 / 88$

$1 / 11 / 90$

$1 / 11 / 90$



$\begin{array}{ll}U & \mathrm{ppb} \\ U & \mathrm{ppb} \\ U & \mathrm{ppb} \\ U & \mathrm{ppb} \\ U & \mathrm{ppb} \\ U & \mathrm{ppb} \\ U & \mathrm{ppb} \\ U & \mathrm{ppb} \\ U & \mathrm{ppb} \\ U & \mathrm{ppb} \\ U & \mathrm{ppb} \\ U & \mathrm{ppb} \\ U & \mathrm{ppb} \\ U & \mathrm{ppb} \\ U & \mathrm{ppb} \\ U & \mathrm{ppb} \\ U & \mathrm{ppb} \\ U & \mathrm{ppb} \\ U & \mathrm{ppb} \\ U & \mathrm{ppb} \\ U & \mathrm{ppb} \\ U & \mathrm{ppb} \\ U & \mathrm{ppb} \\ U & \\ U & \\ U & \\ U & \\ U & \\ U & \\ U & \\ U & \\ U & \\ U & \end{array}$

CRQL Method Name

5 SH-846 8240

5 SW-846 8240

5 SW-846 8240

5 SW-8.6 8240

5 SW-846 8240

5 SW-846 824i

5 SW-846 8240

5 SW-846 8240

5 SW-846 8240

5 SW-846 8240

5 SW-846 8240

5 SW-846 8240

SW-846 8140

10 SW-846 8240

10 SW-846 8240

10 SW-846 8240

10 SW-846 8240

10 SW-846 8240

10 SW-846 8240

10 SW-846 8240

10 SW-846 8240

5 SW-846 7841 


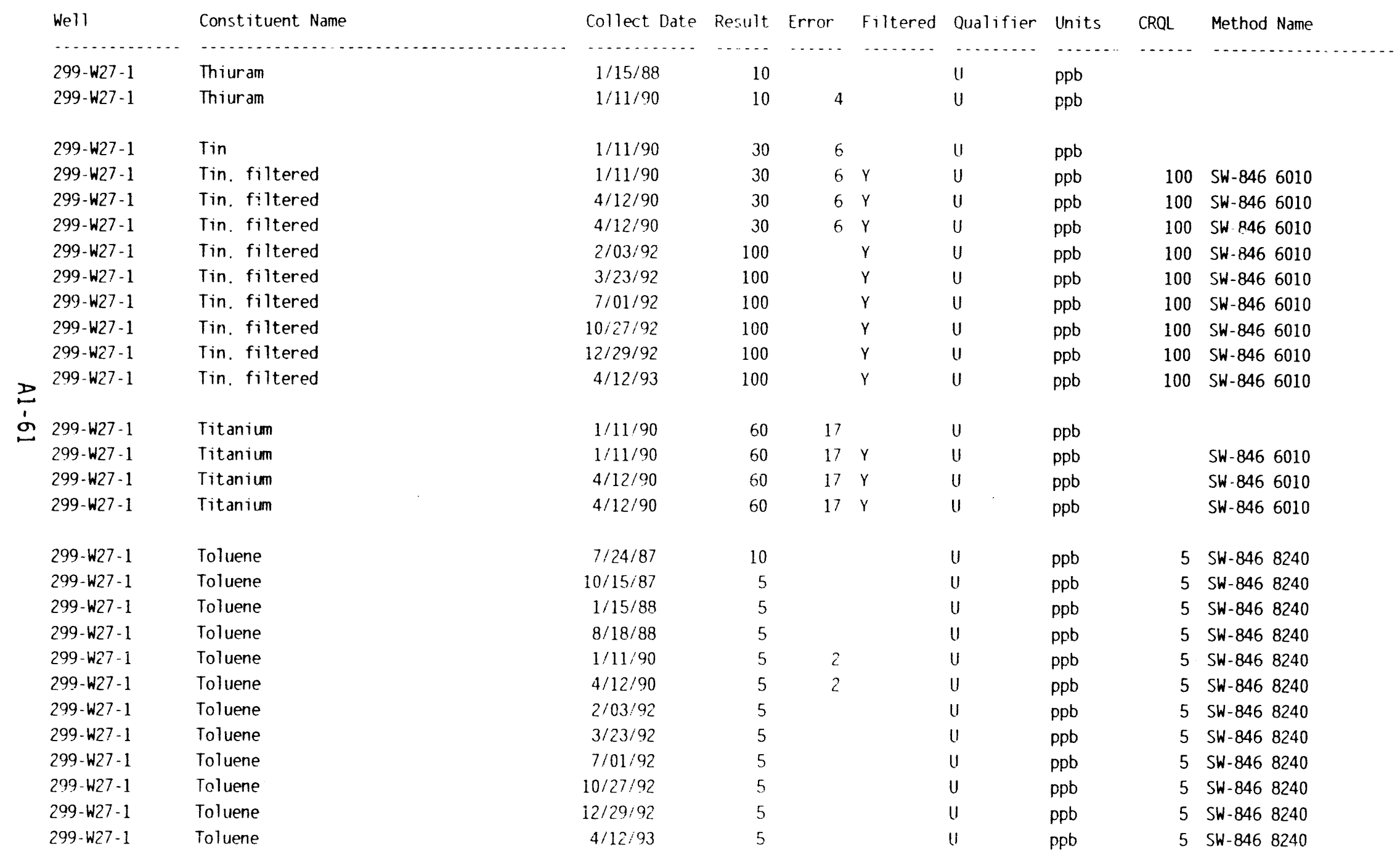




\begin{tabular}{|c|c|c|c|c|c|c|c|c|c|c|}
\hline Well & Constituent Name & Collect Date & Result & Error & Filtered & Qualifier & Units & CRQL & Method & Name \\
\hline$\ldots$ & (n) & $\ldots$ & $\cdots$ & $\cdots \cdots$ & $\ldots$ & $\cdots \cdots$ & $\ldots \ldots$ & $\cdots$ & & \\
\hline 299-W27-1 & Toluenedi amine & $1 / 15 / 88$ & 10 & & & U & $\mathrm{ppb}$ & & & \\
\hline 299-W27-1 & Toluenedi amine & $1 / 11 / 90$ & 10 & 4 & & $U$ & $\mathrm{ppb}$ & & & \\
\hline $299-W 27-1$ & Total Carbon & $7 / 24 / 87$ & 29100 & & & & $\mathrm{ppb}$ & 2000 & ASTM D & D-2579-A \\
\hline 299-W27-1 & Total Carbon & $10 / 15 / 87$ & 31600 & & & & $\mathrm{ppb}$ & 2000 & ASTM D & D-2579-A \\
\hline $299-W 27-1$ & Total Carbon & $1 / 15 / 88$ & 32900 & & & & $\mathrm{ppb}$ & 2000 & ASTM D & D-2579-A \\
\hline 299-W27-1 & Total Carbon & $8 / 18 / 88$ & 33400 & & & & $\mathrm{ppb}$ & 2000 & ASTM D & D-2579-A \\
\hline 299-W27-1 & Total Carbon & $12 / 12 / 88$ & 32600 & & & & $\mathrm{ppb}$ & 2000 & ASTM D & $D-2579-A$ \\
\hline $299-W 27-1$ & Total Carbon & $1 / 11 / 90$ & 32200 & 3460 & & & $\mathrm{ppb}$ & 2000 & ASTM D & D.2579-A \\
\hline 299-W27-1 & Total Organic Carbon & $3 / 09 / 87$ & 229 & & & $\mathrm{U}$ & $\mathrm{ppb}$ & & & \\
\hline 299-W27-1 & Total Organic Carbon & $4 / 17 / 87$ & 349 & & & U & $\mathrm{ppb}$ & & & \\
\hline 299-W27-1 & Total Organic Carbon & $7 / 24 / 87$ & 3850 & & & & $\mathrm{ppb}$ & & & \\
\hline 299-W27-1 & Total Organic Carbon & $10 / 15 / 87$ & 449 & & & U & $\mathrm{ppb}$ & & & \\
\hline 299-W27-1 & Total Organic Carbon & $1 / 15 / 88$ & 352 & & & $u$ & $\mathrm{ppb}$ & & & \\
\hline 299-W27-1 & Total Organic Carbon & $8 / 18 / 88$ & 717 & & & U & $\mathrm{ppb}$ & & & \\
\hline $299-W 27-1$ & Total Organic Carbon & $12 / 12 / 88$ & 300 & & & $\mathrm{U}$ & $\mathrm{ppb}$ & & & \\
\hline $299-W 27-1$ & Total Organic Carbon & $1 / 11 / 90$ & 400 & 56 & & U & $\mathrm{ppb}$ & & & \\
\hline 299-W27-1 & Total Organic Carbon & $2 / 03 / 92$ & 1000 & & & U & $\mathrm{ppb}$ & 1000 & SW-846 & 9060 \\
\hline 299-W27-1 & Total Organic Carbon & $3 / 23 / 92$ & 1000 & & & u & $\mathrm{ppb}$ & 1000 & SW-846 & 59060 \\
\hline $299-W 27-1$ & Total Organic Carbon & $7 / 01 / 92$ & 1000 & & & U & $\mathrm{ppb}$ & 1000 & SW-846 & 69060 \\
\hline 299-W27-1 & Total Organic Carbon & $10 / 27 / 92$ & 1000 & & & U & $\mathrm{ppb}$ & 1000 & SW-846 & 59060 \\
\hline $299-W 27-1$ & Total Organic Carbon & $12 / 29 / 92$ & 1000 & & & U & $\mathrm{ppb}$ & 1000 & SW-846 & 59060 \\
\hline $299-W 27-1$ & Total Organic Carbon & $4 / 12 / 93$ & 1000 & & & U & $\mathrm{ppb}$ & 1000 & SW-846 & 59060 \\
\hline $299-W 27-1$ & Total Organic Carbon & $7 / 20 / 93$ & 300 & & & $\mathrm{~L}$ & $\mathrm{ppb}$ & 1000 & SW-846 & 59060 \\
\hline 299-W27-1 & Tutal Organic Halogen & $3 / 09 / 87$ & 20 & & & U & $\mathrm{ppb}$ & 10 & SW-846 & 59020 \\
\hline 299-W27-1 & Total Organic Halogen & $4 / 17 / 87$ & 20 & & & U & $\mathrm{ppb}$ & 10 & SW-846 & 69020 \\
\hline 299-W27-1 & Total Organic Halogen & $7 / 24 / 87$ & 6 & & & U & $\mathrm{ppb}$ & 10 & SW-846 & 69020 \\
\hline $299-W 27-1$ & Total Organic Halogen & $10 / 15 / 87$ & 11 & & & 11 & $\mathrm{ppb}$ & 10 & SW-846 & 59020 \\
\hline 299-W27-1 & Total Organic Halogen & $1 / 15 / 88$ & 13 & & & u & $\mathrm{ppb}$ & 10 & SW-846 & 69020 \\
\hline $299-W 27-1$ & Total Organic Halogen & $1 / 11 / 90$ & 10 & 4 & & & $\mathrm{ppb}$ & 10 & SW-846 & 59020 \\
\hline
\end{tabular}




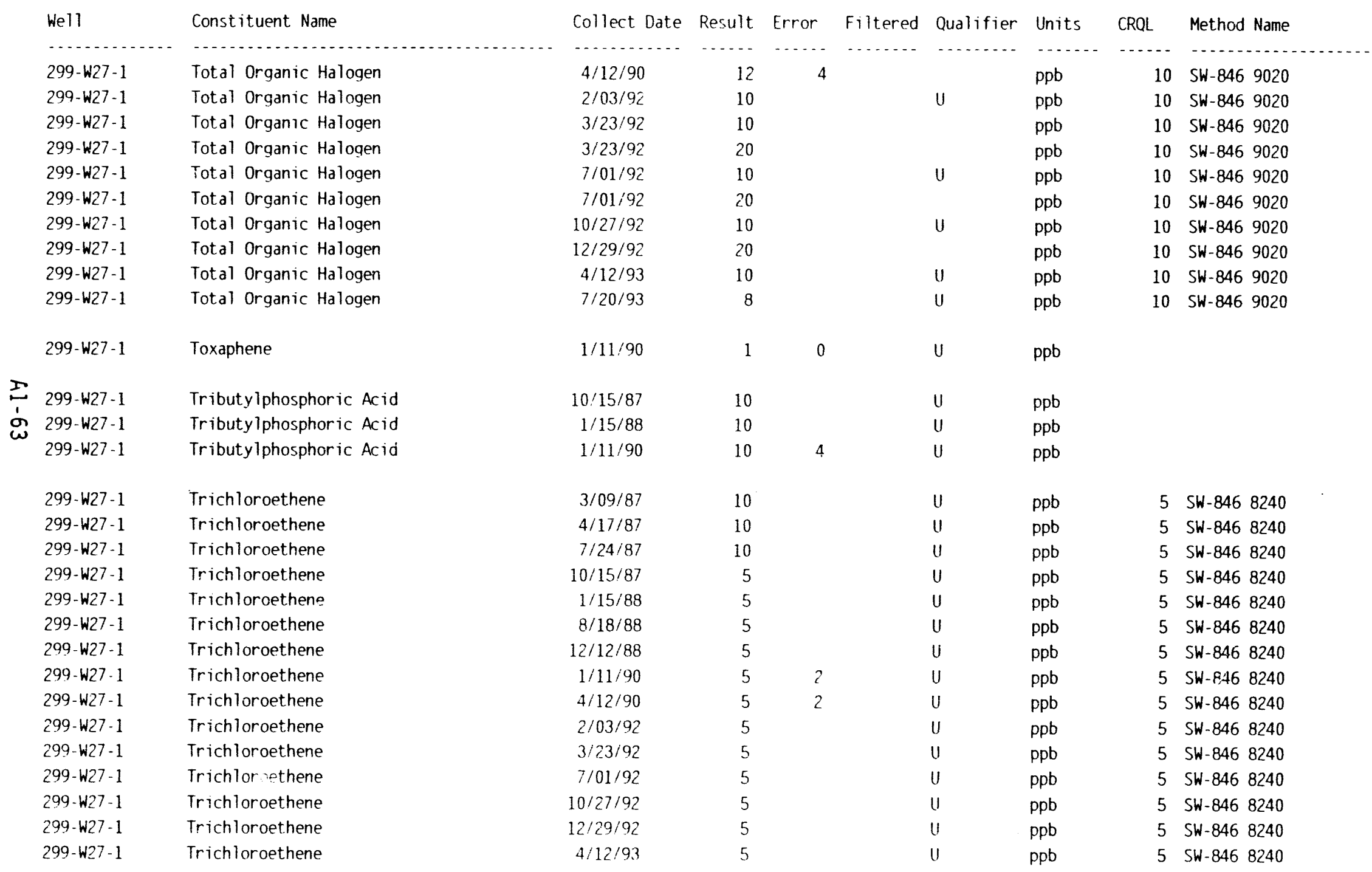




\begin{tabular}{|c|c|c|c|c|c|c|c|}
\hline Well & Constituent Name & Collect Date & Result & Error & Filtered & Qualifier & Units \\
\hline$\ldots \ldots . . . . . . .$. & $\ldots+\ldots, \ldots$ & $\ldots \ldots$ & $\ldots$ & - . . . & $\cdots$ & $\cdots$ & \\
\hline $299-W 27-1$ & Trichloromethanethiol & $7 / 24 / 87$ & 10 & & & U & $\mathrm{ppb}$ \\
\hline 299-W27-1 & Trichloromethanethiol & $10 / 15 / 87$ & 10 & & & U & $\mathrm{ppb}$ \\
\hline $299-W 27-1$ & Trichloromethanethiol & $1 / 15 / 88$ & 10 & & & U & $\mathrm{ppb}$ \\
\hline $299-W 27-1$ & Trichloromethanethiol & $8 / 18 / 88$ & 10 & & & u & $\mathrm{ppb}$ \\
\hline $299-W 27-1$ & Trichloromethanethiol & $1 / 11 / 90$ & 10 & 4 & & U & $\mathrm{ppb}$ \\
\hline 299-W27-1 & Trichloromonofluoromethane & $7 / 24 / 87$ & 10 & & & $\mathrm{U}$ & $\mathrm{ppb}$ \\
\hline 299-W27-1 & Trichloromonofluoromethane & $10 / 15 / 87$ & 10 & & & U & $\mathrm{ppb}$ \\
\hline 299-W27-1 & Trichloromonofluoromethane & $1 / 15 / 88$ & 10 & & & $U$ & $\mathrm{ppb}$ \\
\hline 299-W27-1 & Trichloromonofluoromethane & $8 / 18 / 88$ & 10 & & & u & $\mathrm{ppb}$ \\
\hline 299-W27-1 & Trichloromonofluoromethane & $1 / 11 / 90$ & 10 & 4 & & U & $\mathrm{ppb}$ \\
\hline $299-W 27-1$ & Tris(2.3-dibromopropy1) phosphate & $1 / 15 / 88$ & 10 & & & u & $\mathrm{ppb}$ \\
\hline $299-W 27-1$ & Tris(2.3-dibromopropyl) phosphate & $1 / 11 / 90$ & 10 & 4 & & $u$ & $\mathrm{ppb}$ \\
\hline $299-W 27-1$ & Tritium & $7 / 18 / 84$ & 145000 & & & & $\mathrm{pCi} / \mathrm{L}$ \\
\hline $299-W 27-1$ & Tritium & $8 / 06 / 84$ & 11700 & & & & $\mathrm{pCi} / \mathrm{L}$ \\
\hline 299-W27-1 & Tritium & $10 / 09 / 84$ & 117000 & & & & $\mathrm{pCi} / \mathrm{L}$ \\
\hline $299-W 27-1$ & Tritium & $11 / 05 / 84$ & 196000 & & & & $\mathrm{pCi} / \mathrm{L}$ \\
\hline 299-W27-1 & Tritium & $12 / 06 / 84$ & 166000 & & & & $\mathrm{pCi} / \mathrm{L}$ \\
\hline $299-W 27-1$ & Tritium & $1 / 08 / 85$ & 122000 & & & & $\mathrm{pCi} / \mathrm{L}$ \\
\hline 299-W27-1 & Tritium & $4 / 15 / 85$ & 102000 & & & & $\mathrm{pCi} / \mathrm{L}$ \\
\hline 299-W27-1 & Tritium & $7 / 11 / 85$ & 98000 & 6110 & & & $\mathrm{pCi} / \mathrm{L}$ \\
\hline 299-W27-1 & Tritium & $10 / 08 / 85$ & 637000 & 29400 & & & $\mathrm{pCi} / \mathrm{L}$ \\
\hline 299-W27-1 & Tritium & $1 / 07 / 86$ & 26700 & 3360 & & & $\mathrm{pCi} / \mathrm{L}$ \\
\hline $299-W 27-1$ & Tritium & $4 / 07 / 86$ & 11500 & 2210 & & & $\mathrm{pCj} / \mathrm{L}$ \\
\hline 299-W27-1 & Tritium & $7 / 02 / 86$ & 7360 & 2020 & & & $\mathrm{pCi} / \mathrm{L}$ \\
\hline $299-W 27-1$ & Tritium & $11 / 25 / 86$ & 19100 & 2970 & & & $\mathrm{pCi} / \mathrm{L}$ \\
\hline 299-W27-1 & Tritium & $1 / 20 / 87$ & 14500 & 2270 & & & $\mathrm{pCi} / \mathrm{L}$ \\
\hline $299-W 27-1$ & Tritium & $4 / 17 / 87$ & 7510 & 1930 & & & $\mathrm{pCi} / \mathrm{L}$ \\
\hline 299-W27-1 & Tritium & $7 / 23 / 87$ & 987 & 1580 & & U & $\mathrm{pCi} / \mathrm{L}$ \\
\hline
\end{tabular}




$\begin{array}{ll}\text { 299-W27-1 } & \text { Turbidity } \\ \text { 299-W27-1 } & \text { Uranium } \\ \text { 299-W27-1 } & \text { Uranium } \\ \text { 299-W27-1 } & \text { Uranium } \\ 299-W 27-1 & \text { Uranium } \\ \text { 299-W27-1 } & \text { Uranium } \\ \text { 299-W27-1 } & \text { Uranium } \\ \text { 299-W27-1 } & \text { Uranium } \\ \text { 299-W27-1 } & \text { Uranium } \\ 299-W 27-1 & \text { Uranium } \\ 299-W 27-1 & \text { Uranium } \\ 299-W 27-1 & \text { Uranium } \\ 299-W 27-1 & \text { Uranium } \\ 299-W 27-1 & \text { Uranium }\end{array}$




\begin{tabular}{|c|c|c|c|c|c|c|c|c|c|}
\hline Well & Constituent Name & Collect Date & Result & Error & Filtered & Qualifier & Units & CROL & Method Name \\
\hline -.......... &  & , & $\cdots \cdots$ & $-\cdots$ & $\cdots+$ & $\cdots$ & $\cdots \cdot$ & $\cdots$ & $\cdots$ \\
\hline 299-W27-1 & Uranium & $5 / 16 / 88$ & 14 & 4 & & & $\mathrm{pCi} / \mathrm{L}$ & & \\
\hline $299-W 27-1$ & Uranium & $8 / 18 / 88$ & 13 & 4 & & & $\mathrm{pCi/L}$ & & \\
\hline 299-W27-1 & Uranium & $12 / 15 / 88$ & 9 & 2 & & & $\mathrm{pCi} / \mathrm{L}$ & & \\
\hline $299-\$ 27-1$ & Uranium & $2 / 01 / 89$ & 11 & 3 & & & $\mathrm{pCi} / \mathrm{L}$ & & \\
\hline 299-W27-1 & Uranium & $1 / 11 / 90$ & 6 & 2 & & & $\mathrm{pCi} / \mathrm{L}$ & & \\
\hline 299-W27-1 & Uranium & $2 / 03 / 92$ & 7 & 1 & & & $\mathrm{ppb}$ & 1 & ITAS Gross U \\
\hline 299-W27-1 & Uranium & $3 / 23 / 92$ & 7 & 2 & & & $\mathrm{ppb}$ & 1 & ITAS Gross U \\
\hline 299-W27-1 & Uranium & $7 / 01 / 92$ & 6 & 2 & & & $\mathrm{ppb}$ & 1 & ITAS Gross U \\
\hline $299-W 27-1$ & Uranium & $10 / 27 / 92$ & 6 & 2 & & & $\mathrm{ppb}$ & 1 & ITAS Gross U \\
\hline $299-W 27-1$ & Uranium & $12 / 29 / 92$ & 8 & 2 & & & $\mathrm{ppb}$ & 1 & ITAS Gross U \\
\hline 299-W27-1 & Uranium & $7 / 20 / 93$ & 5 & 1 & & & $\mathrm{ppb}$ & 1 & ITAS Gross U \\
\hline 299-W27-1 & Ur anium-234 & $1 / 15 / 88$ & 5 & 1 & & & $\mathrm{pCi} / \mathrm{L}$ & & \\
\hline $299-W 27-1$ & Uranium-234 & $5 / 16 / 88$ & 5 & 1 & & & $\mathrm{pCi} / \mathrm{L}$ & & \\
\hline $299-W 27-1$ & Uranium-234 & $8 / 18 / 88$ & 4 & 0 & & & $\mathrm{pCi} / \mathrm{L}$ & & \\
\hline 299-W27-1 & Uranium-234 & $12 / 15 / 88$ & 5 & 0 & & & $\mathrm{pCi} / \mathrm{L}$ & & \\
\hline $299-W 27-1$ & Uranium-234 & $2 / 01 / 89$ & 4 & 0 & & & $\mathrm{pCi} / \mathrm{L}$ & & \\
\hline 299-W27-1 & Uranium-235 & $1 / 15 / 88$ & 0 & 0 & & & $\mathrm{pCi} / \mathrm{L}$ & & \\
\hline 299-W27-1 & Uranium-235 & $5 / 16 / 88$ & 0 & 0 & & & $\mathrm{pCi} / \mathrm{L}$ & & \\
\hline 299-W27-1 & Uranium-235 & $8 / 18 / 88$ & 0 & 0 & & & $\mathrm{pCi} / \mathrm{L}$ & & \\
\hline $299-W 27-1$ & Uranium-235 & $12 / 15 / 88$ & 0 & 0 & & & $\mathrm{pCi} / \mathrm{L}$ & & \\
\hline $299-w^{2} 7-1$ & Uranium-235 & 2/01/89 & 0 & 0 & & & $\mathrm{pCi} / \mathrm{L}$ & & \\
\hline 299-W27-1 & Uranium-238 & $1 / 15 / 88$ & 4 & 0 & & & $\mathrm{pCi} / \mathrm{L}$ & & \\
\hline $299-W 27-1$ & Uranium-238 & $5 / 16 / 88$ & 5 & 0 & & & $\mathrm{pCi} / \mathrm{L}$ & & \\
\hline 299-W27-1 & Uranium-238 & $8 / 18 / 88$ & 4 & 0 & & & $\mathrm{pCi} / \mathrm{L}$ & & \\
\hline 299-W27-1 & Uranium-238 & $12 / 15 / 88$ & 4 & 0 & & & $\mathrm{pCi} / \mathrm{L}$ & & \\
\hline $299-W 27-1$ & Uranium-238 & $2 / 01 / 89$ & 3 & 0 & & & $\mathrm{pCi} / \mathrm{L}$ & & \\
\hline 299-W27-1 & Uranium-238 & $4 / 12 / 93$ & 5 & 1 & & & $\mathrm{ppb}$ & 1 & ITAS Gross U \\
\hline 299-W27-1 & Vanadium & $1 / 15 / 88$ & 16 & & & & ppb & & \\
\hline
\end{tabular}




\begin{tabular}{|c|c|c|c|c|c|c|c|c|c|}
\hline Well & Constituent Name & Collect Date & Rerult & Error & Filtered & Qualifier & Units & CRQL & Method Name \\
\hline$\ldots . . . .$. & $\ldots \ldots \ldots$ & $\ldots \ldots \ldots$ & $\cdots \cdots$ & $\cdots$ & & $\cdots$ & $\cdots$ & $\cdots \cdots$ & $\cdots$ \\
\hline $299-\$ 27-1$ & Vanadium & $1 / 11 / 90$ & 19 & 4 & & & $\mathrm{ppb}$ & & \\
\hline $299-W 27-1$ & Vanadium. filtered & $3 / 09 / 87$ & 15 & & Y & & $\mathrm{ppb}$ & 30 & SW 8466010 \\
\hline 299-W27-1 & Vanadium. filtered & $4 / 17 / 87$ & 15 & & r & & $\mathrm{ppb}$ & 30 & SW-846 6010 \\
\hline $299-W 27-1$ & Vanadium. filtered & $7 / 24 / 87$ & 13 & & Y & & $p p b$ & 30 & SW-846 6010 \\
\hline 299-W27-1 & Vanadium. filtered & $10 / 15 / 87$ & 18 & & $\gamma$ & & $\mathrm{ppb}$ & 30 & SW-846 6010 \\
\hline $299-W 27-1$ & Vanadium. filtered & $1 / 15 / 88$ & 18 & & Y & & $\mathrm{ppb}$ & 30 & SW-846 6010 \\
\hline $299-W 27-1$ & Vanadium. filtered & $8 / 18 / 88$ & 24 & & r & & $\mathrm{ppb}$ & 30 & SW-846 6010 \\
\hline $299-W 27-1$ & Vanadium. filtered & $12 / 12 / 88$ & 19 & & Y & & $\mathrm{ppb}$ & 30 & SW-846 6010 \\
\hline $299-W 27-1$ & Vanadium. filtered & $1 / 11 / 90$ & 18 & 4 & Y & & $\mathrm{ppb}$ & 30 & SW-846 6010 \\
\hline $299-W 27-1$ & Vanadium. filtered & $4 / 12 / 90$ & 16 & 4 & r & & $\mathrm{ppb}$ & 30 & SW-846 6010 \\
\hline $299-W 27-1$ & Vanadium. filtered & $4 / 12 / 90$ & 20 & 4 & Y & & $\mathrm{ppb}$ & 30 & SW-846 6010 \\
\hline $299-W 27-1$ & Vanadium. filtered & $2 / 03 / 92$ & 30 & & Y & $u$ & $p p b$ & 30 & SW-846 6010 \\
\hline $299-W 27-1$ & Vanadium. filtered & $3 / 23 / 92$ & 30 & & Y & U & $\mathrm{ppb}$ & 30 & SW-846 6010 \\
\hline $299-W 27-1$ & Vanadium. filtered & $7 / 01 / 92$ & 30 & & r & 11 & $\mathrm{ppb}$ & 30 & SW-846 6010 \\
\hline 299-W27-1 & Vanadium. filtered & $10 / 27 / 92$ & 30 & & Y & u & $\mathrm{ppb}$ & 30 & SW-846 6010 \\
\hline $299 \cdot W 27-1$ & Vanadium. filtered & $12 / 29 / 92$ & 30 & & Y & U & $\mathrm{ppb}$ & 30 & SW-846 6010 \\
\hline $299-W 27-1$ & Vanadium. filtered & $4 / 12 / 93$ & 30 & & Y & u & $\mathrm{ppb}$ & 30 & SW-846 6010 \\
\hline $299-W 27-1$ & Vinyl acetate & $1 / 11 / 90$ & 5 & 2 & & U & $\mathrm{ppb}$ & 5 & SW-846 8240 \\
\hline $299-W 27-1$ & Vinyl chloride & $7 / 24 / 87$ & 10 & & & U & $\mathrm{ppb}$ & 10 & SW-846 8240 \\
\hline $299-W 27-1$ & Vinyl chloride & $10 / 15 / 87$ & 10 & & & U & $\mathrm{ppb}$ & 10 & SW-846 8240 \\
\hline $299-W 27-1$ & Vinyl chloride & $1 / 15 / 88$ & 10 & & & U & $\mathrm{ppb}$ & 10 & SW-846 8240 \\
\hline 299-W27-1 & Vinyl chloride & $8 / 18 / 88$ & 10 & & & U & $\mathrm{ppb}$ & 10 & SW-846 8240 \\
\hline $299-W 27-1$ & Vinyl chloride & $1 / 11 / 90$ & 10 & 4 & & U & $\mathrm{ppb}$ & 10 & SW-846 8240 \\
\hline 299-W27-1 & Vinyl chloride & $4 / 12 / 90$ & 10 & 4 & & U & $\mathrm{ppb}$ & 10 & SW-846 8240 \\
\hline $299-W 27-1$ & Vinyl chloride & $2 / 03 / 92$ & 10 & & & 11 & ppb & 10 & SW-846 8240 \\
\hline $299-W 27-1$ & Vinyl chloride & $3 / 23 / 92$ & 10 & & & 11 & $\mathrm{ppb}$ & 10 & SW-846 8240 \\
\hline $299-W 27-1$ & Vinyl chloride & $7 / 01 / 92$ & 10 & & & U & $p p b$ & 10 & SW-846 8240 \\
\hline $299 \cdot W 27-1$ & Vinyl chloride & $10 / 27 \cdot 92$ & 10 & & & U & $\mathrm{ppb}$ & 10 & SW-846 8240 \\
\hline $299-w 27-1$ & Vinyl chloride & $12 / 29 / 92$ & 10 & & & 11 & $\mathrm{ppb}$ & 10 & SW-846 8240 \\
\hline $299-W 27-1$ & Vinvl chloride & $4: 12 / 93$ & 10 & & & 11 & $\mathrm{ppb}$ & 10 & SW-846 8240 \\
\hline
\end{tabular}




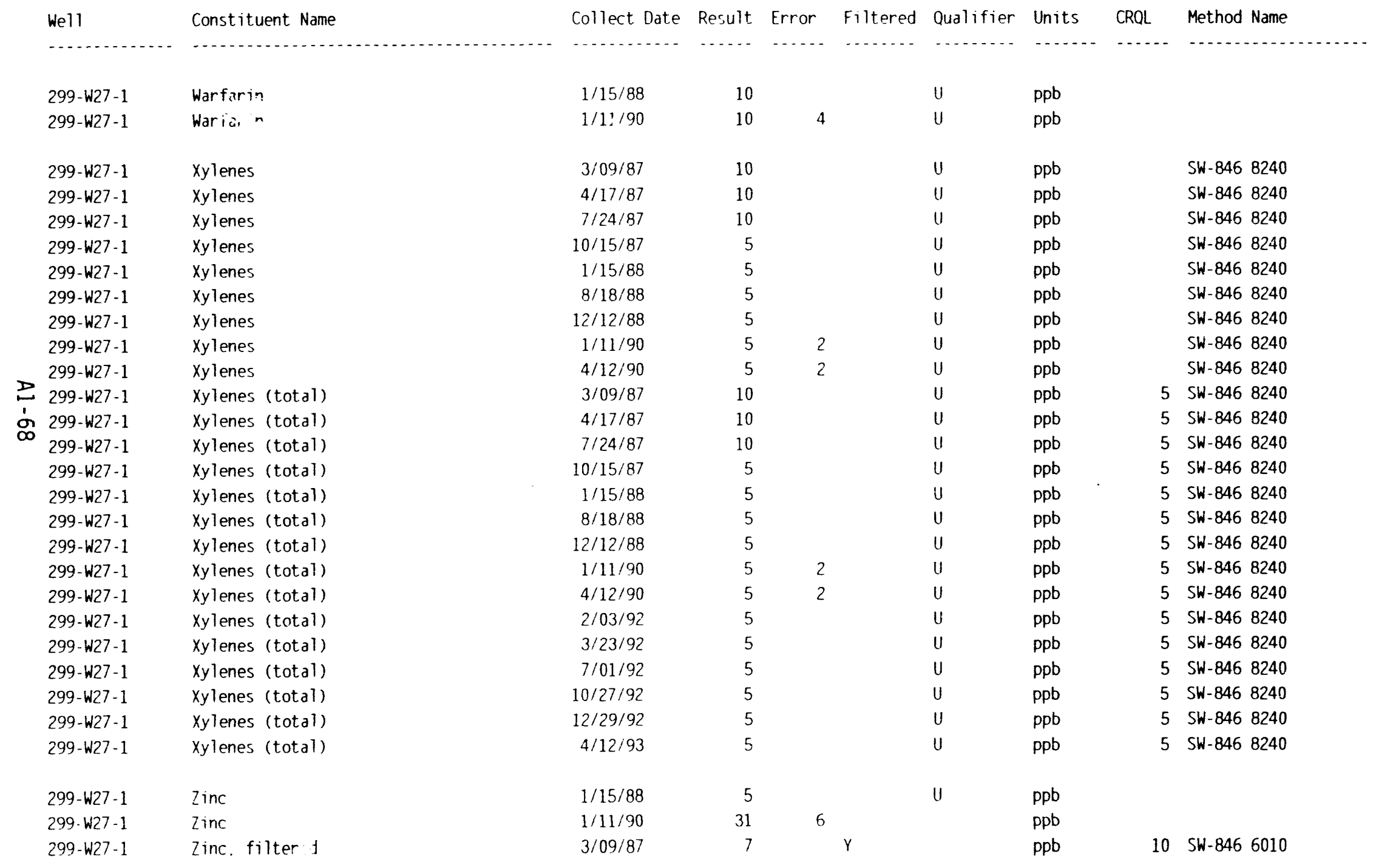


11/08/93 Groundwater Well Results for 299-W27-1 Page 68

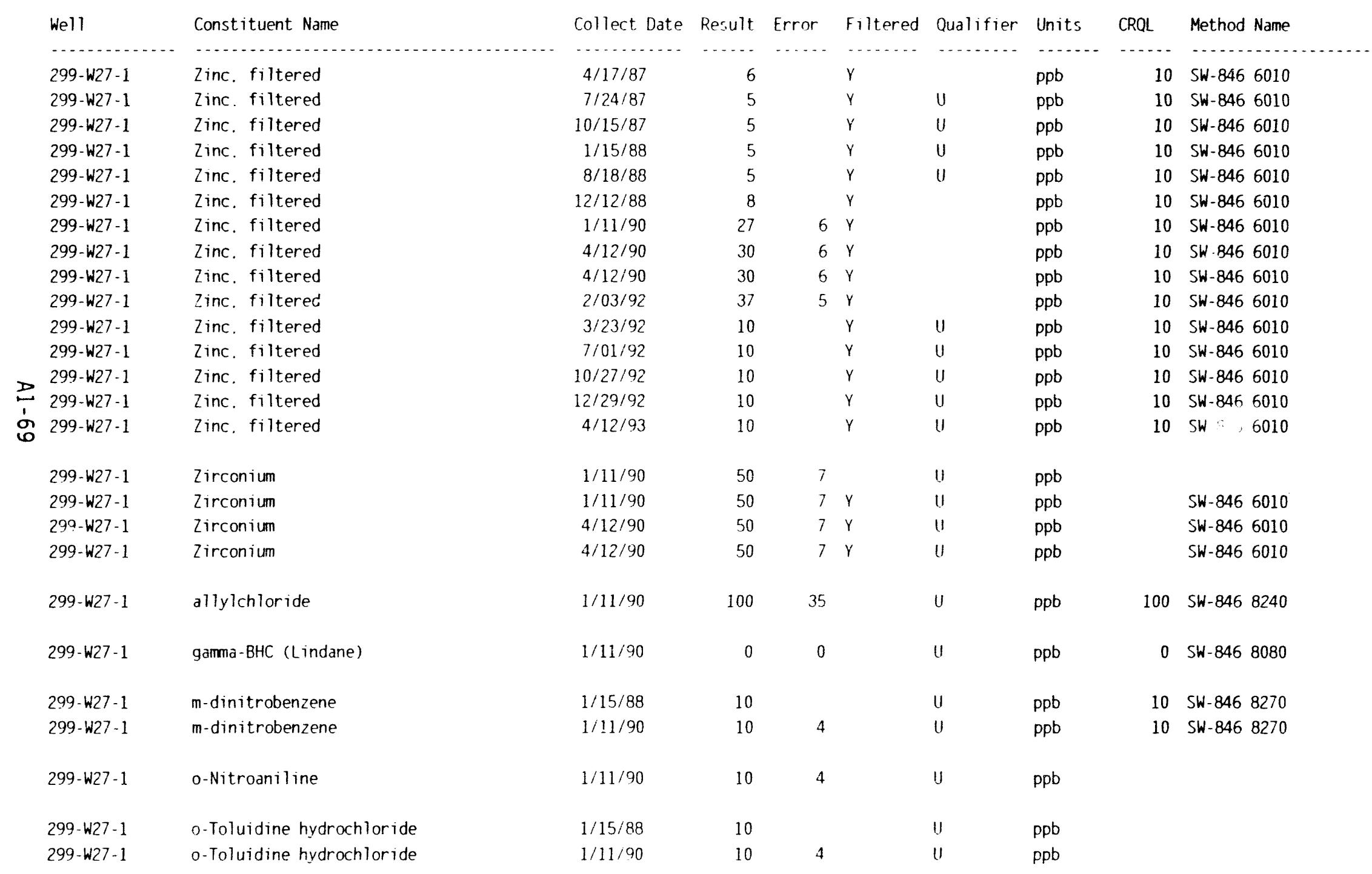




\begin{tabular}{|c|c|c|c|c|c|c|c|c|c|}
\hline Well & Constituent Name & Collect Date & Result & Error & Filtered & Qualifier & Units & $\mathrm{CRQL}$ & Method Name \\
\hline 299-W27-1 & p-Benzoquinone & $1 / 15 / 88$ & 10 & & & u & $\mathrm{ppb}$ & & \\
\hline 299-W27-1 & p-Benzoquinone & $1 / 11 / 90$ & 10 & 4 & & $u$ & $\mathrm{ppb}$ & & \\
\hline 299-W27-1 & p-Dimethy laminoazobenzene & $1 / 15 / 88$ & 10 & & & u & $\mathrm{ppb}$ & & \\
\hline $299-W 27-1$ & p-Dimethy laminoazobenzene & $1 / 11 / 90$ & 10 & 4 & & u & $\mathrm{ppb}$ & & \\
\hline 299-W27-1 & $\mathrm{pH}$ & $3 / 09 / 87$ & 8 & & & & & & \\
\hline 299-W27-1 & $\mathrm{pH}$ & $3 / 09 / 87$ & 8 & & & & & & \\
\hline 299-W27-1 & $\mathrm{pH}$ & $4 / 17 / 87$ & 8 & & & & & & \\
\hline 299-W27-1 & $\mathrm{pH}$ & $4 / 17 / 87$ & 8 & & & & & & \\
\hline 299-W27-1 & $\mathrm{pH}$ & $7 / 24 / 87$ & 7 & & & & & & \\
\hline 299-W27-1 & $\mathrm{pH}$ & $7 / 24 / 87$ & 8 & & & & & & \\
\hline $299-W 27-1$ & $\mathrm{pH}$ & $10 / 15 / 87$ & 7 & & & & & & \\
\hline 299-W27-1 & $\mathrm{pH}$ & $10 / 15 / 87$ & 8 & & & & & & \\
\hline 299-W27-1 & $\mathrm{pH}$ & $1 / 15 / 88$ & 8 & & & & & & \\
\hline 299-W27-1 & $\mathrm{pH}$ & $1 / 15 / 88$ & 8 & & & & & & \\
\hline 299-W27-1 & $\mathrm{pH}$ & $8 / 18 / 88$ & 8 & & & & & & \\
\hline 299-W27-1 & $\mathrm{pH}$ & $8 / 18 / 88$ & 8 & & & & & & \\
\hline 299-W27-1 & $\mathrm{pH}$ & $12 / 12 / 88$ & 8 & & & & & & \\
\hline 299-W27-1 & $\mathrm{pH}$ & $12 / 12 / 88$ & 8 & & & & & & \\
\hline 299-W27-1 & $\mathrm{pH}$ & $1 / 11 / 90$ & 8 & 0 & & & & & \\
\hline 299-W27-1 & $\mathrm{pH}$ & $1 / 11 / 90$ & 8 & & & & & & \\
\hline 299-W27-1 & $\mathrm{pH}$ & $4 / 12 / 90$ & 8 & 0 & & & & & \\
\hline 299-W27-1 & $\mathrm{pH}$ & $4 / 12 / 90$ & 8 & & & & & & \\
\hline 299-W27-1 & $\mathrm{pH}$ & $1 / 14 / 92$ & 8 & & & & & 0 & Probe. pH \\
\hline 299-W27-1 & $\mathrm{pH}$ & $2 / 03 / 92$ & 8 & & & & $\mathrm{pH}$ & & ASTM D-1293 \\
\hline 299-W27-1 & $\mathrm{pH}$ & $2 / 03 / 92$ & 9 & & & & & 0 & Probe. $\mathrm{pH}$ \\
\hline 299-W27-1 & $\mathrm{pH}$ & $3 / 23 / 92$ & 8 & & & & $\mathrm{pH}$ & & ASTM D-1293 \\
\hline 299-W27-1 & $\mathrm{pH}$ & $3 / 23 / 92$ & 8 & & & & & 0 & Probe. $\mathrm{pH}$ \\
\hline 299-W27-1 & $\mathrm{pH}$ & $7 / 01 / 92$ & 8 & & & & & 0 & Probe. $\mathrm{pH}$ \\
\hline 299-W27-1 & $\mathrm{pH}$ & $7 / 01 / 92$ & 8 & & & & $\mathrm{pH}$ & & ASTM D-1293 \\
\hline
\end{tabular}




\begin{tabular}{|c|c|c|c|c|c|c|c|c|}
\hline Well & Constituent Name & Collect Date & Result & Error Filtered & Qualifier & Units & $\mathrm{CRQL}$ & Mathod Name \\
\hline ................... & - & $\ldots \ldots \ldots$ & $\cdots$ & 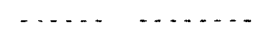 & 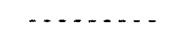 & -....... & ...... & $\ldots+\ldots$ \\
\hline $299-W 27-1$ & $\mathrm{pH}$ & $10 / 27 / 92$ & 8 & & & & 0 & Probe. $\mathrm{pH}$ \\
\hline $299-W 27-1$ & $\mathrm{pH}$ & $10 / 27 / 92$ & 8 & & & $\mathrm{pH}$ & & ASTM D-1293 \\
\hline 299-W27-1 & $\mathrm{pH}$ & $12 / 29 / 92$ & 8 & & & & 0 & Probe. $\mathrm{pH}$ \\
\hline 299-W27-1 & $\mathrm{pH}$ & $12 / 29 / 92$ & 8 & & & $\mathrm{pH}$ & & ASTM D-1293 \\
\hline $299-W 27-1$ & $\mathrm{pH}$ & $4 / 12 / 93$ & 9 & & & $\mathrm{pH}$ & & ASTM D-1293 \\
\hline 299-W27-1 & $\mathrm{pH}$ & $4 / 12 / 93$ & 9 & & & & 0 & Probe. $\mathrm{pH}$ \\
\hline $299-W 27-1$ & $\mathrm{pH}$ & $7 / 20 / 93$ & 8 & & & & 0 & Probe. $\mathrm{pH}$ \\
\hline 299-W27-1 & $\mathrm{pH}$ & $7 / 20 / 93$ & 8 & & & $\mathrm{pH}$ & & ASTM D-1293 \\
\hline $299-W 27-1$ & sym-Trinitrobenzene & $1 / 15 / 88$ & 10 & & U & ppb & & \\
\hline $299-W 27-1$ & sym-Trinitrobenzene & $1 / 11 / 90$ & 10 & 4 & U & ppb & & \\
\hline 299-W27-1 & trans-1.2-Dichloroethylene & $7 / 24 / 87$ & 10 & & U & $\mathrm{ppb}$ & 5 & SW-846 8240 \\
\hline $299-W 27-1$ & trans-1.2-Dichloroethylene & $10 / 15 / 87$ & 10 & & U & $\mathrm{ppb}$ & 5 & SW-846 8240 \\
\hline ㄴ $299-W 2 i-1$ & trans-1.2-Dichloroethylene & $1 / 15 / 88$ & 10 & & U & $\mathrm{ppb}$ & 5 & SW-846 8240 \\
\hline $299-W 27-1$ & trans-1.2-Dichloroethylene & $8 / 18 / 88$ & 10 & & U & $\mathrm{ppb}$ & 5 & SW-846 8240 \\
\hline $299-W 27-1$ & trans-1.2-Dichloroethylene & $1 / 11 / 90$ & 5 & 2 & U & $\mathrm{ppb}$ & 5 & SW- 8468240 \\
\hline $299-W 27-1$ & trans-1.2-Dichloroethylene & $4 / 12 / 90$ & 5 & 2 & U & $\mathrm{ppb}$ & 5 & SW-846 8240 \\
\hline $299-W 27-1$ & trans-1.2-Dichloroethylene & $2 / 03 / 92$ & 5 & & U & $\mathrm{ppb}$ & 5 & SW-846 8240 \\
\hline $299-W 27-1$ & trans-1.2-Dichloroethylene & $3 / 23 / 92$ & 5 & & U & $\mathrm{ppb}$ & 5 & SW-846 8240 \\
\hline $299-W 27-1$ & trans-1.2-Dichloroethylene & $7 / 01 / 92$ & 5 & & U & $\mathrm{ppb}$ & 5 & SW-846 8240 \\
\hline $299-W 27-1$ & trans-1.2-Dichloroethylene & $10 / 27 / 92$ & 5 & & U & $\mathrm{ppb}$ & 5 & SW-846 8240 \\
\hline 299-W27-1 & trans-1.2-Dichloroethylene & $12 / 29 / 92$ & 5 & & U & $\mathrm{ppb}$ & 5 & SW- 8468240 \\
\hline 299-W27-1 & trans-1.4-dichloro-2-butene & $7 / 24 / 87$ & 10 & & U & $\mathrm{ppb}$ & 5 & SW-846 8240 \\
\hline 299-W27-1 & trans-1.4-dichloro-2-butene & $10 / 15 / 87$ & 10 & & U & $\mathrm{ppb}$ & 5 & SW-846 8240 \\
\hline 299-W27-1 & trans-1.4-dichloro-2-butene & $1 / 15 / 88$ & 10 & & U & $\mathrm{ppb}$ & 5 & SW-846 8240 \\
\hline $299-W 27-1$ & trans-1.4-dichloro-2-butene & $8 / 18 / 88$ & 10 & & u & $\mathrm{ppb}$ & 5 & SW- 8468240 \\
\hline $299-W 27-1$ & trans-1.4-dichloro-2-butene & $1 / 11 / 90$ & 10 & 4 & U & $\mathrm{ppb}$ & 5 & SW- 8468240 \\
\hline
\end{tabular}


Summary of Provisional Hanford Site Groundwater Background Values (Johnson, 1993b). (3 sheets)

\begin{tabular}{|c|c|c|c|c|}
\hline $\begin{array}{c}\text { Constituent } \\
\text { (concentration) }\end{array}$ & PNL Results ${ }^{b}$ & $\begin{array}{l}\text { USGS Results } \\
\text { (sample size) }\end{array}$ & $\begin{array}{l}\text { WHC Unconfined } \\
\text { (sample size) }\end{array}$ & $\begin{array}{l}\text { WHC Provisional } \\
\text { Threshold Values }\end{array}$ \\
\hline $\begin{array}{l}\text { Aluminum } \\
\text { (ppb) }\end{array}$ & $<2$ & $\begin{array}{c}110 \pm 139 \\
(12)\end{array}$ & $\begin{array}{l}<200 \\
(50)\end{array}$ & $<200$ \\
\hline $\begin{array}{l}\text { Ammonium } \\
\text { (ppb) }\end{array}$ & $<50$ & NA & $\begin{array}{l}<50 \\
(18)\end{array}$ & $<120$ \\
\hline $\begin{array}{l}\text { Arsenic } \\
\text { (ppb) }\end{array}$ & $3.9 \pm 2.4$ & $\begin{array}{c}6.7 \pm 3.7 \\
(7)\end{array}$ & $\begin{array}{l}<5 \\
(14)\end{array}$ & 10 \\
\hline $\begin{array}{l}\text { Barium } \\
\text { (ppb) }\end{array}$ & $42 \pm 20$ & $\begin{array}{c}53 \pm 14 \\
(11)^{2}\end{array}$ & $\begin{array}{l}41 \pm 20 \\
(53)\end{array}$ & 68.5 \\
\hline $\begin{array}{l}\text { Beryllium } \\
\text { (ppb) }\end{array}$ & $<0.3$ & NA & $\begin{array}{l}<5 \\
(16)\end{array}$ & $<5$ \\
\hline $\begin{array}{l}\text { Bismuth } \\
\text { (ppb) }\end{array}$ & $<0.02$ & NA & $\begin{array}{l}<5 \\
(4)\end{array}$ & $<5$ \\
\hline $\begin{array}{l}\text { Boron } \\
\text { (ppb) }\end{array}$ & $<50$ & $\begin{array}{l}<50 \\
(14)\end{array}$ & $\begin{array}{l}<100 \\
(35)\end{array}$ & $<100$ \\
\hline $\begin{array}{l}\text { Cadmium } \\
\text { (ppb) }\end{array}$ & $<0.2$ & $\begin{array}{l}<10 \\
(1)\end{array}$ & $\begin{array}{l}<10 \\
(16)\end{array}$ & $<10$ \\
\hline $\begin{array}{l}\text { Calcium } \\
\text { (ppb) }\end{array}$ & $40,400 \pm 10,300$ & $\begin{array}{c}40,857 \pm 8,282 \\
(14)\end{array}$ & $\begin{array}{c}38,542 \pm 11,023 \\
(53)^{19}\end{array}$ & 63,600 \\
\hline $\begin{array}{l}\text { Chloride-low } \\
\text { (ppb) }\end{array}$ & NA & $\begin{array}{c}5.825 \pm 1.355 \\
(8)\end{array}$ & $\begin{array}{c}5,032 \pm 1,774 \\
(53)\end{array}$ & 8,690 \\
\hline $\begin{array}{l}\text { Chloride-high } \\
\text { (ppb) }\end{array}$ & NA & $\begin{array}{c}20,667 \pm 2,503 \\
(6)\end{array}$ & $\begin{array}{c}23,296 \pm 2,463 \\
(14)\end{array}$ & 28,500 \\
\hline $\begin{array}{c}\text { Chloride-all } \\
\text { (ppb) }\end{array}$ & $10,300 \pm 6,500$ & $\begin{array}{c}12,186 \pm 7,842 \\
(14)\end{array}$ & $\begin{array}{c}8,848 \pm 7,723 \\
(67)\end{array}$ & NC \\
\hline $\begin{array}{c}\text { Chromium } \\
(\mathrm{ppb})\end{array}$ & $4 \pm 2$ & $\begin{array}{r}<50 \\
(11) \\
\end{array}$ & $\begin{array}{l}<30 \\
(8)\end{array}$ & $<30$ \\
\hline $\begin{array}{l}\text { Copper } \\
\text { (ppb) }\end{array}$ & $<1$ & $\begin{array}{l}<10 \\
(10)\end{array}$ & $\begin{array}{r}<30 \\
(50) \\
\end{array}$ & $<30$ \\
\hline $\begin{array}{c}\text { Fluoride } \\
\text { (ppb) }\end{array}$ & $370 \pm 100$ & $\begin{array}{c}550 \pm 330 \\
(14)\end{array}$ & $\begin{array}{c}437 \pm 131^{c} \\
(47)\end{array}$ & $\begin{array}{l}1,340 \\
775^{\mathrm{C}} \\
\end{array}$ \\
\hline $\begin{array}{l}\text { Iron-10w } \\
\text { (ppb) }\end{array}$ & NA & $22 \pm 16^{c}$ & $\begin{array}{l}<50 \\
(34)\end{array}$ & 86 \\
\hline $\begin{array}{l}\text { Iron-mid } \\
(\mathrm{ppb})\end{array}$ & NA & NA & $\begin{array}{c}115 \pm 52 \\
(7)\end{array}$ & 291 \\
\hline $\begin{array}{l}\text { Iron*high } \\
\text { (ppb) }\end{array}$ & NA & NA & $\begin{array}{c}494 \pm 118 \\
(12)^{18}\end{array}$ & 818 \\
\hline $\begin{array}{l}\text { Iron-all } \\
(p p b)\end{array}$ & NA & NA & $\begin{array}{c}149 \pm 199 \\
(53)\end{array}$ & NC \\
\hline $\begin{array}{l}\text { Lead } \\
\text { (ppb) }\end{array}$ & $<0.5$ & $\begin{array}{l}<30^{c} \\
(B)\end{array}$ & $\begin{array}{l}<5 \\
(15)\end{array}$ & $<5$ \\
\hline $\begin{array}{l}\text { Magnesium } \\
(\mathrm{ppb})\end{array}$ & $11,800 \pm 3,400$ & $\begin{array}{c}10,814 \pm 1,813 \\
(14)\end{array}$ & $\begin{array}{c}11,190 \pm 2,578 \\
(14)\end{array}$ & 16,840 \\
\hline $\begin{array}{l}\text { Manganese- low } \\
(p p b)\end{array}$ & NA & $\begin{array}{c}26 \pm 27 \\
(8)\end{array}$ & $\begin{array}{l}<20 \\
(33)\end{array}$ & 24.5 \\
\hline $\begin{array}{l}\text { Manganese-high } \\
(p p b)\end{array}$ & NA & $\begin{array}{c}150 \pm 87 \\
(3)\end{array}$ & $\begin{array}{l}118 \pm 17 \\
(20)\end{array}$ & 163.5 \\
\hline
\end{tabular}




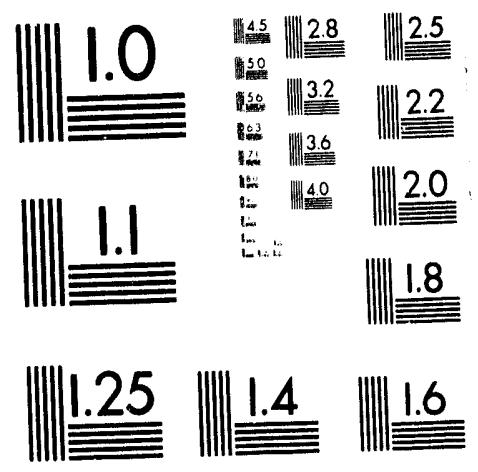



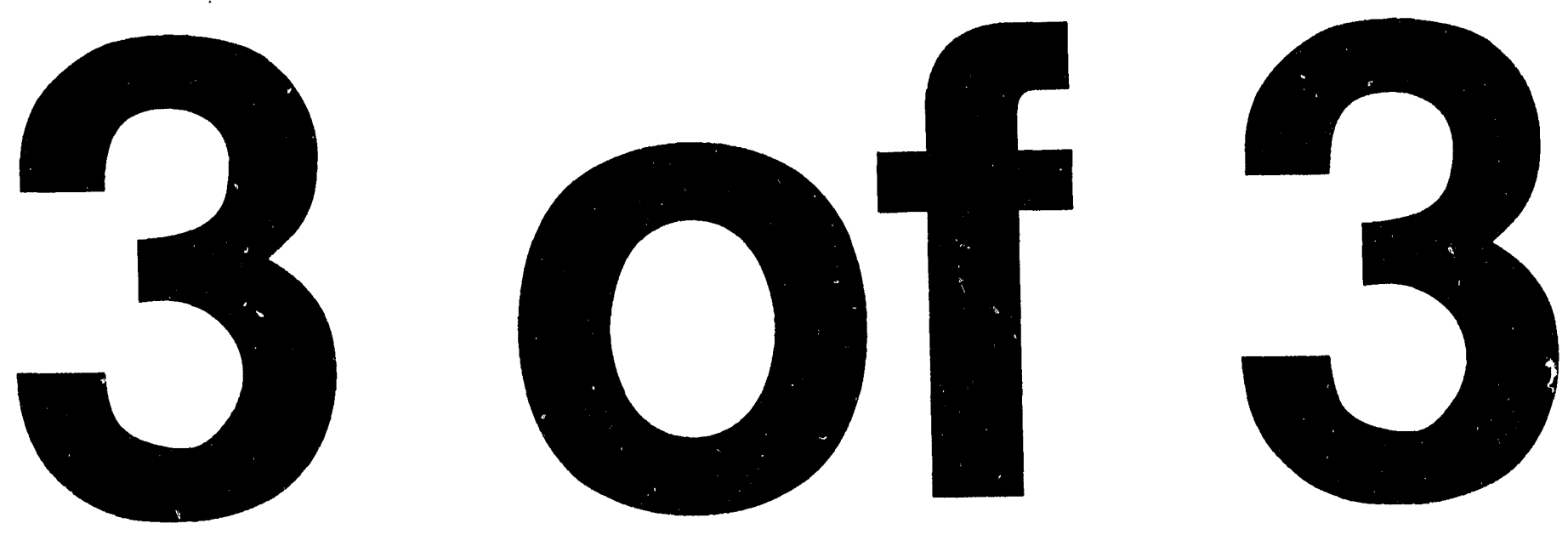
Summary of Provisional Hanford Site Groundwater Background Values (Johnson, 1993b). (3 sheets)

\begin{tabular}{|c|c|c|c|c|}
\hline $\begin{array}{l}\text { Constituent } \\
\text { (concentration) }\end{array}$ & PNL Results ${ }^{b}$ & $\begin{array}{l}\text { USGS Results } \\
\text { (sample size) }\end{array}$ & $\begin{array}{l}\text { WHC Unconf ined } \\
\text { (sample size) }\end{array}$ & $\begin{array}{l}\text { WHC Provisional } \\
\text { Threshold Values }\end{array}$ \\
\hline $\begin{array}{c}\text { Manganese-all } \\
(p p b)\end{array}$ & $\cdots$ & $\begin{array}{l}60 \pm 73 \\
(11)\end{array}$ & $\begin{array}{c}50 \pm 55 \\
(53)\end{array}$ & NC \\
\hline $\begin{array}{c}\text { Mercury } \\
\text { (ppb) }\end{array}$ & $\cdots$ & NA & $\begin{array}{l}<0.1 \\
(14)\end{array}$ & $<0.1$ \\
\hline $\begin{array}{l}\text { Nickel } \\
\text { (ppb) }\end{array}$ & $<4$ & $\begin{array}{l}<50 \\
(14)\end{array}$ & $\begin{array}{l}<30 \\
(23)\end{array}$ & $<30$ \\
\hline $\begin{array}{l}\text { Nitrate } \\
\text { (ppb) }\end{array}$ & NA & $\begin{array}{c}3,224 \pm 3,380 \\
(13)^{2}\end{array}$ & $\begin{array}{c}5,170 \pm 3,576 \\
(78)\end{array}$ & 12,400 \\
\hline $\begin{array}{l}\text { Phosphate } \\
\text { (ppb) }\end{array}$ & $<1000$ & $\begin{array}{c}140 \pm 62 \\
(3)\end{array}$ & $<1,000$ & $<1,000$ \\
\hline $\begin{array}{l}\text { Potassium } \\
\text { (ppb) }\end{array}$ & $4,950 \pm 1,240$ & $\begin{array}{c}5,900 \pm 1,253 \\
(14)\end{array}$ & $\begin{array}{c}4,993 \pm 1,453 \\
(53)\end{array}$ & 7.975 \\
\hline $\begin{array}{l}\text { Selenium } \\
\text { (ppb) }\end{array}$ & $<2$ & NA & $\begin{array}{l}<5 \\
(14)\end{array}$ & $<5$ \\
\hline $\begin{array}{l}\text { silver } \\
\text { (ppb) }\end{array}$ & $<10$ & NA & $<10$ & $<10$ \\
\hline $\begin{array}{l}\text { silicon } \\
\text { (ppb) }\end{array}$ & NA & $\begin{array}{c}16,786 \pm 3,683 \\
(14)\end{array}$ & $\begin{array}{c}18,152 \pm 4,974 \\
(35)\end{array}$ & 26,500 \\
\hline $\begin{array}{l}\text { Sodium } \\
\text { (ppb) }\end{array}$ & $18,260 \pm 10.150$ & $\begin{array}{c}20,286 \pm 7,907 \\
(14)\end{array}$ & $\begin{array}{c}15,774 \pm 6,784 \\
(53)\end{array}$ & 33,500 \\
\hline $\begin{array}{l}\text { Strontium } \\
\text { (ppb) }\end{array}$ & $236 \pm 102$ & $\begin{array}{c}159 \pm 78 \\
(14)\end{array}$ & $\begin{array}{c}164 \pm 47 \\
(43)\end{array}$ & 264.1 \\
\hline $\begin{array}{l}\text { Sulfate } \\
(p p b)\end{array}$ & $34,300 \pm 16,900$ & $\begin{array}{c}41,286 \pm 27,880 \\
(14)\end{array}$ & $\begin{array}{c}30,605 \pm 22,611 \\
(67)\end{array}$ & 90,500 \\
\hline $\begin{array}{l}\text { Uranium } \\
(\mathrm{pCi} / L)\end{array}$ & $1.7 \pm 0.8$ & NA & $\begin{array}{c}1.7 \pm 1.2 \\
(10)\end{array}$ & 3.43 \\
\hline $\begin{array}{l}\text { Vanadium } \\
\text { (ppb) }\end{array}$ & $17 \pm 9$ & NA & $\begin{array}{r}9 \pm 4 \\
(18) \\
\end{array}$ & 15 \\
\hline $\begin{array}{l}2 \text { inc-low } \\
(p p b)\end{array}$ & NA & $\begin{array}{c}14 \pm 20 \\
(11)\end{array}$ & $\begin{array}{l}<50 \\
(36) \\
\end{array}$ & $<50$ \\
\hline $\begin{array}{l}\text { 2inc-high } \\
(\mathrm{ppb})\end{array}$ & NA & $\begin{array}{c}373 \pm 284 \\
(3)\end{array}$ & $\begin{array}{c}247 \pm 165 \\
(17)\end{array}$ & 673 \\
\hline $\begin{array}{c}\text { 2inc-all } \\
\text { (ppb) }\end{array}$ & $6 \pm 2$ & $\begin{array}{c}91 \pm 190 \\
(14)\end{array}$ & $\begin{array}{c}95 \pm 140 \\
(53)\end{array}$ & NC \\
\hline $\begin{array}{l}\text { Field alkalinity } \\
(\mathrm{ppb})\end{array}$ & NA & $\begin{array}{c}134,100 \pm 20,469 \\
(10)\end{array}$ & $\begin{array}{c}137,758 \pm 33,656 \\
(31)\end{array}$ & 215,000 \\
\hline $\begin{array}{c}\text { Lab alkalinity } \\
\text { (ppb) }\end{array}$ & $123,000 \pm 21,000$ & $\begin{array}{c}130,000 \pm 8,165 \\
(4)\end{array}$ & $\begin{array}{c}133,717 \pm 29,399 \\
(52)\end{array}$ & 210,000 \\
\hline Field $\mathrm{pH}$ & NA & NA & $\begin{array}{c}7.57 \pm 0.29 \\
(57)^{2}\end{array}$ & {$[6.90,8.24]$} \\
\hline Lab PK & $7.64 \pm 0.16$ & NA & $\begin{array}{c}7.75 \pm 0.21 \\
(52)\end{array}$ & {$[7.25,8.25]$} \\
\hline $\begin{array}{l}\text { Total organic } \\
\text { carbon (ppb) }\end{array}$ & $586 \pm 347$ & NA & $\begin{array}{c}519 \pm 367^{c} \\
(62)\end{array}$ & $\begin{array}{l}2,610 \\
1,610^{c}\end{array}$ \\
\hline
\end{tabular}


Summary of Provisional Hanford Site Groundwater Background Values ${ }^{\text {a }}$ (Johnson, 1993b). (3 sheets)

\begin{tabular}{|c|c|c|c|c|}
\hline $\begin{array}{c}\text { Constituent } \\
\text { (concentration) }\end{array}$ & PNL Results & $\begin{array}{l}\text { USGS Results } \\
\text { (sample size) }\end{array}$ & $\begin{array}{l}\text { WHC Unconfined } \\
\text { (sample size) }\end{array}$ & $\begin{array}{l}\text { WHC Provisional } \\
\text { Threshold Values }\end{array}$ \\
\hline $\begin{array}{l}\text { Field conductivity } \\
(\mu \mathrm{mhos} / \mathrm{cm})\end{array}$ & NA & NA & $\begin{array}{l}344 \pm 83 \\
\text { (22) }\end{array}$ & 539 \\
\hline $\begin{array}{l}\text { Lab conductivity } \\
(\mu \mathrm{mhos} / \mathrm{cm})\end{array}$ & $380 \pm 82$ & NA & $\begin{array}{c}332 \pm 93 \\
(36)\end{array}$ & 530 \\
\hline $\begin{array}{l}\text { Total organic } \\
\text { halogen, lower } \\
\text { detection limit } \\
\text { (ppb) }\end{array}$ & $\overline{N A}$ & MA & $\begin{array}{l}<20^{c} \\
(14)\end{array}$ & $\begin{array}{l}60.8 \\
37.6^{\mathrm{C}}\end{array}$ \\
\hline $\begin{array}{l}\text { Total carbon } \\
\text { (ppb) }\end{array}$ & NA & NA & $\begin{array}{c}31,772 \pm 7,022 \\
(48)\end{array}$ & 50,100 \\
\hline $\begin{array}{l}\text { Gross alpha } \\
(\mathrm{pCi} / L)\end{array}$ & $2.5 \pm 1.4$ & NA & $\begin{array}{c}2.5 \pm 1.5^{c} \\
(36)^{c}\end{array}$ & $5.79^{\circ} \mathrm{c}$ \\
\hline $\begin{array}{l}\text { Gross beta } \\
\text { (pCi/L) }\end{array}$ & $19 \pm 12$ & NA & $\begin{array}{l}7.1 \pm 2.6^{c} \\
(44)\end{array}$ & $\begin{array}{l}35.5 \\
12.62^{c}\end{array}$ \\
\hline $\begin{array}{l}\text { Radium } \\
(p C i / L)\end{array}$ & $<0.2$ & NA & $\begin{array}{l}\text { ND } \\
(10)\end{array}$ & 0.23 \\
\hline
\end{tabular}

Note: Johnson, V. G., 1993, Westinghouse Hanford Company Operational Groundwater Status Report, WHC-EP-0595, West inghouse Hanford Company, Richland, Washington.

Source: From Tables 5.9 and 5-11 CDOE-RL, 1992, Hanford Site Groundwater Background,

b DOE/RL-92-23, U.S. Department of Energy, Richland Operations Office, Richland, Washington).

b Results shown are mean $z$ one standard deviation.

c Potential outlier observation(s) were removed.

$N A=$ not available.

$N C=$ not calculated

ND $=$ not detected.

PNL = Pacific Northwest Laboratory.

$\mathrm{ppb}=$ parts per billion.

USGS = United States Geological Survey.

WHC = Westinghouse Hanford Company. 
WHC-EP-0690

APPENDIX A-2

GROUNDWATER DATA FOR SELECTED

UPGRADIENT WELLS (NEAR THE

216-S-26 CRIB LOCATION) 
忍

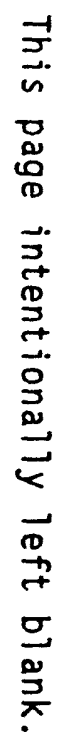

종
1
m
웅
0
0 
Analytical results for upgradient monitoring wells near the 216-5-26 Crib location are listed by well number, constituent name, and sampling date on pages A2-2 through A2-30. Results are reported in the Hanford Environmental Information System (HEIS) database, which was queried for results in July of 1993. The time period covered by these results goes from January of 1986 through July of 1993.

\section{Qualifiers}

Qualifiers concerning the data are indicated with a letter code in the seventh column and are defined as follows:

B - Blank assoiated with analyte is elevated in concentration

D - Sample was diluted before analysis

E - Concentration is out of instrument calibration range

$J$ - Concentration is estimated

$U$ - Analyte concentration is below contract required quantification limit

$H$ - Laboratory holding time exceeded

$R$ - Suspect data; currently under review

Q - Result associated with suspect quality control data

P - Potential problem.

It should also be noted that not all of the data in the table were reviewed at the time this report was prepared. Thus, some unflagged "suspect" data may exist in the table.

\section{Significant Figures}

No more than three significant figures are justified; any additional places are database format related.

\section{Natural Background Reference Levels}

A summary of provisional background concentrations for naturally occuring constituents is provided on pages A2-31 through A2-33. Monitoring results listed on pages A2-2 through A2-30 can be compared with either the average natural background concentrations or with the provisional threshold values (columns 4 and 5, respectively, pages A2-31 through A2-33). The latter represent the upper range of naturally occuring concentrations that are considered likely to occur at the Hanford Site based on currently available data. A major sampling effort is underway to better define both soil and groundwater natural background for the Hanford Site. 


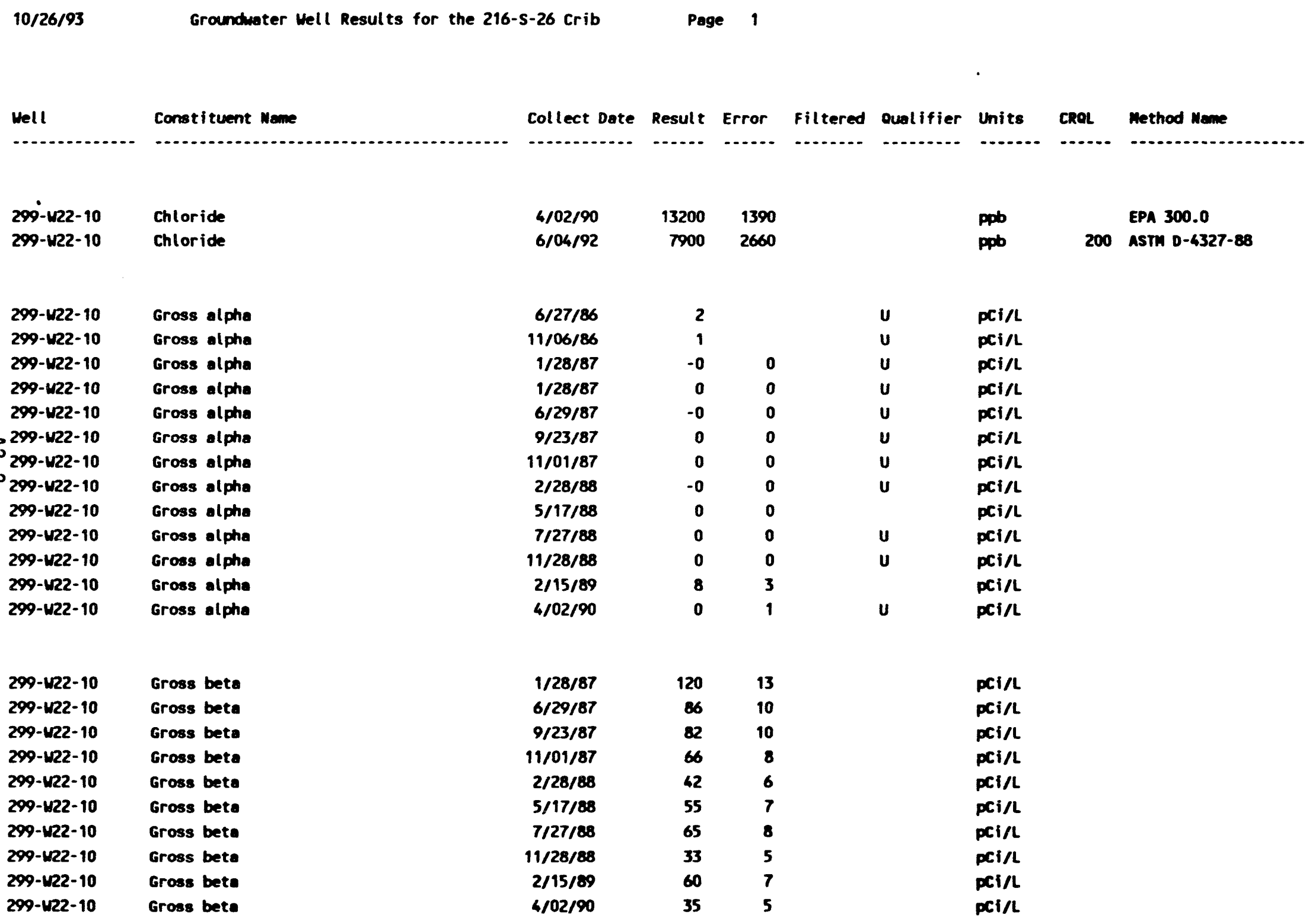


well

Constituent Mame

299-W22-10

Mitrate

$299-122-10$

Nitrate

299- W22-10

$299-122-10$

299-122-10

Specific conductance

specific conductence

Specific conductance

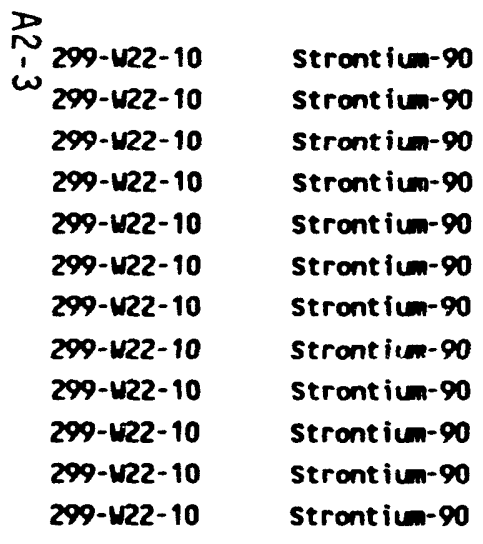

\section{9-422-10 \\ Sulfate}

299-122-10

Sulfate

299-122-10
Collect Date Result Error

Filtered Qualifier Units

CROL

Method Name

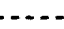

........

$4 / 02 / 90 \quad 500$

$6 / 04 / 92$

$5100 \quad 2870$

$4 / 02 / 90$

$4 / 02 / 90$

$6 / 04 / 92$

177

194
385

18

\section{$6 / 27 / 86$}

$1 / 28 / 87$

$1 / 28 / 87$

$6 / 29 / 87$

$9 / 23 / 87$

$11 / 01 / 87$

2/28/88

$5 / 17 / 88$

$7 / 27 / 88$

$11 / 28 / 88$

$2 / 15 / 89$

$4 / 02 / 90$

$4 / 02 / 90$

$6 / 04 / 92$

500

15000

67

$1 / 28 / 87$
483000

36
62
94
41
28
33
26
20
25
17
30
13

u

ppob

unhos

unhos

unhos

pCi/L

pCi/L

pCi/L

pCi/L

PCi/L

pCi/L

$\mathrm{PCi} / \mathrm{L}$

pCi/L

$\mathrm{pCi} / \mathrm{L}$

pCi/L

$\mathrm{pCi} / \mathrm{L}$

pCi/L

ppb

ppb

500 ASTM D-4327-88
EPA 300.0

200 ASTM D-4327-88

ASTM D-1125-A

1 Prabe, Conductivity

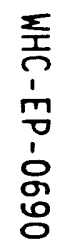


10/26/93 Grouncwater Well Results for the 216-5-26 Crib Page 3

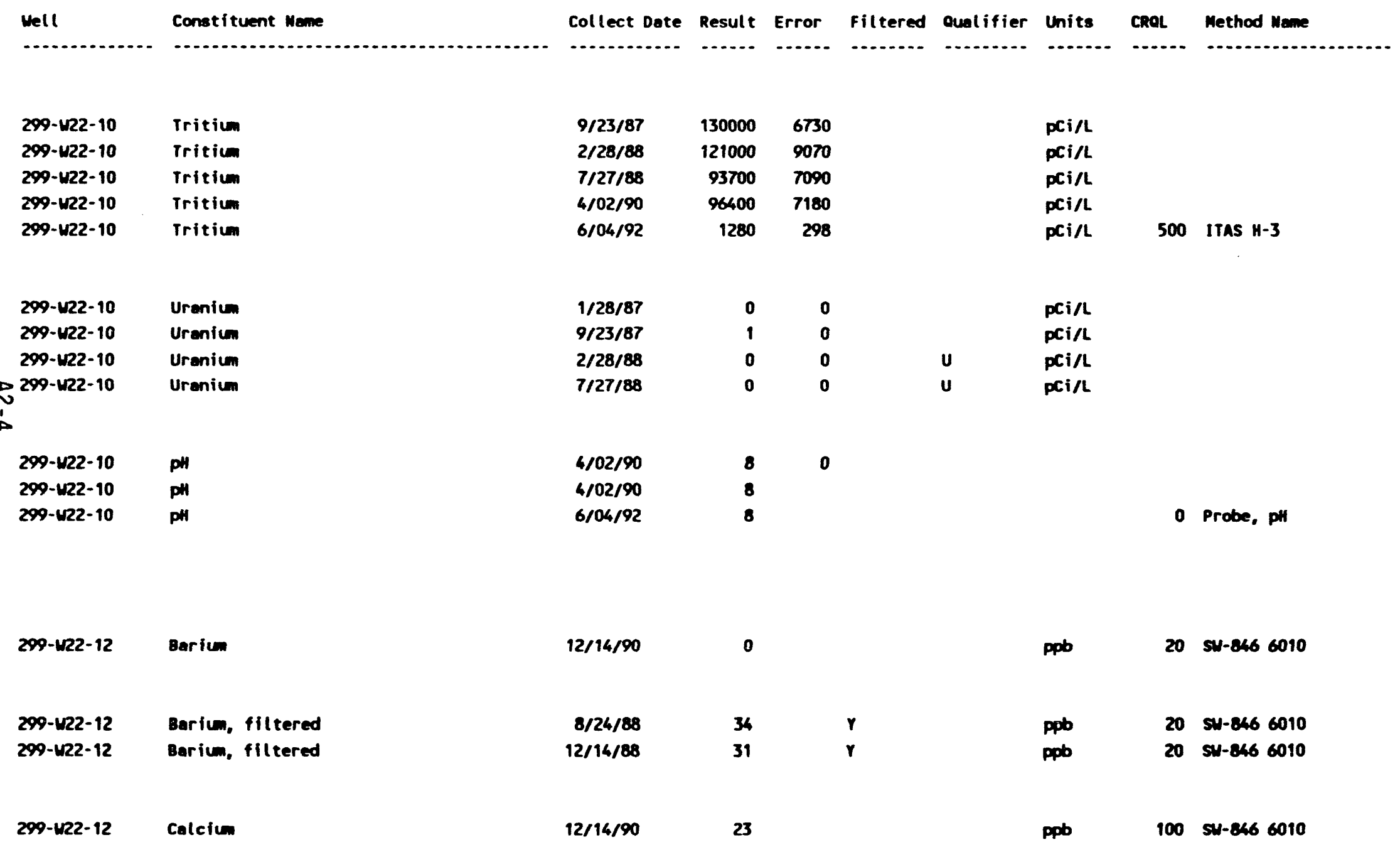


Well

\section{Constituent Mame}

299-422-12

$299-422-12$

\section{Calciun, filtered}

colciun, filtered

Chloride

Chloride

Chloride

chloride

Chloride

Chloride

chloride

D 299-422-12

in

299-422-12

299-422-12

299-422-12

$299-422-12$

299-w22-12

Gross alpho

Gross alphe

Gross alphe

Gross alpha

Gross alphe

299- $122-12$

299-422-12

299-422-12

$299-122-12$

$299-1222-12$

299- $122-12$

$299-422-12$

$209-122-12$

299-422-12

$299-122-12$
Gross beta

Gross beta

Gross bete

Gross bete

Gross bete

Gross bete

Gross beto

Gross bets

Gross bete

Gross beta

Collect Date Result Error Filtered oualifier Units

.......-

...

$\begin{array}{rr}8 / 24 / 88 & 25 \\ 12 / 14 / 88 & 2800 \\ & \\ 3 / 16 / 87 & 7360 \\ 5 / 28 / 87 & 6160 \\ 8 / 18 / 87 & 62 \\ 8 / 24 / 88 & 6180 \\ 12 / 14 / 88 & 5900 \\ 5 / 17 / 90 & 5600 \\ 6 / 19 / 92 & 3800\end{array}$

\section{0}

28000

$r$

ppb

ppob

100 SW-846 6010

$3 / 16 / 87$

$5 / 28 / 87$

$8 / 18 / 87$

$5 / 17 / 90$

$5 / 17 / 90$

$3 / 04 / 86$
$6 / 30 / 86$
$1 / 19 / 87$
$3 / 16 / 87$
$5 / 28 / 87$
$5 / 28 / 87$
$8 / 18 / 87$
$8 / 18 / 87$
$11 / 01 / 87$

2/22/88

$\begin{array}{rr}7360 & \\ 6160 & \\ 6250 & \\ 6180 & \\ 5900 & \\ 5600 & 570 \\ 3800 & 1280\end{array}$

$\begin{array}{ll}\text { ppb } & \text { EPA } 300.0 \\ \text { ppb } & \text { EPA } 300.0 \\ \text { ppb } & \text { EPA } 300.0 \\ \text { ppb } & \text { EPA } 300.0 \\ \text { ppb } & \text { EPA } 300.0 \\ \text { ppb } & \text { EPA } 300.0 \\ \text { ppb } & 200 \text { ASTM D-4327-88 }\end{array}$

PCi/L

pCi/L

PCi/L

pCi/L

pCi/L

pCi/L

pci/l

pCi/L

$\mathrm{pCi} / \mathrm{L}$

$\mathrm{pCI} / \mathrm{L}$

pCi/L

PCi/L

PCi/L

pCill

PCI/L 
Well

Constituent Wame

299-w22-12

299-w22-12

299-w22-12

\section{Gross bete}

Gross bete

Gross beta

\section{9-W22-12}

299-422-12

$299-422-12$

299- $122-12$

299- $122-12$

$\rightarrow$ 299-w22-12

? 299-122-12

के 299-w22-12

299-122-12

299-W22-12

299-W22-12

299-422-12

299-422-12

299-w22-12

299-422-12

299-122-12

Mitrate

Witrate

Mitrate

Nitrate

Mitrate

Mitrate

Mitrate

witrate

Nitrate

Mitrate

Mitrate

Mitrate

Nitrate

Mitrate

Mitrate

Mitrate

299-M22-12 Sodiu

299-122-12

299-122-12
Sodiun, filtered

sodiun, filtered
Collect Date Result Error Filtered Qualifier Units

CROL

Method Mame

Collect Date

$9 / 27 / 88$
$5 / 17 / 90$

$5 / 17 / 90$

$\begin{array}{rr}5 & 2 \\ 10 & 3\end{array}$

PCi/L

pci/l

PCi/L

$\begin{array}{rrr}3 / 04 / 86 & 3 & 1 \\ 6 / 30 / 86 & 5 & 1 \\ 1 / 19 / 87 & & \\ 3 / 16 / 87 & 3920 & \\ 5 / 28 / 87 & 3320 & \\ 5 / 28 / 87 & 3560 & \\ 8 / 18 / 87 & 3040 & \\ 8 / 18 / 87 & 3060 & \\ 11 / 01 / 87 & 2810 & \\ 2 / 22 / 88 & 2770 & \\ 8 / 24 / 88 & 2280 & \\ 9 / 27 / 88 & 2500 & \\ 12 / 14 / 88 & 2400 & \\ 5 / 17 / 90 & 1300 & 148 \\ 5 / 17 / 90 & 1400 & 157 \\ 6 / 19 / 92 & 2000 & 1130\end{array}$

pom

pom

ppob EPA 300.0

ppob EPA 300.0

ppob EPA 300.0

PpD EPA 300.0

Ppp EPA 300.0

pob EPA 300.0

PpDb EPA 300.0

ppo EPA 300.0

ppb

EPA 300.0

EPA 300.0

EPA 300.0

EPA 300.0

EPA 300.0

ppob

ppb

ppob

200 ASTI D-4327-88

$12 / 14 / 90$

18

ppb

300 SH-846 6010

$8 / 24 / 88$

19900

18500
$12 / 14 / 88$

$r$

$300 \quad 5 w-8466010$

300 SW-846 6010 
Well

Constituent Mane

\begin{tabular}{|c|c|}
\hline $299-122-12$ & Specific conductanc \\
\hline $299-1122-12$ & Specific conducten \\
\hline $299-122-12$ & Specific conductan \\
\hline $299-\mathrm{W} 22-12$ & Specific conducten \\
\hline $299-122-12$ & Specific conducten \\
\hline $299-122-12$ & Specific conducten \\
\hline $299-122-12$ & Specific conducte \\
\hline $299-1 / 22-12$ & Specific condu \\
\hline 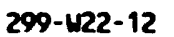 & 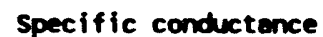 \\
\hline
\end{tabular}

strontium, filtered

strontium, filtered

299-122-12

299-122-12

299-122-12

299-122-12

299-122-12

299-122-12

299-122-12

\begin{tabular}{|c|}
\hline $299-122-12$ \\
\hline $299-122-12$ \\
\hline $299-122-12$ \\
\hline $299-122-12$ \\
\hline $299-422-12$ \\
\hline 299-122-12 \\
\hline
\end{tabular}

strontiun-90

strontium-90

strontiu- 90

strontiun-90

sulfate
Collect Date Result Error

Filtered Qualifier Units

CROL

Method Nane

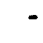

(....... -.....



-......

(n)

ASTM $0-1125-A$

$5 / 17 / 90$

$12 / 14 / 90 \quad 277$ unos

6/19/92 231 mos

1 Probe, Conductivity

$8 / 24 / 88$

$12 / 14 / 88$

136

126

ppb

ppb

SH-846 6010

SU-846 6010

$\begin{array}{rrrrr}3 / 04 / 86 & -0 & 1 & \mathrm{U} & \mathrm{pCi} / \mathrm{L} \\ 6 / 30 / 86 & -0 & 1 & \mathrm{U} & \mathrm{pCi} / \mathrm{L} \\ 1 / 19 / 87 & & & & \mathrm{pCi} / \mathrm{L} \\ 8 / 18 / 87 & 0 & 1 & \mathrm{U} & \mathrm{pCi} / \mathrm{L} \\ 2 / 22 / 88 & 0 & 1 & \mathrm{U} & \mathrm{pCi} / \mathrm{L} \\ 9 / 27 / 88 & -0 & 1 & \mathrm{U} & \mathrm{pCi} / \mathrm{L} \\ 12 / 14 / 90 & 0 & 1 & \mathrm{u} & \mathrm{pCi} / \mathrm{L}\end{array}$

5 ITAS Sr-90

\begin{tabular}{|c|c|c|}
\hline $3 / 16 / 87$ & 20600 & \\
\hline $5 / 28 / 87$ & 19900 & \\
\hline $8 / 18 / 87$ & 18900 & \\
\hline $8 / 26 / 88$ & 21600 & \\
\hline $12 / 14 / 88$ & 18500 & \\
\hline $5 / 17 / 90$ & 18000 & 1800 \\
\hline
\end{tabular}

EPA 300.0

EPA 300.0

EPA $\mathbf{3 0 0 . 0}$

EPA 300.0

EPA 300.0

EPA 300.0
$5 / 17 / 90$ ppob

ppo 
Well

Constituent Neme

Sulfate

$299-122-12$

299-122-12

sulfate

299-422-12

299-122-12

$299-122-12$

299-w22-12

$299-122-12$

299-122-12

299-U22-12

i 299-w22-12

$\infty$ 299-422-12

299-N22-12

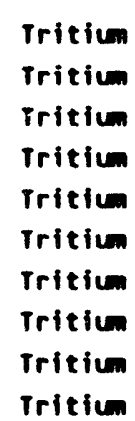

299-122-12

299-422-12

299-M22-12

299-422-12

Uraniun

Urenium

Urenium

Uranium

299-122-12 299-122-12

\section{Venediun, filtered}

Venediun, filtered

zinc

299-122-12

zinc, filtered

299-122-12
Collect Date Result Error

Filtered

oualifier Units

Crol Method Mane

C......

ppo

ppb 500 ASTr $0-4327-88$

$5 / 17 / 90$

$\begin{array}{rr}18300 & 1830 \\ 15000 & 14500\end{array}$

$15000 \quad 14500$

\section{$3 / 04 / 86$}

$6 / 30 / 86$

$1 / 19 / 87$

$5 / 28 / 87$

$8 / 18 / 87$

$11 / 01 / 87$

$2 / 22 / 88$

$9 / 27 / 88$

$12 / 14 / 90$

$6 / 19 / 92$

\begin{tabular}{rr}
76100 & 5430 \\
519 & 1700 \\
& \\
17900 & 2200 \\
33600 & 1900 \\
26900 & 1580 \\
25200 & 2130 \\
20100 & 1750 \\
14000 & 1167 \\
97100 & 7239 \\
\hline
\end{tabular}

$r$

ppo

500 ITAS $M-3$

500 ITAS $\mathrm{H}-3$
pCi/l

pcill

pCi/L

ppo

1 ITAS Gross U

ppb $\quad 30 \quad \mathrm{sW}-8466010$

pab $30 \quad$ su-846 6010

10 SN-846 6010

pob

$105 N-8466010$
$8 / 18 / 87$

$2 / 22 / 88$

9/27/88

$12 / 14 / 90$

$8 / 24 / 88$

$12 / 14 / 88$

\section{5}

19

$12 / 16 / 90$

$8 / 24 / 80$

$\begin{array}{ll}1 & 0 \\ 1 & 0 \\ 1 & 0 \\ 1 & 0\end{array}$

0 
well Constituent Mame

299-122-12 zinc, fittered

299-122-12

299-422-12

299-122-12

299- M22-12

299- w22-12

299- 1122-12

299-122-12

古299-122-12

iv 299-WR2-12

299-122-12

299-122-12

299-422-12

299-422-12

PH
PH
PH
PH
PH
PH
PH
PH
PH
PH
PH
PH
PH

299-122-20

299- W22-20

299-422-20

Bariun

Barium

Berium

299-122-20

299-422-20

299-122-20

299-122-20

299-122-20

\author{
Bariun, filtered \\ Bariun, filtered \\ Bariun, filtered \\ Borín, filtered \\ Bariun, filtered
}

Collect Date Result Error



$12 / 14 / 88$

45

$\mathbf{r}$

ppb

10 SW-846 6010

$\begin{array}{rr}3 / 16 / 87 & 8 \\ 3 / 16 / 87 & 8 \\ 5 / 28 / 87 & 8 \\ 5 / 28 / 87 & 8 \\ 8 / 18 / 87 & 6 \\ 8 / 18 / 87 & 8 \\ 8 / 24 / 88 & 8 \\ 8 / 24 / 88 & 8 \\ 12 / 14 / 88 & 8 \\ 5 / 17 / 90 & 8 \\ 5 / 17 / 90 & 8 \\ 12 / 14 / 90 & 8 \\ 6 / 19 / 92 & 8\end{array}$

0

8 o Probe, pil

\begin{tabular}{|c|c|c|}
\hline ppob & 20 & $\mathrm{SN}-8466010$ \\
\hline ppob & 20 & $5 N-8466010$ \\
\hline ppob & 20 & $5 N-8466010$ \\
\hline ppob & 20 & $5 \%-2466010$ \\
\hline ppb & 20 & $S W-8466010$ \\
\hline ppob & 20 & $S N-8466010$ \\
\hline ppt & 20 & $s N-8466010$ \\
\hline
\end{tabular}


Well

Constituent Mane

\section{9- $122-20$}

299-1222-20

299- $122-20$

Calcium
Calcium
Calcium

299-122-20

299- $122-20$

299- N22-20

㣽 299-w22-20

'299-422-20

\begin{tabular}{|c|c|}
\hline $299-1222-20$ & Chloride \\
\hline $299-W 22-20$ & Chloride \\
\hline $299-122-20$ & Chloride \\
\hline 299-W22-20 & Chloride \\
\hline $299-122-20$ & Chloride \\
\hline $299-122-20$ & Chloride \\
\hline $299-122-20$ & Chloride \\
\hline $299-122-20$ & Chloride \\
\hline $299-\operatorname{VR2}-20$ & Chloride \\
\hline $299-122-20$ & Chloride \\
\hline $299-1122-20$ & Chloride \\
\hline $299-w 22-20$ & Chloride \\
\hline $299-122-20$ & Chloride \\
\hline $299-122-20$ & Chloride \\
\hline $299-122-20$ & Chloride \\
\hline
\end{tabular}

Collect Date Result Error $-$

Calciun, filtered

Calciun, filtered

Calciun, filtered

Calcium, filtered

calcium, filtered

$\begin{array}{rr}3 / 02 / 88 & 88200 \\ 10 / 03 / 91 & 83000 \\ 1 / 07 / 92 & 92000\end{array}$

88200

92000

$\begin{array}{rrrr}3 / 02 / 88 & 89200 & & r \\ 8 / 24 / 88 & 89400 & & r \\ 12 / 14 / 88 & 97600 & & r \\ 2 / 21 / 90 & 76300 & 9790 & r \\ 1 / 07 / 92 & 88000 & & r\end{array}$

$5 / 28 / 87$

$8 / 18 / 87$

$12 / 09 / 87$

$3 / 02 / 88$

$8 / 24 / 88$

$12 / 14 / 88$

$2 / 21 / 90$

$1 / 18 / 91$

$4 / 01 / 91$

$6 / 18 / 91$

$9 / 04 / 91$

$12 / 04 / 91$

$1 / 07 / 92$

$5 / 12 / 92$

$8 / 19 / 92$
88000

\section{0}

30500

44900

33200

26700

25900

25800

2650

22
21

24

25

30000

24000

26000
Filtered Qualifier Units

CROL

Method Manse 
Nell

Constituent Hame

Gross alphs

$299-422-20$

299-W22-20

299-W22-20

299-W22-20

299-W22-20

299-1222-20

299-W22-20

299-WR2-20

299-122-20

299-422-20

D7 299-122-20

' 299-M22-20

- 299-122-20

299-122-20

299-122-20

299-122-20

299-422-20

299-122-20

299-M22-20

299- M22-20

299-122-20

$299-122-20$

299-122-20

299-422-20

299-122-20

299-122-20

299-122-20

299-122-20
Gross alpha

Gross olpha

Gross olphe

Gross alphe

Gross alphe

Gross alpho

Grose alpho

Gross alphe

Gross alpho

Gross alphe

Gross alpha

Gross olpha

Gross alpho

Gross al pha

Gross beta

Gross beta

Gross beta

Gross bete

Gross beta

Gross bete

Gross bete

Gross beta

Gross bete

Gross bete

Gross bete

Groas beta

Gross beta
Collect Date Result Error Filtered Qublifier Units

$\mathrm{CROL}$

Method Mame
4 sU-846 9310, Alpha
4 sU-846 9310, Alphe
4 sU-846 9310, Alphe
4 sU-846 9310, Alphe
4 sU-846 9310, Alphe
4 sU-846 9310, Alphe
4 sU-846 9310, Alpha
4 su-846 9310, Alphe
4 su-846 9310, Alphe
4 su-846 9310, Alphe
4 su-846 9310, Alphe

PCi/L

PCi/L

PCi/L

PCi/L

pCi/l

pCi/L

pci/l

pCill

PCi/L

PCi/L

PCi/L

PCi/L

PCi/L 
Well

$\begin{array}{ll}299-\mathrm{W} 22-20 & \text { Gross beta } \\ 299-\mathrm{W} 2-20 & \text { Gross beta } \\ 299-\mathrm{W22}-20 & \text { Gross beta } \\ 299-\mathrm{W22}-20 & \text { Gross beta } \\ 299-\mathrm{W} 22-20 & \text { Gross beta } \\ 299-\mathrm{W} 22-20 & \text { Gross beta } \\ 299-\mathrm{W} 22-20 & \text { Gross beta } \\ 299-\mathrm{W} 22-20 & \text { Gross beta } \\ 299-\mathrm{W} 22-20 & \text { Gross beta } \\ 299-\mathrm{W} 22-20 & \text { Gross beta } \\ 299-\mathrm{W} 2-20 & \text { Gross beta } \\ 299-\mathrm{W} 22-20 & \text { Gross beta }\end{array}$

299-122-20

299- N22-20

299-w22- 20

299-w22-20

299-422- 20

299-W22-20

299-w22-20

299-w22-20

299- v22-20

299- v22-20

299- M22-20

299-w22-20

399-422-20

299-122-20

299- M22-20

299- -122-20
Constituent Mame

Gross beta
Collect Date Result Error Filtered Oualifier Units

CROL

Method Mane

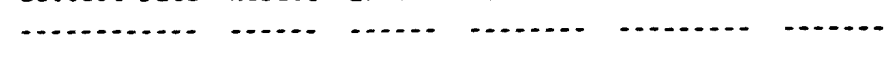

\begin{tabular}{|c|c|c|c|c|c|c|c|}
\hline $2 / 21 / 90$ & 20 & 4 & & $\mathrm{pCi} / \mathrm{L}$ & & & \\
\hline $8 / 06 / 90$ & 21 & 4 & & pCi/L & 8 & SW-846 9310, & Beta \\
\hline $10 / 16 / 90$ & 35 & 5 & & $\mathrm{pCi} / \mathrm{L}$ & 8 & SW-846 9310, & Beta \\
\hline $1 / 18 / 91$ & 51 & 7 & & pCi/L & 8 & SW-846 9310, & Beta \\
\hline $4 / 01 / 91$ & 30 & 5 & & $\mathrm{pCi} / \mathrm{L}$ & 8 & SW-846 9310 , & Beta \\
\hline $6 / 18 / 91$ & -6 & 3 & $u$ & pCi/L & 8 & SH-846 9310, & Beta \\
\hline $9 / 04 / 91$ & 37 & 6 & & pCi/l & 8 & SW-846 9310, & Beta \\
\hline $10 / 03 / 91$ & 36 & 5 & & pCi/L & 8 & SW-846 9310, & Beta \\
\hline $12 / 04 / 91$ & 26 & 4 & & $\mathrm{pCi} / \mathrm{L}$ & 8 & SH-846 9310, & Beta \\
\hline $5 / 12 / 92$ & 66 & 14 & & pCi/l & 8 & SW-846 9310, & Beta \\
\hline $8 / 19 / 92$ & 34 & 5 & & pCi/L & 8 & SH-846 9310 , & Beta \\
\hline $11 / 17 / 92$ & 38 & 6 & & pCi/L & 8 & SW-846 9310, & Beta \\
\hline
\end{tabular}

\begin{tabular}{|c|c|c|c|c|c|c|}
\hline Witrote & $5 / 28 / 87$ & 123000 & & ppob & & EPA 300.0 \\
\hline Mitrate & $8 / 18 / 87$ & 131000 & & ppob & & EPA 300.0 \\
\hline Witrate & $12 / 09 / 87$ & 131000 & & ppob & & EPA 300.0 \\
\hline Witrate & $2 / 22 / 88$ & 122000 & & ppb & & EPA 300.0 \\
\hline Mitrate & $3 / 02 / 88$ & 124000 & & ppb & & EPA 300.0 \\
\hline Nitrate & $8 / 24 / 88$ & 199000 & & ppob & & EPA 300.0 \\
\hline Mitrate & $9 / 28 / 88$ & 132000 & & ppb & & EPA 300.0 \\
\hline Witrate & $12 / 14 / 88$ & 140000 & & ppb & & EPA 300.0 \\
\hline Witrate & $2 / 21 / 90$ & 142000 & 14300 & ppb & & EPA 300.0 \\
\hline Nitrate & $1 / 18 / 91$ & 122 & & ppon & & PNL Anions \\
\hline Witrate & 4/01/91 & 132 & & ppom & & PNL Anions \\
\hline Mitrate & $6 / 18 / 91$ & 136 & & ppm & & PNL Anions \\
\hline Witrate & $9 / 04 / 91$ & 136 & & ppon & & PNL Anions \\
\hline Witrate & $10 / 03 / 91$ & 145000 & & ppob & 200 & EPA Method 300.0 \\
\hline Mitrate & $12 / 06 / 91$ & 28000 & 15800 & ppob & 200 & ASTM D-4327-88 \\
\hline Witrate & $1 / 07 / 92$ & 110000 & 61900 & ppob & 200 & ASTM $0-4327-88$ \\
\hline
\end{tabular}


Hell

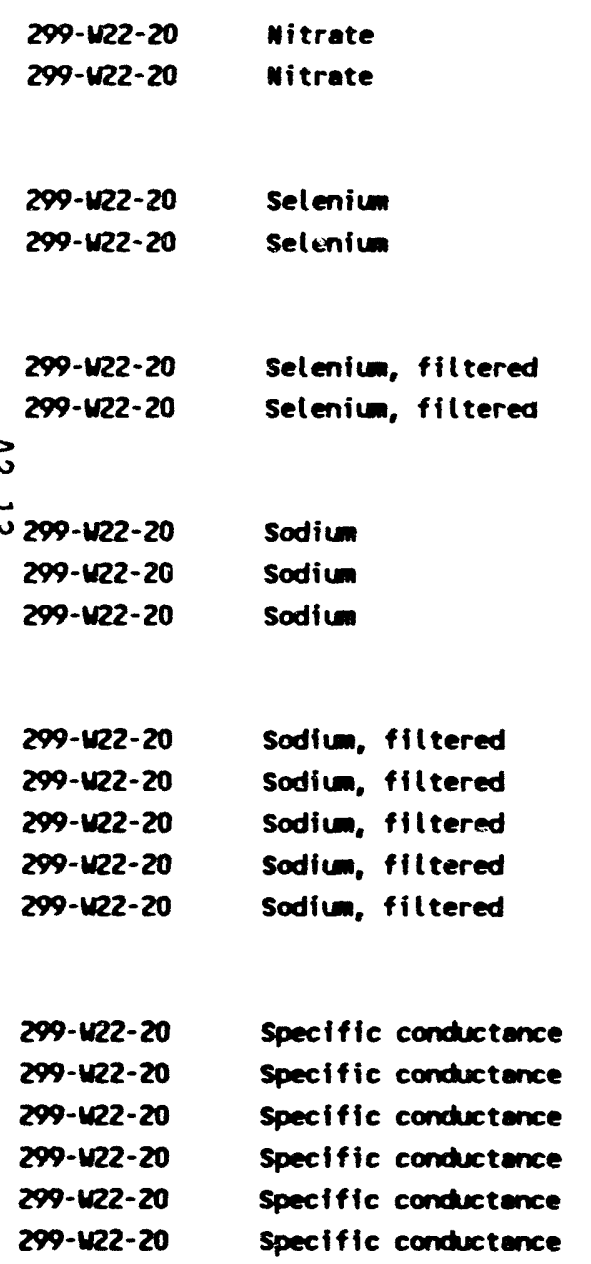

Collect Date

Result

Error

Filtered



$5 / 12 / 92$

$8 / 19 / 92$

$100000 \quad 56300$

$120000 \quad 67500$

$3 / 02 / 88$

$1 / 07 / 92$

14

10

$3 / 02 / 88$

1/07/92

8

8
10

$3 / 02 / 88$

10/03/91

$1 / 07 / 92$

54600

52000

56000

$3 / 02 / 88$

$8 / 24 / 88$

$12 / 14 / 88$

2/21/90

$1 / 07 / 92$

53500
55600
48900
53400
55000

$5 / 28 / 87$

$8 / 18 / 87$

$12 / 09 / 87$

$3 / 02 / 88$

$8 / 24 / 88$

$12 / 14 / 88$

$\begin{array}{lll}\text { ppb } & 200 & \text { ASTM } 0-4327-80 \\ \text { ppob } & 200 & \text { ASTM } 0-4327-88\end{array}$

ppob 200 ASTM D-4327-88

ppo

ppo

$10 \mathrm{sW}-8467740$

ppb $10 \mathrm{sU}-8467740$

ppb 10 SU-846 740

ppob

ppb $300 \quad$ SW-846 6010

ppb 300 SU-846 6010

ppb $\quad 300 \quad 5 H-8466010$

ppo $\quad 300 \quad 54-8466010$

ppb $\quad 300$ SU-846 6010

ppb $300 \quad 5 N-8466010$

ppb $300 \quad \mathrm{SH}-8466010$

unos

whos

unhos

whos

whos

chinos 
Wel

Constituent Mame

Specific conductance

Specific conductence

Specific conductence

specific conductence

Specific conductence

specific conductance

specific conductence

Specific conductence

Specific conductence

specific conductence

Specific conductence

specific conductence

specific conductence

Specific conductance

strontiven

strontiun, filtered

strontiun, filtered

strontiun, filtered

strontiu, filtered

299-128

299-122-20

$\begin{array}{ll}299-122-20 & \text { strontium-90 } \\ 299-122-20 & \text { strontiun-90 } \\ 299-1122-20 & \text { stront ium-90 } \\ 299-1022-20 & \text { strontiun-90 } \\ 299-1222-20 & \text { strontiun-90 }\end{array}$

Collect Date Result Error

Filtered oulifier Units CROL

Method Mane

Method Me............

ASTM D-1125-A

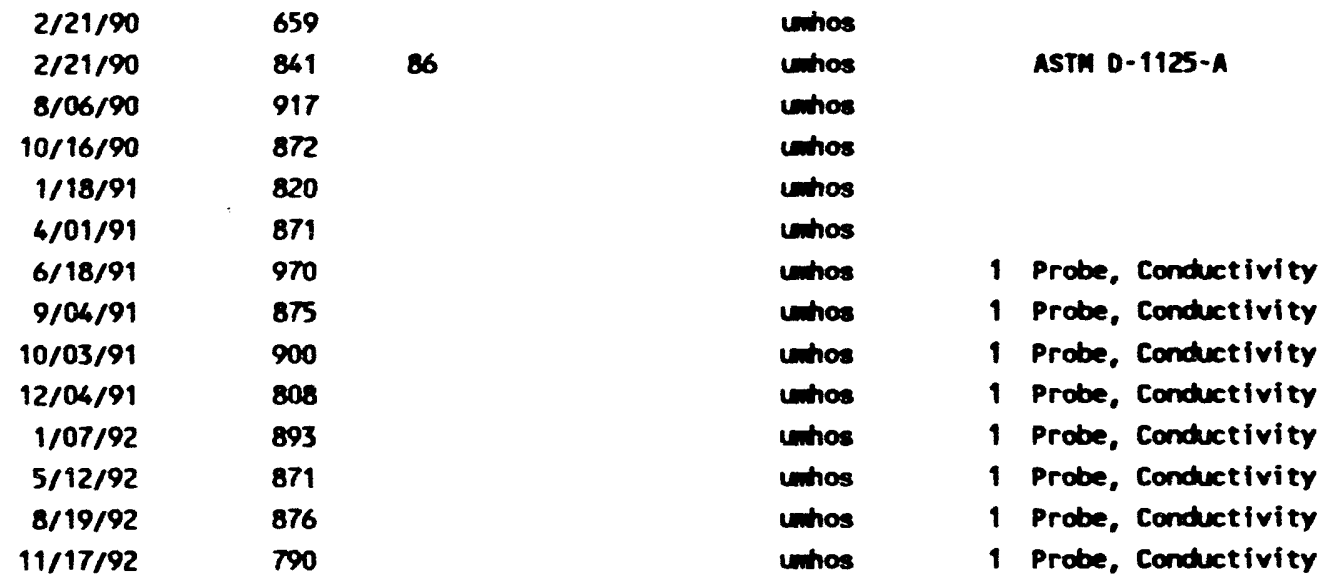

$3 / 02 / 88$

402

ppo

$3 / 02 / 88$

$8 / 24 / 88$

$12 / 14 / 88$

$2 / 21 / 90$

399
420
390
394

$r$
$r$
4
$Y$

ppob

ppob

ppob

ppb

SH-846 6010

SU-846 6010

SU-846 6010
$3 / 04 / 86$

$4 / 29 / 86$

$7 / 31 / 86$

$10 / 30 / 86$

$1 / 26 / 87$
$48 Y$

$\begin{array}{ll}0 & 1 \\ 1 & 1 \\ 0 & 1 \\ 0 & 1 \\ 1 & 1\end{array}$

PCill

DCI/L

PCI/L

peill

pCill 
10/26/93 Groundwater Well Results for the 216-5-26 Crib Page 14

Well

Const I tuent Name

Strontium-90

299-122-20

299-122-20

299-M22-20

$299-422-20$

299-122-20

stront ium-90

stronticu-90

Stront iun-90

strontilen-90

\begin{tabular}{|c|c|}
\hline $299-1022-20$ & Sulfate \\
\hline $299-1022-20$ & Sulfate \\
\hline $299-1022-20$ & Sulfate \\
\hline $299-422-20$ & Sulfate \\
\hline $299-1222-20$ & Sulfate \\
\hline $299-1 / 22-20$ & sulfate \\
\hline $299-422-20$ & Sulfate \\
\hline $299-1222-20$ & sulfate \\
\hline $299-w 22-20$ & Sulfate \\
\hline $299-1222-20$ & sulfate \\
\hline $299-1222-20$ & sulfate \\
\hline $299-1222-20$ & sulfate \\
\hline $299-422-20$ & sulfate \\
\hline $299-622-20$ & sulfote \\
\hline $299-422-20$ & Sul fate \\
\hline $299-422-20$ & Tritium \\
\hline $299-1222-20$ & Trition \\
\hline $299-1122-20$ & Tritiv \\
\hline $299-1222-20$ & Iritiun \\
\hline $299-422-20$ & Tritium \\
\hline $290-1022-20$ & Iritium \\
\hline
\end{tabular}

Collect Date Result Error

-

$8 / 18 / 87$
$2 / 22 / 88$
$9 / 28 / 88$
$2 / 21 / 90$
$2 / 21 / 90$

-0
-0
-1
-0
-0

1
1
1
1
1

$\begin{array}{ll}u & \text { pCi/L } \\ u & \text { pCi/L } \\ u & \text { pCi/L } \\ u & \text { pCi/L } \\ u & \text { pCi/L }\end{array}$

$\begin{array}{rrr}5 / 28 / 87 & 149000 & \\ 8 / 18 / 87 & 170000 & \\ 12 / 09 / 87 & 170000 & \\ 3 / 02 / 88 & 147000 & \\ 8 / 24 / 88 & 143000 & \\ 12 / 14 / 88 & 139000 & \\ 2 / 21 / 90 & 151000 & 15100 \\ 1 / 18 / 91 & 157 & \\ 4 / 01 / 91 & 156 & \\ 6 / 18 / 91 & 161 & \\ 9 / 04 / 91 & 155 & \\ 12 / 04 / 91 & 150000 & 145000 \\ 1 / 07 / 92 & 140000 & 135000 \\ 5 / 12 / 92 & 130000 & 125000 \\ 8 / 19 / 92 & 150000 & 145000\end{array}$

$3 / 04 / 86$

$4 / 29 / 86$

$7 / 31 / 86$

$10 / 30 / 86$

$1 / 26 / 87$

$5 / 28 / 87$

$\begin{array}{ll}724000 & 37600 \\ 747000 & 36900 \\ 605000 & 32300 \\ 362000 & 20100 \\ 268000 & 14000 \\ 262000 & 14300\end{array}$

EPA 300.0

$\begin{array}{ll}\text { ppb } & \text { EPA } 300.0 \\ \text { ppb } & \text { EPA } 300.0\end{array}$

Ppob EPA 300.0

ppb EPA 300.0

ppo EPA 300.0

ppb EPA 300.0

EPA 300.0

Ppon PNL Anione

ppon PILL Anions

ppon PAl Anions

Pp. PNL Anione

ppb 500 ASTM D-4327-83

ppb $\quad 500$ ASTM D-4327-80

ppb 500 ASTM D-4327-80

ppb 500 ASTM D-4327-80

pCi/L

pci/l

PCi/L

pci/l

pCi/L

pci/l 
well

Constituent wame

\section{Tritiun}

Tritium

$299-422-20$

299-422-20

299- $122-20$

299- $122-20$

$299-122-20$

299-122-20

$299-1122-20$

299-122-20

299-422-20

忿299-M22-20

$\therefore 299-122-20$

ने 299-122-20

299-122-20

$299-122-20$

299- $122-20$

\section{Iritiun}

Tritium

Tritiun

Tritiun

Tritium

Tritium

Tritium

iritiun

Tritiun

Tritium

Iritium

Tritiun

Trition

Trition

299-122-20

299-1222-20

299-422-20

299-422-20

299-422-20

299-422-20

299-422-20

$299-1022-20$

299-422-20

299-422-20

299-1022-20

299-122-20



Uraniun

Ureniun

Ureniun

renica

Uranica

Ureniva

Ureniun
Collect Date Result Error Filtered Oulifier Units

CROL

Method Mame

500 ITAS $H-3$

500 ITAS H-3

500 ITAS $H-3$

500 ITAS $H-3$

500 ITAS $H-3$

500 ITAS $\mathrm{H}-3$

500 ITAS H-3

500 ITAS $H-3$

500 ITAS $H-3$

500 ITAS H-3

500 ITAS $H-3$

pCi/L

pCill

pCi/L

PCi/L

$\mathrm{PCi} / \mathrm{L}$

$\mathrm{PCi} / \mathrm{L}$

ppob

ppob

ppb

ppob

ppob

ppob
1 ITAS Gross U
1 ITAS Groas U
1 ITAS Groas U
1 ITAS Groas U
1 ITAS Grose U
1 ITAS Gross U 





Well

$\begin{array}{ll}299-122-20 & \text { PH } \\ 299-1222-20 & \text { PH } \\ 299-122-20 & \text { PH } \\ 299-122-20 & \text { PH } \\ 299-1122-20 & \text { PH } \\ 299-1122-20 & \text { PH } \\ 299-122-20 & \text { PH } \\ 299-122-20 & \text { PH } \\ 299-122-20 & \text { PH } \\ 299-1222-20 & \text { PH } \\ 299-1122-20 & \text { PH } \\ 299-122-20 & \text { PH } \\ 299-122-20 & \text { PH } \\ 299-122-20 & \text { PH } \\ 299-122-20 & \text { PH } \\ 299-1122-20 & \text { PH } \\ 299-122-20 & \text { PH } \\ 299-122-20 & \text { PH } \\ 299-122-20 & \text { PH } \\ 299-1122-20 & \text { PH } \\ 299-122-20 & \text { PH } \\ 299-122-20 & \text { PH } \\ 299-122-20 & \text { PH }\end{array}$

299-122-21
Constituent Mame

Int

pil

pil

pH

PHI

PH

PH

ph

PHI

PH

pen

PH

pen

pil

PH

Collect Date Result Error

Filtered ouslifier Units

Crol

Method wame
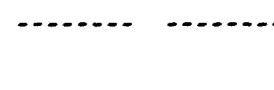

nechod whene

$\begin{array}{rr}8 / 18 / 87 & 8 \\ 12 / 09 / 87 & 7 \\ 12 / 09 / 87 & 8 \\ 3 / 02 / 88 & 7 \\ 3 / 02 / 88 & 7 \\ 8 / 24 / 88 & 7 \\ 8 / 24 / 88 & 8 \\ 12 / 14 / 88 & 8 \\ 12 / 14 / 88 & 8 \\ 2 / 21 / 90 & 8 \\ 2 / 21 / 90 & 8 \\ 8 / 06 / 90 & 8 \\ 10 / 16 / 90 & 8 \\ 1 / 18 / 91 & 7 \\ 4 / 01 / 91 & 7 \\ 6 / 18 / 91 & 9 \\ 9 / 04 / 91 & 7 \\ 10 / 03 / 91 & 7 \\ 12 / 04 / 91 & 7 \\ 1 / 07 / 92 & 7 \\ 5 / 12 / 92 & 8 \\ 8 / 19 / 92 & 8 \\ 11 / 17 / 92 & 8\end{array}$

- Probe, pH

- Probe, PAl

o Probe, pit

- Probe, Pll

- Probe, PAl

o Probe, PAl

O Probe, PII

- Probe, pH 


\begin{tabular}{|c|c|c|c|c|c|c|c|c|c|}
\hline 10/26/93 & Groundwater Well Results for the 216- & s-26 Crib & Page & e 18 & & & & & \\
\hline Well & Const ituent Mame & Collect Date & Result & Error & Filtered & Oublifier & Units & Crol & Method Name \\
\hline (n) & (n) & 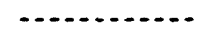 &  & 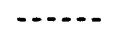 & (........... & (n.............. & -.....- & $\cdots$ & (n) \\
\hline $299-122-21$ & Bariun, filtered & $1 / 09 / 92$ & 27 & 4 & $\mathbf{r}$ & & ppb & 20 & $s N-8466010$ \\
\hline $299-1222-21$ & Colcium & $1 / 09 / 92$ & 32000 & & & & ppob & 100 & $54-8466010$ \\
\hline $299-422-21$ & Calcium, filtered & $1 / 09 / 92$ & 30000 & & $\mathbf{r}$ & & ppb & 100 & $S W-8466010$ \\
\hline $299-122-21$ & Chloride & $1 / 09 / 92$ & 5600 & 1880 & & & ppo & 200 & ASTM D-4327-88 \\
\hline $299-122-21$ & Gross alpha & $3 / 04 / 86$ & 16 & 3 & & & pCi/L & & \\
\hline $299-122-21$ & Gross elpha & $5 / 22 / 86$ & 28 & 5 & & & pCi/l & & \\
\hline $299-122-21$ & Gross alphs & $7 / 30 / 86$ & 23 & 5 & & & pci/l & & \\
\hline $299-122-21$ & Gross elphe & $10 / 30 / 86$ & 23 & 4 & & & PCi/L & & \\
\hline $299-122-21$ & Gross elphe & $1 / 26 / 87$ & 16 & 3 & & & $\mathrm{PCi} / \mathrm{L}$ & & \\
\hline $299-122-21$ & Gross alphe & $5 / 17 / 87$ & 15 & 3 & & & $\mathrm{pCi} / \mathrm{L}$ & & \\
\hline $299-122-21$ & Gross slphs & $9 / 17 / 87$ & 19 & 4 & & & pci/l & & \\
\hline $299-1122-21$ & Gross alphe & $12 / 01 / 87$ & 16 & 3 & & & pci/l & & \\
\hline $299-122-21$ & Gross alphe & $2 / 22 / 88$ & 14 & 3 & & & pcin & & \\
\hline $299-1122-21$ & Gross elphe & $9 / 28 / 88$ & 12 & 3 & & & $\mathrm{pCi} / \mathrm{L}$ & & \\
\hline $299-122-21$ & Gross alphe & $1 / 09 / 92$ & 21 & 6 & & & pci/l & 6 & SH-846 9310, Alpha \\
\hline $299-122-21$ & Gross bete & $3 / 04 / 86$ & 221 & 23 & & & pci/h & & \\
\hline $299-122-21$ & Gross bete & $5 / 22 / 86$ & 181 & 19 & & & $\mathrm{pci} / \mathrm{L}$ & & \\
\hline $299-422-21$ & Gross beta & $7 / 30 / 86$ & 213 & 23 & & & $\mathrm{pci} / \mathrm{L}$ & & \\
\hline $299-122-21$ & Groes beta & $10 / 30 / 86$ & 233 & 24 & & & pci/l & & \\
\hline $299-422-21$ & Grose beta & $1 / 26 / 87$ & 224 & 26 & & & PCi/l & & \\
\hline
\end{tabular}


Well Constituent Mame Collect Date Result Error Filtered Oulifier Units

CroL

Method Mane

$\begin{array}{ll}299-\mathrm{W} 22-21 & \text { Gross beta } \\ 299-\mathrm{W} 22-21 & \text { Gross beta } \\ 299-\mathrm{W} 22-21 & \text { Gross beto } \\ 299-\mathrm{W} 22-21 & \text { Gross beta } \\ 299-\mathrm{W22}-21 & \text { Gross beta } \\ 299-\mathrm{W22}-21 & \text { Gross beta }\end{array}$

\section{9-422-21} 299-1122-21 忍 299-422-21

$\therefore$ 299-N22-21

O 299-122-21

299-122-21

299-422-21

299-422-21

299-422-21

299-1022-21

299-122-21

\section{Mitrate}

Mitrate

Mitrate

Mitrate

Nitrate

witrate

Mitrate

Mitrate

Witrate

Nitrate

Mitrate

299-4R2-21

seleniun

299-122-21

Seleniun, filtered

299-122-21

Sodiu

$\begin{array}{rrr}5 / 17 / 87 & 180 & 19 \\ 9 / 17 / 87 & 198 & 21 \\ 12 / 01 / 87 & 185 & 20 \\ 2 / 22 / 88 & 170 & 18 \\ 9 / 28 / 88 & 164 & 18 \\ 1 / 09 / 92 & 131 & 13\end{array}$

pCi/L

$\mathrm{pCi} / \mathrm{L}$

$\mathrm{pCi} / \mathrm{L}$

pCi/L

PCi/L

$\mathrm{PCI} / \mathrm{L}$

8 su-846 9310, Beta

$3 / 04 / 86$

$5 / 22 / 86$

$7 / 30 / 86$

$10 / 30 / 86$

$1 / 26 / 87$

$5 / 17 / 87$

$9 / 17 / 87$

12/01/87

2/22/88

$9 / 28 / 88$

$1 / 09 / 92$

\begin{tabular}{rr}
13 & 2 \\
13 & 2 \\
14 & 3 \\
13700 & \\
14200 & \\
16000 & \\
13000 & \\
11200 & \\
35300 & \\
12700 & \\
4000 & 2250 \\
\hline
\end{tabular}

pom

ppom

ppom

ppo

ppo

ppob

ppb

ppb

ppo

ppb

EPA 300.0

EPA 300.0

EPA 300.0

EPA 300.0

EPA 300.0

EPA 300.0

EPA 300.0

200 ASTM D-4327-88

$1 / 09 / 92$

10

u

ppo

$10 \mathrm{su}-8467740$

$1 / 09 / 92$

10

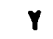

u

$p p b$

$10 \mathrm{su}-846 \pi 70$

$1 / 09 / 92$

28000

SU-846 6010 


\begin{tabular}{|c|c|c|c|c|c|c|c|c|c|}
\hline $10 / 26 / 93$ & Groundwater Mell Results for the 216-5 & s-26 Crib & Pag & 20 & & & & & \\
\hline Mell & Constituent Wame & Collect Date & Result & Error & Filtered & oulifier & Units & CroL & Method Wane \\
\hline - & (n) & (n) & -...... & -...... & (.......... & (.............. & (......... & $\cdots$ & (n) \\
\hline $299-122-21$ & Sodiun, filtered & $1 / 09 / 92$ & 27000 & & $\mathbf{r}$ & & ppb & 300 & SU-846 6010 \\
\hline 299-1222-21 & Specific conductence & $1 / 09 / 92$ & 360 & & & & unhos & 1 & Probe, Conductivity \\
\hline $299-122-21$ & strontiun-90 & $3 / 04 / 86$ & 0 & 1 & & $\mathbf{u}$ & pCi/l & & \\
\hline 299-122-21 & strontiun-90 & $5 / 22 / 86$ & 0 & 1 & & $\mathbf{u}$ & pCi/L & & \\
\hline $299-122-21$ & strontiun-90 & $10 / 30 / 86$ & 0 & 1 & & $\mathbf{u}$ & pci/l & & \\
\hline $299-122-21$ & stront ive-90 & $1 / 26 / 87$ & 1 & 1 & & & pci/L & & \\
\hline 299-422-21 & seronticu-90 & $9 / 17 / 87$ & 1 & 1 & & $\mathbf{u}$ & $\mathrm{pCi} / \mathrm{L}$ & & \\
\hline $299-422-21$ & strontive-90 & $2 / 22 / 88$ & -0 & 1 & & $\mathbf{u}$ & pCi/L & & \\
\hline 299-122-21 & strontiun-90 & $9 / 28 / 88$ & -0 & 1 & & $\mathbf{u}$ & pCi/L & & \\
\hline $299-1222-21$ & Sulfate & $1 / 09 / 92$ & 21000 & 20300 & & & ppob & 500 & ASTM D-4327-88 \\
\hline $299-422-21$ & Tritiu & $1 / 09 / 92$ & 76000 & 5729 & & & pCi/l & 500 & ITAS $n-3$ \\
\hline $299-1422-21$ & Ureniun & $1 / 26 / 87$ & 15 & 6 & & & PCi/L & & \\
\hline 299-122-21 & Uraniun & $5 / 17 / 87$ & 20 & 6 & & & pCi/L & & \\
\hline $299-122-21$ & Uranium & $9 / 17 / 87$ & 20 & 6 & & & pCill & & \\
\hline $299-1122-21$ & Urmilu & $12 / 01 / 87$ & 23 & 7 & & & $\mathrm{PCI} / \mathrm{L}$ & & \\
\hline $299-1222-21$ & Uranium & $1 / 09 / 92$ & 30 & 8 & & & ppb & 1 & ITAS Gross U \\
\hline $299-122-21$ & Venediu & $1 / 09 / 92$ & 38 & 5 & & & ppos & 30 & $s u-8466010$ \\
\hline
\end{tabular}




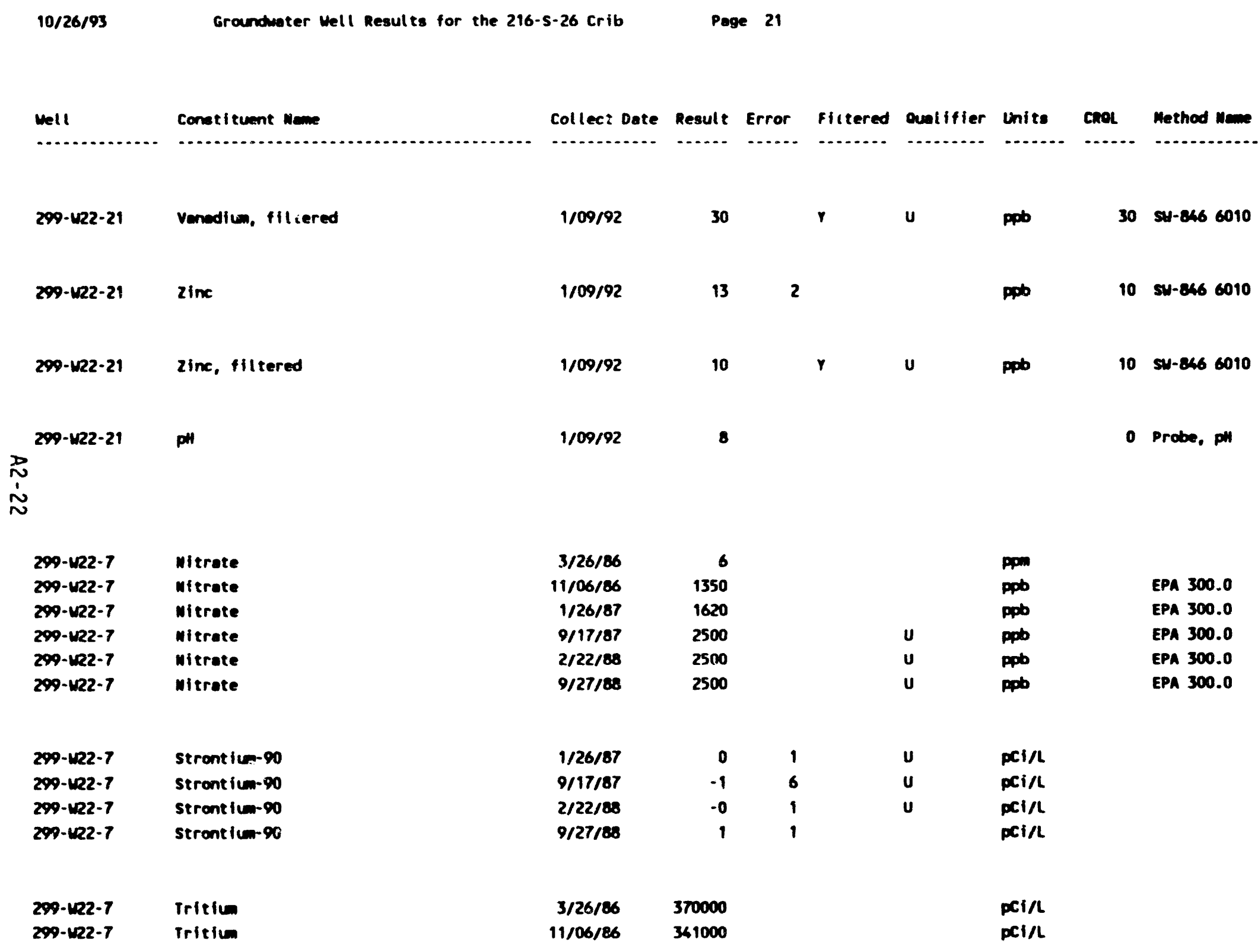


Mell

Constiftuent wose

$\begin{array}{ll}299-122-7 & \text { Iritium } \\ 299-122-7 & \text { Tritiun } \\ 299-122-7 & \text { Tritiun } \\ 299-122-7 & \text { irition }\end{array}$

\section{9-122-7}

299-122-7

Uranicen

Ureniun

299-122-7

Ureniun

$\sum^{2}$

$299-122-7$

Ureniun
Collect Date Result Error



Filtered oulifier Units

Crol

Method Mane

$\begin{array}{llll}1 / 26 / 87 & 412000 & 20800 & \mathrm{pCi} / \mathrm{L} \\ 9 / 17 / 87 & 344000 & 17400 & \mathrm{pCi} / \mathrm{L} \\ 2 / 22 / 80 & 364000 & 26800 & \mathrm{pCi} / \mathrm{L} \\ 9 / 27 / 80 & 335000 & 24700 & \mathrm{pCI} / \mathrm{L}\end{array}$

$\tilde{\omega}$

$\begin{array}{ll}299-123-9 & \text { Chloride } \\ 299-\text { W23-9 } & \text { Chloride } \\ 299-\text { w23-9 } & \text { Chloride }\end{array}$

$4 / 06 / 90$

$11 / 25 / 91$

2700

3300

$4800 \quad 1620$

4/27/92

$1 / 07 / 86$

$2 / 07 / 86$

$3 / 10 / 86$

$4 / 00 / 86$

$5 / 07 / 86$

$6 / 05 / 86$

$7 / 08 / 86$

$9 / 03 / 86$

$11 / 06 / 86$

$11 / 25 / 86$

$12 / 10 / 86$

$\begin{array}{rr}9 & \\ 10 & \\ 14 & 3 \\ 22 & \\ 31 & 6 \\ 22 & \\ 19 & \\ 31 & 6 \\ 38 & \\ 59 & 11 \\ 59 & 11\end{array}$

$\begin{array}{lll}\text { ppob } & & \text { EPA } 300.0 \\ \text { ppob } & 200 & \text { ASTI } 0-4327-88 \\ \text { ppob } & 200 & \text { ASTI } 0-4327-80\end{array}$

pei/l

pCi/L

pei/l

pCi/L

pei/l

DCi/L

PCi/L

pei/l

peirl

pein

$\mathrm{PCI} / \mathrm{L}$ 
10/26/93 Groundwater Well Results for the 216-5-26 Crib Page 23

Well

Consti tuent Mame

Collect Dote Result Error Filtered oulifier Units

Crol Method Mome

\begin{tabular}{|c|c|}
\hline 299-123-9 & Gross alpha \\
\hline $299-123-9$ & Gross alpha \\
\hline $299-123-9$ & Gross alpha \\
\hline $299-123-9$ & Gross olpha \\
\hline $299-123-9$ & Gross alpha \\
\hline $299-423-9$ & Gross alpha \\
\hline $299-123-9$ & Gross elpha \\
\hline $299-123-9$ & Gross elpha \\
\hline $299-423-9$ & Gross elphe \\
\hline $299-123-9$ & Gross alpha \\
\hline $299-123-9$ & Gross alpha \\
\hline $299-1123-9$ & Gross alpha \\
\hline $299-123-9$ & Gross alpha \\
\hline $299-123-9$ & Grose alpha \\
\hline $299-123-9$ & Gross elpha \\
\hline $299-123-9$ & Groes alpha \\
\hline $299-123-9$ & Gross elpho \\
\hline 299-423-9 & Grose elpha \\
\hline $299-123-9$ & Gross alphe \\
\hline $299-123-9$ & Grose alpha \\
\hline $299-1123-9$ & Gross elphe \\
\hline $299-123-9$ & Gross olphe \\
\hline $299-123-9$ & Grose alphe \\
\hline $299-123-9$ & Grose elpho \\
\hline $299-123-9$ & Gross elpha \\
\hline $299-123-9$ & Groes elphe \\
\hline $299-1023-9$ & Groas elpho \\
\hline $299-123-9$ & Grose alpho \\
\hline $290-123-9$ & Grose alpho \\
\hline
\end{tabular}

$\begin{array}{rrr}1 / 06 / 87 & 33 & 7 \\ 2 / 11 / 87 & 48 & 9 \\ 3 / 13 / 87 & 39 & 7 \\ 4 / 19 / 87 & 24 & 5 \\ 5 / 10 / 87 & 33 & 6 \\ 6 / 09 / 87 & 27 & 5 \\ 7 / 26 / 87 & 27 & 5 \\ 8 / 19 / 87 & 14 & 3 \\ 9 / 16 / 87 & 24 & 5 \\ 10 / 13 / 87 & 19 & 4 \\ 11 / 17 / 87 & 17 & 4 \\ 12 / 11 / 87 & 22 & 4 \\ 1 / 19 / 88 & 26 & 5 \\ 2 / 17 / 88 & 19 & 4 \\ 3 / 18 / 88 & 23 & 5 \\ 4 / 11 / 88 & 19 & 4 \\ 5 / 09 / 88 & 19 & 4 \\ 6 / 15 / 88 & 20 & 4 \\ 7 / 13 / 88 & 20 & 4 \\ 8 / 12 / 88 & 18 & 6 \\ 9 / 08 / 88 & 19 & 4 \\ 10 / 18 / 88 & 21 & 4 \\ 11 / 03 / 88 & 18 & 4 \\ 1 / 05 / 89 & 57 & 10 \\ 1 / 11 / 89 & 26 & 6 \\ 2 / 23 / 89 & 27 & 7 \\ 3 / 10 / 89 & 28 & 6 \\ 10 / 06 / 89 & 49 & 10 \\ 4 / 06 / 90 & 19 & 5\end{array}$

pCi/l

pCi/L

pCi/l

pcill

PCi/L

pCi/L

pCi/L

PCi/L

PCi/L

pCi/L

pci/l

PCi/L

pCi/l

pCi/L

PCi/L

pCi/L

pci/l

pCi/L

pei/l

PCI/L

pcis

PCi/L

pci/l

- pcill

PCi/L

PCi/L

pCi/L

pCi/l

PCI/L 
10/26/93 Groundwater vell Results for the 216-5-26 crib Page 26

well Const ituent Mose



Collect Date Result Error Filtered oulifier Units crol Method Mane

\begin{tabular}{|c|c|c|c|}
\hline $1 / 07 / 86$ & 5 & 2 & pci/l \\
\hline $2 / 07 / 86$ & 7 & 2 & pcis \\
\hline $3 / 10 / 86$ & 6 & 2 & pill \\
\hline $4 / 08 / 86$ & 6 & 2 & pCi/l \\
\hline $5 / 07 / 86$ & 11 & 3 & $\mathrm{pCi} / \mathrm{L}$ \\
\hline $6 / 05 / 86$ & 9 & 3 & $\mathrm{pCi} / \mathrm{L}$ \\
\hline $7 / 08 / 86$ & 16 & 3 & $\mathrm{pCi} / \mathrm{L}$ \\
\hline $9 / 03 / 86$ & 11 & 3 & $\mathrm{pci} / \mathrm{l}$ \\
\hline $11 / 06 / 86$ & 11 & 3 & $\mathrm{PCI} / \mathrm{L}$ \\
\hline $11 / 25 / 86$ & 12 & 3 & $\mathrm{pci} / \mathrm{l}$ \\
\hline $12 / 10 / 86$ & 12 & 3 & pci/l \\
\hline $1 / 06 / 87$ & 22 & 4 & pci/l \\
\hline $2 / 11 / 87$ & 16 & 3 & pci/l \\
\hline $3 / 13 / 87$ & 13 & 3 & pcintl \\
\hline $4 / 19 / 87$ & 12 & 3 & pCi/l \\
\hline $5 / 10 / 87$ & 11 & 3 & $\mathrm{pCi} / \mathrm{L}$ \\
\hline $6 / 09 / 87$ & 15 & 3 & pcill \\
\hline $7 / 24 / 87$ & 13 & 3 & peI/L \\
\hline $8 / 19 / 87$ & 10 & 3 & $\mathrm{pCi} / \mathrm{L}$ \\
\hline $9 / 16 / 87$ & 12 & 3 & $\mathrm{pCl} / \mathrm{L}$ \\
\hline $10 / 13 / 87$ & 9 & 2 & $\mathrm{pCi} / \mathrm{L}$ \\
\hline $11 / 17 / 87$ & 9 & 2 & pci/l \\
\hline $12 / 11 / 87$ & 10 & 3 & $\mathrm{pci} / \mathrm{L}$ \\
\hline $1 / 19 / 88$ & 17 & 3 & $\mathrm{pCi} / \mathrm{L}$ \\
\hline $2 / 17 / 88$ & 13 & 3 & pcirl \\
\hline $3 / 18 / 88$ & 16 & 3 & PCI/L \\
\hline $4 / 11 / 88$ & 10 & 3 & pcish \\
\hline $5 / 09 / 88$ & 15 & 3 & pci/l \\
\hline $6 / 15 / 88$ & 15 & 3 & $\mathrm{pCi} / \mathrm{L}$ \\
\hline $713 / 8$ & 11 & 3 & $\mathrm{CI} / \mathrm{L}$ \\
\hline
\end{tabular}


Well

Constituent Name

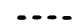

\begin{tabular}{|c|c|}
\hline $299-123-9$ & Gross be \\
\hline $299-123-9$ & Gross b \\
\hline $299-123-9$ & Grose \\
\hline 299-4R3-9 & Gross \\
\hline 299-423-9 & Gross \\
\hline $299-423-9$ & Gross \\
\hline $299-123-9$ & Gross \\
\hline $299-123-9$ & Gross \\
\hline $299-123-9$ & Gross \\
\hline $299-123-9$ & Gross \\
\hline & \\
\hline $299-423-9$ & Witrate \\
\hline 299-123-9 & Mitrate \\
\hline $299-123-9$ & Witrate \\
\hline 299-123-9 & Mitrate \\
\hline $299-123-9$ & Witrate \\
\hline $299-1123-9$ & Mitrate \\
\hline 299-423-9 & Witrate \\
\hline $299-123-9$ & Mitrate \\
\hline $299-123-9$ & Witrate \\
\hline 299-v23-9 & Mitrate \\
\hline $299-123-9$ & Mitrate \\
\hline 299-123-9 & mitrate \\
\hline $299-123-9$ & witrate \\
\hline $299-123-9$ & nitrate \\
\hline $299-123-9$ & witrate \\
\hline $299-1023-9$ & mitrate \\
\hline $299-123-9$ & Witrate \\
\hline $299-1123-9$ & Mitrate \\
\hline
\end{tabular}

Collect Date Result Error Filtered Qualifier Units Collect Date

$8 / 12 / 88$
$9 / 08 / 88$
$10 / 18 / 88$
$11 / 03 / 88$
$1 / 05 / 89$
$1 / 11 / 89$
$2 / 23 / 89$
$3 / 10 / 89$
$10 / 06 / 89$
$4 / 06 / 90$

$7 / 24 / 87$

$8 / 19 / 87$

9/16/87

$10 / 13 / 87$

$11 / 17 / 87$

$12 / 11 / 87$

$1 / 19 / 88$

$2 / 17 / 88$

$3 / 18 / 88$

4/11/88

$5 / 09 / 88$

$6 / 15 / 88$

$7 / 13 / 88$

$8 / 12 / 88$

9/08/88

$10 / 18 / 88$

$11 / 03 / 88$

$1 / 05 / 89$

13
11
13
12
51
20
23
25
31
14

3
3
3
3
7
4
4
4
5
3

409000

285000

262000

142000

82800

77100

90200

99400

105000

100000

101000

102000

99000

95500

92600

78100

24600

54000
Crel

Method Mane

EPA 300.0

EPA 300.0

EPA 300.0

EPA 300.0

EPA 300.0

EPA 300.0

EPA 300.0

EPA 300.0

EPA 300.0

EPA 300.0

EPA 300.0

EPA 300.0

EPA 300.0

EPA 300.0

EPA 300.0 





Mell

Constituent wame

....

$\begin{array}{ll}299-123-9 & \text { stront ium-90 } \\ 299-123-9 & \text { stront ium-90 } \\ 299-123-9 & \text { stront ium-90 } \\ 299-123-9 & \text { Stront ium-90 } \\ 299-123-9 & \text { Stront ium-90 }\end{array}$



Collect Date Result Error Filtered -

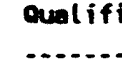

Units

crol

Method Mane

$4 / 11 / 88$
$7 / 13 / 88$
$10 / 18 / 88$
$1 / 11 / 89$
$10 / 06 / 89$

$\begin{array}{rr}-0 & 1 \\ 0 & 1 \\ -0 & 1 \\ 0 & 1 \\ 0 & 1\end{array}$

pci/l

pcin

pcin

pCi/L

pCi/L

\begin{tabular}{|c|c|c|c|c|c|}
\hline $4 / 06 / 90$ & 13400 & 1340 & ppb & & EPA 300.0 \\
\hline $11 / 25 / 91$ & 13000 & 12500 & ppb & 500 & ASTI $0-4327-80$ \\
\hline 4/27/92 & 15000 & 14500 & ppob & 500 & ASTM $0-4327-80$ \\
\hline
\end{tabular}

\begin{tabular}{rrr}
\hline $1 / 07 / 86$ & 151000 & 9020 \\
$2 / 07 / 86$ & 209000 & 12000 \\
$3 / 10 / 86$ & 241000 & 14000 \\
$4 / 08 / 86$ & 422000 & 22600 \\
$5 / 07 / 86$ & 785000 & 40800 \\
$6 / 05 / 86$ & 977000 & 50400 \\
$7 / 08 / 86$ & 1120000 & 57500 \\
$9 / 03 / 86$ & 1320000 & 70900 \\
$11 / 06 / 86$ & 1510000 & 77500 \\
$11 / 25 / 86$ & 1420000 & 73200 \\
$12 / 10 / 86$ & 1320000 & 66600 \\
$1 / 06 / 87$ & 1370000 & 69700 \\
$2 / 11 / 87$ & 1370000 & 69700 \\
$3 / 13 / 87$ & 1470000 & 73600 \\
$4 / 19 / 87$ & 1450000 & 73700 \\
$5 / 10 / 87$ & 1530000 & 77600 \\
$6 / 09 / 87$ & 1550000 & 78700 \\
$7 / 24 / 87$ & 1490000 & 75600
\end{tabular}

pcin

pcin

pCi/L

pCi/l

pCi/L

peis

peill

pcin

pcin

pCirl

peir

peisl

pera

pein

pcin

pci/l

pein

pcin 


$$
\text { well }
$$

Constituent Mame

Collect Date Result

Error

Filtered Oulifier Units

Case

Method Mene

\begin{tabular}{|c|c|}
\hline $299-1123-9$ & Tritiv \\
\hline $299-123-9$ & Tritiun \\
\hline $299-423-9$ & Tritiv \\
\hline $299-123-9$ & Tritiu \\
\hline $299-123-9$ & Tritiu \\
\hline $299-123-9$ & Tritiu \\
\hline $299-123-9$ & Tritiv \\
\hline $299-2123-9$ & Tritic \\
\hline $299-123-9$ & Tritiu \\
\hline $299-1123-9$ & Tritiu \\
\hline $299-1123-9$ & Tritiu \\
\hline $299-1123-9$ & Tritiun \\
\hline $299-123-9$ & Tritiun \\
\hline $299-123-9$ & Tritiun \\
\hline $299-123-9$ & Tritiu \\
\hline $299-1123-9$ & Tritiv \\
\hline 299-123-9 & Trition \\
\hline $299-123-9$ & Iritiun \\
\hline $299-123-9$ & Tritiu \\
\hline $299-123-9$ & Tritiu \\
\hline $299-123-9$ & Tritiu \\
\hline $299-123-9$ & Trition \\
\hline $299-123-9$ & Trition \\
\hline $299-123-9$ & Urenilu \\
\hline $299-123-9$ & Ureniun \\
\hline $299-123-9$ & Urenien \\
\hline $\begin{array}{l}299-123-9 \\
299-123-9\end{array}$ & $\begin{array}{l}\text { Ureniu } \\
\text { Urenium }\end{array}$ \\
\hline
\end{tabular}

\begin{tabular}{rrr}
\hline $8 / 19 / 87$ & 1340000 & 67200 \\
$9 / 16 / 87$ & 1450000 & 72700 \\
$10 / 13 / 87$ & 947000 & 47600 \\
$11 / 17 / 87$ & 776000 & 39000 \\
$12 / 11 / 87$ & 783000 & 57300 \\
$1 / 19 / 88$ & 1280000 & 93700 \\
$2 / 17 / 88$ & 1430000 & 104000 \\
$3 / 18 / 88$ & 1360000 & 99600 \\
$4 / 11 / 80$ & 1320000 & 96600 \\
$5 / 09 / 88$ & 1410000 & 103000 \\
$6 / 15 / 88$ & 1470000 & 107000 \\
$7 / 13 / 88$ & 1430000 & 105000 \\
$8 / 12 / 88$ & 1360000 & 99600 \\
$9 / 08 / 88$ & 1340000 & 97900 \\
$10 / 18 / 88$ & 1440000 & 105000 \\
$11 / 03 / 88$ & 1360000 & 99700 \\
$1 / 05 / 89$ & 1190000 & 87000 \\
$1 / 11 / 89$ & 1140000 & 83000 \\
$2 / 23 / 89$ & 1150000 & 84000 \\
\hline $3 / 10 / 89$ & 1050000 & 76500 \\
\hline $10 / 06 / 89$ & 1520000 & 111000 \\
$4 / 06 / 90$ & 215000 & 15900 \\
$4 / 27 / 92$ & 576000 & 42060 \\
\hline & &
\end{tabular}
$1 / 06 / 87$
2/11/87
$3 / 13 / 87$
$4 / 19 / 87$

$5 / 10 / 87$

..

Units

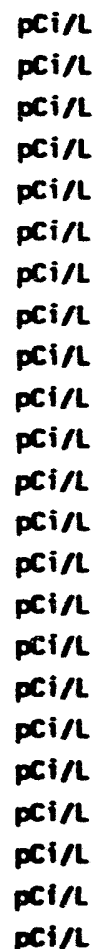

pCi/L

pcin

pCi/l

pCi/l

pCi/L

PCi/L

pirt

$\mathrm{pCi} / \mathrm{L}$

cir

pi/lt

pcirl

pcial

peis

peill

-cir

piilt

pin

pcill

500 ITAS $n-3$

PCi/L

PCi/L

pCi/L

pCi/l

pcin 


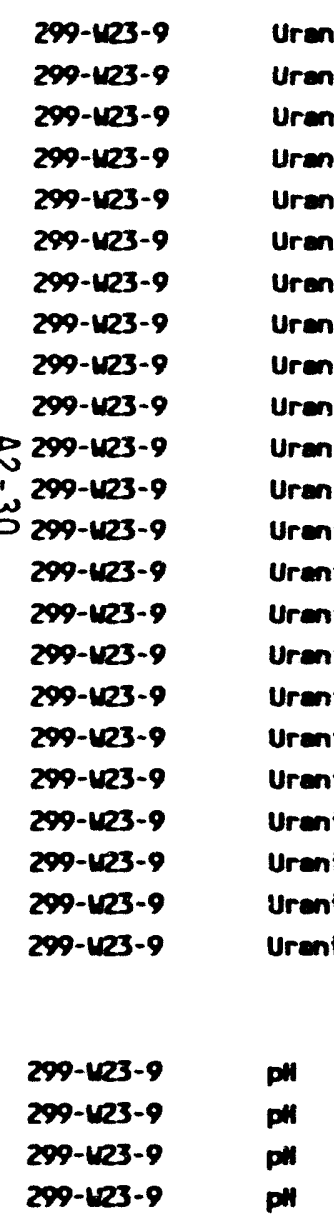

Urenium
Urenium
Urenium
Urenium
Urenium
Urenium
Urenium
Urenium
Urenium
Urenium
Urenium
Urenium
Urenium
Urenium
Urenium
Urenicm
Urenium
Urenium
Urenium
Urenium
Urenium
Urenium
Urenium

$7 / 24 / 87$
$8 / 19 / 87$
$9 / 16 / 87$
$10 / 13 / 87$
$11 / 17 / 87$
$12 / 11 / 87$
$1 / 19 / 88$
$2 / 17 / 88$
$3 / 18 / 88$
$4 / 11 / 88$
$5 / 09 / 88$
$6 / 15 / 88$
$7 / 13 / 88$
$8 / 12 / 88$
$9 / 08 / 88$
$10 / 18 / 88$
$11 / 03 / 88$
$1 / 05 / 89$
$1 / 11 / 89$
$2 / 23 / 89$
$3 / 10 / 89$
$10 / 06 / 89$
$4 / 06 / 90$

$\begin{array}{rr}34 & 10 \\ 27 & 8 \\ 39 & 11 \\ 32 & 10 \\ 29 & 9 \\ 28 & 9 \\ 27 & 8 \\ 29 & 9 \\ 28 & 9 \\ 28 & 9 \\ 28 & 9 \\ 28 & 9 \\ 25 & 8 \\ 26 & 8 \\ 26 & 8 \\ 20 & 7 \\ 25 & 8 \\ 61 & 17 \\ 52 & 15 \\ 73 & 21 \\ 45 & 12 \\ 65 & 17 \\ 18 & 5\end{array}$

pCirl

peinl

pei/l

pei/l

Plin

pci/l

PCi/L

pcin

peis

pein

pCi/L

pCi/L

peirl

pCi/L

pein

peint

pCi/L

pein

pei/l

peint

peirl

pcin

pCi/L

$4 / 06 / 90$

$4 / 06 / 90$

$11 / 25 / 91$

4/27/92

- Probe, pll 
Summary of Provisional Hanford Site Groundwater Background Values" (Johnson, 1993b). (3 sheets)

\begin{tabular}{|c|c|c|c|c|}
\hline $\begin{array}{c}\text { Const ituent } \\
\text { (concentration) }\end{array}$ & PNL Results ${ }^{b}$ & $\begin{array}{l}\text { USGS Results } \\
\text { (sample size) }\end{array}$ & $\begin{array}{l}\text { WHC Unconfined } \\
\text { (sample size) }\end{array}$ & $\begin{array}{l}\text { WHC Provisional } \\
\text { Threshold Values }\end{array}$ \\
\hline $\begin{array}{c}\text { Aluminum } \\
(p p b)\end{array}$ & $<2$ & $\begin{array}{c}110 \pm 139 \\
(12)\end{array}$ & $\begin{array}{l}<200 \\
(50)\end{array}$ & $<200$ \\
\hline $\begin{array}{c}\text { Ammonium } \\
\text { (ppb) }\end{array}$ & $<50$ & WA & $\begin{array}{l}<50 \\
(18)\end{array}$ & $<120$ \\
\hline $\begin{array}{l}\text { Arsenic } \\
\text { (ppb) }\end{array}$ & $3.9 \pm 2.4$ & $\begin{array}{c}6.7 \pm 3.7 \\
(7)\end{array}$ & $\begin{array}{l}<5 \\
(14)\end{array}$ & 10 \\
\hline $\begin{array}{l}\text { Barium } \\
\text { (ppb) }\end{array}$ & $42 \pm 20$ & $\begin{array}{c}53 \pm 14 \\
(11)^{4}\end{array}$ & $\begin{array}{c}41 \pm 20 \\
(53)\end{array}$ & 68.5 \\
\hline $\begin{array}{l}\text { Beryllium } \\
\text { (ppb) }\end{array}$ & $<0.3$ & NA & $\begin{array}{c}<5 \\
(16)\end{array}$ & $<5$ \\
\hline $\begin{array}{l}\text { Bismuth } \\
\text { (ppb) }\end{array}$ & $<0.02$ & NA & $\begin{array}{l}<5 \\
(4)\end{array}$ & $<5$ \\
\hline $\begin{array}{l}\text { Boron } \\
\text { (ppb) }\end{array}$ & $<50$ & $\begin{array}{l}<50 \\
(14)\end{array}$ & $\begin{array}{l}<100 \\
(35)\end{array}$ & $<100$ \\
\hline $\begin{array}{l}\text { Cadmium } \\
\text { (ppb) }\end{array}$ & $<0.2$ & $\begin{array}{l}<10 \\
(1)\end{array}$ & $\begin{array}{l}<10 \\
(16)\end{array}$ & $<10$ \\
\hline $\begin{array}{l}\text { Calcium } \\
\text { (ppb) }\end{array}$ & $40,400 \pm 10,300$ & $\begin{array}{c}40,857 \geq 8,282 \\
(14)^{8}\end{array}$ & $\begin{array}{c}38,542 \pm 11,023 \\
(53)^{11}\end{array}$ & 63,600 \\
\hline $\begin{array}{l}\text { Chloride-low } \\
\text { (ppb) }\end{array}$ & NA & $\begin{array}{c}5,825 \pm 1,355 \\
(8)\end{array}$ & $\begin{array}{c}5.032 \pm 1.774 \\
(53)^{1 .}\end{array}$ & 8,690 \\
\hline $\begin{array}{c}\text { Chloride·high } \\
\text { (ppb) }\end{array}$ & NA & $\begin{array}{c}20,667 \pm 2,503 \\
(6)\end{array}$ & $\begin{array}{c}23,296 \pm 2,463 \\
(14)^{2}\end{array}$ & 28,500 \\
\hline $\begin{array}{c}\text { Chloride-all } \\
\text { (ppb) }\end{array}$ & $10,300 \pm 6,500$ & $\begin{array}{c}12,186 \pm 7,842 \\
(14)\end{array}$ & $\begin{array}{c}8,848 \pm 7,723 \\
(67)\end{array}$ & NC \\
\hline $\begin{array}{c}\text { Chromium } \\
(p p b)\end{array}$ & $4 \pm 2$ & $\begin{array}{l}<50 \\
(11) \\
\end{array}$ & $\begin{array}{l}<30 \\
(8) \\
\end{array}$ & $<30$ \\
\hline $\begin{array}{l}\text { Copper } \\
\text { (ppb) }\end{array}$ & $<1$ & $\begin{array}{l}<10 \\
(10)\end{array}$ & $\begin{array}{l}<30 \\
(50) \\
\end{array}$ & $<30$ \\
\hline $\begin{array}{c}\text { Fluoride } \\
\text { (ppb) }\end{array}$ & $370 \div 100$ & $\begin{array}{c}550 \pm 330 \\
(14)\end{array}$ & $\begin{array}{c}437 \pm 139^{c} \\
(47)\end{array}$ & $\begin{array}{l}1,340 \\
775^{\mathrm{c}}\end{array}$ \\
\hline $\begin{array}{c}\text { Iron-1ow } \\
(p p b)\end{array}$ & NA & $22 \div 16^{c}$ & $\begin{array}{l}<50 \\
(34) \\
\end{array}$ & 86 \\
\hline $\begin{array}{l}\text { Iron-mid } \\
\text { (ppb) }\end{array}$ & NA & NA & $\begin{array}{c}115 \pm 52 \\
(7)^{2}\end{array}$ & 291 \\
\hline $\begin{array}{c}\text { Iron-high } \\
(\mathrm{ppb})\end{array}$ & NA & NA & $\begin{array}{c}494 \pm 118 \\
(12)^{18}\end{array}$ & 818 \\
\hline $\begin{array}{c}\text { Iron-all } \\
\text { (ppb) }\end{array}$ & NA & NA & $\begin{array}{c}149 \pm 199 \\
(53)\end{array}$ & NC \\
\hline $\begin{array}{l}\text { Lead } \\
\text { (ppb) }\end{array}$ & $<0.5$ & $\begin{array}{l}<30^{c} \\
(6) \\
\end{array}$ & $\begin{array}{r}<5 \\
(15) \\
\end{array}$ & $<5$ \\
\hline $\begin{array}{l}\text { Magnesium } \\
(p p b)\end{array}$ & $11,800 \pm 3,400$ & $\begin{array}{c}10,814 \pm 1,813 \\
(14)\end{array}$ & $\begin{array}{c}11,190 \pm 2,578 \\
(14)^{2}\end{array}$ & 16,840 \\
\hline $\begin{array}{l}\text { Manganese- low } \\
\text { (ppb) }\end{array}$ & NA & $\begin{array}{c}26 \pm 27 \\
(8)\end{array}$ & $\begin{array}{r}<20 \\
(33) \\
\end{array}$ & 24.5 \\
\hline $\begin{array}{c}\text { Manganese } \cdot \text { high } \\
(p p b)\end{array}$ & NA & $\begin{array}{c}150 \pm 87 \\
(3)\end{array}$ & $\begin{array}{c}118 \pm 17 \\
(20)\end{array}$ & 163.5 \\
\hline
\end{tabular}


Summary of Provisiona? Hanford Site Groundwater Background Values (Johnson, 1993b). (3 sheets)

\begin{tabular}{|c|c|c|c|c|}
\hline $\begin{array}{c}\text { Constituent } \\
\text { (concentration) }\end{array}$ & PNL Results & $\begin{array}{l}\text { USGS Results } \\
\text { (sample size) }\end{array}$ & $\begin{array}{l}\text { WHC Unconfined } \\
\text { (sample size) }\end{array}$ & $\begin{array}{l}\text { WHC Provisional } \\
\text { Threshold Values }\end{array}$ \\
\hline $\begin{array}{l}\text { Manganese-all } \\
\text { (ppb) }\end{array}$ & $\cdots$ & $\begin{array}{l}60 \pm 73 \\
(11)^{2}\end{array}$ & $\begin{array}{c}50 \pm 55 \\
(53)\end{array}$ & NC \\
\hline $\begin{array}{l}\text { Mercury } \\
\text { (ppb) }\end{array}$ & $\cdots$ & NA & $\begin{array}{l}<0.1 \\
(14)\end{array}$ & $<0.1$ \\
\hline $\begin{array}{l}\text { Nickel } \\
\text { (ppb) }\end{array}$ & $<4$ & $\begin{array}{l}<50 \\
(14)\end{array}$ & $\begin{array}{l}<30 \\
(23)\end{array}$ & $<30$ \\
\hline $\begin{array}{l}\text { Nitrate } \\
\text { (ppo) }\end{array}$ & NA & $\begin{array}{c}3,224 \pm 3,380 \\
(13)^{-3}\end{array}$ & $\begin{array}{c}5,170 \pm 3,576 \\
(78)\end{array}$ & 12,400 \\
\hline $\begin{array}{l}\text { Phosphare } \\
\text { (Ppb) }\end{array}$ & $<1000$ & $\begin{array}{c}140 \pm 62 \\
(3)\end{array}$ & $<1,000$ & $<1,000$ \\
\hline $\begin{array}{l}\text { Potassium } \\
\text { (ppb) }\end{array}$ & $4,950 \div 1,240$ & $\begin{array}{c}5,900 \pm 1,253 \\
(14)^{-1}\end{array}$ & $\begin{array}{c}4.993 \pm 1,453 \\
(53)^{1.45}\end{array}$ & 7.975 \\
\hline $\begin{array}{l}\text { Selenium } \\
\text { (ppb) }\end{array}$ & $<2$ & NA & $\begin{array}{l}<5 \\
(14)\end{array}$ & $<5$ \\
\hline $\begin{array}{l}\text { Silver } \\
\text { (ppb) }\end{array}$ & $<10$ & NA & $<10$ & $<10$ \\
\hline $\begin{array}{l}\text { silicon } \\
\text { (ppb) }\end{array}$ & NA & $\begin{array}{c}16,786 \pm 3,683 \\
(14)\end{array}$ & $\begin{array}{c}18,152 \pm 4,974 \\
(35)^{4}\end{array}$ & 26,500 \\
\hline $\begin{array}{l}\text { Sodium } \\
\text { (ppb) }\end{array}$ & $18,260 \pm 10.150$ & $\begin{array}{c}20,286 \pm 7,907 \\
(14)\end{array}$ & $\begin{array}{c}15,774 \leq 6,784 \\
(53)\end{array}$ & 33,500 \\
\hline $\begin{array}{l}\text { Strontium } \\
\text { (ppb) }\end{array}$ & $236 \pm 102$ & $\begin{array}{c}159 \pm 78 \\
(14)\end{array}$ & $\begin{array}{c}164 \pm 47 \\
(43)\end{array}$ & 264.1 \\
\hline $\begin{array}{l}\text { Sul fate } \\
\text { (ppb) }\end{array}$ & $34,300 \div 16,900$ & $\begin{array}{c}41,286 \pm 27,830 \\
(14)\end{array}$ & $\begin{array}{c}30,605 \pm 22,611 \\
(67)\end{array}$ & 90,500 \\
\hline $\begin{array}{l}\text { Uranium } \\
(p C i / L)\end{array}$ & $1.7 \neq 0.8$ & NA & $\begin{array}{c}1.7 \pm 1.2 \\
(10)\end{array}$ & 3.43 \\
\hline $\begin{array}{l}\text { Vanadium } \\
(p p b)\end{array}$ & $17 \pm 9$ & NA & $\begin{array}{r}9 \pm 4 \\
(18)\end{array}$ & 15 \\
\hline $\begin{array}{l}\text { 2inc-low } \\
(\mathrm{ppb})\end{array}$ & NA & $\begin{array}{c}14 \pm 20 \\
(11)\end{array}$ & $\begin{array}{l}<50 \\
(36)\end{array}$ & $<50$ \\
\hline $\begin{array}{l}\text { zinc-high } \\
\text { (ppb) }\end{array}$ & NA & $\begin{array}{c}373 \pm 284 \\
(3)\end{array}$ & $\begin{array}{c}247 \pm 165 \\
(17)^{165}\end{array}$ & 673 \\
\hline $\begin{array}{c}2 \text { inc-all } \\
(p p b)\end{array}$ & $6 \pm 2$ & $\begin{array}{c}91 \pm 190 \\
(14)\end{array}$ & $\begin{array}{c}95 \pm 140 \\
(53)\end{array}$ & NC \\
\hline $\begin{array}{l}\text { field olkal inity } \\
\text { (ppb) }\end{array}$ & $\overline{N A}$ & $\begin{array}{c}134,100 \pm 20,469 \\
(10)\end{array}$ & $\begin{array}{c}137,758 \pm 33,656 \\
\text { (31) }\end{array}$ & 215,000 \\
\hline $\begin{array}{c}\text { Lab alkal inity } \\
\text { (ppb) }\end{array}$ & $123,000 \pm 21,000$ & $\begin{array}{c}130,000 \div 8,165 \\
(4)\end{array}$ & $\begin{array}{c}133,717 \pm 29,399 \\
(52)\end{array}$ & 210,000 \\
\hline field $\mathrm{pH}$ & NA & NA & $\begin{array}{c}7.57 \pm 0.29 \\
(57)\end{array}$ & $(6.90,8.24)$ \\
\hline Lab pH & $7.64 \pm 0.16$ & NA & $\begin{array}{c}7.75 \pm 0.21 \\
(52)\end{array}$ & {$[7.25,8.25]$} \\
\hline $\begin{array}{l}\text { Total organic } \\
\text { carbon (ppb) }\end{array}$ & $586 \pm 347$ & NA & $\begin{array}{c}519 \pm 367^{c} \\
(62)\end{array}$ & $\begin{array}{l}2,610 \\
1,610^{c}\end{array}$ \\
\hline
\end{tabular}




\section{Summary of Provisional Hanford Site Groundwater Background Values} (Johnson, 1993b). (3 sheets)

\begin{tabular}{|c|c|c|c|c|}
\hline $\begin{array}{c}\text { Constituent } \\
\text { (concentration) }\end{array}$ & PNL Results ${ }^{b}$ & $\begin{array}{l}\text { USGS Results } \\
\text { (sample size) }\end{array}$ & $\begin{array}{l}\text { WHC Unconfined } \\
\text { (sample size) }\end{array}$ & $\begin{array}{l}\text { WHC Provisional } \\
\text { Threshold Values }\end{array}$ \\
\hline 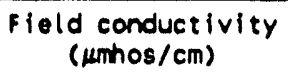 & NA & NA & $\begin{array}{l}344 \pm 83 \\
(22)\end{array}$ & 539 \\
\hline $\begin{array}{l}\text { Lab conductivity } \\
\text { (umhos/cm) }\end{array}$ & $380 \div 82$ & NA & $\begin{array}{c}332 \pm 93 \\
(36)\end{array}$ & 530 \\
\hline $\begin{array}{l}\text { Total organic } \\
\text { halogen, lower } \\
\text { detection limit } \\
\text { (ppo) }\end{array}$ & NA & NA & $\begin{array}{l}<20^{c} \\
(14)\end{array}$ & $\begin{array}{l}60.8 \\
37.6^{c}\end{array}$ \\
\hline $\begin{array}{l}\text { Total carbon } \\
\text { (ppb) }\end{array}$ & NA & NA & $\begin{array}{c}31,772 \pm 7,022 \\
(48)\end{array}$ & 50,100 \\
\hline $\begin{array}{l}\text { Gross alpha } \\
(\mathrm{pC} i / \mathrm{L})\end{array}$ & $2.5 \pm 1.4$ & NA & $\begin{array}{c}2.5 \pm 1.5^{c} \\
(36)^{c}\end{array}$ & $5.79^{c} \mathrm{c}$ \\
\hline $\begin{array}{l}\text { Gross beta } \\
(p C i / L)\end{array}$ & $19 \pm 12$ & NA & $\begin{array}{c}7.1 \pm 2.6^{c} \\
(44)\end{array}$ & $\begin{array}{c}35.5 \\
12.62^{c}\end{array}$ \\
\hline $\begin{array}{l}\text { Radium } \\
(\mathrm{PCi} / \mathrm{L})\end{array}$ & $<0.2$ & NA & $\begin{array}{l}\text { ND } \\
(10)\end{array}$ & 0.23 \\
\hline
\end{tabular}

Note: Johnson, V. G., 1993, Westinghouse Hanford Company Operational Groundwater Status Report, WHC-EP.0595, Westinghouse Hanford Company, Richland, Washington.

Source: From Tables 5.9 and 5.11 (DOE-RL, 1992, Hanford Site Groundwater Background,

DOE/RL-92-23, U.S. Department of Energy, Richland Operations Office, Richland, Washington).

b Results shown are mean \pm one standard deviation.

C Potential outlier observation(s) were removed.

NA = not available.

NC = not calculated.

ND = not detected.

PNL = Pacific Northwest Laboratory.

Ppb $=$ parts per billion.

USCS = United States Geological Survey.

WHC = West inghouse Hanford Company. 
WHC-EP-0690

This page intentionally left blank. 
WHC-EP-0690

APPENDIX B

CHEMISTRY PLOTS

$B-i$ 
ֻ.



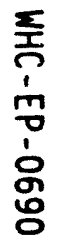


Chemistry data correlation plots of the available effluent and groundwater monitoring data were created and are shown in this appendix. Some of these plots were also used in the text of the document. The plots are of two basic types:

1. Plots showing 216-S-26 (S-26) effluent data, wel1 299-W27-1 groundwater data, and the Hanford Site background average concentration data (Johnson 1993b)

2. Plots showing groundwater data for wells near upgradient past-practice disposal sites and contaminant sources in the vicinity of the S-26 Crib and for comparison, Hanford Site background average concentration data.

The plots were created to illustrate differences between the different sites sampled. The Hanford Site background average concentration was plotted to show how the concentration of a given constituent in effluent and/or groundwater compared to the background unconfined aquifer concentration. Concentrations which are lower than the average value are most likely the result of disposal of Hanford Site "system water" (i.e. treated Columbia River water), with little or no contamination. Concentrations which are higher than the average value are most likely the result of disposal of wastewater from Hanford Site processes and operations (i.e. process facility effluent), which is often elevated in concentration and contaminated. The parameters which are elevated can be used to determine the source of the "contamination" if enough is known about the composition of the wastewater that was originally discharged to a given facility.

For the first set of plots, the effluent consistently plotted below the Hanford Site background average for the unconfined aquifer. Groundwater data from well 299-W27-1 consistently had higher concentrations than the Hanford Site background values. Effluent discharged to the S-26 Crib and groundwater beneath the crib differ greatly in concentration; the elevated concentrations seen in the groundwater are not a result of discharge to the crib.

The second set of plots which show upgradient groundwater concentrations also exhibit trends. Some wells are elevated in concentration and are also higher than the Hanford Site background average concentration for the unconfined aquifer. Although these wells have elevated concentrations, the values have decreased somewhat from the highest values recorded in the late $1980^{\prime} \mathrm{s}$. Well 299-22-20 consistently exhibited concentrations which followed this trend. It is the one well which is most likely downgradient of several of the potential sources of contamination from past-practice operations. Two other wells, 299-W23-9 which is downgradient of the 216-S-25 (S-25) Crib and 299-W22-21 which is downgradient of the 216-S-13 (S-13) Crib, also exhibited this trend to a lesser degree. Wells 299-W22-12 which is downgradient of the 216-S-7 (S-7) Crib, 299-W22-7 which is downgradient of the 216-S-9 (S-9) Crib, and 299-W22-10 which is downgradient of the 216-S-1 (S-1) and 216-S-2 (S-2) Cribs, showed concentrations which were slightly elevated or just below the Hanford Site background average concentrations. All the wells showed elevated concentrations of gross alpha and beta, but to varying degrees.

It is difficult to rule out any of the upgradient sources based on these data. The elevated concentrations found at well 299-W23-9 are definitely related to the S-25 Crib disposal operations. The source of the elevated 
concentrations at well 299-W-22-20 is more difficult to determine. Given its downgradient location from several disposal facilities and the length of time since some of these facilities last received discharges of wastewater, it is not surprising that the wells near the facilities do not show elevated concentrations and 299-W-22-20 which is further downgradient does show elevated concentrations. The contaminated groundwater has moved downgradient from the wells in the immediate vicinity of S-1, S-2, S-7, and S-13 Cribs, and is now affecting well 299-W22-20 and 299-W27-1 (at the S-26 Crib site).

Therefore, all of the cribs mentioned above are the likely sources of the elevated concentrations and contaminants seen in wells upgradient of and at the S-26 Crib. Disposal of effluents to the S-26 Crib is mainly diluting the groundwater beneath the site with less concentrated "river water".

The plots are shown together in pairs (one of each type) for each parameter plotted, with the exception of potassium and magnesium, which only have a plot of type 1 . The plots are grouped as follows:

\footnotetext{
- Groundwater quality indicators - pH, specific conductance (conductivity)

- Cations - Magnesium, potassium, sodium, calcium, and barium

- Metals - Strontium, selenium, vanadium, and zinc

- Anions - Chloride, nitrate, and sulfate

- Radionuclides - Total uranium, strontium-90, tritium, gross alpha and gross beta.
} 
WHC-EP- 0690

This page intentionally left blank. 
WHC-EP-0690

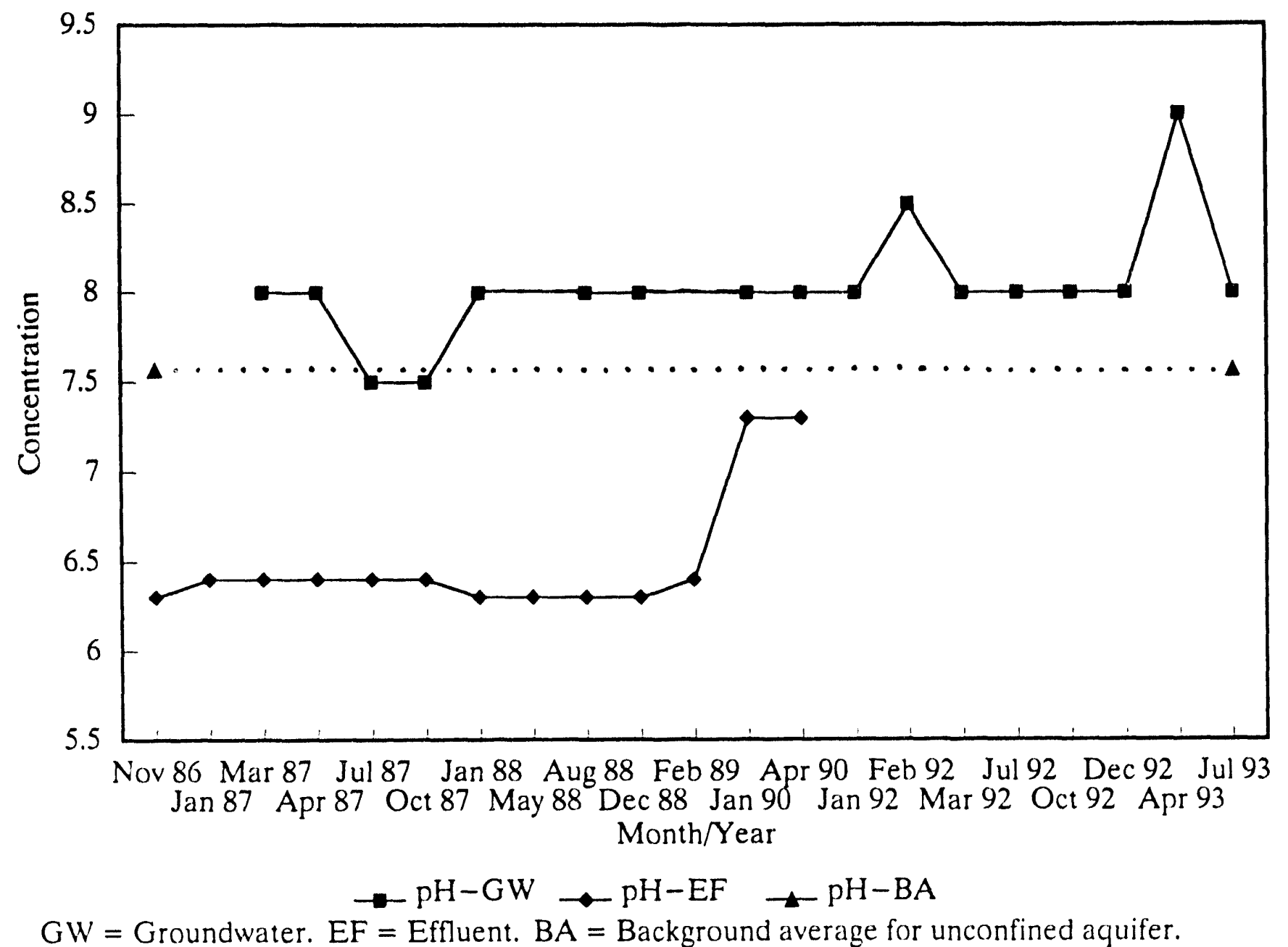


WHC-EP-0690

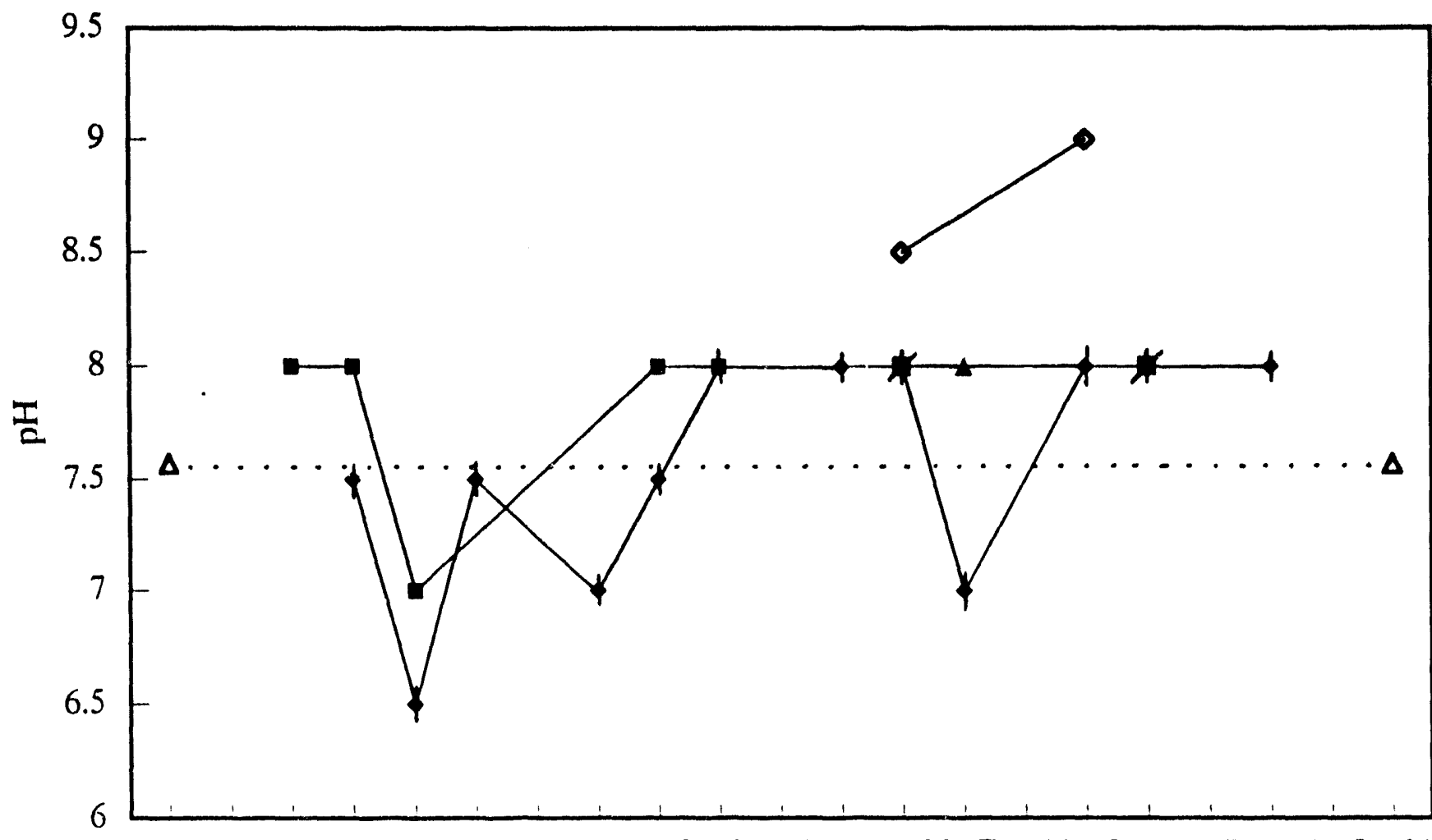

Nov 86 Mar 87 Jul 87 Jan 88 Aug 88 Feb 89 Apr 90 Feb 92 Jul 92 Dec 92 Jul 93 Jan 87 Apr 87 Oct 87 May 88 Dec 88 Jan 90 Jan 92 Mar 92 Oct 92 Apr 93 Month/Year

$\rightarrow$ Well W22-12

- Well W22-20
$\uparrow$ Well W23-9

$\rightarrow$ Well W22-21

Æ Well W22-10

$\triangle$ - Background Average

Note: Graph illustrates groundwater data from wells upgradient of the 216-S-26 Crib location.

Background Average = Hanford Site background average concentration for the unconfined aquifer and it is shown as a dotted line on the graph. 


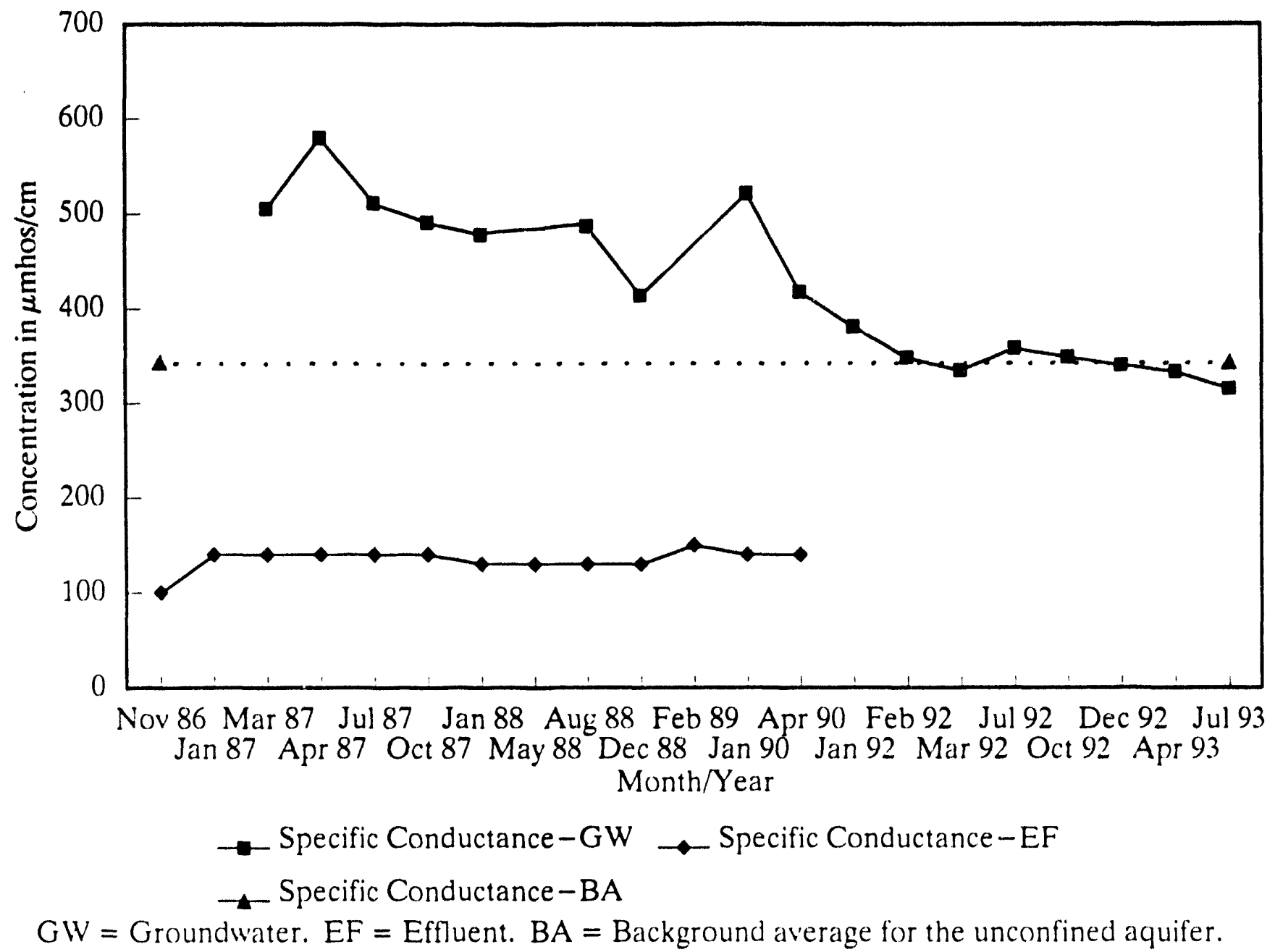




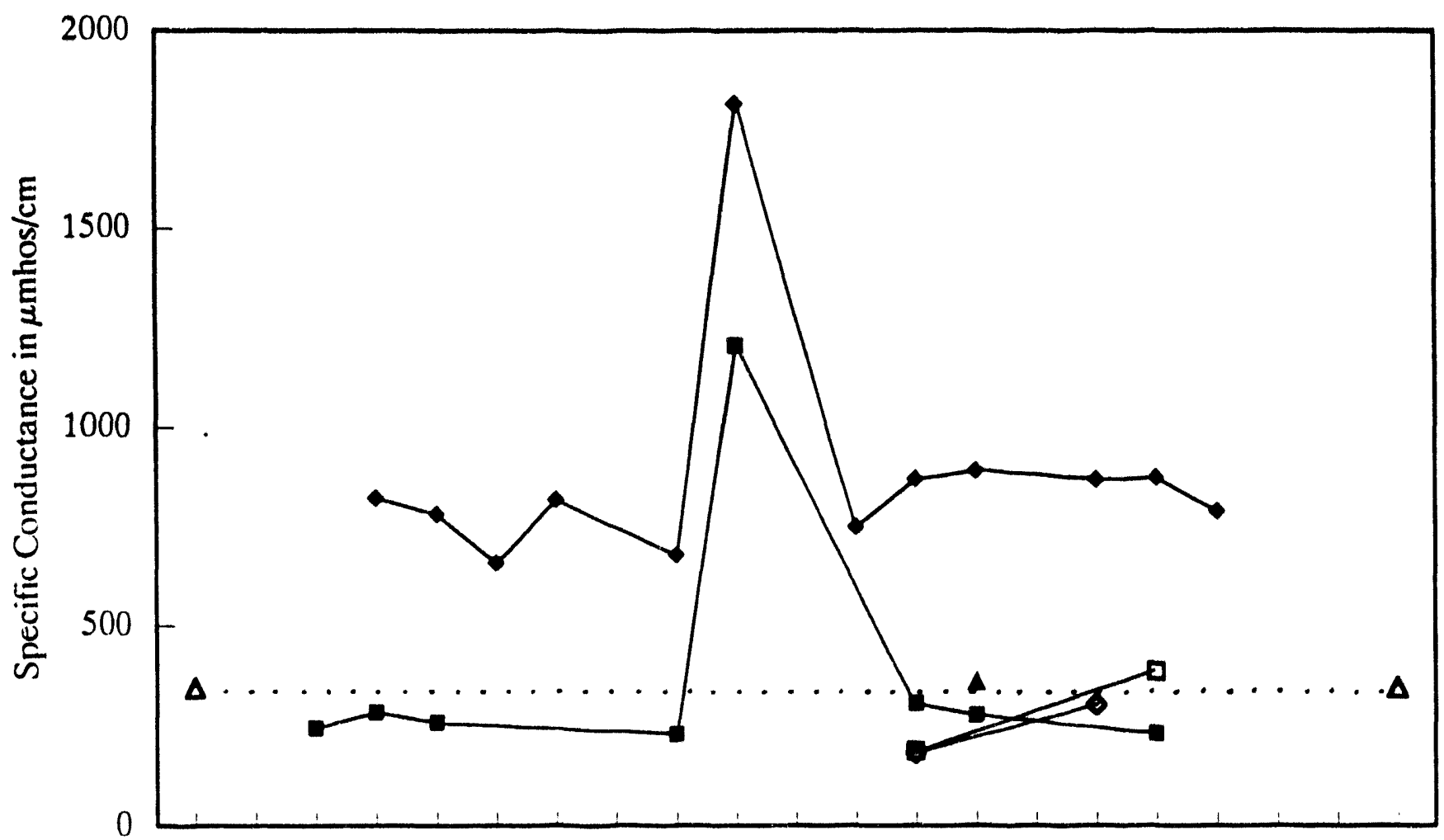

Nov 86 Mar 87 Jul 87 Jan 88 Aug 88 Feb 89 Apr 90 Feb 92 Jul 92 Dec 92 Jul 93 Jan 87 Apr 87 Oct 87 May 88 Dec 88 Jan 90 Jan 92 Mar 92 Oct 92 Apr 93 Month/Year

$\rightarrow-$ Well W22-12

$\neg$ Well W22-20

$\rightarrow$ Well W22-21

$\rightarrow$ Well W22-10

$\rightarrow$ Well W23-9

$\triangle$ Background Average

Note: Graph 1llustrates groundwater data from wells upgradient of the 216-5-26 Crib location.

Background Average = Hanford Site background average concentration for the unconfined aquifer and it is shown as a dotted line on the graph. 


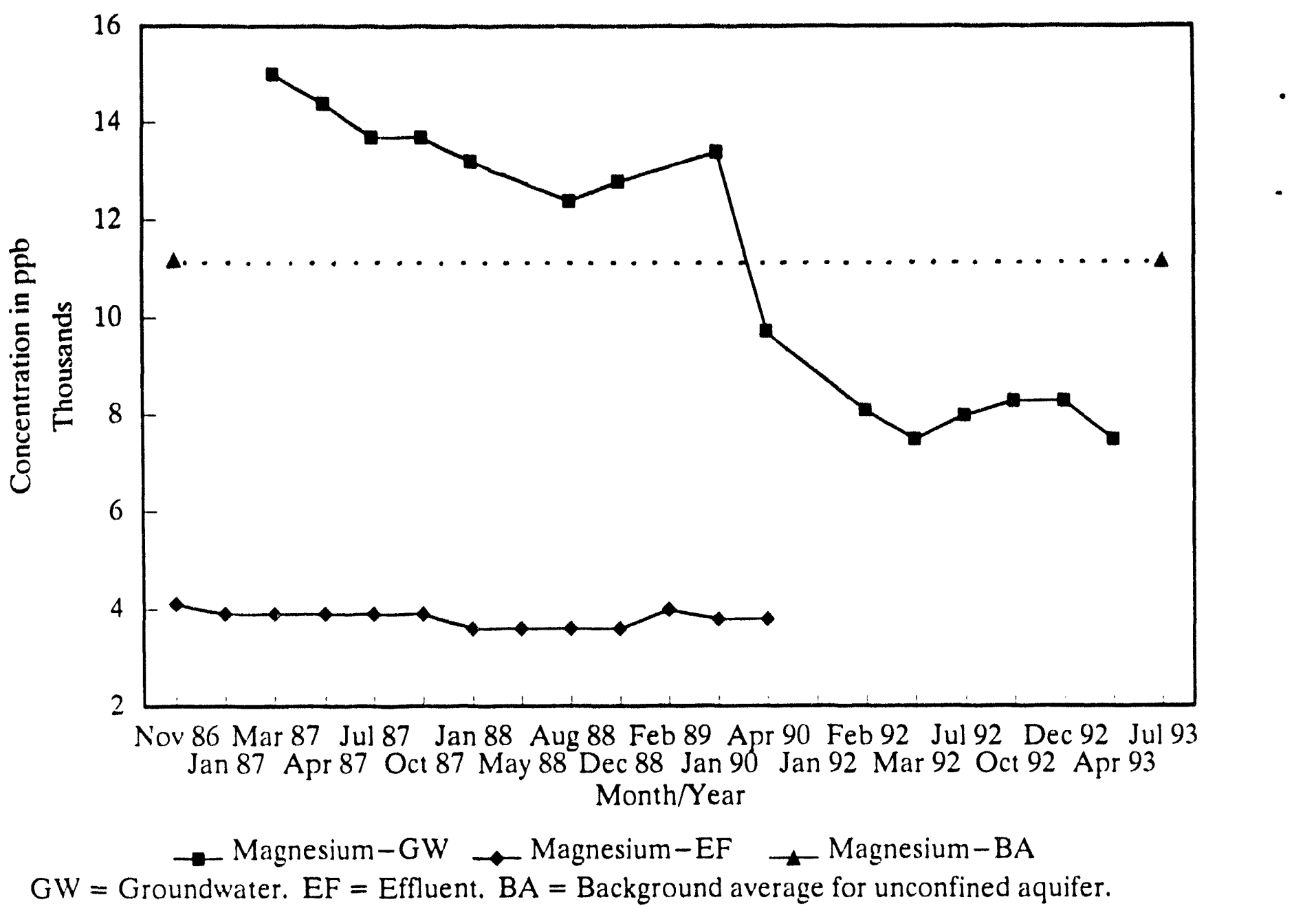





$\forall \mathrm{g}-$ un!sselo $\rightarrow \quad \exists \exists-$ un!sselo $\rightarrow \mathrm{MO}_{\mathrm{d}} \rightarrow$ un!sselo $\rightarrow$ IEว $\mathrm{N} / \mathrm{Y}+\mathrm{HOW}$

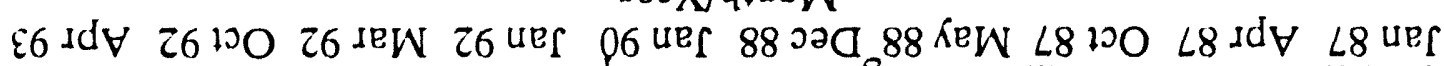



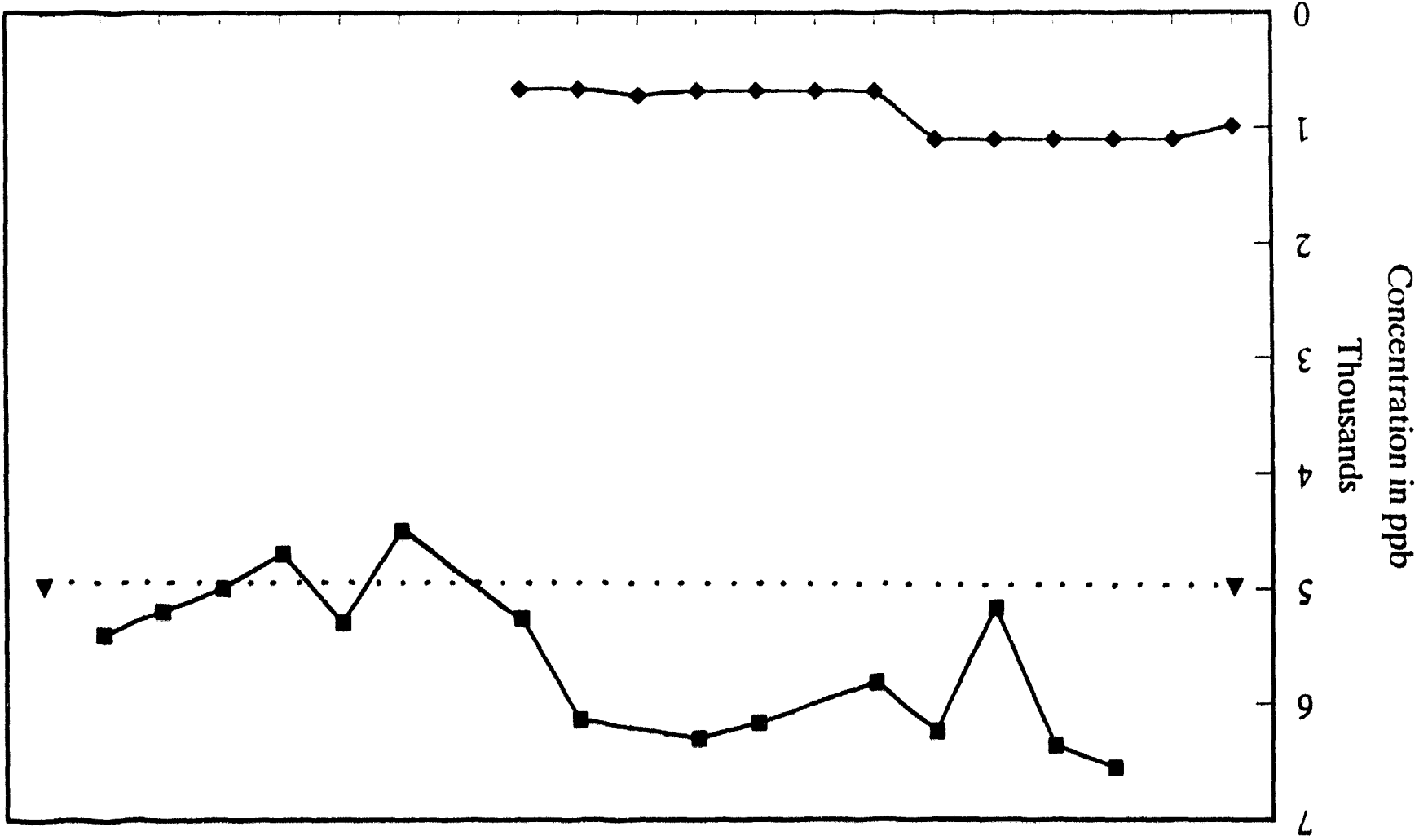


WHC-EP-0690

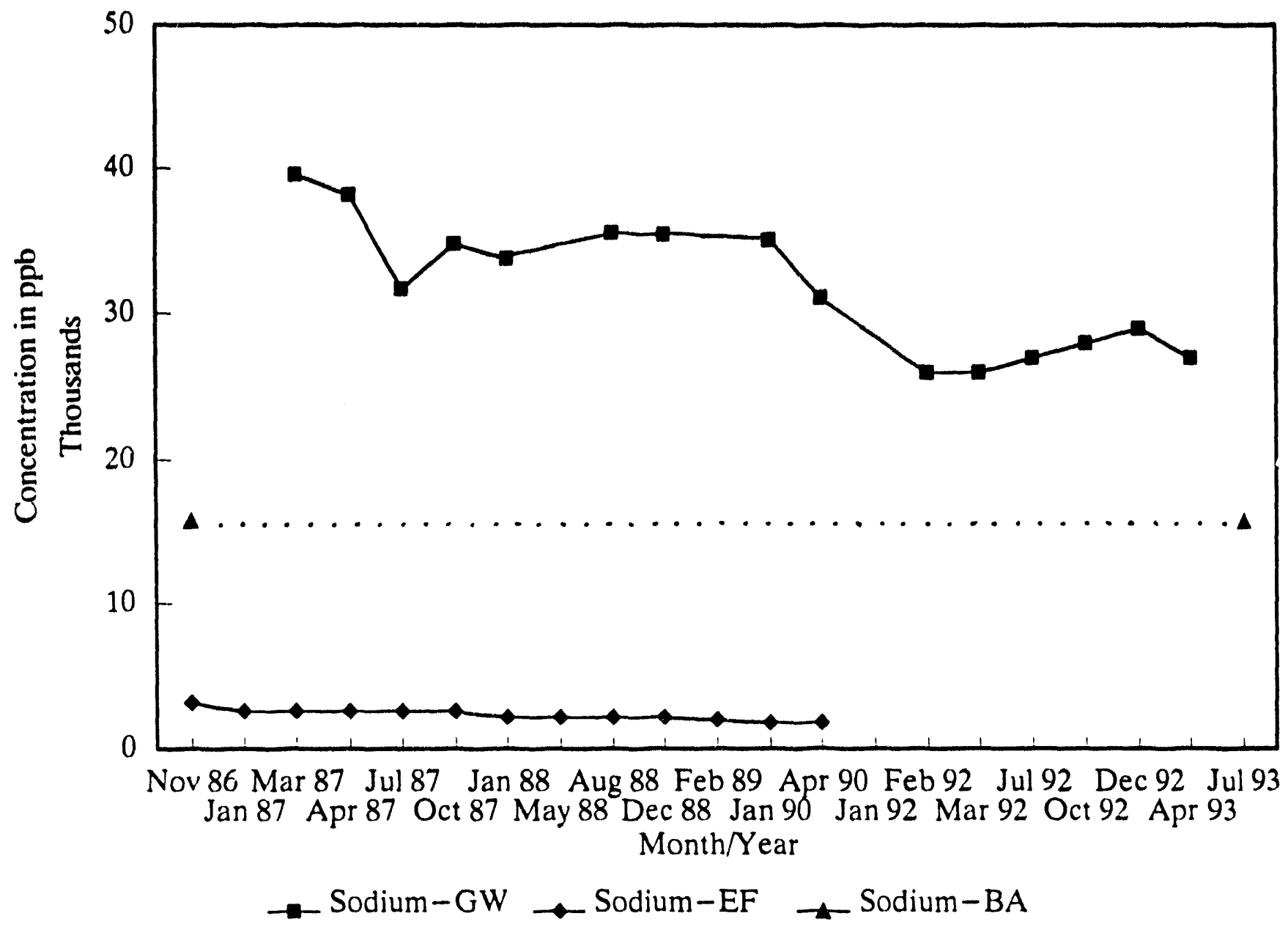

$\mathrm{GW}=$ Groundwater. $\mathrm{EF}=$ Effluent. $\mathrm{BA}=$ Background average for unconfined aquifer. 


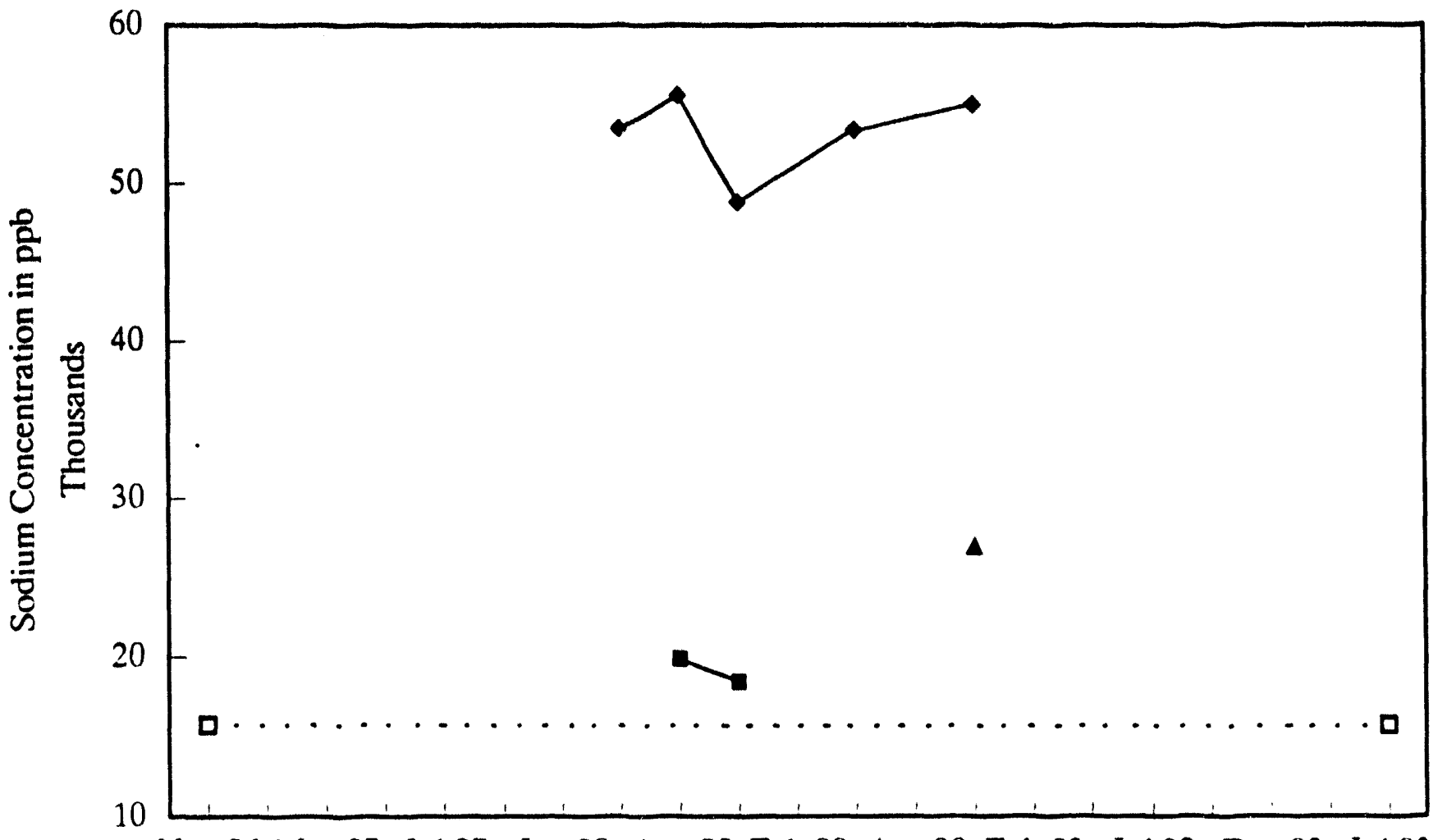

Nov 86 Mar 87 Jul 87 Jan 88 Aug 88 Feb 89 Aur 90 Feb 92 Jul 92 Dec 92 Jul 93 Jan 87 Apr 87 Oct 87 May $88^{\circ}$ Dec 88 Jan 90 Jan 92 Mar 92 Oct 92 Apr 93 Month/Year

$$
\begin{aligned}
& \rightarrow \text { Well W22-12 } \rightarrow \text { Well W22-20 } \\
& \rightarrow \text { Well W22-21 } \rightarrow \text { Background Average }
\end{aligned}
$$

Note: Graph illustrates groundwater data from wells upgradient of the 216-S-26 Crib location.

Background Average = Hanford Site background average concentration for the unconfined aquifer and it is shown as a dotted line on the graph. 
WHC-EP-0690

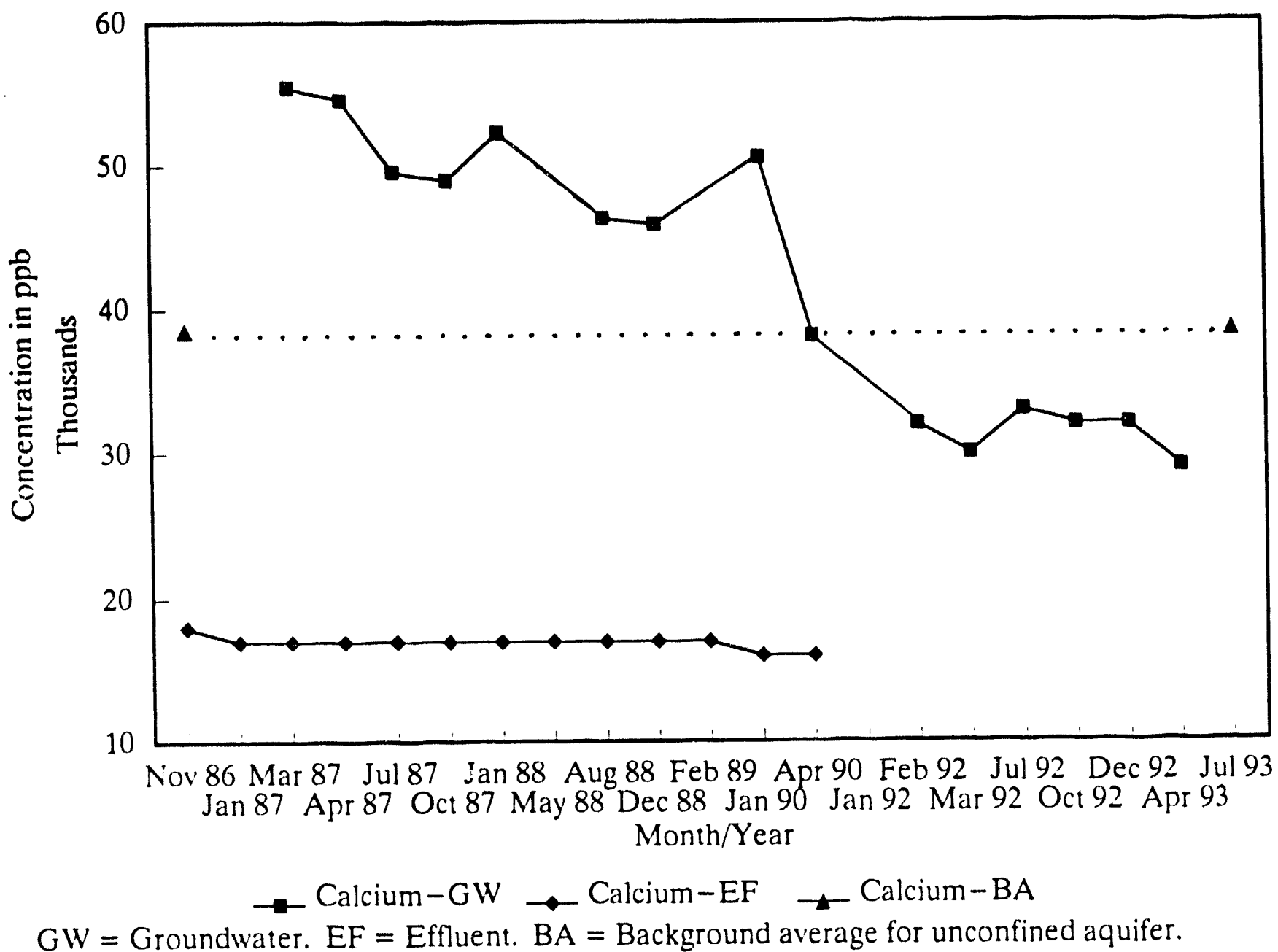






Nov 86 Mar 87 Jul 87 Jan 88 Aug 88 Feb 89 Apr 90 Feb 92 Jul 92 Dec 92 Jul 93 Jan 87 Apr 87 Oct 87 May 88 Dec 88 Jan 90 Jan 92 Mar 92 Oct 92 Apr 93 Month/Year

$\rightarrow-$ Well W22-12

$\neg$ Well W22-20

$\rightarrow$ Well W22-21

$\rightarrow$ Background Average ${ }^{\prime}$

Note: Graph illustrates groundwater data from wells upgradient of the 216-S-26 Crib location.

Background Average = Hanford Site background average concentration for the unconfined aquifer and it is shown as a dotted line on the graph. 


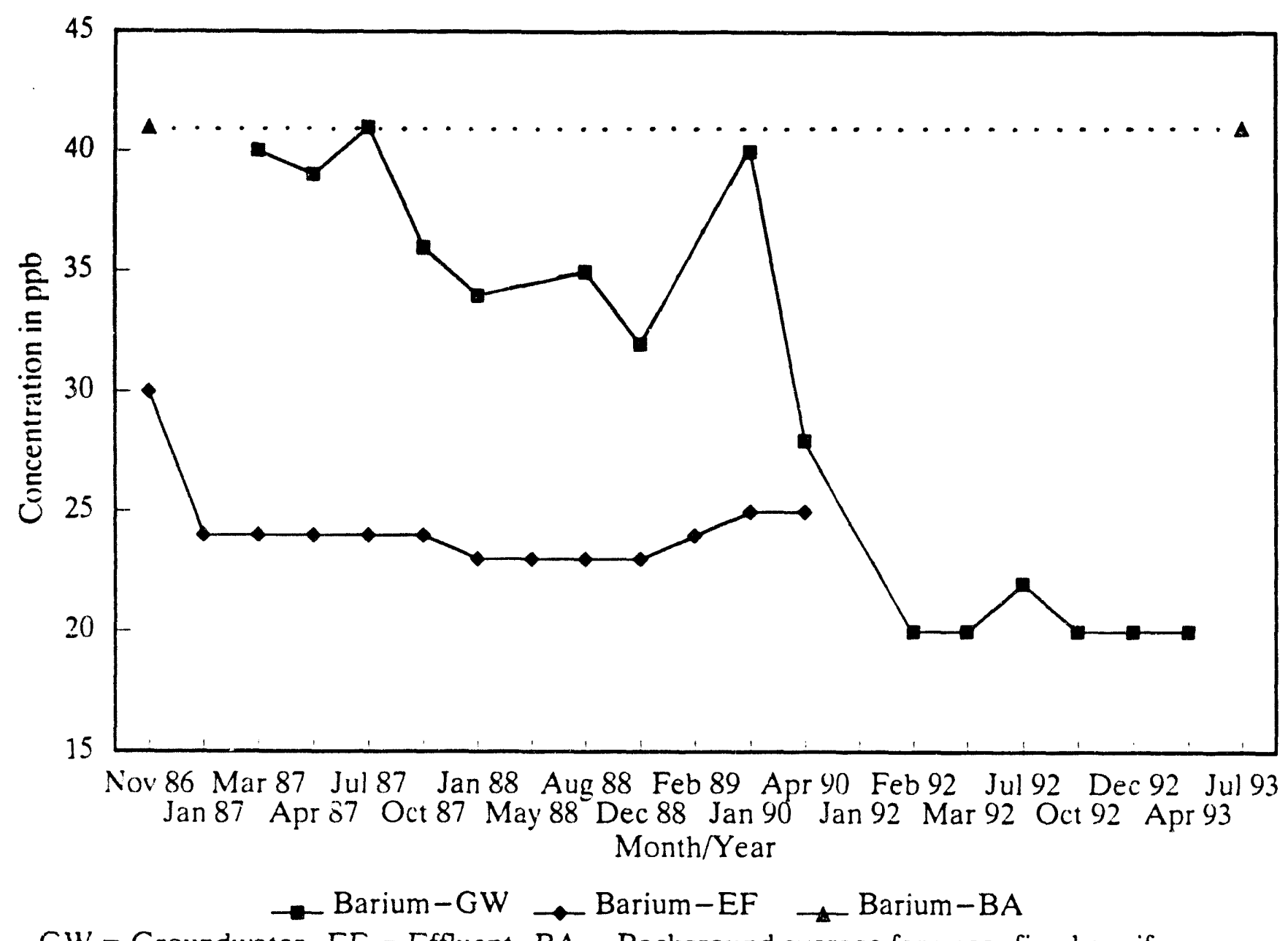

$G W^{\prime}=$ Groundwater. $E F=$ Effluent. $B A=B$ ackground average for unconfined aquifer. 


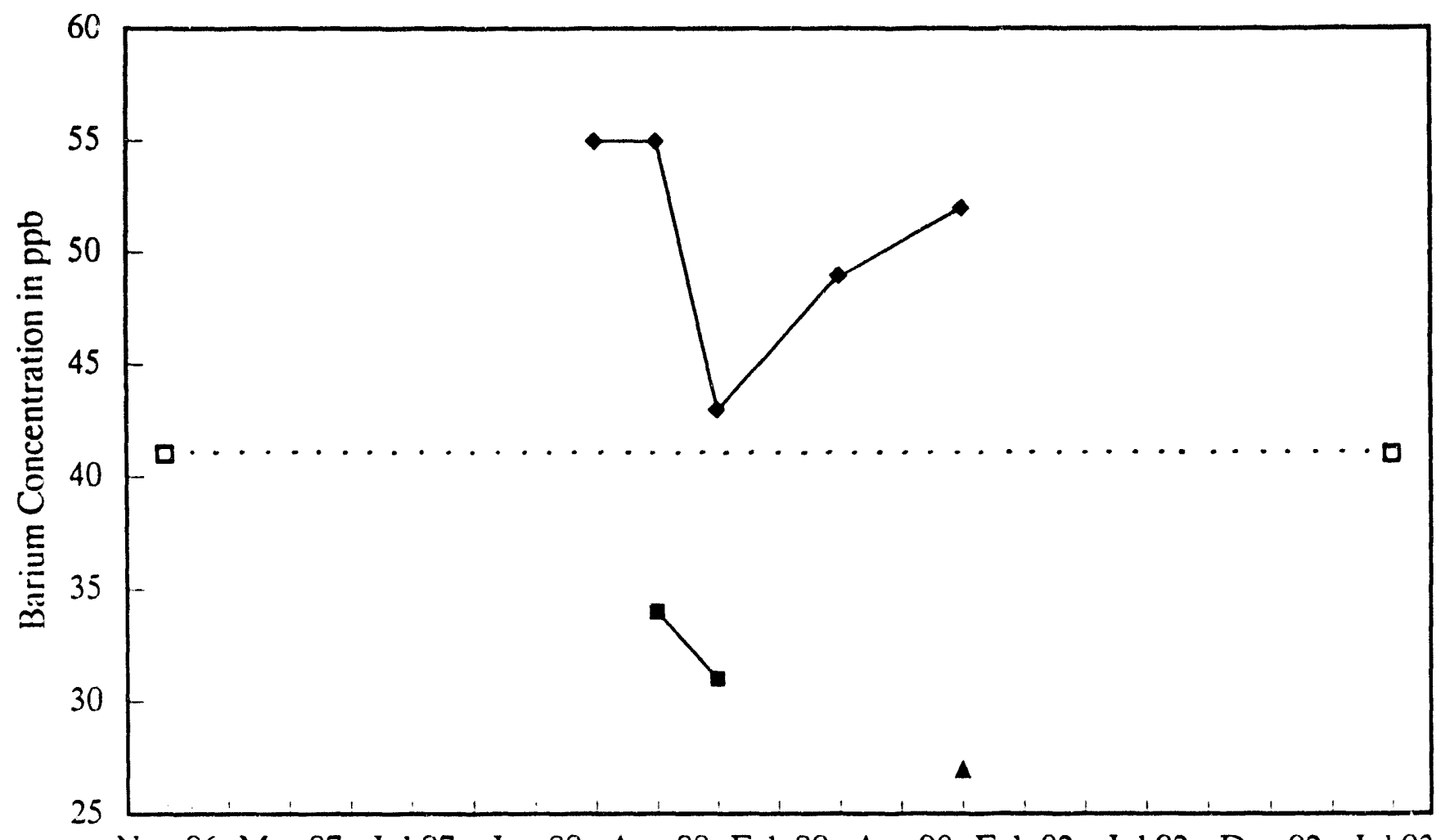

Nov 86 Mar 87 Jul 87 Jan 88 Aug 88 Feb 89 Apr 90 Feb 92 Jul 92 Dec 92 Jul 93 Jan 87 Apr 87 Oct 87 May 88 Dec 88 Jan 90 Jan 92 Mar 92 Oct 92 Apr 93 Month/Year

$$
\begin{aligned}
& \rightarrow \text { Well W22-12 } \rightarrow \text { Well W22-20 } \\
& \rightarrow \text { Well W22-21 - }- \text { Background Average }
\end{aligned}
$$

Note: Graph illustrates groundwater data from wells upgradient of the 216-S-26 Crib location.

Background Average = Hanford Site background average concentration for the unconfined aquifer and it is shown as a dotted line on the graph. 




$\mathrm{GW}=$ Groundwater. $\mathrm{EF}=$ Effluent. $\mathrm{BA}=$ Background average for unconfined aquifer. 


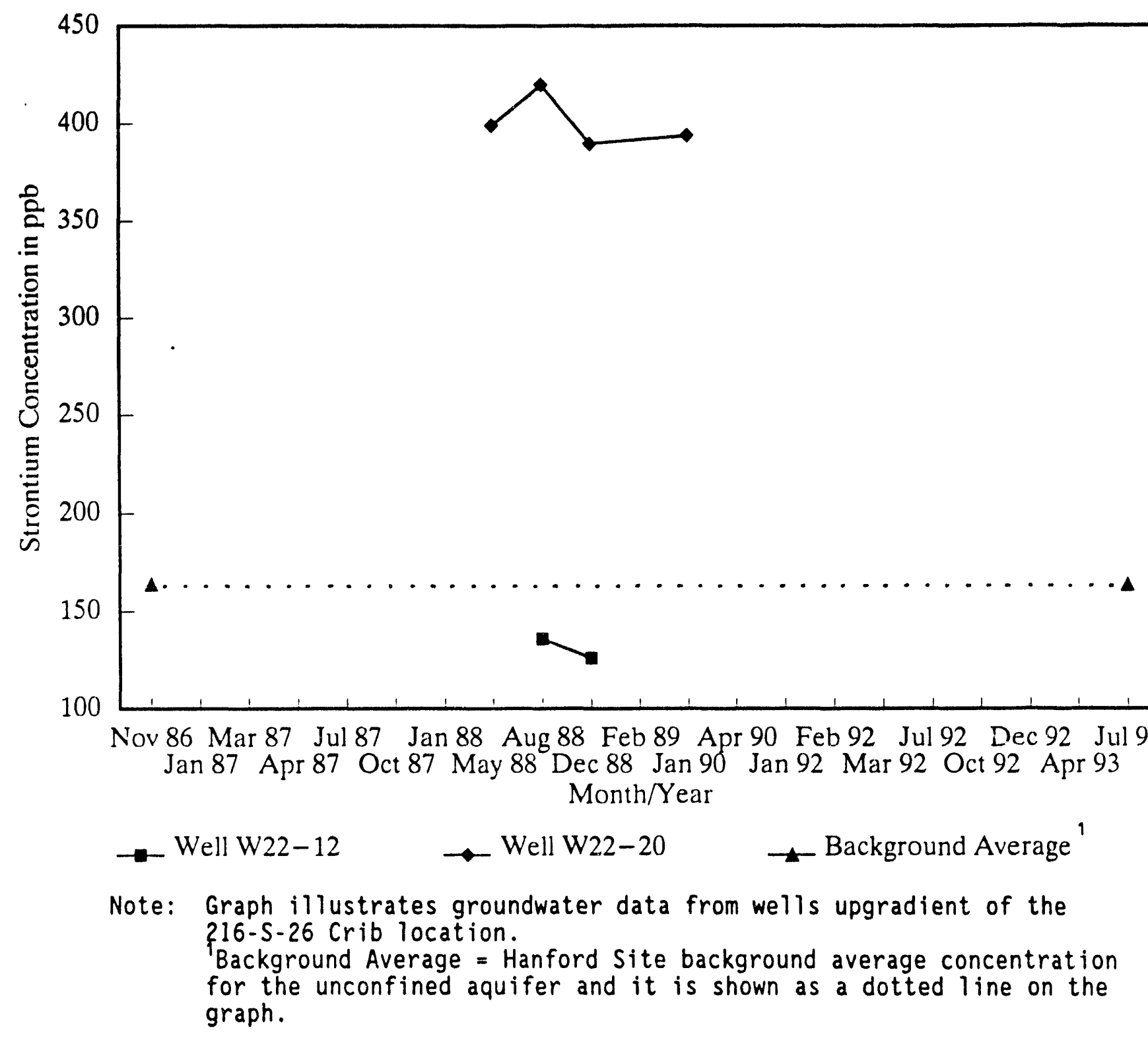




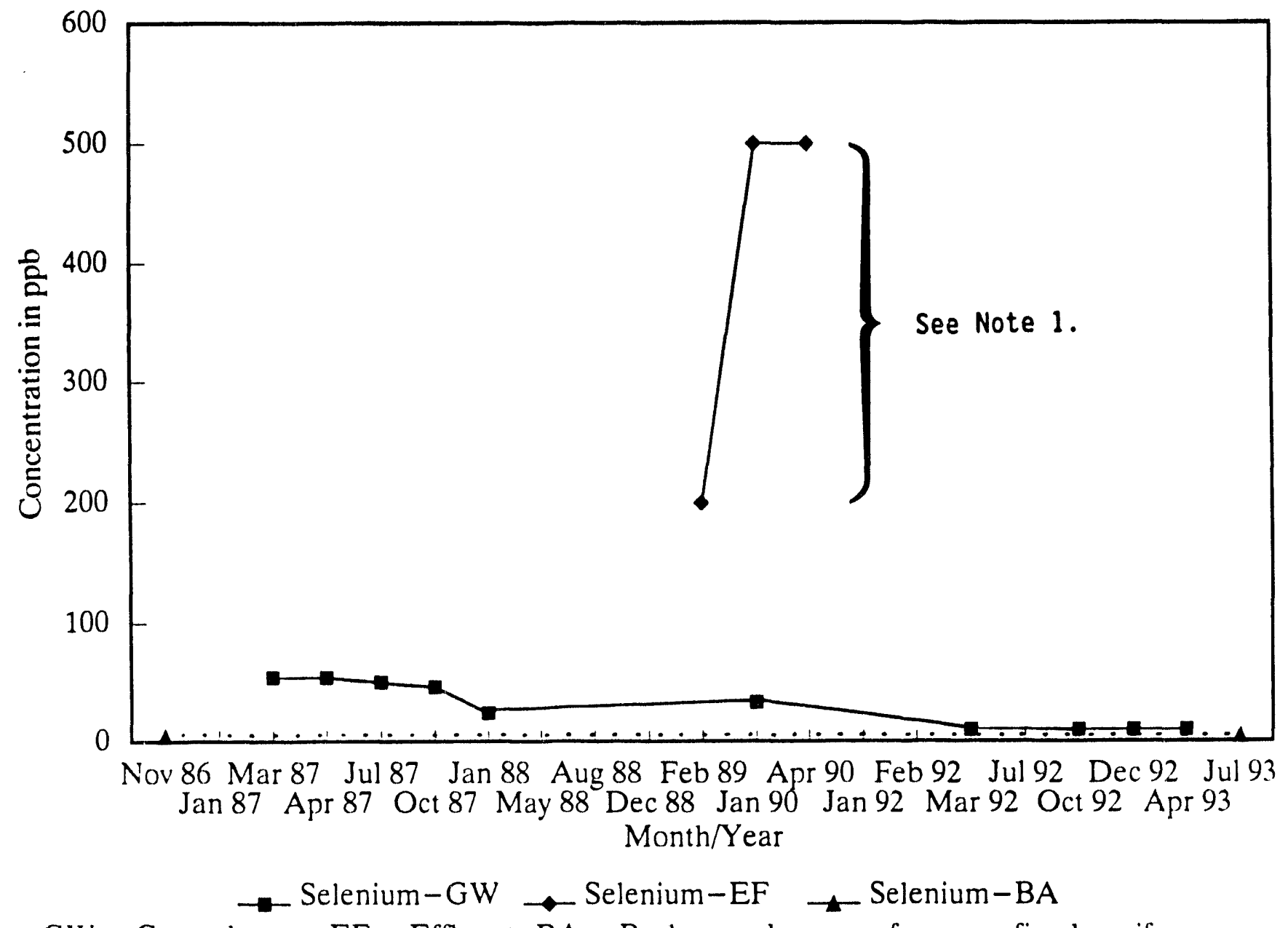

$\mathrm{GW}=$ Groundwater. $\mathrm{EF}=$ Effluent. $\mathrm{BA}=$ Background average for unconfined aquifer.

Note: 'Effluent analytical limit of detection (all three samples) is too high to determine if any selenium is present. 


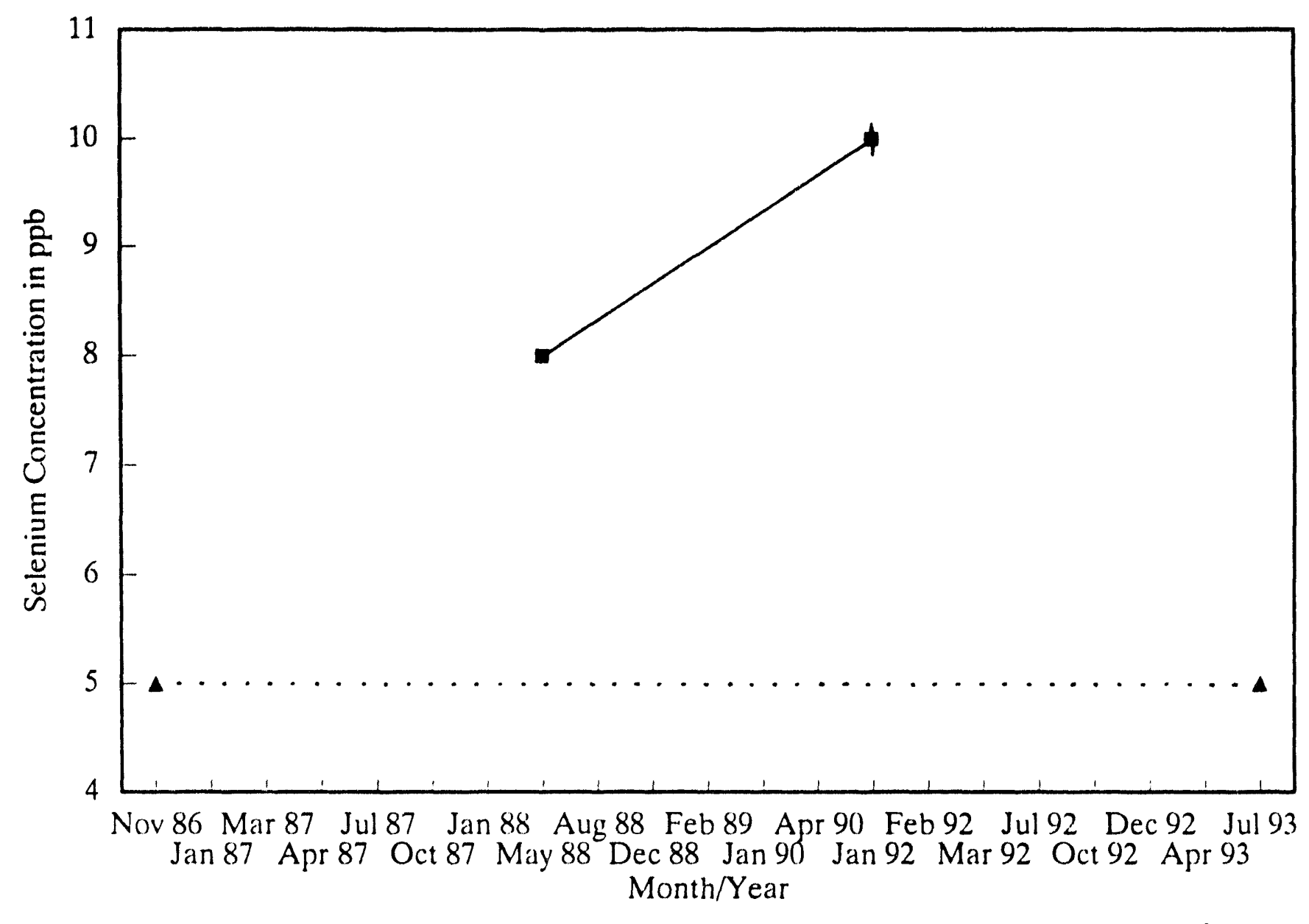

$\rightarrow$ Well W22-20 $\rightarrow$ Well W22-21 $\rightarrow$ Background Average ${ }^{\prime}$

Note: Graph illustrates groundwater data from wells upgradient of the 216-S-26 Crib location.

Background Average = Hanford Site background average concentration for the unconfined aquifer and it is shown as a dotted line on the graph. 


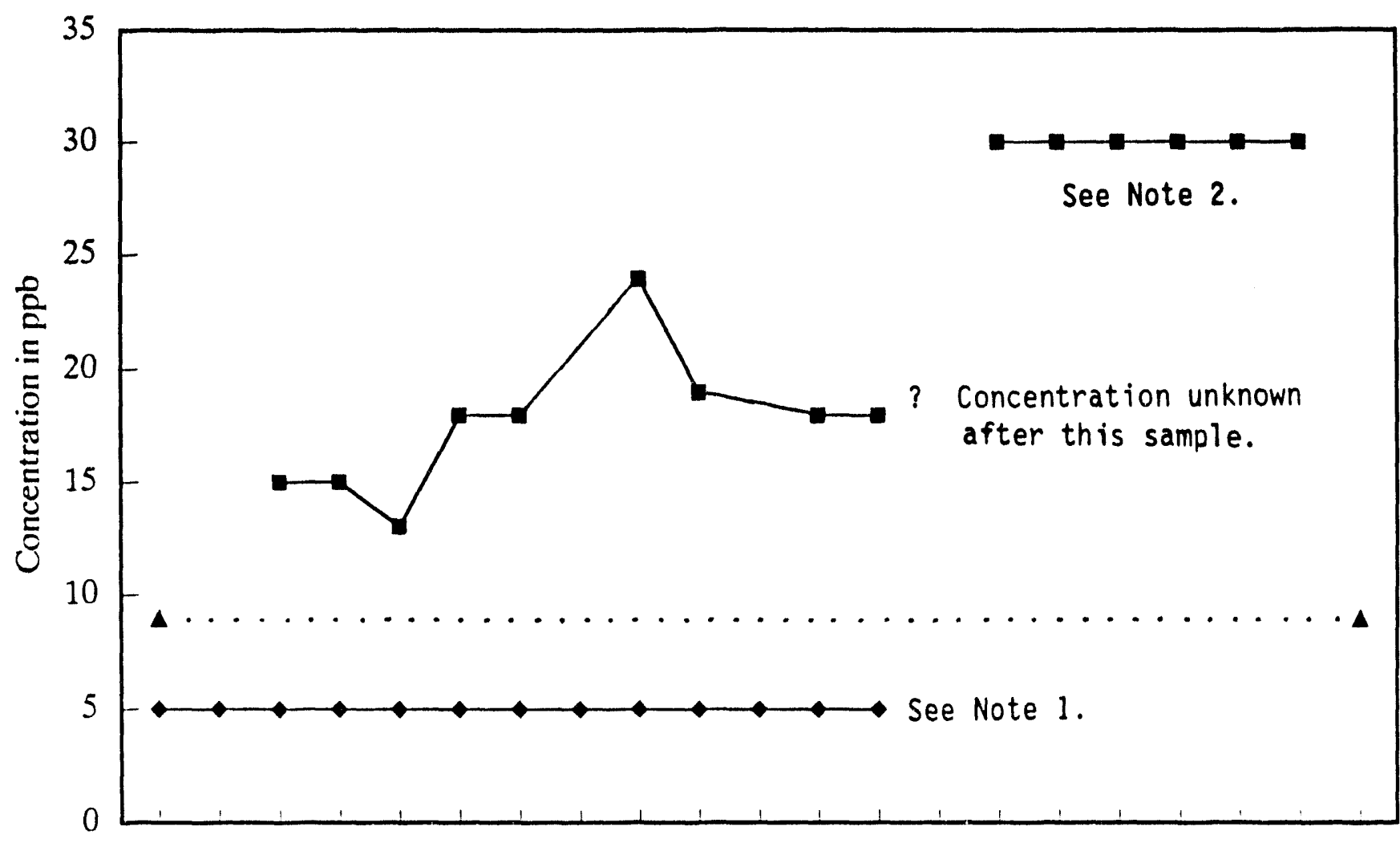

Nov 86 Mar 87 Jul 87 Jan 88 Aug 88 Feb 89 Apr 90 Feb 92 Jul 92 Dec 92 Jul 93 Jan 87 Apr 87 Oct 87 May 88 Dec 88 Jan 90 Jan 92 Mar 92 Oct 92 Apr 93 Month/Year

$\rightarrow$ Vanadium-GW $\rightarrow$ Vanadium-EF $\rightarrow$ Vanadium-BA

$\mathrm{GW}=$ Groundwater. $\mathrm{EF}=$ Effluent. $\mathrm{BA}=$ Background average for unconfined aquifer .

Note: 'Effluent vanadium concentration is less than the analytical limit of detection.

${ }^{2}$ Groundwater analytical limit of detection (starting January 1992) is too high to determine if any vanadium is present. 




Nov 86 Mar 87 Jul 87 Jan 88 Aug 88 Feb 89 Apr 90 Feb 92 Jul 92 Dec 92 Jul 93 Jan 87 Apr 87 Oct 87 May 88 Dec 88 Jan 90 Jan 92 Mar 92 Oct 92 Apr 93 Month/Year

$$
\begin{aligned}
& \rightarrow-\text { Well W22-12 } \rightarrow \text { Well W22-20 } \\
& \text { * Well W22-21 } \rightarrow \text { Background Average }{ }^{1}
\end{aligned}
$$

Note: Graph illustrates groundwater data from wells upgradient of the 216-S-26 Crib location.

Background Average $=$ Hanford Site background average concentration for the unconfined aquifer and it is shown as a dotted line on the graph. 


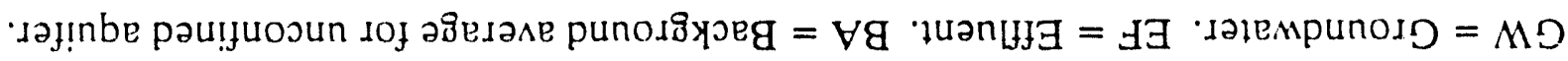

$$
\begin{gathered}
\forall G-\text { ou! } \rightarrow+ \\
\text { IRวN/41UOW }
\end{gathered}
$$

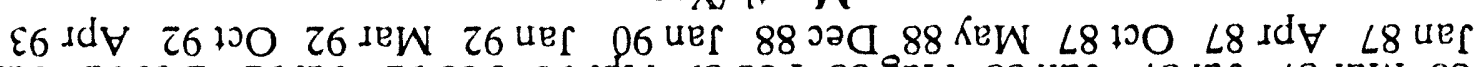

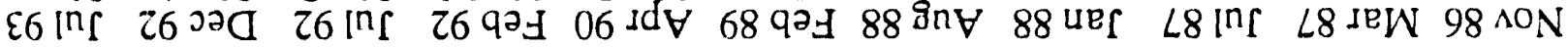






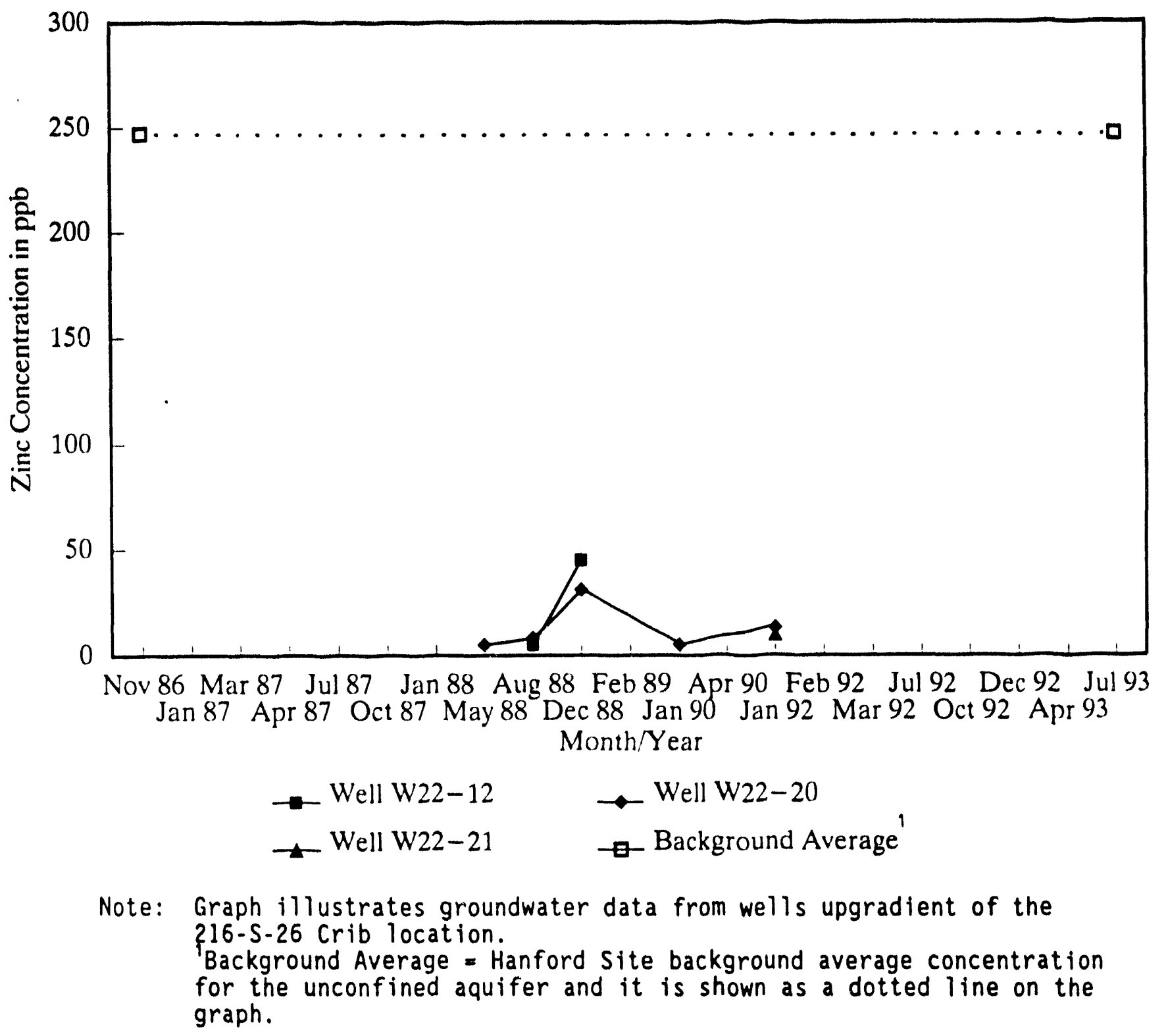


WHC-EP-0690

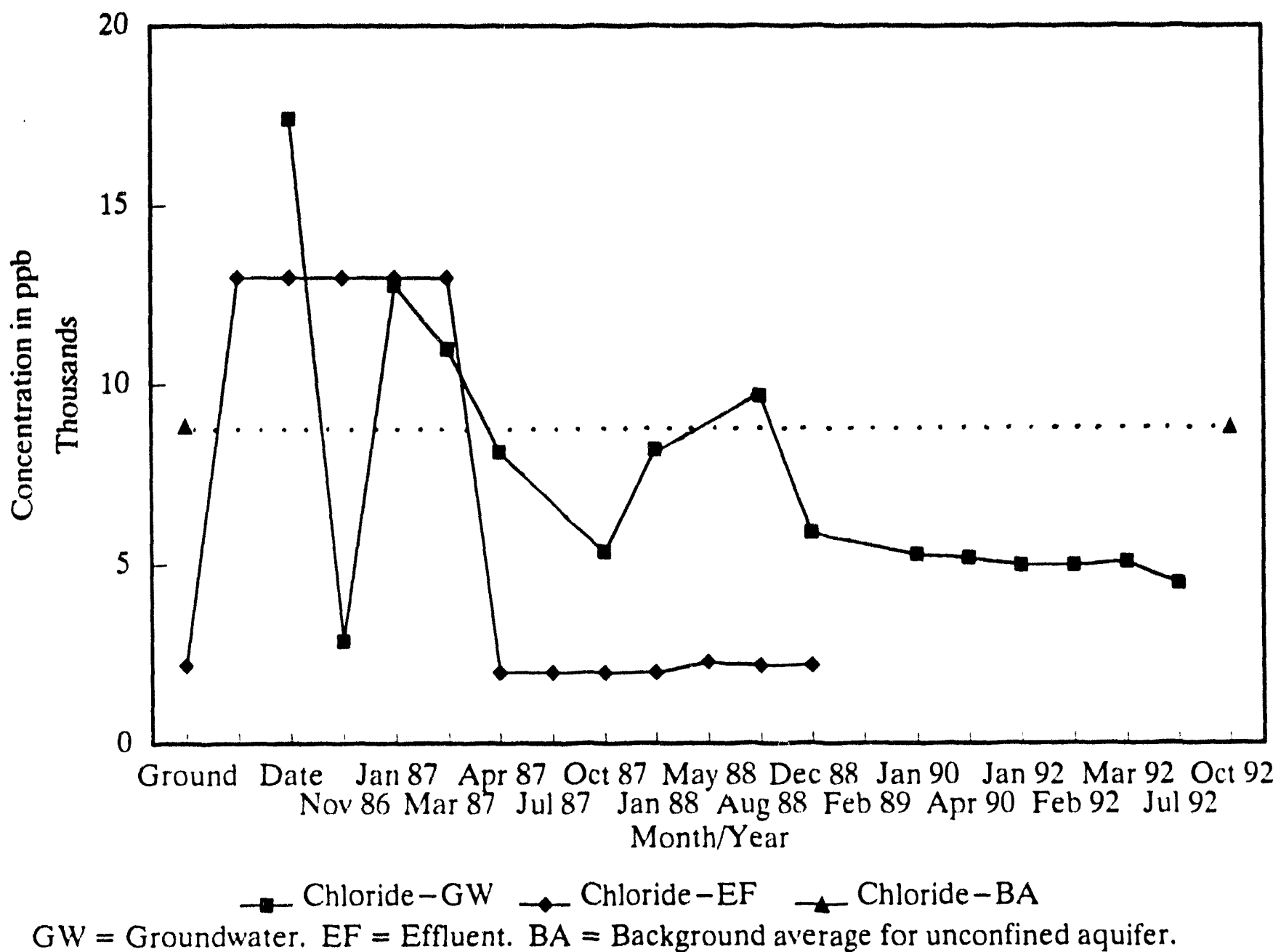




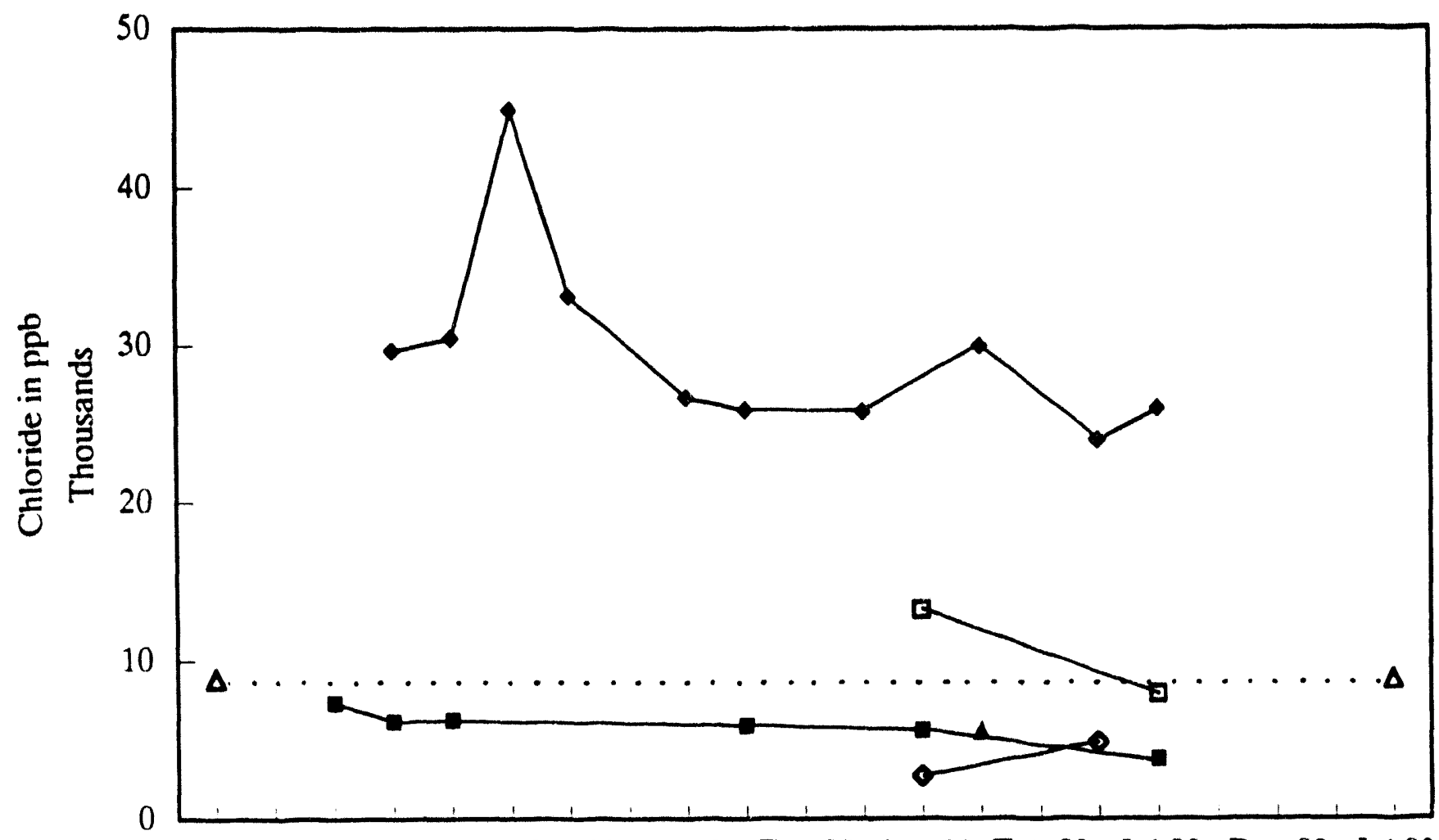

Nov 86 Mar 87 Jul 87 Jan 88 Aug 88 Feb 89 Apr 90 Feb 92 Jul 92 Dec 92 Jul 93 Jan 87 Apr 87 Oct 87 May 88 Dec 88 Jan 90 Jan 92 Mar 92 Oct 92 Apr 93 Month/Year

$\rightarrow$ Well W22-12

$\rightarrow$ Well W22-10 $\rightarrow$ Well W22-20

$\rightarrow$ Well W'23-9 $\rightarrow$ Well W22-21

$\triangle$ Background Average ${ }^{\prime}$

Note: Graph 117 ustrates groundwater data from wells upgradient of the 216-S-26 Crib location. Background Average = Hanford Site background average concentration for the unconfined aquifer and it is shown as a dotted line on the graph. 




$\mathrm{GW}=$ Groundwater. $\mathrm{EF}=$ Effluent. $\mathrm{BA}=$ Background average for unconfined aquifer. 


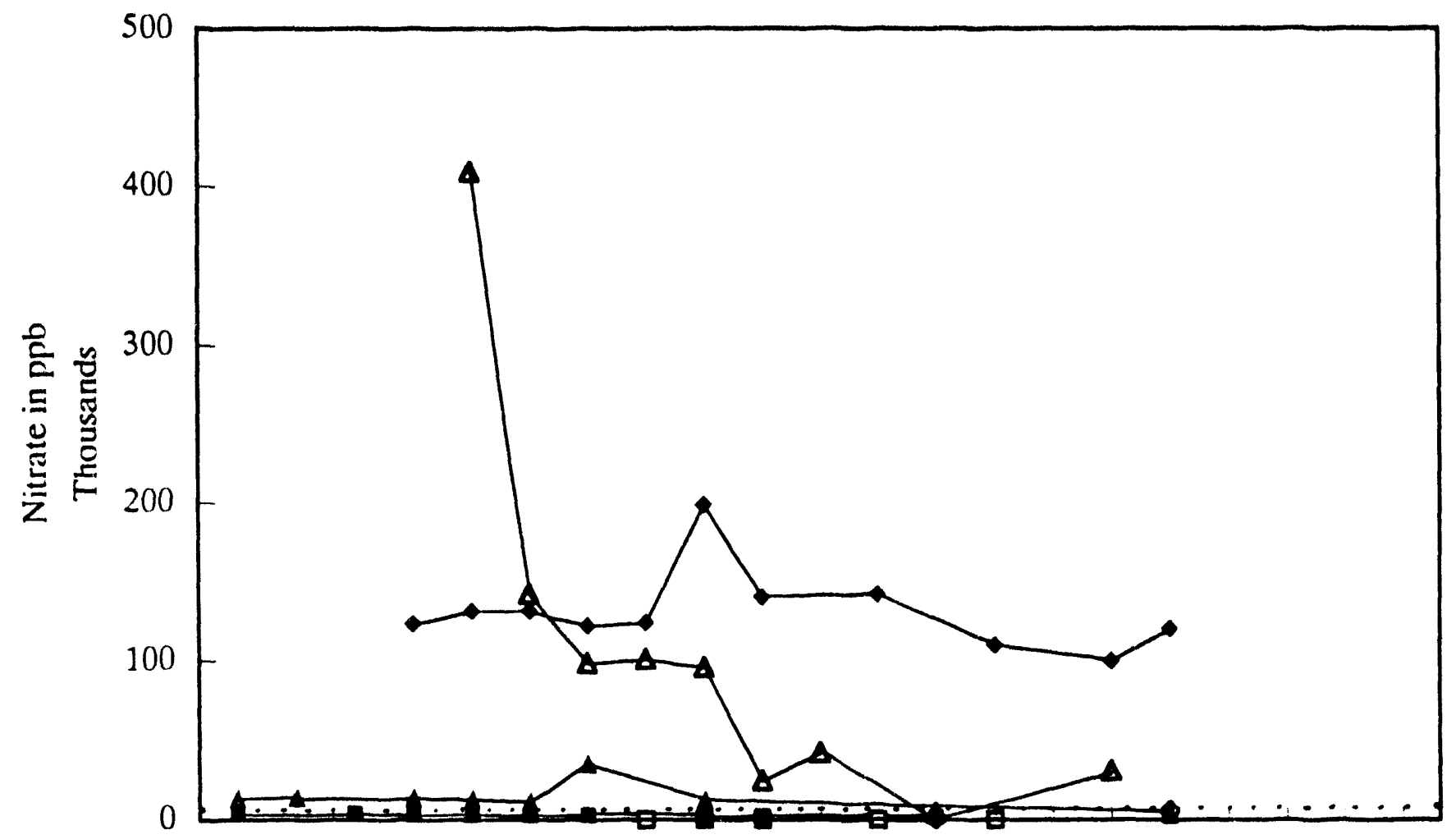

Nov 86 Mar 87 Jul 87 Jan 88 Aug 88 Feb 89 Apr 90 Feb 92 Jul 92 Dec 92 Jul 93 Jan 87 Apr 87 Oct 87 May 88 Dec 88 Jan 90 Jan 92 Mar 92 Oct 92 Apr 93 Month/Year

$\rightarrow-$ Well W22-12 $\rightarrow$ Well W22-20 $九$ Well W22-21

$\rightarrow$ Well W22-7 $\diamond$ Well W22-10 $₫$ Well W23-9

Note: Graph illustrates groundwater data from wells upgradient of the 216-5-26 Crib location.

Hanford Site background average concentration for the unconfined aquifer is shown as a dotted line. 
WHC-EP-0690



$\mathrm{GW}=$ Groundwater. $\mathrm{EF}=$ Effluent. $\mathrm{BA}=$ Background average for unconfined aquifer . 


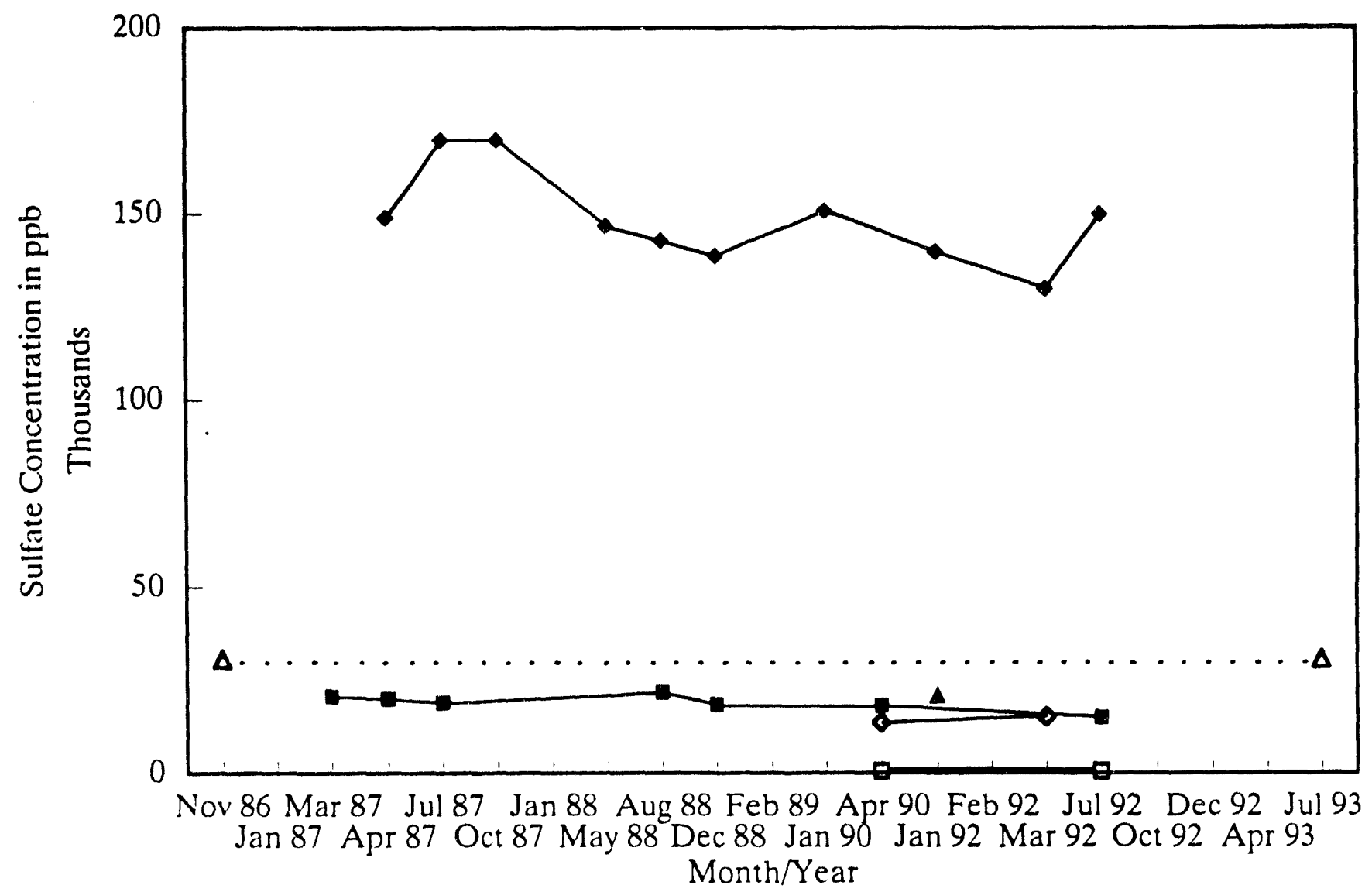

$\rightarrow$ Well W22-12

$\rightarrow$ Well W22-20

$\leftarrow$ Well W22-21

$\rightarrow$ Well W22-10

๑- Well W23-9

$\triangle$ Background Average '

Note: Graph illustrates groundwater data from wells upgradient of the 216-S-26 Crib location.

Background Average = Hanford Site background average concentration for the unconfined aquifer and it is shown as a dotted line on the graph. 


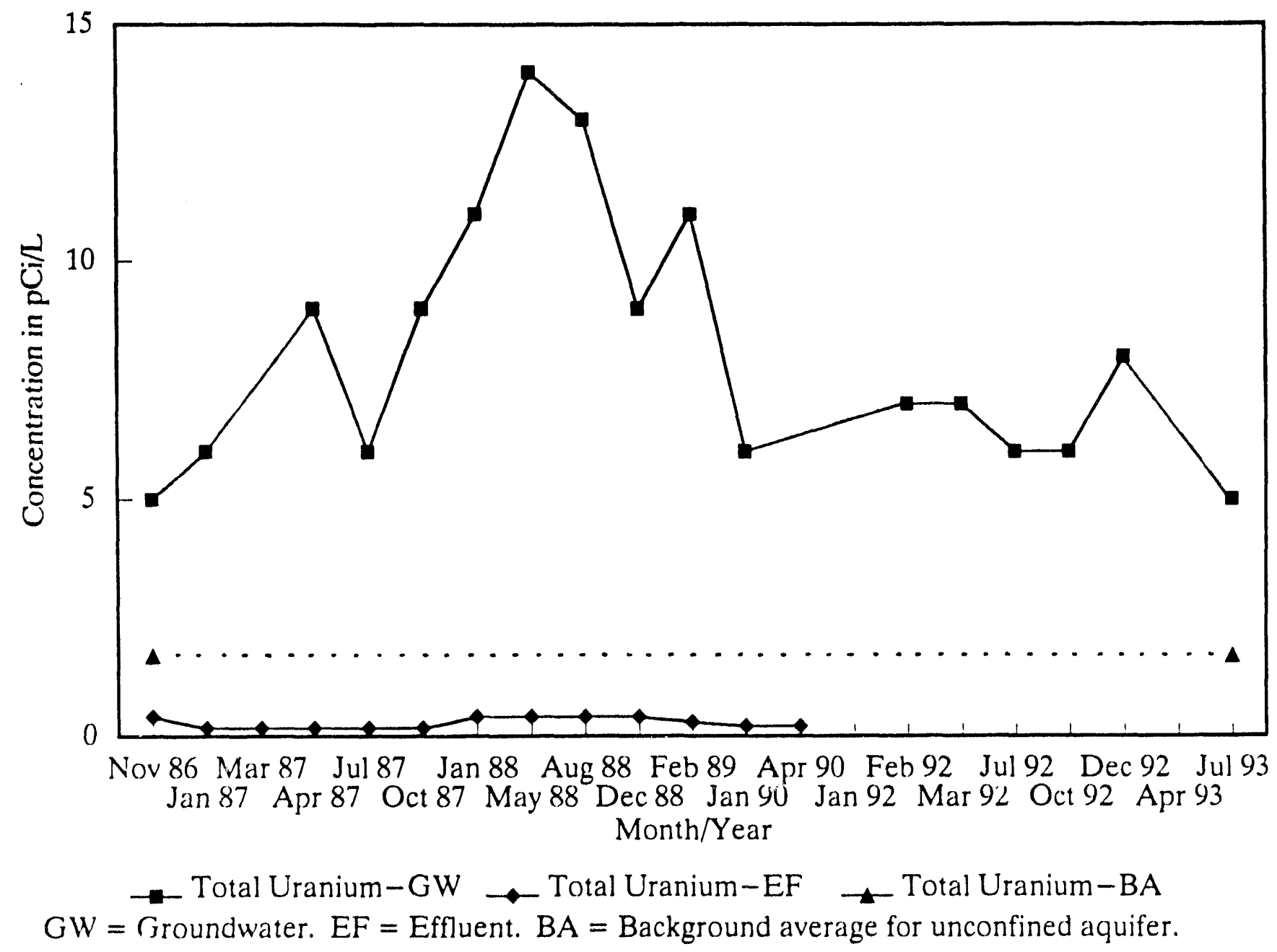






Nov 86 Mar 87 Jul 87 Jan 88 Aug 88 Feb 89 Apr 90 Feb 92 Jul 92 Dec 92 Jul 93 Jan 87 Apr 87 Oct 87 May 88 Dec 88 Jan 90 Jan 92 Mar 92 Oct 92 Apr 93 Month/Year

$\rightarrow$ Well W22-12 $\rightarrow$ Well W22-20 $\rightarrow$ Well W22-21

古 Well W22-7 ه- Well W22-10 $\rightarrow$ Well W23-9

Note: Graph illustrates groundwater data from wells upgradient of the 216-S-26 Crib location.

Hanford Site background average concentration for the unconfined aquifer is shown as a dotted line. 
WHC-EP-0690

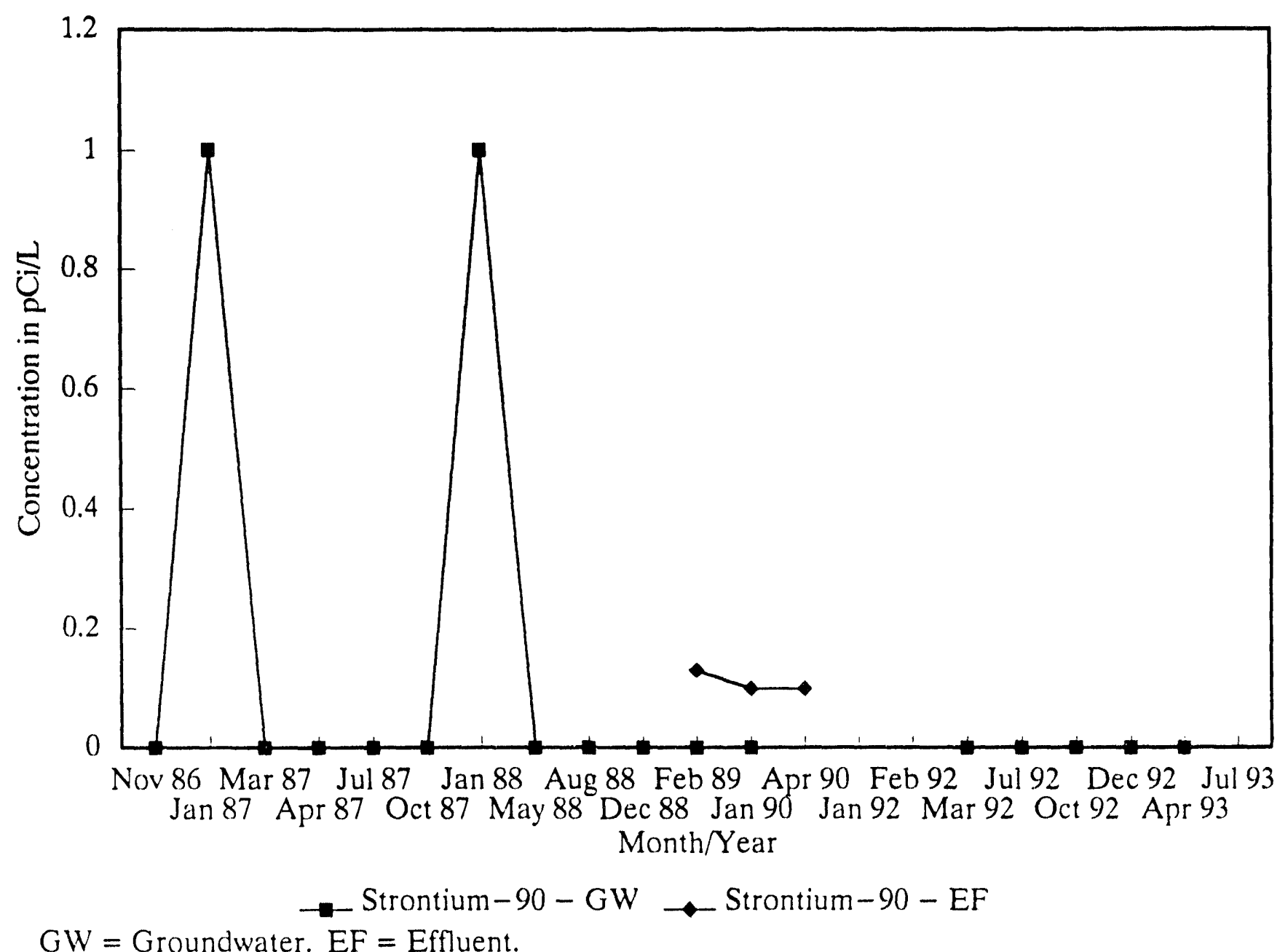




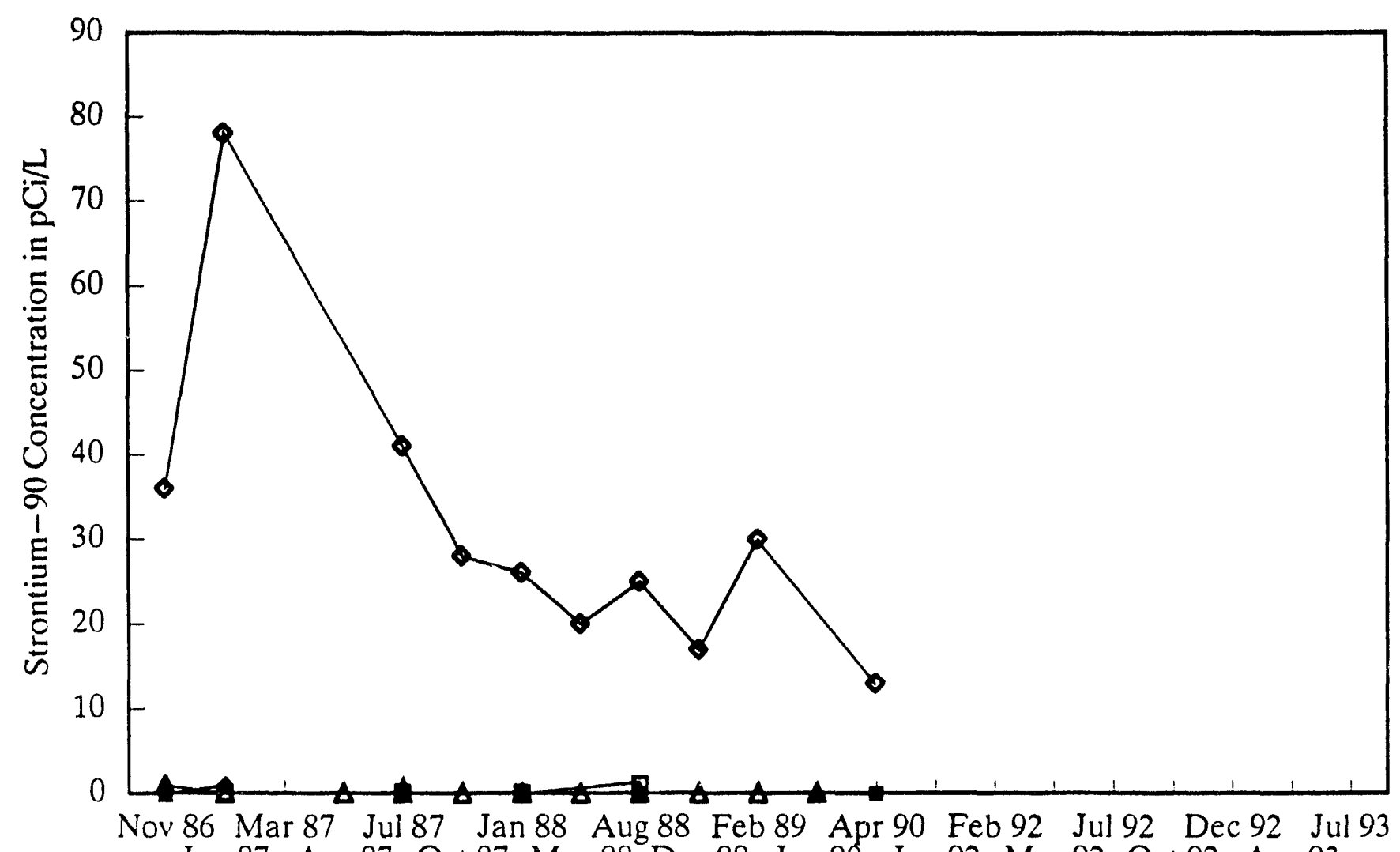

Jan 87 Apr 87 Oct 87 May 88 Dec 88 Jan 90 Jan 92 Mar 92 Oct 92 Apr 93 Month/Year

$\rightarrow$ Well W22-12 $\rightarrow$ Well W22-20 $九$ Well W22-21

$\rightarrow$ Well W22-7 $\rightarrow$ Well W22-10 $\triangle$ Well W23-9

Note: Graph illustrates groundwater data from wells upgradient of the 216-S-26 Crib location. 
WHC-EP-0690

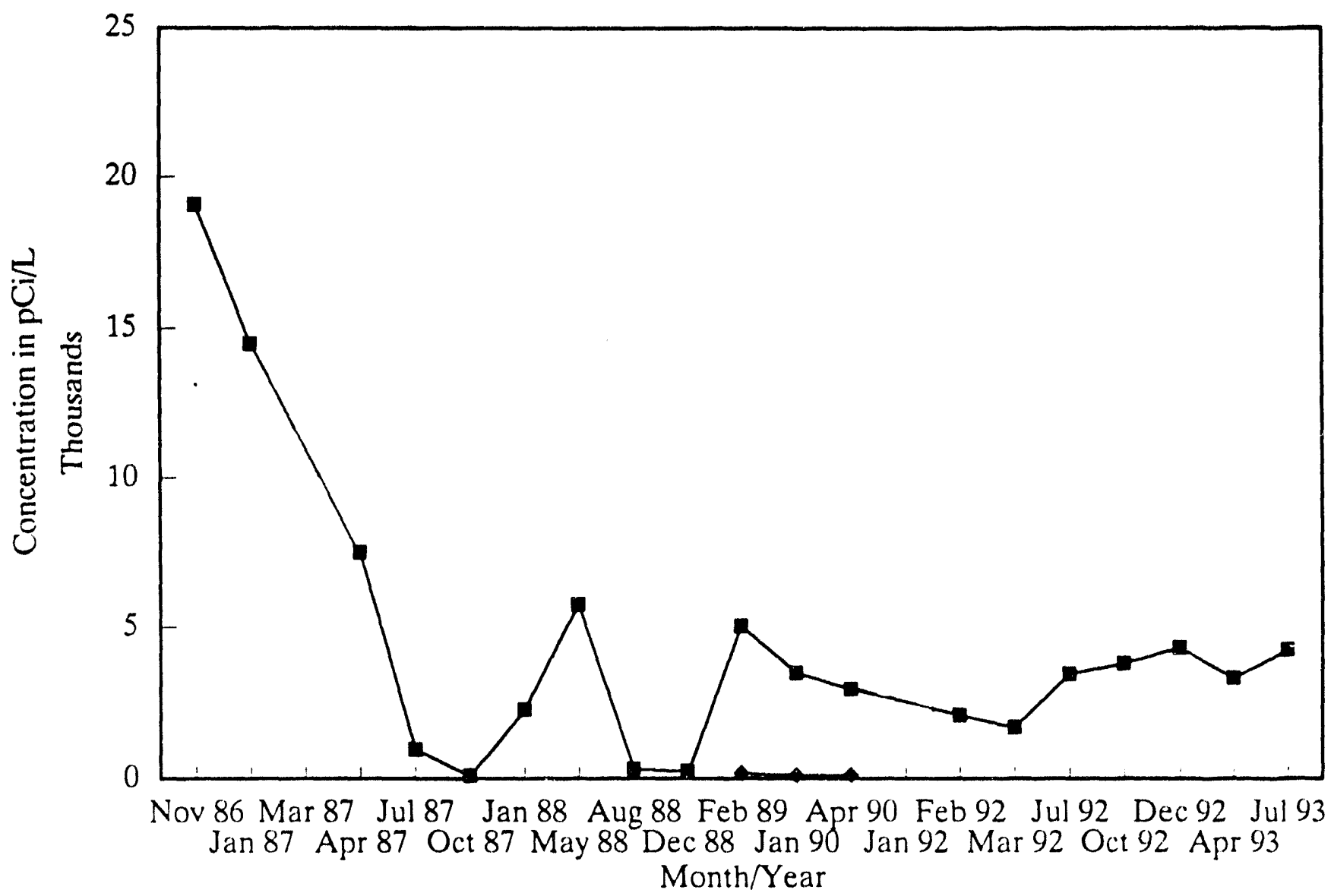

$\mathrm{GW}=$ Groundwater. $\mathrm{EF}=\overrightarrow{\mathrm{Effluent}}$. Tritium $-\mathrm{GW} \rightarrow$ Tritium $-\mathrm{EF}$ 


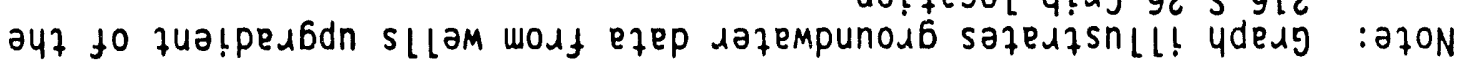

$$
\begin{aligned}
& 6-\varepsilon Z M\|\partial M \rightarrow 0 I-Z Z M\| \partial M-\sigma \quad L-Z Z M \| \partial M \rightarrow
\end{aligned}
$$

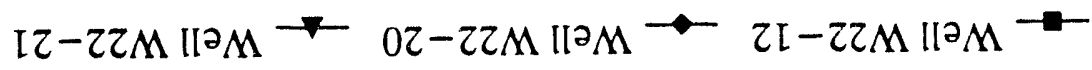

$$
\begin{aligned}
& \text { Iอ2 N/YIUOW }
\end{aligned}
$$

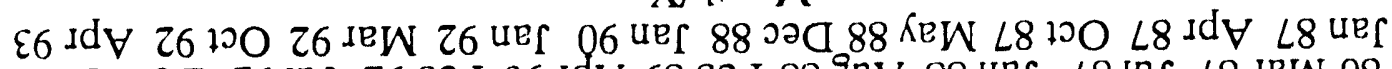



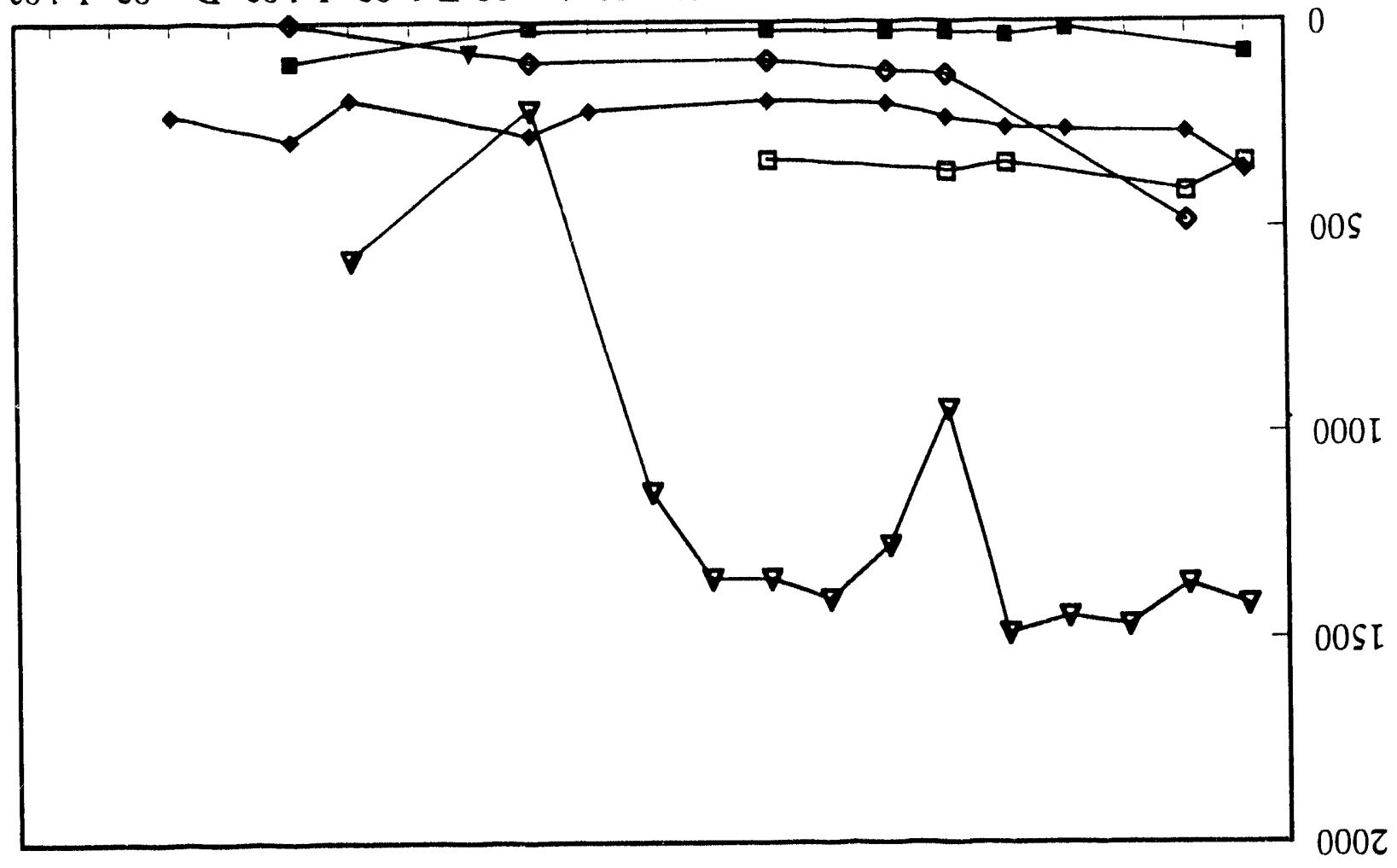


WHC-EP-0690

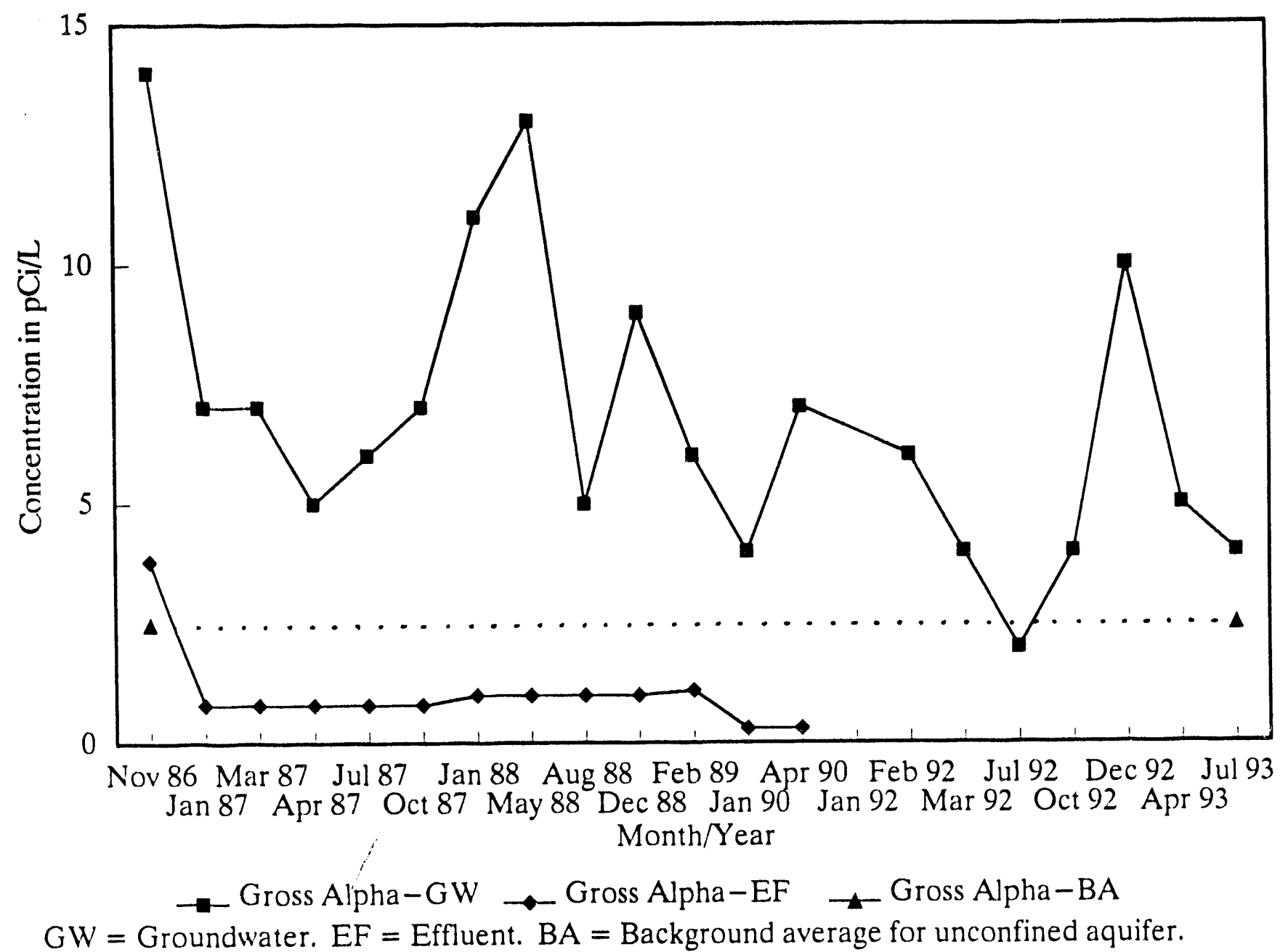






Nov 86 Mar 87 Jul 87 Jan 88 Aug 88 Feb 89 Apr 90 Feb 92 Jul 92 Dec 92 Jul 93 Jan 87 Apr 87 Oct 87 May 88 Dec 88 Jan 90 Jan 92 Mar 92 Oct 92 Apr 93 Month/Year

$$
\begin{array}{lll}
\rightarrow \text { Well W22-12 } & \rightarrow \text { Well W22-20 } & \rightarrow \text { Well W22-21 } \\
\rightarrow \text { Well W22-10 } & \sim \text { Well W23-9 } & \rightarrow \text { Background Average }
\end{array}
$$

Note: Graph illustrates groundwater data from wells upgradient of the 216-5-26 Crib location.

Background Average = Hanford Site background average concentration for the unconfined aquifer and it is shown as a dotted line on the graph. 


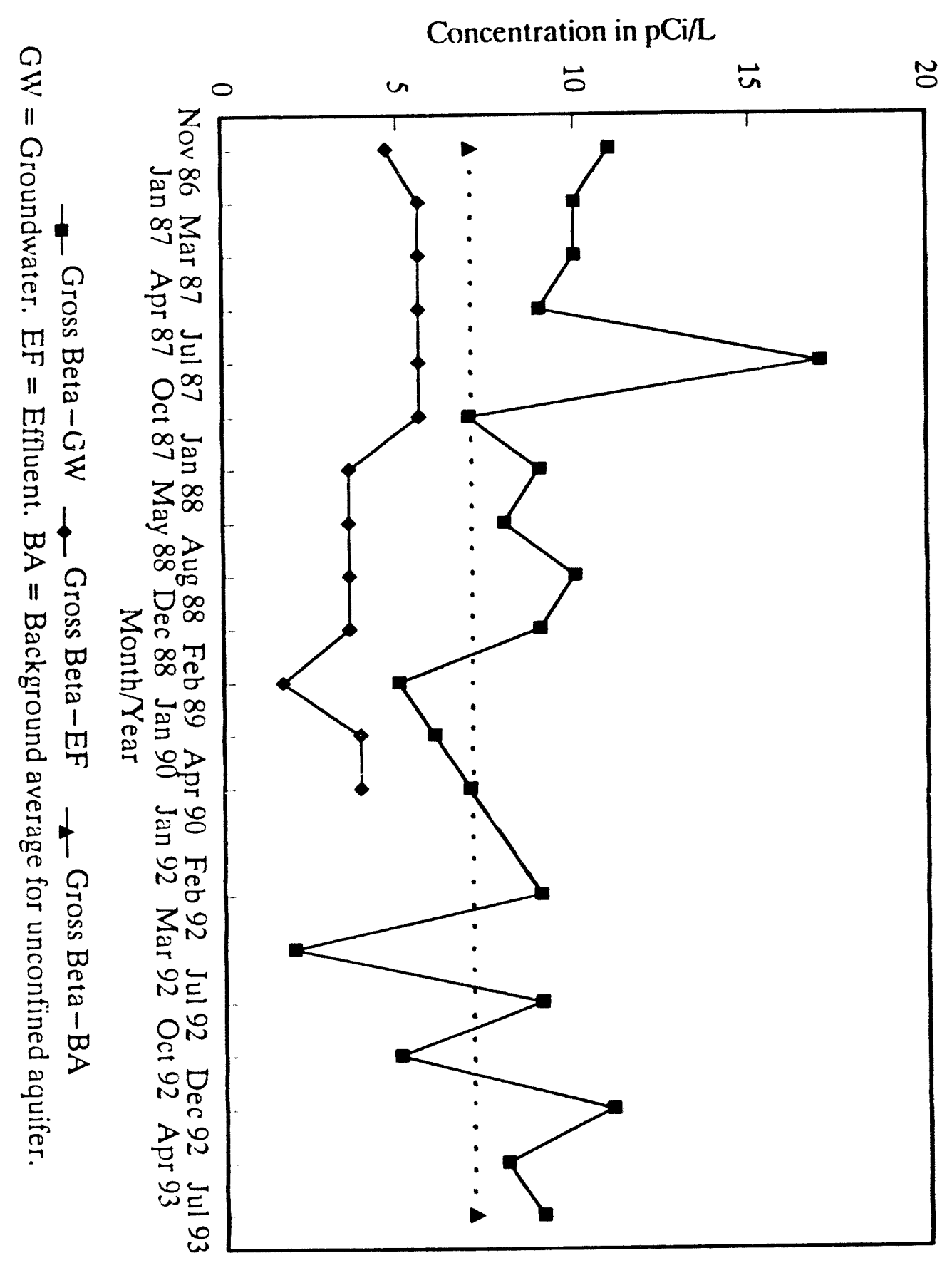

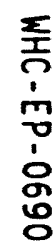




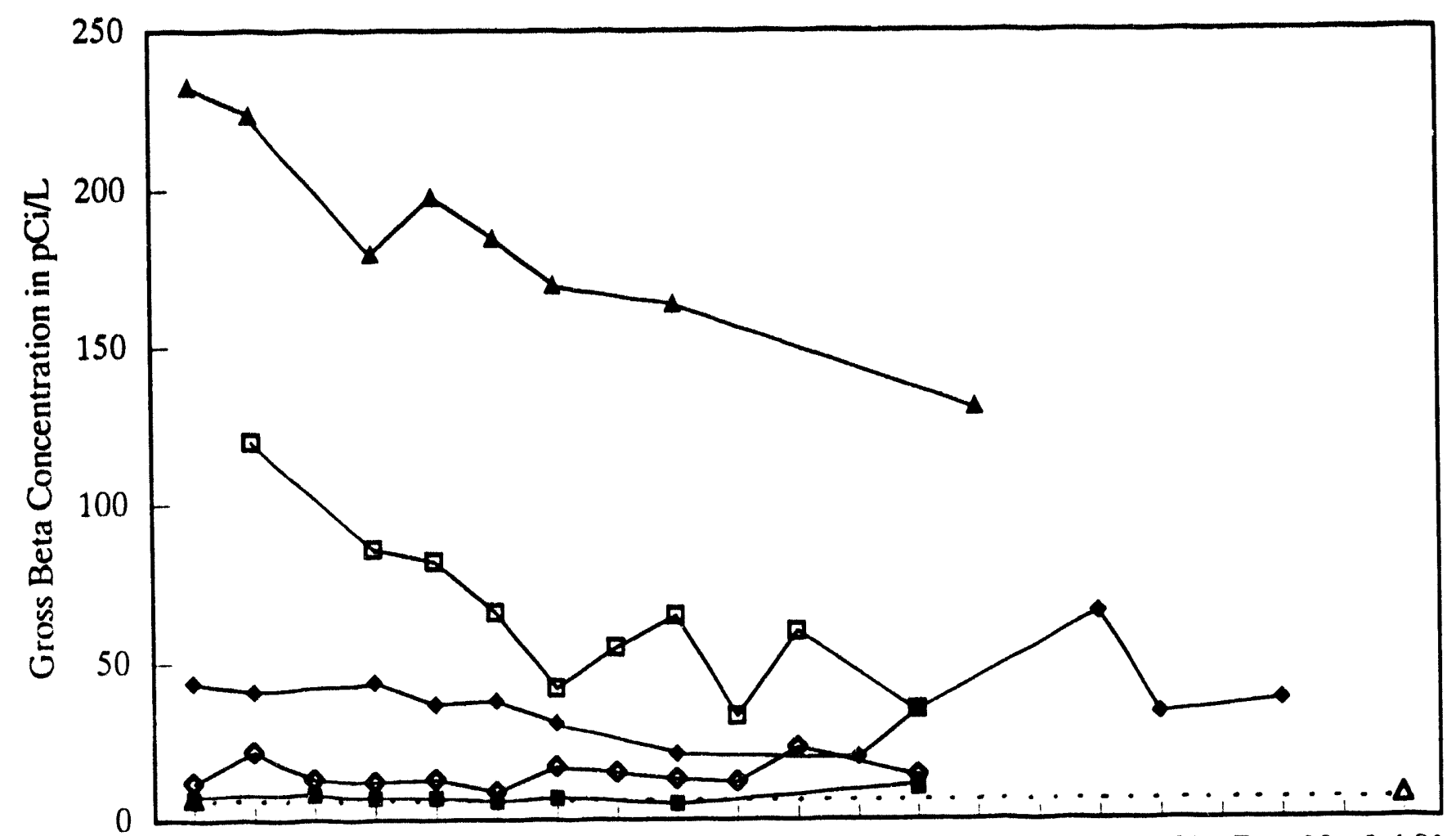

Nov 86 Mar 87 Jul 87 Jan 88 Aug 88 Feb 89 Apr 90 Feb 92 Jul 92 Dec 92 Jul 93 Jan 87 Apr 87 Oct 87 May 88 Dec 88 Jan 90 Jan 92 Mar 92 Oct 92 Apr 93 Month/Year

$\rightarrow$ Well W22-12

^ـWell W22-20

$\neg$ Well W22-21

$\rightarrow$ Well W22-10

$\rightarrow$ Well W23-9

$\triangle$ Background Average

Note: Graph illustrates groundwater data from wells upgradient of the 216-S-26 Crib location.

Background Average = Hanford Site background average concentration for the unconfined aquifer and it is shown as a dotted line on the graph. 
$0 b-8$

-yuela 7 tal Klleuolquaquf abed s\$4L

0690-d]-JHM 
WHC-EP-0690

DISTRIBUTION

Number of copies

\section{OFFSIIIE}

1

Southwest Research Institute

6220 Culebra Road

San Antonio, Texas 78284

B. Sagar

2

Confederated Tribes of the

Umatilla Reservation

P.0. Box 638

Pendleton, OR 97801

J. R. Wilkinson

2

Nez Perce Tribal Office

P. 0. Box 305

LaPwai, ID 83540

D. Powaukee

2

Yakima Indian Nation

2552 Haines

Richland, WA 99352

R. F. Cook

\section{ONSITE}

8

U.S. Department of Energy,

Richland Operations office

K. V. Clarke

A5-15

B. A. Davis

R3-82

M. J. Furman

R3-81

J. M. Hennig

R3-80

M. P. Johansen

A5-19

J. E. Rasmussen

A5-15

S. H. Wisness

A5-15

RL Public Reading Room

Al-65

1

Pacific Northwest Laboratory

PNL Technical files

K1-11

Distr-1 
WHC-EP-0690

DISTRIBUTION (cont.)

\section{Number of copies}

\section{ONSITE}

41

\section{Westinghouse Hanford Company}

D. J. Alexander (5)

Ho. $n$

L. E. Borneman

J. A. Caggiano

S. D. Evelo (5)

K. R. Fecht

B. H. Ford

G. 0. Gesell

D. G. Horton

V. G. Johnson

D. E. Kelley

A. J. Knepp

A. G. Law

J. W. Lindberg (5)

S. P. Reidel

K. M. Singleton

D. R. Speer

D. K. Tyler (3)

G. J. Warwick

Central Files

Document $\mathrm{Pr}$ and Dist

Environment.

\section{ig}

B2- 5

H6-06

H6-06

H6-06

H6-06

H6-31

H6-06

H6-06

R3-46

H6-06

H6-06

H6-06

H6-06

H6-06

R1-48

H6-06

T6-12

L8-04 Information Release

Administration

L8-15

H6-08

Ł8-07 

